UNIVERSIDADE DE SÃO PAULO

FACULDADE DE FILOSOFIA, LETRAS E CIÊNCIAS HUMANAS DEPARTAMENTO DE LETRAS MODERNAS

ÁREA DE LÍNGUA, LITERATURA E CULTURA ITALIANAS

ERICA APARECIDA SALATINI MAFFIA

ENTRE A INCERTEZA DO SENTIDO E OS EQUÍVOCOS DA EXPERIÊNCIA:

UMA LEITURA DOS CONTOS DE ANTONIO

TABUCCHI.

SÃO PAULO

2014. 


\section{ENTRE A INCERTEZA DO SENTIDO E OS EQUÍVOCOS DA EXPERIÊNCIA: UMA LEITURA DOS CONTOS DE ANTONIO TABUCCHI.}

Tese apresentada ao Programa de Pós-Graduação em Língua, Literatura e Cultura Italianas do Departamento de Letras Modernas da Faculdade de Filosofia, Letras e Ciências Humanas da Universidade de São Paulo para obtenção do título de Doutor em Língua, Literatura e Cultura Italianas.

Área de concentração: Língua, Literatura e Cultura Italianas.

Orientador: Profa. Dra. Roberta Barni

São Paulo

2014 
AUTORIZO A REPRODUÇÃO E DIVULGAÇÃO TOTAL OU PARCIAL DESTE

TRABALHO, POR QUALQUER MEIO CONVENCIONAL OU ELETRÔNICO, PARA FINS DE ESTUDO E PESQUISA, DESDE QUE CITADA A FONTE.

\section{Catalogação na Publicação}

\section{Serviço de Biblioteca e Documentação}

Faculdade de Filosofia, Letras e Ciências Humanas da Universidade de São Paulo

M187 Maffia, Erica Aparecida Salatini

Entre a incerteza do sentido e os equívocos da

experiência: uma leitura dos contos de Antonio Tabucchi

/ Erica Aparecida Salatini Maffia ;

orientadora Roberta Barni. - São Paulo, 2014.

$166 \mathrm{f}$.

Tese (Doutorado)- Faculdade de Filosofia, Letras e Ciências Humanas da Universidade de São Paulo. Departamento de Letras Modernas. Área de concentração: Língua, Literatura e Cultura Italiana.

1. Literatura Italiana Contemporânea. 2. Pósmodernidade.

I. Barni, Roberta, orient. II. Título. 


\section{DEDICATÓRIA}

àquela que partiu...

e àquele que vai chegar... 


\section{AGRADECIMENTOS}

À Capes pela concessão de uma Bolsa de Estudos que me pertmitiu realizar esta pesquisa.

À Profa. Dra. Roberta Barni pelo apoio e pelas leituras.

À Profa. Dra. Lucia Wataghin, que me convidou a participar do grupo de pesquisa Literatura Italiana Traduzida no Sistema Nacional, o que me possibilitou um amadurecimento intelectual.

Aos membros do grupo de pesquisa Literatura Italiana Traduzida no Sistema Nacional, companheiros de pesquisa e de animadas reuniões.

Ao Francisco Degani, pela ajuda na revisão e na tradução de alguns trechos.

Ao meu marido Gesualdo e à minha filha Manuela, pelo incentivo e pela paciência. 


\title{
RESUMO
}

O livro de contos Il gioco del rovescio, do escritor italiano Antonio Tabucchi, publicado em 1981, marca o início de uma poética, segundo o autor. Com o título de "poetica dei buchi”, Tabucchi propõe uma literatura fragmentária, com uma predileção pelos vazios, pela construção narrativa a partir destes "buracos" e fissuras, por histórias incompletas. Esta poética é reafirmada e acrescida de pequenas nuances em Piccoli equivoci senza importanza e L'Angelo Nero, coletâneas de contos publicadas respectivamente em 1985 e 1991. Neste trabalho, procuramos analisar estas obras discutindo alguns de seus temas e procedimentos estruturais, verificando sua recorrência e procurando dialogar com concepções teóricas ligadas à pós-modernidade literária.

Palavras-chave: Antonio Tabucchi, narrativa contemporânea, pós-modernidade.

\begin{abstract}
The collection Il gioco del rovescio, of the italian writer Antonio Tabucchi, published in 1981, marks, according to the author, the beginning of a poetics. With the title "poetica dei buchi", Tabucchi suggests a fragmented literature, that shows a preference for empty, for narrative constructions starting from these "buchi" and fissures, for incompleted stories. That poetics is reaffirmed and strengthened by subtle nuances in Piccoli equivoci senza importanza and L'Angelo Nero, collections of stories published in 1985 and in 1991. In this work, we try to analyze these collections, discussing some of their themes and structural processes, verifying their recurrence and trying to dialogue with the theoretical conceptions related to postmodernity in literature.
\end{abstract}

Key-words: Antonio Tabucchi, contemporary fiction, postmodernity. 


\section{RIASSUNTO}

La raccolta Il gioco del rovescio, dello scrittore italiano Antonio Tabucchi, pubblicata nel 1981, segna, secondo l'autore, l'inizio di una poetica. Con il titolo di "poetica dei buchi", Tabucchi propone una letteratura frammentata, che manifesta una preferenza per i vuoti, per la costruzione narrativa a partire da questi "buchi”" e fessure, per storie incomplete. Questa poetica è riaffermata e rafforzata da piccole sfumature in Piccoli equivoci senza importanza e L'Angelo Nero, raccolte di racconti pubblicate rispettivamente nel 1985 e nel 1991. In questo studio, cerchiamo di analizzare queste opere, discutendo alcuni dei loro temi e procedimenti strutturali, verificandone la ricorrenza e cercando di dialogare con concezioni teoriche legate alla post-modernità letteraria.

Parole-chiave: Antonio Tabucchi, narrativa contemporanea, post-modernità. 


\section{ENTRE A INCERTEZA DO SENTIDO E OS EQUÍVOCOS DA EXPERIÊNCIA: UMA LEITURA DOS CONTOS DE ANTONIO TABUCCHI.}




\section{SUMÁRIO}



1.1. A NARRATIVA DE ANTONIO TABUCCHI: UMA BREVE APRESENTAÇÃO................................................................................................18

2. IL GIOCO DEL ROVESCIO: NOTAS PARA UMA POÉTICA............ 32

2.1. A POÉTICA “DEI BUCHI" E A CONSTRUÇÃO DO PERSONAGEM





2.3. O TEMPO REVERSÍVEL DA MEMÓRIA............................................. 45

2.4. IL NESSO FRA LE COSE: OS SUBTEXTOS NARRATIVOS............... 56

3. PICCOLI EQUIVOCI E O ENIGMA DO REAL..................................... 64

3.1. O UNIVERSO LITERÁRIO COMO ENIGMA E/OU EQUÍVOCO..... 64

3.2. IL GIALLO: DEFINIÇÃO DA FUNÇÃO INVESTIGATIVA DA

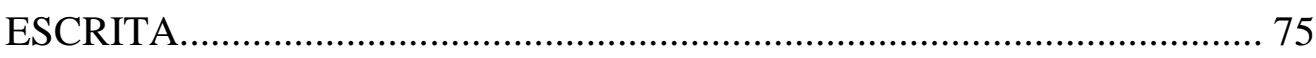

3.3. L'APPUNTAMENTO MANCATO …………………………………... 86

3.4. INTERTEXTUALIDADE E AUTORREFERENCIALIDADE EM "I TRENI CHE VANNO A MADRAS"........................................................ 96

4. L'ANGELO NERO E A FICCIONALIZAÇÃO DA HISTÓRIA.........104

3.1. DIÁLOGO ENTRE LITERATURA E HISTÓRIA................................ 104

3.2. OS ANOS DE CHUMBO NA ITÁLIA E A IMPLICAÇÕES IDEOLÓGICAS DO ATO DE ESCREVER SOBRE A HISTÓRIA..............108 3.3. NATUREZA INTERTEXTUAL DO PASSADO E PROBLEMATIZAÇÃO DO CONHECIMENTO HISTÓRICO: O SALAZARISMO EM PORTUGAL.......................................................... 118

3.4. PRESENÇA MALÉFICAS EM L'ANGELO NERO.............................. 132

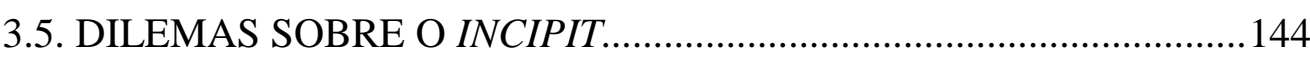

CONSIDERAÇÕES FINAIS ..........................................................................150

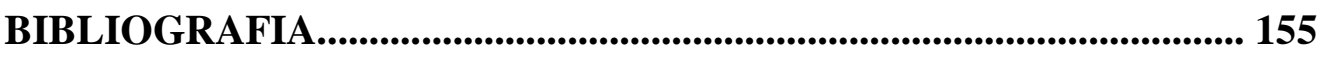




\section{INTRODUÇÃO}

O escritor Antonio Tabucchi, falecido recentemente, em março de 2012, pode ser considerado um dos escritores mais importantes da literatura contemporânea italiana. O autor recebeu vários prêmios pela sua obra, em especial pelo romance Sostiene Pereira. Foi traduzido em 18 idiomas, inclusive em português, língua que conhecia muito bem, e com a qual nutria fortes relações, tendo sido professor de Língua e Literatura Portuguesas nas Universidades de Gênova e de Siena. Também foi tradutor do português para o italiano, e traduziu obras dos poetas Fernando Pessoa e Alexandre O’Neill, amigo pessoal do autor, além de traduzir um livro do brasileiro Carlos Drummond de Andrade.

No Brasil, grande parte de sua obra narrativa se encontra traduzida. A primeira tradução de que temos notícias data de 1991, quase dezesseis anos após a estréia de Tabucchi como autor, em 1975. Esta consiste na tradução da novela Notturno indiano, de 1984, uma das obras que tornou o escritor célebre, seja por ter recebido o prêmio francês Médicis étranger, em 1987, seja pelo filme de Alain Corneau, de 1989. Noturno indiano, traduzida pelo professor Wander Mello Miranda, foi publicada a primeira vez pela Editora Rocco, a principal difusora das obras do autor no país até o início dos anos 2000.

Em 1994, Mário Fondelli traduziu L'Angelo Nero - Anjo negro, a quarta coletânea de contos do escritor, publicada na Itália em 1991. Esta ficou famosa por recolher um polêmico conto do autor, "Il battere d'ali di una farfalla a New York può provocare un tifone a Pechino?", que entrou nos autos do processo de apelação do caso Adriano Sofri, acusado de ser o mandante do homicídio do comissário Calabresi. Com esta narrativa, Tabucchi foi acusado pelo juiz responsável de tentar influenciar o "êxito do processo".

O romance mais famoso do autor, Sostiene Pereira, lançado na Itália em 1994, foi traduzido no Brasil logo depois, em 1995, quando o autor já gozava de certo prestígio internacional e já havia recebido os prêmios italianos Campiello e Viareggio. Afirma Pereira: um testemunho foi traduzido pela professora Roberta Barni, e dela são 
também as traduções de Gli ultimi tre giorni di Fernando Pessoa: un delirio, de 1994, que recebe o título em português $O s$ três últimos dias de Fernando Pessoa: um delírio, publicado em 1996, e La testa perduta di Damasceno Monteiro, de 1997, traduzido logo em seguida, em 1998, com o título A cabeça perdida de Damasceno Monteiro.

Podemos notar que a partir de Sostiene Pereira, as traduções de Tabucchi ganham uma assiduidade maior no cenário nacional, sendo suas obras traduzidas quase que imediatamente após o lançamento italiano. Este é o caso, sobretudo, do romance $A$ cabeça perdida de Damasceno Monteiro, narrativa policial bastante popular, com uma temática e uma escrita mais acessível, que conquista, inclusive, o público jovem.

Na década de 1990, devido à repercussão internacional da obra de Tabucchi, o leitor brasileiro pode conhecer não só os romances mais famosos, como também sua narrativa mais peculiar e característica, por meio de traduções de diversos especialistas. A Editora Rocco publica Sogni di sogni (1992) - Sonhos de sonhos e Donna di Porto Pim (1983) - Mulher de Porto Pim, obras particulares na ampla gama de prosas do autor, ambas com tradução de Rachel Gutiérrez, publicadas respectivamente em 1996 e 1999. Já I volatili del Beato Angelico (1987) - Os Voláteis do Beato Angélico, publicado em 2003, e Si sta facendo sempre più tardi (2001) - Está ficando tarde demais: romance em forma de cartas, em 2004, foram traduzidos por Ana Lúcia R. Belardinelli. A Rocco publicou ainda, em 2001, Requiem, livro escrito diretamente em português pelo autor, em 1991, além de uma tradução portuguesa de Tristano morre, feita por Gaëtan Martins de Oliveira, em 2007. A obra original italiana foi publicada em 2004.

A partir de 2010, a narrativa tabucchiana passa a ser publicada pela Editora paulistana Cosac Naify, que reedita Noturno indiano e Afirma Pereira, respectivamente em 2012 e 2013. A única nova tradução publicada pela editora é a do livro de contos $I l$ tempo invecchia in fretta. Nove storie, de 2009, lançado no Brasil com o título O tempo envelhece depressa: nove histórias, em 2010, com a tradução de Nilson Moulin.

Restam várias obras ainda por traduzir, entre estas, dois dos livros de contos utilizados no corpus deste trabalho, Il gioco del rovescio e Piccoli equivoci senza importanza. Estas duas coletâneas são muito importantes na configuração da poética de Tabucchi, pois originam temáticas e procedimentos estruturais, que servirão de base à escrita de suas narrativas posteriores. 
Como representante da literatura contemporânea italiana, a narrativa de Tabucchi se torna notória por tratar de temas que são universais, por dialogar com várias culturas, por meio da presença de personagens que viajam por terras distantes, como a Índia, os Açores, passando por vários pontos da Europa, em especial por Portugal, cenário de dois romances do autor e de diversos contos. Some-se a essa presença portuguesa na literatura de Tabucchi, a figura do poeta Fernando Pessoa, que se torna personagem de novelas, contos e de um drama do autor, além de objeto de estudo de sua obra crítica.

Considerada em seu aspecto formal e metaliterário, a literatura de Tabucchi postula algumas concepções e modos de construção literários que são muito produtivos para a reflexão e o estudo geral da literatura contemporânea, em especial dos temas e procedimentos considerados pós-modernos pela crítica especializada. É este modo de fazer tabucchiano que procuramos investigar neste trabalho de pesquisa, ou seja, o modo de construção de uma literatura autônoma e reflexiva, além da utilização de técnicas e procedimentos que configuram uma poética.

Para isso, nos detivemos no estudo crítico da narrativa breve de Tabucchi, mais especificamente de três coletâneas de contos publicados no período literário que vai de 1981 a 1991, o que inclui seu primeiro volume de contos, Il gioco del rovescio (1981), Piccoli equivoci senza importanza (1985) e L'Angelo Nero (1991). O recorte se justifica se considerarmos que este período, para o autor, é de afirmação de uma poética tanto quanto de uma concepção de literatura: a chamada poética "dei buchi”, em que o autor lança mão de histórias incompletas de personagens desbotados, que não são mais que sombras e aparições que se impõem à imaginação. Deixamos de lado Donna di Porto Pim (1983) e I volatili del Beato Angelico (1987), narrativas breves que foram publicadas no período em questão, mas que, como dissemos, são particulares no âmbito da prosa do autor, não sendo necessariamente definidas como "contos".

No que se refere à perspectiva crítica adotada por este trabalho, procuramos abordar a literatura de Antonio Tabucchi de um ponto de vista temático, analisando, quando necessário, as questões estruturais a ele relacionados. Isto porque, não obstante o instrumental analítico fortemente assentado em uma concepção pós-moderna de literatura, tivemos a oportunidade de verificar, com esta pesquisa, que não existe um consenso entre a crítica do autor, seja ela italiana ou não, em considerar Tabucchi "pós- 
moderno". Remo Ceserani, por exemplo, é um dos críticos a investigar a temática pósmoderna na obra de Tabucchi. Respondendo à questão se existiria uma representação do pós-moderno na literatura italiana, Ceserani nota que há diversos exemplos, mas acrescenta que

\begin{abstract}
"la letteratura ha i suoi tempi e le sue sfasature. La cultura italiana e le sue istituzioni letterarie hanno reso difficile l'esplorazione dei temi postmoderni e delle nuove modalità rappresentative; le poetiche di gran parte dei produttori di testi letterari, quelle dei redattori di case editrici, quelle dei recensori dei giornali, per esempio, sono fondate sul criterio, e il rispetto quasi religioso, della soluzione stilistica individuale" ${ }^{1}$.
\end{abstract}

Diante da nova forma de "manipulação estilística do pós-moderno", grande parte da crítica, permanecendo ligada à ideia de literatura como representação realista da vida ou como "fato expressivo e de estilo", reagiu dizendo que esta forma "não era literatura". Por este motivo, afirma Ceserani, quando a "nova lógica cultural" e o pósmoderno apareceram na Itália, com um material temático novo e especial, com novos problemas epistemológicos, com uma tendência a se afastar de todos os códigos e modelos estilísticos, a jogar e manipular com estes modelos, tudo pareceu à crítica uma situação literária já vivida e desgastada pelo “espressionismo italiano”, corrente da literatura de vanguarda da primeira metade do século XX.

Ceserani insiste no fato que a falta de um estilo nas obras pós-modernas e a tendência a misturar e manipular os estilos é o que explica esta rejeição da crítica italiana à literatura pós-moderna. Não obstante esta experiência de recusa da crítica, Ceserani aponta para ao menos três autores que, guardadas as devidas diferenças, podem ser representantes do pós-moderno na Itália: Calvino, Eco e Tabucchi.

Para Ceserani, Tabucchi é um dos mais “dotados, refinados e renomados” entre os escritores italianos que podem ser considerados representantes da literatura pósmoderna, sendo possível reconhecer algumas das características típicas da pósmodernidade literária na sua produção narrativa:

\footnotetext{
${ }^{1}$ Ceserani, R. Raccontare il postmoderno. Turim: Bollati Boringhieri Editore, 1997. p. 164: "a literatura tem seu tempo e seus descompassos. A cultura italiana e suas instituições literárias dificultaram a exploração dos temas pós-modernos e das novas modalidades representativas; as poéticas de grande parte dos produtores de textos literários, aquelas dos redatores de editoras, aquelas dos resenhistas dos jornais, por exemplo, são fundadas no critério e no respeito quase religioso da solução estilística individual". Trad. nossa. A partir deste ponto, quando não houver indicação expressa do tradutor, o texto traduzido deve ser entendido como de nossa autoria.
} 


\begin{abstract}
"Il tema della personalità doppia o ambigua; l'esperienza della disperazione o della solitudine (nella versione portoghese della saudade); l'importanza e la presenza ossessiva e perturbante del sogno; la rievocazione ripetuta e nostalgica di alcune plaghe e immagini cariche di memoria letteraria; l'uso di trame aperte, che restano alla fine in sospeso e senza completamento o chiusura (...); l'evocazione nostalgica di alcuni periodi della storia italiana recente; l'indebolimento infine e la moltiplicazione del soggetto"'2.
\end{abstract}

Em relação à técnica narrativa, Ceserani faz notar o uso frequente da colagem ou montagem; da intertextualidade, seja através da citação e do fragmento, seja através da revisitação paródica e do pastiche; da inserção de outras artes no texto literário, como a referência à música e ao cinema; da desmontagem e reconstituição da narrativa, entre outros procedimentos apontados pelo crítico.

Flavia Brizio-Skov, em Antonio Tabucchi: navigazioni in un arcipelago narrativo, também sustenta que a obra narrativa de Tabucchi, quando tenta inverter as relações entre o real e o fictício, para demonstrar que não se pode conhecer a realidade, opera com a problemática do pós-moderno. Brizio-Skov afirma que a narrativa de Tabucchi é pós-moderna porque está assentada na negação da existência de uma realidade unívoca, baseada em "regole conoscibili e categorie di tempo e spazio fisse, mostrando che la realtà è mutevole, polisemica, quindi inconoscibile nella sua totalità" ${ }^{3}$. Brizio-Skov mostra ainda que certos temas e modos narrativos de Tabucchi adquirem uma função e um sentido que não podem mais ser lidos a partir da ideia de modernidade.

Já para Monica Jansen, outra estudiosa do debate pós-moderno italiano, Tabucchi poderia ser considerado um "moderno pós-moderno" que tenta elaborar o "luto do moderno", já que o escritor retoma em sua obra, modernistas como Fernando

\footnotetext{
${ }^{2}$ Ceserani, R. Raccontare il postmoderno. cit. p. 202-3: "O tema da personalidade dupla ou ambígua; a experiência do desespero ou da solidão (na versão portuguesa da saudade); a importância e a presença obsessiva e perturbadora do sonho; a evocação repetitiva e nostálgica de algumas regiões e imagens carregadas de memória literária; o uso de tramas abertas, que permanecem em suspenso no final, e sem fechamento e conclusão (...); a evocação nostálgica de alguns períodos da história italiana recente; por fim, o enfraquecimento e a multiplicação do sujeito".

${ }^{3}$ Brizio-Skov, "Dai racconti a Notturno Indiano: 'gioco del rovescio', rebus, equivoci, mistero, intertestualità e percorsi incongrui". In: Antonio Tabucchi: navigazioni in un arcipelago narrativo. Cosenza: Pellegrini Editore, 2002. p. 103: "regras cognoscíveis e categorias de tempo e espaço fixas, mostrando que a realidade é mutável, polissêmica, portanto, incognoscível na sua totalidade".
} 
Pessoa, inserindo-o numa arte da "contaminação", na qual coexistem a aceitação da "herança" e o distanciamento desta herança através da ironia e da distorção ${ }^{4}$.

Já na leitura crítica de Anna Dolfi ${ }^{5}$, a obra de Tabucchi estaria muito mais relacionada à ótica do moderno do que à do pós-moderno. Dolfi trabalha com a poética da "inquietudine" - do desassossego - na obra de Tabucchi, tema que ela considera eminentemente moderno, e investiga como este tema se relaciona à questão da identidade e do duplo. Aponta também para os confins entre sonho e delírio, para o tema da culpa e do remorso, temas que são lidos a partir de um referencial teórico amplo, fazendo uso do instrumental psicanalítico freudiano e do confronto intertextual de obras da literatura italiana, sejam elas modernas ou pós-modernas.

Na mesma esteira, Nives Trentini afirma que a narrativa de Tabucchi é uma narrativa que sabe ser "nova e original", sem recorrer a estruturas de tipo "fantástico ou pós-moderno", e que Tabucchi usa conscientemente expedientes literários que tentam "maiuscolizzare la banalità", tornando extraordinário o quotidiano que a literatura coloca em cena ${ }^{6}$. Em Una scrittura in partita doppia, Trentini trabalha, entretanto, com uma perspectiva interessante para os estudos sobre a pós-modernidade na obra de Tabucchi. Investigando sua obra narrativa, a estudiosa aponta para duas fases importantes da obra de Tabucchi: uma primeira que vai de 1981, com a publicação de $I l$ gioco del rovescio, até a publicação de Requiem, em 1992. Nesta fase, ela aponta para a presença obsessiva do sonho, considerando que toda a obra narrativa deste período caminha em direção a uma espécie de "centro onírico". Centro este que é alcançado justamente com a publicação de Requiem, narrativa fantástica em que mortos e vivos se encontram no plano da "alucinação" do protagonista que é leitor, sonhador e narrador ao mesmo tempo. A outra fase se inicia com a publicação de Sostiene Pereira, em 1994, e estaria centrada em uma busca em direção ao real, em que Tabucchi se debruça sobre o desafio de lidar com a realidade política e social.

Outros estudiosos também apontam para esta divisão da obra de Tabucchi, mas o que interessa particularmente nos estudos de Trentini é a discussão sobre o "onirismo metaliterário", pois o lado onírico é aquele mais propenso a subverter a ordem das coisas, a instaurar o avesso e o equívoco, a exaltar a esfera da multiplicidade e a fazer

\footnotetext{
${ }^{4}$ Jansen, M. Il dibattito sul postmoderno in Italia. In bilico tra dialettica e ambiguità. Florença: Franco Cesati Editore, 2002. pp. 297 e ss.

${ }^{5}$ Dolfi, Anna. Tabucchi: la specularità, il rimorso. Roma: Bulzoni Editore, 2006.

${ }^{6}$ Trentini, Nives. Una scrittura in partita doppia. Tabucchi fra romanzo e racconto. Roma: Bulzoni Editore, 2003. pp. 40 e ss: "maiusculizar a banalidade".
} 
com que as fronteiras entre real e irreal se confundam ou se anulem ${ }^{7}$. Temas nos quais nos detivemos com maior frequência. Como vimos, para Ceserani, todavia, esta presença obsessiva e perturbante do sonho, consiste em um procedimento formal que pode ser assinalado como pós-moderno.

Uma questão bastante discutida pela crítica e que procuramos abordar neste trabalho, é a relação que Tabucchi estabelece com a noção de realidade, ou como notam alguns de seus estudiosos, a da frágil distinção que o autor estabelece entre realidade e ficção. Considerando que Tabucchi é um escritor "herdeiro" de uma tradição italiana de "realismos", uma literatura que questione as fronteiras entre história e ficção, entre sonho e vigília, entre real e fictício, questiona, também, as bases da noção de realidade e problematiza o modelo da visão realista da representação, ao mesmo tempo em que se utiliza criticamente e parodisticamente desta tradição.

A nosso ver, a narrativa tabucchiana, como herdeira desta tradição, possui uma forte base realista e se utiliza criticamente dela, parodiando-a e subvertendo-a por meio de seus temas e procedimentos, e nisso se torna eminentemente pós-moderna. Para Linda Huctheon ${ }^{8}$, por exemplo, a noção de realidade histórica e sua relação com a escrita literária na pós-modernidade passa necessariamente por uma consciência crítica dessa relação, confrontada pelos autores pós-modernos de modo irônico.

Já para Maria Corti, a noção de "real", presente na literatura italiana do final do milênio, parece estar assentada em uma visão do real como um conjunto de coisas orientadas em direção ao futuro, fusão de previsível e imprevisível, que não sabemos por qual caminho irá, com uma hipotética e maior densidade informativa. Diante deste tipo de caracterização do real, existe uma legalidade conceitual que não se pode ignorar, fazendo com que o escritor observador se discipline conceitualmente, evitando toda forma de reducionismo da realidade sob pena de perder a visão autêntica, naturalmente dramática da existência humana ${ }^{9}$.

Desta forma, mais que tentar discutir se Tabucchi é ou não um escritor pósmoderno, este trabalho procurou dialogar com estes temas, utilizando-se dos estudos críticos e teóricos acima elencados, para pensar como a obra do escritor italiano se

\footnotetext{
${ }^{7}$ Trentini, N. Una scrittura in partita doppia. cit., 2003. pp. 40 e ss.

${ }^{8}$ Hutcheon, Linda. Poética do Pós-Modernismo: história, teoria, ficção. Trad. Ricardo Cruz. Rio de Janeiro: Imago Ed. 1991.

${ }^{9}$ Corti, M. "Reale e realismi". In: Letteratura italiana del novecento. Bilancio di un secolo. Org. Alberto Asor Rosa. Turim: Einaudi, 2000.
} 
inscreve na contemporaneidade, como dialoga com seu tempo e sua história. Procuramos discutir como o autor representa esse diálogo em sua narrativa e como apresenta uma concepção peculiar de literatura e de fazer poético, que torna sua obra particular no âmbito da literatura contemporânea italiana, e mesmo universal.

Assim, no capítulo sobre Il gioco del rovescio, abordamos a temática da presença recorrente do sonho, da imaginação e da fantasia como formas de subversão e fuga da realidade, além de tentar mostrar como este livro preanuncia uma poética que será reelaborada constantemente pelo autor em suas obras sucessivas. O equívoco, o engano e o desejo de reversibilidade do tempo como formas de escapar da lógica do real, que parece inverossímil aos personagens e narradores tabucchianos, são os temas trabalhados no capítulo sobre Piccoli equivoci senza importanza. Tabucchi constrói a sua narrativa a partir de equívocos que engendram um falso sentido para o texto, ou uma pista falsa para a sua interpretação. De fato, a interpretação do sentido parece interessar menos ao autor que se detém em condensar a trama principal em uma história subentendida, secundária, não revelada, mas apenas insinuada, a ponto de gerar uma percepção errada e uma distorção do sentido, o que, por sua vez, resulta em núcleo temático. Neste capítulo, também procuramos nos deter na análise dos procedimentos estruturais relacionados ao uso da paródia de formas narrativas, da intertextualidade, da colagem de textos, da fragmentação narrativa, dentre outros processos que o autor utliliza na construção de sua literatura.

O capítulo sobre L'Angelo Nero procura mostrar o diálogo que o autor estabelece com a história recente italiana e européia, sobretudo, portuguesa. Não faltam, neste livro, exemplos de diálogos intertextuais, a começar pelo título, que é retirado de um poema de Eugenio Montale ${ }^{10}$. No que se refere às coletâneas anteriores, Tabucchi faz um avanço em direção ao real: embora ainda predomine o sonho e a imaginação como formas de "rovesciamento" - inversão - da realidade, a ótica de Tabucchi recai sobre o posicionamento crítico do escritor em relação à sociedade e à história. E é justamente esta postura do autor que torna a obra mais pessimista em comparação às anteriores: neste livro a temática da violência está presente em quase todos os contos; a presença maléfica de um "anjo negro" entrelaça as narrativas, conferindo-lhes certa organicidade.

\footnotetext{
${ }^{10}$ Montale, E. L'Angelo Nero. In: Tutte le poesie. Org. Giorgio Zampa. Milão: Arnoldo Mondadori Ed., 1990. pp. 378-379.
} 
Como dissemos, a obra de Antonio Tabucchi foi bastante traduzida no Brasil, não só os romances mais famosos, como também alguns de seus contos e novelas. Não obstante o interesse do público brasileiro pela sua literatura, no que se refere aos estudos teóricos e analíticos da obra tabucchiana, ainda se produziu pouca literatura crítica sobre o autor no país. É possível constatar, todavia, a presença de alguns artigos acadêmicos e teses sobre a sua narrativa, tematizando vários aspectos críticos, adotando, sobretudo, perspectivas comparatistas, temáticas e estruturais ${ }^{11}$. Existem vários artigos esparsos no âmbito acadêmico, publicados em revistas e periódicos, mas ainda nenhuma publicação editorial destes estudos ou teses, que possa dar maior relevância à produção crítica nacional.

Neste sentido, procuramos com este trabalho, contribuir, de alguma forma, para um aprofundamento do conhecimento crítico e teórico da obra do escritor italiano no âmbito acadêmico, assim como oferecer ao estudioso brasileiro uma breve apresentação da narrativa tabucchiana, de seus temas e procedimentos principais. Pretendemos, por fim, colaborar nas discussões já existentes sobre a obra do autor, e mais que responder a questões, procuramos colocá-las, visto que, durante todo o nosso percurso, deparamos com a perspectiva de que a literatura de Antonio Tabucchi é uma "arte da inquietação": apresenta perguntas e nunca respostas definitivas, tem como projeto o desafio das certezas, a formulação de perguntas, a revelação da criação ficcional onde antes era aceita a existência de alguma "verdade absoluta"12.

\footnotetext{
${ }^{11}$ Em especial, destaco as teses De viagens e de viajantes: a viagem imaginária e o texto literário, de Silvana Pessoa de Oliveira, defendida na UFMG, em 1995, que analisa o tema da viagem de uma perspectiva comparatista, abordando Notturno indiano; e a tese de doutorado História e Literatura na Lisboa de Salazar: O ano da morte de Ricardo Reis $e$ Sostiene Pereira, de Cátia Inês Berlini de Andrade, apresentada à UNESP, em 2001.

${ }^{12}$ Hutcheon, L. Poética do Pós-Modernismo. cit., p. 73.
} 


\section{A NARRATIVA DE ANTONIO TABUCCHI: UMA BREVE APRESENTAÇÃO}

“... la finzione dichiarata è molto più accettabile della finzione finta”.

Antonio Tabucchi.

A narrativa de Antonio Tabucchi surge no cenário cultural italiano em meados dos anos de 1970 - seu primeiro romance, Piazza d'Italia, é publicado em 1975, após as experimentações artísticas e literárias das vanguardas do período 1960-70. Sua literatura, no entanto, afirma-se na década de 1980, com a publicação de seu primeiro livro de contos, Il gioco del rovescio.

O romance de estreia, Piazza d'Italia, pode ser considerado uma metanarrativa historiográfica $^{13}$ : é uma reescrita da história, uma reflexão sobre a história italiana contada na perspectiva dos perdedores, dos anti-heróis, dos que estão à margem da história oficial. Ao narrar a história de três gerações de uma família de revolucionários, a trama percorre quase cem anos de história italiana à luz dos ideais anárquicos republicanos, inserindo-se numa tradição literária que vai de Giovanni Verga a Beppe Fenoglio.

A fábula, definição dada pelo próprio autor, "fábula popular em três tempos" favola popolare in tre tempi - começa pelo final da história, com a morte do personagem Garibaldo, morto por um ideal que não faz mais sentido. A trama é percorrida retrospectivamente, entrecortada por previsões do horóscopo e pelo tempo que, na narrativa, adquire a dimensão da coletividade, representada pelo trabalho dos lavradores nos campos, como nas obras I Malavoglia, de Verga e Fontamara, de Silone. Ao escorrer das horas de trabalho que dão ritmo à vida do pequeno povoado, um

\footnotetext{
${ }^{13}$ Uso o termo conforme a definição de Linda Hutcheon, ou seja, um tipo de narrativa híbrida, em que a relação entre literatura e história é problematizada, como naqueles "romances famosos e populares que são intensamente auto-reflexivos e, mesmo assim, de maneira paradoxal, também se apropriam de acontecimentos e personagens históricos”. In: Poética do Pós-Modernismo. cit.
} 
"borgo" toscano, próximo do mar, contrapõe-se o tempo individual de Volturno e de sua família.

Seu segundo romance, Il piccolo naviglio, publicado em 1978, assim como Piazza d'Italia, são, segundo Trentini, narrativas que servem ao escritor como exercícios de escrita e aprendizagem ${ }^{14}$ e têm como tema principal o tempo: o tempo que perturba as leis de sucessão temporal, confundindo passado e futuro. Em Piazza d'Italia, memória e previsão se misturam em antecipações e premonições que tornam impossível a decifração das mensagens. Assim, a fábula, o horóscopo e o tempo introduzem o leitor numa atmosfera mítica, em que todas as leis da realidade são relativizadas a favor de uma lógica do fantástico ${ }^{15}$.

A estrutura de representação especular destes romances, a coexistência e a sobreposição temporal - o tempo passado narrado, misturado ao tempo presente, daquele que narra, apresentando planos temporais alternados e simultâneos introduzem e preanunciam um fazer poético: estão presentes em Il gioco del rovescio, livro emblemático para a configuração da poética do escritor.

Em sua narrativa, Tabucchi frequentemente opta pela mistura de planos temporais e pela coexistência de tempos diversos em lugar de uma temporalidade cronológica, linear, definitiva. A possibilidade de retorno temporal como "correção definitiva" que é negada à vida é, para o autor, a tarefa da arte narrativa, que se de um lado pode percorrer a história, no seu revés, refazendo-a, por outro lado, tem o poder de criar mundos possíveis, alternativos, e isto não se deve apenas a uma mistura entre "l'accaduto e ciò che deve ancora avvenire; ma anche al trascorrere, con l'ausilio del sogno, di passato, presente e futuro" $"$.

Como dissemos, Tabucchi inicia sua carreira literária com a publicação de romances e devido a sua capacidade de conjugar "leggibilità, intrattenimento e influenza dei modelli classici" ${ }^{17}$, o crítico literário Stefano Tani o situa entre os escritores contemporâneos que podem ser caracterizados por um "stile misurato in cui la conoscenza e la ripresa dei classici si affianca a una fluida leggibilità e a una

\footnotetext{
${ }^{14}$ Trentini, N.Una scrittura in partita doppia. cit., pp. 40 e ss.

${ }^{15}$ Trentini, N.Una scrittura in partita doppia. cit., pp. 150-151.

${ }^{16}$ Dolfi, Anna. Tabucchi: la specularità, il rimorso. cit., p. 20: “o acontecido e aquilo que ainda virá; mas também ao transcorrer, com o auxílio do sonho, do passado, do presente e do futuro."

${ }^{17}$ Tani, S. Il romanzo di ritorno. Dal romanzo medio degli anni sessanta alla giovane narrativa degli anni ottanta. Milão: Gruppo Ugo Mursia Editore, 1990. pp. 153 e ss. "legibilidade, entretenimento e influência dos modelos clássicos".
} 
metanarrativa che conosce bene le sue strutture" ${ }^{\text {18 }}$. Ainda segundo o crítico, Tabucchi se constitui como continuador ideal do que ele chama de "romanzo medio e del suo microcosmo"19, ou seja, de um tipo de romance que nasce de uma situação de crise e está centralizado no microcosmo do personagem, e que, mesmo ambientado em um espaço restrito, propõe-se como metáfora existencial ${ }^{20}$. Tabucchi é um escritor que possui um modo de escrever

\begin{abstract}
"rigoroso, in cui il piacere della bella prosa che si coniuga a leggibilità, intrattenimento, e l'influenza di modelli classici va di pari passo con qualche concessione ad uno scrivere metanarrativamente consapevole, raffinato dalle recenti acquisizioni critiche e filosofiche, o comunque da un qualche specifico tratto di relativa originalità stilistica o tematica",21.
\end{abstract}

O início dos anos de 1980 marca uma mudança no universo narrativo do autor. Tabucchi deixa de lado a escrita da História e passa a se deter na construção de textos autorreflexivos, metanarrativos:

\begin{abstract}
"ci si allontana dalla riscrittura della Storia per avventurarsi in testi autoriflessivi nei quali il lettore viene coinvolto in giochi metanarrativi: rebus, opposti, rovesci, misteri destabilizzano ogni concezione tradizionale della narrativa",22.
\end{abstract}

\footnotetext{
${ }^{18}$ Tani, S. Il romanzo di ritorno. cit., pp. 153 e ss. "estilo comedido, no qual o conhecimento e a retomada dos clássicos se aliam a uma legibilidade fluida e a uma metanarrativa que conhece bem as suas estruturas".

${ }^{19}$ Tani, S. Il romanzo di ritorno. cit., p. 15: "romance médio e do seu microcosmo".

${ }^{20}$ Tani, S. Il romanzo di ritorno. cit., pp. 15 e ss. "Il mondo provinciale e agrario del microcosmo è proprio ora, negli anni sessanta e settanta, sottoposto all'attacco dell'industrializzazione e dei mass media (...) minacciato si ritira in se stesso, cerca la celebrazione dei propri valori. (...) la narrazione diviene subito memoria e si colora di pietas per ciò che gli è già irreparabilmente trascorso e perduto"./"O mundo provinciano e agrário do microcosmo é, justamente agora, nos anos de 1960 e 70, submetido ao ataque da industrialização e dos mass media (...) ameaçado, se fecha em si mesmo, procura a celebração dos próprios valores. (...) a narração se torna imediatamente memória e se colore de pietas por aquilo que lhe é irreparavelmente passado e perdido".
}

${ }^{21}$ Tani, S. Il romanzo di ritorno. cit., pp. 153 e ss: "rigoroso, em que o prazer da boa prosa que se conjuga a legibilidade, entretenimento, e a influência de modelos clássicos são acompanhados por algumas concessões de uma escrita metanarrativamente consciente, refinada pelas recentes aquisições críticas e filosóficas, ou até mesmo, por alguns traços específicos de relativa originalidade estilística ou temática".

${ }^{22}$ Brizio-Skov. Antonio Tabucchi: navigazioni in un arcipelago narrativo. cit., p. 21: "afasta-se da reescrita da História para se aventurar em textos autorreflexivos, nos quais o leitor é envolvido em jogos metanarrativos: rebus, opostos, reversos, mistérios, desestabilizam toda concepção tradicional da narrativa". 
Quanto à forma, a década de 1980 é um período em que Tabucchi se dedica particularmente à publicação de narrativas breves: sua primeira coletânea de contos, Il gioco del rovescio, é de 1981 (em 1988, Tabucchi lança uma segunda edição do livro, acrescida de prefácio e de outros três contos). Em 1983, publica Donna di Porto Pim, misto de diário de viagens e contos. Em 1985, publica Piccoli equivoci senza importanza; em 1987, I volatili del Beato Angelico e em 1991, publica L'Angelo Nero, todos coletâneas de contos. A forma breve é praticada com maior constância e conhecimento porque, segundo o autor, presta-se melhor à possibilidade de "scandagliare con più facilità, con più sfumature e varietà, i temi che interessano maggiormente lo scrittore" ${ }^{23}$. Tabucchi acredita que os contos são agrupados nas coletâneas por temas ou conceitos, os quais, em geral, poderiam ser apresentados na forma romanesca, e que a escolha pela forma é uma possibilidade do escritor, no entanto, nota que a forma breve intensifica o efeito de entrega imediata e precisa do texto $^{24}$.

O escritor não abandona, todavia, a forma romanesca, e em 1984, publica o romance Notturno indiano, aparente narrativa policial em que a busca do protagonista por um amigo desaparecido na Índia, revela-se, depois, como uma busca pela própria identidade. A narrativa conjuga a "saudade" do europeu em terra desconhecida com o revés irônico do final, em que o narrador propõe uma versão invertida da história lida, deixando em aberto várias soluções possíveis. Notturno indiano mistura gêneros romanescos como a narrativa policial e o romance existencial, procedimento que se repete no romance Il filo dell'orizzonte, de 1986.

Em Il filo dell'orizzonte o protagonista, que tenta descobrir a identidade de um cadáver, também é um personagem em busca de si mesmo. Trata-se de uma história que parte de um dado da realidade, ao qual o protagonista Spino tenta dar um sentido, mas quanto mais avança na investigação, mais obscura e cheia de "vazios" ela se torna.

Como em Notturno indiano, o romance termina sem solução, o leitor não consegue saber se estes protagonistas atingem ou não seus objetivos, se encontram aquilo que buscam, aliás, é chamado a construir para si um "final", outra verdade que o

\footnotetext{
${ }^{23}$ Trentini, N. Una scrittura in partita doppia. cit., p. 35: "sondar com maior facilidade, com mais nuances e variedades, os temas que mais interessam ao escritor".

${ }^{24}$ Trentini, N. Una scrittura in partita doppia. cit., p. 35.
} 
autor não soube ou não quis predeterminar ${ }^{25}$. Todavia, neste processo, o leitor percebe que, no desenrolar da narrativa, para a afirmação da identidade dos personagens, é imprescindível que estes personagens se confrontem com as imagens de si mesmo construídas pelos outros.

Nesse confronto do protagonista, o leitor é lançado em um universo impreciso, em que cada pista oferecida pelo narrador se revela falsa e índice de outro mistério que se configura. O sentido, desta forma, é sempre incerto, a experiência narrada também é falseada, plena de imaginação, fantasmagoria, lembranças confusas que desnorteiam o leitor em busca de uma "conclusão" para o mistério apresentado. Os romances deixam em aberto várias soluções possíveis, sem desapontar ou confundir o leitor, mas fazendo com que intua o "jogo" ficcional, transformando o caráter elusivo do texto em prazer de leitura. De acordo com Stefano Tani:

\begin{abstract}
"Tabucchi in Il filo dell'orizzonte traduce in tecniche gradevoli e sfumate gli aspetti più dissonanti, rispetto al romanzo tradizionale, della narrativa postmoderna: mostra la finzione del narrare ma rispetta l'integrità e la piacevolezza del racconto; delude il lettore che si aspetta una spiegazione razionale del mistero ma allo stesso tempo lo blandisce con un crepuscolarismo agrodolce e suadente, a tal punto da rendere la logica soluzione tipica del giallo atmosfericamente inappropriata rispetto alla 'dissolvenza' emotiva e metafisica che viene proposta; esibisce elementi innovativi attenuandoli però all'interno di un contesto raffinatamente tradizionale" 26 .
\end{abstract}

Já as duas coletâneas de narrativas breves Donna di Porto Pim (1983) e I volatili del Beato Angelico (1987), publicadas paralelamente aos romances, são compostas sob o signo da fragmentariedade, da inconsistência "che ha un suo riflesso nella presenza di tanti fantasmi anche all'interno di questi romanzi mancati'"27.

\footnotetext{
${ }^{25}$ Orvieto, P. “1985-1991. Gli anni del giallo e del suo 'oscuramento"”. In: I 'Notturni' di Antonio Tabucchi. Atti di seminario. Firenze, 12-13 maggio 2008. Roma: Bulzoni Editore, 2008, p. 90.

${ }^{26}$ Tani, S. Il romanzo di ritorno. cit., p. 160: "Tabucchi, em Il filo dell'orizzonte, traduz em técnicas agradáveis e matizadas os aspectos mais dissonantes, em relação ao romance tradicional, da narrativa pósmoderna: mostra a ficção do narrar, mas respeita a integridade e a sutileza da narração; desaponta o leitor que espera uma explicação racional do mistério, mas o seduz, ao mesmo tempo, com um crepuscularismo agridoce e persuasivo, a tal ponto que torna a solução lógica, típica do romance policial, inapropriada atmosfericamente, em relação à 'dissolução' emotiva e metafísica que é proposta; exibe elementos inovadores, atenuando-os, porém, dentro de um contexto refinadamente tradicional".

${ }^{27}$ Tani, S. Il romanzo di ritorno. cit., p. 159. "que também tem seu reflexo na presença de muitos fantasmas nesses romances malogrados".
} 
Donna di Porto Pim é um aparente "livro de viagens", um misto de narrativas fragmentos - que transitam entre a poesia e a crônica, partindo de histórias reais e trágicas, passando por biografias inventadas, descrições da paisagem, fragmentos de manuais de pesca, alcançando um alto grau de elaboração ficcional. Esta “obra aberta e simbólica" 28 , concentra narrativas que giram em torno de personagens típicos das Ilhas dos Açores: "as baleias que, mais do que animais, parecem metáforas" 29 . Dentre os muitos autores que o livro cita, como os poetas Antero de Quental e Carlos Drummond de Andrade, que servem de base para a construção de dois fragmentos, aparece também o romance Moby Dick, de Herman Melville, a quem é dedicada uma seção inteira do livro que conta sobre as baleias e os baleeiros.

I volatili del Beato Angelico é uma espécie de "tour guidato nel laboratorio dello scrittore, dove i protagonisti sono i romanzi e i racconti mancati che hanno natura larvale" ${ }^{, 30}$. Como define o autor na nota inicial, mais que "quasi-racconti", constituem um "rumore di fondo" 31 , transformado em escrita. Como nos romances iniciais, e à maneira das Ficções de Borges, a coletânea tematiza o tempo - o do irreversível ou o da profecia, se pensarmos, por exemplo, nos personagens de "Passato composto. Tre lettere", Dolores Ibarruri e Don Pedro, que têm seus destinos previstos por outros personagens que também existem "fuori dal libro",32.

Nesse período, o autor se dedica também à publicação de obras críticas sobre Fernando Pessoa. Em 1990, publica Un baule pieno di gente, obra crítica que explica um pouco a escolha e a presença de Pessoa como "duplo" ou "alter-ego"33 do autor, em todo caso, como fonte de inspiração para muitas de suas narrativas ficcionais. Além disso, a obra de Pessoa é a fonte da qual Tabucchi retira um conceito importante para a sua narrativa: ao analisar a figura de Bernardo Soares, personagem considerado semiheterônimo do poeta português, Tabucchi resgata a ideia de inquietude, apontando para

\footnotetext{
${ }^{28}$ Tarani, T. "L'inutile faro della notte. I raggiri del fantastico in Donna di Porto Pim”. In: I 'Notturni' di Antonio Tabucchi. cit., p. 161.

${ }^{29}$ Tabucchi, A. Donna di Porto Pim e altre storie. 12a . ed. Palermo: Sellerio Editore, 1995. Cito da edição brasileira. Mulher de Porto Pim. Trad. Rachel Gutiérrez. Rio de Janeiro: Rocco, 1999. p. 11.

${ }^{30}$ Tani, S. Il romanzo di ritorno. cit., p. 159. "tour guiado no laboratório do escritor, em que os protagonistas são os romances e os contos malogrados que têm natureza embrionária".

${ }^{31}$ Tabucchi, A. I volatili del Beato Angelico, $10^{\circ}$. ed. Palermo: Sellerio, 2005. p. 10. Ed. Bras. Os voláteis do Beato Angélico. Trad. Ana Lucia Belardinelli. Rio de Janeiro: Rocco, 2003. p. 8: "quase-contos"; "ruído de fundo".

${ }^{32}$ Turi, Nicola. "Requiem per una stagione creativa: lo spettro di Borges e l'avvento di Saramago". In: I 'Notturni' di Antonio Tabucchi. cit., p. 235: "fora do livro".

${ }^{33}$ Jansen, Monica. "Tabucchi: molteplicità e rovescio". In: Piccole finzioni con importanza. Valori della narrativa italiana contemporanea. Org. Nathalie Roelens e Inge Lanslots. Ravenna: Longo Editore, 1991. pp. 137-146.
} 
o "desassossego" de Soares, seu tédio, sua incapacidade de vivenciar o cotidiano, sua "incompetência em relação à vida":

\begin{abstract}
"Bernado Soares vive e non vive: il suo esistere si pone fra la vita e la coscienza di essa, fra l'essere e l'idea di essere, fra se stesso e l'idea di se stesso, fra il reale che egli guarda e il reale che egli riproduce nella sua descrizione letteraria”, ${ }^{34}$.
\end{abstract}

Este desassossego, segundo Tabucchi, é a manifestação do "Mal de Viver", a perda ou privação da tranquilidade que caracteriza não só o heterônimo pessoano como também o sujeito moderno. Partindo da leitura do Livro do desassossego de PessoaSoares, Tabucchi isola a ideia de "desassossego", tomando-a como um conceito fundador da representação literária do século XX. Observa, deste modo, que a literatura do século XX funciona como uma espécie de "sismógrafo", capaz de registrar até "as mais mínimas vibrações" do desassossego. Para Tabucchi, o desassossego pessoano é caracterizado por

\footnotetext{
"um desalento de viver, uma incompetência diante da vida e acima de tudo, uma sensação de estranhamento em relação a ela (...) e esta incompetência diante da vida é como uma doença, uma incompetência que se modifica e se transforma em estranhamento com a realidade circundante" ${ }^{\circledR 3}$.
}

Tabucchi usa o conceito do desassossego para analisar a literatura do século XX, em particular a literatura de Carlo Emilio Gadda, considerando-a "expressão trágica da Itália" no século XX. Nesta perspectiva, a inquietude pode ser considerada também um símbolo da literatura tabucchiana, preanunciando um "descompasso com a realidade circundante que faz com que o sujeito se sinta estrangeiro em relação a si mesmo"36. Descompasso este que desemboca constantemente no desconsolo, no tédio, na

\footnotetext{
${ }^{34}$ Tabucchi, A. "Bernado Soares: uomo inquieto e insonne". In: Un baule pieno di gente. Milão: Feltrinelli, 1990, p. 71. "Bernado Soares vive e não vive: o seu existir se coloca entre a vida e a consciência da vida; entre o ser e a ideia de ser; entre o si mesmo e a ideia de si mesmo; entre o real que ele olha e o real que ele reproduz na sua descrição literária".

${ }^{35}$ Tabucchi, A. "O fio do desassossego". Trad. Sergio Molina. In: Caderno Mais! Folha de São Paulo, 9/9/2001.

${ }^{36}$ Tabucchi, A. "O fio do desassossego". cit.
} 
melancolia, no estranhamento, na sensação de exílio em qualquer parte, na constatação de que o mundo não oferece resguardo ${ }^{37}$. Nesta literatura da inquietude, escrita por "escritores inquietos", como o próprio Tabucchi, encontramos personagens que vivem à deriva, entre o presente e o passado, entre a memória e a história. Os pontos de vista dos personagens assim como os narradores, são plurais; nada se fixa, a dúvida e a incerteza são a matéria prima desta escrita.

Assim, o "desassossego" está presente em sua obra, seja como concepção intrínseca de seu trabalho literário, seja como perspectiva de leitura que o autor, metaliterariamente, discute em seus textos. Como concepção literária, o "desassossego" insere a obra de Tabucchi em um contexto literário mais amplo e universal, ao mesmo tempo em que a particulariza no que se refere às escolhas temáticas e formais.

Sobre a presença de Fernando Pessoa na narrativa tabucchiana, Monica Jansen considera que Tabucchi, ao resgatar o poeta em sua obra, o faz para inseri-lo numa arte da "contaminação", na qual coexistem a aceitação da "herança" modernista e o distanciamento desta herança através da ironia e da distorção, características da literatura contemporânea e mais especificamente, da literatura pós-moderna ${ }^{38}$.

Fernando Pessoa é tema de sua obra crítica e também "personagem" de algumas de suas narrativas, sendo que em pelo menos dois romances e uma peça teatral ocupa papel importante: Requiem (1992), Gli ultimi tre giorni di Fernando Pessoa (1994) e I dialoghi mancati (1988).

Em Gli ultimi tre giorni di Fernando Pessoa, Tabucchi narra, de maneira ficcional, os dias finais do poeta em um hospital em Lisboa. Neste hospital, Pessoa, entre sonho e delírio, recebe a visita de seus heterônimos Alberto Caeiro, Ricardo Reis, Álvaro de Campos, Bernardo Soares e Antônio Mora, que vêm se despedir do poeta.

Requiem, por sua vez, é uma narrativa fantástica em que mortos e vivos se encontram no plano da "alucinação" do protagonista que é narrador e sonhador ao mesmo tempo. No plano dessa alucinação, mistura de fantasia e recordações, o protagonista reencontra seus mortos, seu pai ainda jovem, amigos queridos já falecidos, como Tadeus e Isabel, e também o poeta "Convidado", numa clara alusão a Fernando Pessoa. A narrativa se passa em um intervalo de doze horas, numa tarde ensolarada em

\footnotetext{
${ }^{37}$ Julio Pimentel Pinto. "A literatura do desassossego". In: EntreLivros, julho de 2006. Ano 2, no.15. São Paulo: Ediouro. p. 62.

${ }^{38}$ Jansen, M. Il dibattito sul postmoderno in Italia. cit., pp. 297 e ss.
} 
Lisboa. O tempo narrativo se comprime e se dilata, passado e presente se confundem e se invocam, e o protagonista, suspenso entre consciência e inconsciência, pode encontrar seus fantasmas no mesmo plano espaciotemporal.

Com Requiem Tabucchi não só resgata temáticas importantes como "l'ambiguità onirica, l'incomprensione del passato, l'incertezza identitaria"39, como também presta uma homenagem ao poeta português, homenagem que se realiza já na escolha do uso da língua portuguesa para a escrita do romance, língua que Tabucchi conhece bem, e que considera "um lugar de afeto e de reflexão" 40 .

Alguns críticos da obra de Tabucchi consideram Requiem um divisor de águas em sua carreira literária, pois é um texto " $d i$ confine oltre che sul confine, quello assai incerto che separa sogno (o incubo) e veglia" ${ }^{41}$. A fase inicial seria marcada por uma "presença obsessiva do sonho": Nives Trentini, como dito anteriormente, acredita que a primeira fase se inicia em 1981, com a publicação de Il gioco del rovescio, e segue até 1992, com a publicação de Requiem. Nessa fase, a estudiosa destaca a presença obsessiva do sonho, considerando que toda a obra narrativa desse período caminha em direção a uma espécie de "centro onírico", alcançado justamente com a publicação de Requiem. Já a outra fase se inicia com a publicação de Sostiene Pereira, e estaria centrada na busca em direção ao real, em que Tabucchi se debruça sobre o desafio de lidar com a realidade política e social.

A obra crítica de Trentini, Una scrittura in partita doppia, data, entretanto, de 2003. Com as publicações posteriores do autor, podemos perceber, todavia, que a vertente onírica nunca é totalmente abandonada, tendo sido colocada um pouco à parte em obras como Sostiene Pereira ou La testa perduta di Damasceno Monteiro, de 1997 - romances centralizados na dimensão política e em acontecimentos coletivos que influenciam a vida dos indivíduos e a sua liberdade - mas retorna com força em obras como Tristano muore, romance publicado em 2004.

A partir de 1994, temos, então, uma fase considerada mais "realista" da obra tabucchiana, com a publicação dos dois romances mais importantes para a sua carreira, que tornaram o escritor famoso no mundo todo: Sostiene Pereira e La testa perduta di

\footnotetext{
${ }^{39}$ Turi, Nicola. "Requiem per una stagione creativa: lo spettro di Borges e l'avvento di Saramago". In: $I$ 'Notturni' di Antonio Tabucchi. cit., p. 231: "a ambiguidade onírica, a incompreensão do passado, a incerteza da identidade".

${ }^{40}$ Tabucchi, A. Nota a Requiem. Cito da ed. bras., Rocco, 2001. p. 4.

${ }^{41}$ Turi, N. "Requiem per una stagione creativa...". cit., p. 229: "de fronteira, mais que $n a$ fronteira, aquele muito incerto, que separa o sonho (ou o pesadelo) da vigília".
} 
Damasceno Monteiro. Estes romances, traduzidos em vários países, inclusive no Brasil, consagraram o escritor italiano. Sostiene Pereira é ambientado em Lisboa, no verão do ano de 1938, pouco antes da invasão da Polônia por Hitler. Pereira é um homem que não vive a história como protagonista, é um jornalista que durante o regime salazarista, escreve obituários em um jornal português. À diferença de outros romances que tratam do salazarismo português, o personagem de Pereira é um homem atormentado, indeciso, uma espécie de anti-herói, de figura menor, que se auto-exclui da história, e que, no final da narrativa, adquire consciência e cumpre seu gesto de resgate, ao participar ativamente do curso dos acontecimentos. O romance é considerado pelo autor um romance existencialista ${ }^{42}$, porque existe ali uma crise de consciência. A história oficial é uma espécie de pano de fundo ou de cenário para a ação.

Sostiene Pereira foi concebido como testemunho de um empenho civil que, tendo amadurecido na consciência do escritor em contato com uma realidade que ele viveu em Portugal nos anos de 1960, encontra expressão literária em um romance que transcende os limites históricos e geográficos. O empenho político e civil de Tabucchi é transmitido ao seu personagem, que no momento de sua tomada de consciência, dá-se conta de qual deveria ser o papel do intelectual na sociedade ${ }^{43}$.

La testa perduta di Damasceno Monteiro também se aproxima desta linha, embora neste romance predomine o componente policial. O jornalista Firmino investiga, com o apoio do advogado Lóton, um crime hediondo ocorrido na cidade do Porto. O romance aborda os problemas do abuso policial, da tortura e da marginalização das minorias éticas. A questão jornalística, com sua necessidade constante de "furos" de reportagem e a falta de étnica por parte de alguns jornais também é um dos focos do romance.

Sostiene Pereira e La testa perduta di Damasceno Monteiro são obras “abertas" e “especulares", que tendem à fragmentariedade. Existe uma continuidade visível entre os dois romances, pois Sostiene Pereira termina com o protagonista lançando um último olhar ao lençol que cobre o corpo do jovem Monteiro Rossi, assassinado pela polícia política salazarista, enquanto se apressa para sair de cena, sem conhecer seu destino, deixando ao leitor uma série de perguntas em aberto. Já La testa perduta di Damasceno

\footnotetext{
${ }^{42}$ Ferraro, B. "Introduzione a Sostiene Pereira". In: Tabucchi, A. Sostiene Pereira.Turim: Loescher Editore, 1995.

${ }^{43}$ Ferraro, B. "Introduzione a Sostiene Pereira”. cit.
} 
Monteiro começa com o olhar do cigano Manolo que encontra o cadáver sem cabeça de outro "Monteiro". Dois jovens assassinados de maneira cruel e dois jornalistas que tentam, através de seu trabalho, revelar os bastidores "políticos" dos dois crimes. Podese dizer que os dois são romances de "formação", conforme a definição do próprio Tabucchi para Pereira, mas enquanto no primeiro temos um "velho" que faz emergir o seu "eu hegemônico", no segundo temos o jovem Firmino, que deve se formar como profissional $^{44}$.

Já em Tristano muore, temos o retorno da presença do sonho como temática. Nesse romance, um ex-combatente de guerra, doente, na sua agonia de morte, resolve contar sua vida a um escritor, ou melhor: dar seu testemunho de vida, de uma vida vivida num século de catástrofes a um escritor que ouve a narrativa e a transforma em escritura. Entre sonhos e alucinações provocadas pela febre e pela morfina, Tristano narra sua vida, seus amores, o combate na guerra, enquanto reflete sobre o século que está sendo deixado para trás. O escritor, que recolhe este testemunho oral para depois narrá-lo por meio da escrita, retoma um procedimento comum à literatura de Tabucchi que frequentemente nos dá referências da origem de seus contos, fazendo notar que algumas de suas narrativas foram construídas a partir de histórias transmitidas oralmente. Tristano não conta apenas histórias reais, mas também os sonhos, que considera o "princípio da literatura":

“... i sogni non si registrano, si devono ascoltare e poi riscrivere, tu stai solo a sentire, apri bene le orecchie e poi riscrivilo, è il principio della letteratura, raccontare il sogno di un altro" 45 .

E de fato, esse princípio rege uma coletânea de 1992, Sogni di sogni, em que o autor narra sonhos de "outros" sonhadores, desde Dédalus até Freud, passando por Leopardi, Caravaggio, Debussy, Garcia Lorca. Escrever os sonhos dos outros constitui uma metáfora da experiência literária, e com esta metáfora Tabucchi parece querer dizer que a tradição literária se desenha como um sonho, em que a recordação dos escritores do passado retorna na escrita fugaz do presente, para ser lida e perpetuada num futuro

\footnotetext{
${ }^{44}$ Trentini, N. Una scrittura in partita doppia. cit., pp. 239-240.

${ }^{45}$ Tabucchi, A. Tristano muore. Una vita. Milão: Feltrinelli Editore, 2004. p.122: “...os sonhos não se registram, devem ser ouvidos e depois escritos, você apenas ouça, abra bem os ouvidos e depois escrevao, o princípio da literatura é contar o sonho de outro".
} 
vindouro. São narrativas breves que concentram a densidade do imaginário poético do sonho ${ }^{46}$.

Em um de seus escritos ensaístico, publicado em Autobiografia altrui (2003), Tabucchi dá notícias da presença do sonho no romance Requiem, dizendo que:

\footnotetext{
"La storia dei sogni accompagna la storia degli uomini. Da quando ha imparato a raccontarsi, l'uomo racconta i suoi sogni, attribuendo al fatto di sognare motivazioni diverse" ${ }^{, 47}$.
}

Essa presença constante do sonho, mais que uma temática, pode ser particularmente interessante na investigação de uma poética tabucchiana, se consideramos que o lado onírico é aquele mais propenso a subverter a ordem das coisas, a instaurar o avesso e o equívoco, a exaltar a esfera da multiplicidade e fazer com que as fronteiras entre real e irreal se confundam ou se anulem ${ }^{48}$, temas fundamentais presentes nas coletâneas de contos Il gioco del rovescio, Piccoli equivoci senza importanza e L'Angelo Nero, todas escritas e/ou publicadas nos anos de 1980.

Il gioco del rovescio apresenta temas, procedimentos e expedientes literários que serão recorrentes nas narrativas posteriores de Tabucchi. Nesse sentido, pode ser visto como notas iniciais de uma poética. Il gioco del rovescio possui como natureza embrionária uma "intenção interrogativa", que será retomada e ampliada em Piccoli equivoci senza importanza e em L'Angelo Nero criando um efeito de pluralização e complicação da experiência vivida pelos personagens.

Em termos de poética, as três coletâneas são constituídas a partir da presença marcante do "onirismo metaliterário" 49 , que alarga as fronteiras entre a ficção e o real, questiona as bases da noção de realidade, problematiza o modelo da visão realista da representação - ao mesmo tempo em que se utiliza critica e parodicamente dessa tradição realista, já que Tabucchi é um escritor que herda uma tradição italiana de "realismos".

\footnotetext{
${ }^{46}$ Ferro, Roberto. In: http://www.um.es/tonosdigital/znum3/perfiles/EntornoTabucchi.htm. Acesso em 20 de março de 2013.

${ }^{47}$ Tabucchi, A. Autobiografia altrui. Poetiche a posteriori. Milão: Feltrinelli, 2003. p. 25: "A história dos sonhos acompanha a história dos homens. Desde que o homem aprendeu a narrar, o homem conta os seus sonhos, atribuindo ao fato de sonhar motivos diversos".

${ }^{48}$ Trentini, N. Una scrittura in partita doppia. cit., pp. 40 e ss.

${ }^{49}$ Trentini, N. Una scrittura in partita doppia. cit., pp. 40 e ss.
} 
Em 2009, após quase dezoito anos da publicação de L’Angelo Nero, Tabucchi volta a publicar uma coletânea de contos: Il tempo invecchia in fretta. Nove storie. Os contos ali reunidos tratam da passagem do tempo, relacionando memória, sonho e melancolia, enquanto apresenta personagens que tentam reelaborar acontecimentos do passado. Para o autor, vivemos em um tempo de complicação:

\footnotetext{
"Siamo in un'epoca di complicazione del tempo, il tempo è una dimensione inafferrabile, oggi triplicata. Einstein dice de sapere cos'è il tempo. Bergson parla del tempo della coscienza, ma poi arriva la modernità, la postmodernità e il tempo reale grazie alla tecnologia. E il tempo reale porta con sé un turbamento" $" 50$.
}

Esta temática se dá por meio da narrativa de histórias reais, ambientadas em alguns países do Leste Europeu, como o singelo conto "Nuvole", que narra sobre um oficial italiano que sofreu radiações de urânio durante o período que serviu em Kossovo. Em um balneário turístico, durante as férias, o oficial ensina a uma menina a arte de ler o futuro nas nuvens.

Em 2011, o autor lança o que seria seu último livro de contos, dada sua morte em 2012: Racconti con figure é um mosaico de histórias atreladas a figuras e imagens, sobretudo pinturas, que servem como sugestão para as narrativas. Organizada como uma partitura musical, a obra se divide em três momentos ou "movimentos": "Adagi", “Andanti con brio" e "Ariette". Tabucchi se vale, nesta coletânea, do processo de colagem de trechos de obras literárias, em particular poemas, além das imagens que se combinam a narrativas fragmentadas, em que a instabilidade da linguagem e do discurso é predominante. Na composição desse mosaico, vários poemas de poetas diversos como Eugenio Montale, Mário de Sá-Carneiro, Jorge Luís Borges, Wislawa Szymborska, Fernando Pessoa, dialogam entre si, em um processo fecundo de intertextualidade, característico da obra tabucchiana. As figuras, pinturas e fotografias ditam percursos de leitura que podem ser combinadas e recombinadas ao gosto do leitor. Mais que contos, essa coletânea apresenta recortes narrativos, fragmentos compostos, mistura entre

\footnotetext{
${ }^{50}$ Entrevista a Antonio Tabucchi, org. Elena Torre. In: http://www.mangialibri.com/node/5454. Acesso em 02/06/2014. "Estamos em uma época de complicação do tempo, o tempo é uma dimensão inapreensível, hoje triplicada. Einstein diz saber o que é o tempo. Bergson fala de tempo da consciência, mas depois chega a modernidade, a pós-modernidade e o tempo real graças à tecnologia. E o tempo real traz consigo uma perturbação".
} 
escrita, som e imagem, em um experimento formal que se mostra bastante novo em relação ao conjunto da obra tabucchiana.

O último romance, Per Isabel, publicado postumamente em 2013, foi escrito, entretanto, em diversos anos, sendo efetivamente concluído em 1996. Uma narrativa em que ecoa o Notturno indiano e sua busca por um personagem misteriosamente desaparecido. Desta vez, a personagem de Isabel, presente em vários contos de Tabucchi, é procurada por Waclaw/Tadeus, que percorre Portugal e algumas de suas colônias, chegando até Macau, buscando indícios e pistas do paradeiro da mulher de quem havia se separado anos atrás e da qual não tinha notícias. Em sua busca, o protagonista se depara com a possibilidade da morte de Isabel que, aos poucos, descobre ser apenas um instrumento para seu ingresso na clandestinidade, visto que ela era militante do partido comunista, no período salazarista. $\mathrm{O}$ romance, apresentado como se fosse uma investigação policial, revela-se, capítulo após capítulo, uma narrativa fantástica e existencial. O próprio protagonista o define como a construção de uma "mandala", um desenho feito a partir de círculos e outras figuras geométricas que, para os budistas, significa o processo pelo qual se constrói o cosmo, o universo, de dentro para fora, simbolizando o crescimento interior, uma tentativa de conhecimento de si mesmo.

Nesses três últimos livros, apesar das diferenças formais que apresentam, a temática recorrente é a da passagem do tempo e a consciência de sua irreversibilidade, tema que perpassa toda a obra do escritor italiano, fazendo com que sua literatura frequente o lugar simbólico do irreversível, da saudade, daquilo que foi condenado a não retornar e a não existir mais ${ }^{51}$.

Além disso, Tabucchi é um autor que dialoga com a contemporaneidade, por meio de sua forma narrativa e de suas questões temáticas, procurando representar esse diálogo mediante uma concepção peculiar de literatura e modo de fazer poético, o que torna sua obra particular no âmbito da literatura italiana contemporânea.

\footnotetext{
${ }^{51}$ Dolfi, Anna. Gli oggetti e il tempo della saudade. Le storie inafferrabili di Antonio Tabucchi. Florença: Le Lettere, 2010. p. 24.
} 


\title{
2. IL GIOCO DEL ROVESCIO: NOTAS PARA UMA POÉTICA
}

\subsection{A POÉTICA “DEI BUCHI” E A CONSTRUÇÃO DO PERSONAGEM TABUCCHIANO}

\begin{abstract}
"Il rovescio o l'equivoco possono essere dei modi di leggere la realtà che ci circonda, di guardare l'altra faccia della medaglia".
\end{abstract}

Antonio Tabucchi.

Como vimos, com a publicação de Il gioco del rovescio, Tabucchi dá início a uma poética do fragmento, ou poética “dei buchi”, conforme o autor a chama em um artigo publicado na revista italiana Alfabeta:

"Le mie storie, purtroppo, sono piene di buchi. Vi si aggirano presenze sfuggenti, personaggi che non riescono ad essere veri personaggi ma solo immagini sbiadite, fisionomie umbratili, parvenze. Eppure, come li ho inseguiti i miei personaggi! Li ho generosamente ricevuti dentro di me, li ho trattati come ospiti d'onore, e loro si sono sempre rifiutati di mostrarsi a tutto tondo, di saturare il mio Io con una presenza massiccia e imprescindibile, lasciando ampie camere d'aria, zone di vuoto nelle quali i pistoni della coscienza non pompano con un alito pieno e consapevole, ma avanzano sballando, tentennando, battendo in testa. Forse questi personaggi si sono adombrati per l'angusto spazio che ho loro offerto. Volevano la villa sontuosa e agiata del romanzo, e io ho offerto loro un modesto condominio: il monolocale del racconto. Potrei giustificarmi che oggi non è più il tempo di ville spaziose, ma sarebbe un'imperdonabile viltà. È la mia divisione dello spazio che non prevede ampi locali e lunghi corridoi: in essa si affastellano oggetti e persone, in una convivenza ibrida e senza stile. Se un giorno riuscissi a costruirmi una magione di campagna essa sarebbe senz'altro fatta di materiali eterogenei, un collage di molte forme: sarebbe un romanzo 
composto anche di teatro e di racconti e di dialoghi e di prose varie. Insomma, un contenitore poco elegante e molto confuso, come mi sembra essere il mondo in cui vivo" ${ }^{, 52}$.

Neste trecho, observa-se não só a predileção do autor pelos vazios, pela construção narrativa a partir destes "buracos" e fissuras, mas também por histórias incompletas de personagens desbotados, que não são mais que sombras e aparições que se impõem à imaginação, retomando a relação pirandelliana entre autor e personagens:

"I buchi, le lacerazioni, le fessure, la sospensione finale, la stessa incertezza dell'epilogo sono ricorrenti nella sua scrittura. Ogni storia resta aperta, completabile almeno parzialmente a posteriori dal lettore con l'ausilio delle altre opere e con la conoscenza delle fonti, la decriptazione dei segnali",53.

A partir deste livro, configura-se uma literatura que nasce de um "estranhamento" em relação ao real: Tabucchi se afirma como um escritor do relativo, da impossibilidade de apreender o real, da falta de certezas, da desagregação do eu, do verdadeiro que pode também ser falso, expressando uma realidade que é "così ma anche in un altro modo ${ }^{, 54}$.

\footnotetext{
${ }^{52}$ Tabucchi, A. "Il monolocale del racconto". In: Supplemento Alfabeta, no. 84. Maio de 1986. p. XII: "As minhas histórias, infelizmente, são cheias de buracos. Nelas, vagueiam presenças fugidias, personagens que não conseguem ser verdadeiros personagens, mas apenas imagens desbotadas, fisionomias sombrias, aparições. E não obstante, como eu persegui os meus personagens! Recebi-os generosamente dentro de mim, tratei-os como hóspedes honrados, e eles sempre se negaram a se mostrar integralmente, a saturar o meu Eu com uma presença maciça e imprescindível, deixando amplas câmeras de ar, zonas de vazio nas quais os pistões da consciência não bombeiam com um hálito cheio e consciente, mas avançam desembestados, vacilando, batendo a cabeça. Talvez estes personagens se ressentiram pelo estreito espaço que lhes ofereci. Queriam a mansão suntuosa e abastada do romance, e eu lhes ofereci um modesto condomínio: a quitinete do conto. Poderia me justificar dizendo que hoje não é mais tempo de mansões espaçosas, mas seria uma imperdoável covardia. É a minha divisão do espaço que não prevê amplos locais e longos corredores: nesta se agrupam objetos e pessoas, numa convivência híbrida e sem estilo. Se um dia conseguisse construir para mim um casarão no campo, esta seria, sem dúvida, feita de matérias heterogêneos, uma colagem de muitas formas: seria um romance composto também de teatro, de contos, de diálogos e de várias prosas. Em suma, um recipiente pouco elegante e muito confuso, como me parece ser o mundo em que vivo".

${ }^{53}$ Dolfi, Anna. Tabucchi: la specularità, il rimorso. cit., p. 27: “Os buracos, as dilacerações, as fissuras, a suspensão final, a mesma incerteza do epílogo, são recorrentes na sua escrita. Cada história permanece aberta, podendo ser completada, ao menos parcialmente, a posteriori, pelo leitor, com o auxílio de outras obras e com o conhecimento das fontes, a decodificação dos sinais".

${ }^{54}$ Tabucchi, A. Il gioco del rovescio. Prefácio à segunda edição. In: Racconti. $2^{\circ}$. ed. Milão: Feltrinelli, 2006. p. 9. A segunda edição de Il gioco del rovescio, publicada em 1988, foi incluída na coletânea Racconti, que agrupa também os contos de Piccoli equivoci senza importanza e L'Angelo Nero, além de dois outros contos que foram incluídos mais tarde no livro Il tempo invecchia in fretta, de 2009. Nesse trabalho, utilizamos a coletânea Racconti.
} 
Il gioco del rovescio, segundo o próprio Tabucchi, é um livro que nasce de uma descoberta: "l'essermi accorto un giorno, per le imprevedibili circostanze della vita, che una certa cosa che era 'così', era invece anche in un altro modo" 55 . De fato, os personagens de todos os contos deste livro se encontram imersos em realidades diferentes daquela imaginada, e os motivos e as causas são desconhecidos ou inacessíveis ${ }^{56}$.

A ideia de que uma coisa apresentada de um certo modo, vivida de certa maneira, pode também assumir outras perspectivas e se revelar diversa daquela forma anteriormente adotada é a essência do "jogo do revés" que, como metáfora de múltiplas soluções possíveis, modela e engendra não só o conto homônimo, mas também os outros contos do livro. Tabucchi se afirma, assim, como um escritor que observa com maravilha e também com surpresa o revés das coisas, mostrando-nos fragmentos de uma realidade reduzida a uma charada, um rebus, sem solução.

De acordo com Brizio-Skov, a obra narrativa de Tabucchi está centrada em duas constantes fundamentais: a História e a Literatura, ou no modo como este binômio se conjuga na sua literatura. Pode-se dizer que Tabucchi é um autor que volta sua atenção à realidade histórica, frequentemente situa seus personagens em um momento histórico preciso, determinado, conferindo-lhes certa fisionomia histórica, como o personagem de Pereira, por exemplo. É um escritor atento aos detalhes, com uma tendência a apreender certo olhar crítico sobre as coisas. Existe, todavia, uma problematização do conceito de real - a realidade aparece representada em sua narrativa de maneira fluida, permeada muitas vezes pelo sonho, pela memória, pelas fantasmagorias, pela invenção, distanciando-se, desta forma, de uma representação objetiva do real:

"La vicenda narrata diventa un pretesto per intaccare la nozione di realtà monolitica, per fare sì che i personaggi si confrontino con le proprie ossessioni, i propri fallimenti e i propri sogni infranti" ${ }^{, 57}$.

\footnotetext{
${ }^{55}$ Tabucchi, A. Prefazione alla seconda edizione de Il gioco del rovescio. In: Racconti. cit, p. 9. "ter percebido, um dia, pelas imprevisíveis circunstâncias da vida, que uma certa coisa que era assim, era também de um outro modo".

${ }^{56}$ Brizio-Skov. Antonio Tabucchi: navigazioni in un arcipelago narrativo. cit., p. 86.

${ }^{57}$ Brizio-Skov. Antonio Tabucchi: navigazioni in un arcipelago narrativo. cit., pp. 17-18: “Os eventos narrados se tornam um pretexto para comprometer a noção de realidade monolítica, para fazer com que os personagens se confrontem com as próprias obsessões, os próprios malogros e os próprios sonhos despedaçados".
} 
Este aparente distanciamento da história pode ser considerado uma espécie de pausa interrogativa e problemática, um momento de redefinição do próprio papel de escritor diante da história. Assim, tudo o que circunda o escritor, a sua vivência, o seu olhar sobre as coisas, o seu percurso pela cidade, o "lado de fora", tudo se torna motivo para a reflexão literária, mostrando sua consciência em relação à complexidade dos fatos e da própria narrativa. O que se sobressai, a partir desta operação, é o momento da própria criação literária:

\begin{abstract}
“(...) il momento in cui lo scrittore con tanta consapevolezza, guarda alla realtà per trasformarla o trasfigurarla, creando da un fatto esterno dei nuovi organismi viventi in un'altra dimensione, che è quella del sogno, della fantasia, del quadro iper-reale ${ }^{, 58}$.
\end{abstract}

A relação que Tabucchi estabelece com a noção de realidade, ou a frágil distinção que o autor estabelece entre realidade e ficção é outra questão temática importante na configuração de sua poética. Na literatura de Tabucchi, abundam personagens em dissonância, em desacordo com uma realidade que é sentida como caótica, contraditória, enigmática e difícil de decifrar. Em muitos de seus contos, a experiência narrada é aquela da vida urbana, com suas cidades degradadas, desordenadas, que impossibilitam o estabelecimento de relações sociais sólidas e verdadeiras, já que o próprio espaço faz com que as relações sejam despersonalizadas e descontínuas.

O espaço urbano é frequentemente visto como espaço da degradação física e social, e aparece refletido nas relações sociais, mas não de modo realístico: o espaço, aqui, não auxilia, como nos romances naturalistas, na construção da realidade externa, não serve a uma explicação da angústia humana, não é uma moldura histórico-social determinada $^{59}$. Diferente disto, o espaço é uma impressão subjetiva, índice da fragmentação do real, da inconsistência da condição do homem contemporâneo, é o

\footnotetext{
${ }^{58}$ Ammiratti, M. P., Il vizio di scrivere. Letture su Busi, De Carlo, Del Giudice, Pazzi, Tabucchi e Tondelli. Soveria Mannelli: Rubbettino Editore, 1991. p. 19: “(...) o momento em que o escritor, com muita consciência, olha a realidade para transformá-la ou transfigurá-la, criando a partir de um fato externo novos organismos que vivem em uma outra dimensão, que é aquela do sonho, da fantasia, do quadro hiper-real".

${ }^{59}$ Auerbach, Erich. Mimesis. A representação da realidade na literatura ocidental. 5a. ed. São Paulo, Perspectiva, 2004. p. 423: "Todo o espaço vital torna-se [no realismo moderno] uma atmosfera moral e física, cuja paisagem, habitação, móveis, acessórios, vestuário, corpo, caráter, trato, ideologia, atividade e destino permeiam o ser humano, ao mesmo tempo em que a situação histórica geral aparece, novamente, como atmosfera que abrange todos os espaços vitais individuais".
} 
espaço de evocação do inconsciente, é um recorte, uma colagem, um cenário transfigurado pela memória, pelo sonho, pela fantasia.

É o que acontece, por exemplo, no conto "Voci", em que uma mulher solitária atende a telefonemas de desconhecidos, desesperados, suicidas em potencial, e tenta ajudá-los a dar sentido à própria existência. Por meio da teoria da "microperspectiva", a narradora aconselha às vozes do outro lado da linha, a concentrarem a atenção sobre um detalhe da vida, a procurarem, no quotidiano, um pequeno ponto de apoio, um motivo mínimo, algo simples para se apegar e seguir vivendo. A ironia reside no fato de que ela também é um ser em desequilíbrio com o mundo, perdida na desmedida de uma cidade de anônimos, sem vínculos possíveis, agarrada à ilusão de que o companheiro, há muito tempo ausente, pode retornar a qualquer momento e preencher o vazio de seu apartamento e de sua vida.

Podemos notar esta problemática da relação do eu com o espaço não só neste conto de Il gioco del rovescio como também em romances como Sostiene Pereira e Il filo dell'orizzonte, em que os protagonistas passeiam por cidades antigas que convivem com a chegada do novo: a Lisboa de Pereira e a anônima cidade em que vive Spino, aparentemente Gênova, assolada, vazia e decrépita, cidades que desagregam, desorientam, inquietam os protagonistas, fazendo com que eles não consigam se organizar e estabelecer vínculos com o espaço e o mundo circundantes.

As cidades de Lisboa, Paris, Madrid, Gênova, Florença, dentre tantas outras, aparecem na narrativa em sua modernidade desordenada, caótica, labiríntica, desagregadora. Não só as cidades, como todos os locais em geral, as ilhas, as montanhas, as províncias e os campos italianos, aparecem como lugares fantasmáticos, evocações, lugares inacessíveis da memória e do sonho, cenários fantásticos e misteriosos, espaços do desalento e da "saudade" dos protagonistas "spaesati", como Pereira e Spino, ensimesmados e inquietos, solitários, personagens em busca de si mesmos.

Nos contos, o leitor sente falta, muitas vezes, da descrição dos personagens, enquanto vê abundar uma descrição minuciosa dos lugares, do espaço físico, da "cidade corpórea" que acompanha os percursos destes personagens. Assim, a relação com a realidade passa, necessariamente, pelo olhar de um "eu" subjetivo, muitas vezes desvencilhado do mundo, e a narrativa, constantemente, precisa lidar com um progressivo esvaziamento da subjetividade. Os personagens são sentidos como pouco 
romanescos, "quotidiani e dimessi che si defilano dalle pagine quasi come un'ombra"; são personagens que "non vengono descritti in maniera realistica, i loro tratti físici vengono assorbiti dalla loro voce" $"$.

Em Piccoli equivoci senza importanza, por exemplo, temos alguns personagens que se percebem incapazes de organizar o mundo à sua volta e de se organizar no mundo, não estabelecendo vínculos com a cidade e/ou o espaço que os cerca. Talvez porque nos espaços urbanos, a vida apareça desarticulada e degradada, as relações sociais se tornem fluidas e os laços humanos mais frágeis. Talvez porque a cidade se mostre refratária e impermeável, e o personagem não a vivencie como espaço do encontro, da interação. Neste confronto com a cidade, a personalidade se fragiliza, e por isso, não se expande para o âmbito da individualidade. É o caso do protagonista do conto "Any where out of the world", que se perde na tentativa de desvendar uma mensagem lida no jornal, que poderia estar ligada a uma aventura amorosa do passado, em um país estrangeiro. Nesta tentativa de resolver uma história de amor inconclusa, o narrador tem que lidar com suas culpas e remorsos, com os fantasmas de um tempo passado, que continuam a agir no presente. Os lugares recônditos e inacessíveis da memória - e do sonho, por sua vez, expressam o desejo dos personagens tabucchianos de estarem sempre em outro lugar, "em qualquer lugar, desde que seja fora do mundo", como assinala o personagem "baudelaireano" do conto citado, para não ter que desempenhar o papel a ele atribuído pela vida e pelo acaso ${ }^{61}$.

Nesta perspectiva do desvencilhar-se, da fuga de si mesmo, da desorientação ou do "spaesamento", na expressão italiana, a experiência se transforma em algo sem progresso, não possui caráter de formação, o herói não se constitui positivamente, aliás não se constitui, torna-se personagem "despersonalizado", condição de muitos personagens dos contos de Tabucchi, que se mostram sem nenhuma característica que os individualize; personagens que percorrem a desmedida do espaço, vagam inconsistente e insistentemente pelo tempo - presente ou passado.

\footnotetext{
${ }^{60}$ Ammirati, M. P. Il vizio di scrivere. cit., p. 114: "quotidianos e resignados, que se distanciam das páginas quase como uma sombra"; "que não são descritos de modo realístico, os seus traços físicos são absorvidos pelas suas vozes".

${ }^{61}$ Dolfi, Anna. Tabucchi: la specularità, il rimorso. cit., p. 36.
} 


\subsection{O REVÉS E O SONHO}

"A arte é uma entre as muitas realidades alternativas".

Jean Baudrillard.

Os contos de Tabucchi apresentam, de forma recorrente, procedimentos narrativos como o jogo literário e intertextual, a charada, a desconstrução do enredo, a fragmentação da narrativa, a subversão dos papéis tradicionais do narrador, dos personagens, do leitor, formas de representação que perturbam as bases da narrativa tradicional para propor novas regras e combinações ${ }^{62}$. De acordo com Filippo La Porta, estas características e procedimentos refletem o clima cultural da literatura dos anos de 1980, marcada e influenciada pelas obras de Italo Calvino e Umberto Eco, e por uma literatura que pode ser considerada "combinatoria, citazionistica e labirintica". Eco e Calvino são, na visão de La Porta:

\footnotetext{
"due autori molto diversi fra loro, anche solo sul piano temperamentale, ma entrambi capaci di offrire, al momento giusto, una versione divulgativa e in fondo aproblematica del postmoderno italiano, che influenzerà molti dei giovani narratori”, ${ }^{63}$
}

Tabucchi, por ser um escritor que se afirma neste período, é definido por grande parte da crítica como "pós-moderno" devido a sua prosa "metanarrativa, metatextual, ontológica", mas prefere se declarar "neorromântico" e recorda que muitas categorias reconhecidas como pós-modernas, são expedientes literários já utilizados pela literatura precedente ${ }^{64}$.

\footnotetext{
${ }^{62}$ Trentini, N. Una scrittura in partita doppia. cit., p. 17.

${ }^{63}$ La Porta, F. "Gli ultimi vent'anni: nuovi romanzi per nuovi lettori". In: Manuale di letteratura italiana: Storia per generi e problemi. Dall'Unità d'Italia alla fine del Novecento. Vol. 4. Turim: BollatiBoringhieri, 1996. pp. 619-620: "dois autores muito diferentes entre si, mesmo que apenas no plano temperamental, mas ambos capazes de oferecer, no momento certo, uma versão divulgadora e, no fundo, não problemática do pós-moderno italiano, que influenciará muitos dos jovens narradores".

${ }^{64}$ Trentini, N. Una scrittura in partita doppia. cit., p. 25.
} 
É um autor consciente de seu momento histórico e da consequente impossibilidade de se representar a realidade da forma em que esta se apresenta, nos moldes da narrativa tradicional, por isso, volta sua atenção para os espaços vazios que existem entre um fragmento de real e outro, para as fissuras que se abrem entre as coisas, transformando estas fissuras em motivo literário. Para Tabucchi, a razão e a lógica não podem contribuir para explicar uma realidade que se apresenta muitas vezes de forma ilógica e irracional, e por este motivo, sua escrita privilegia a representação das situações de fronteiras, dos estados alterados da consciência, dos sonhos, das reminiscências do passado que se sobrepõem ao presente narrado.

Um exemplo disso é o conto "Il gioco del rovescio", narrativa que dá nome ao livro e que inaugura a poética do fragmento - ou "dei buchi”, , conforme a mencionada expressão de Tabucchi -, constituindo-se uma narrativa "modelo", porque propõe esta poética. Narrativa circular que subverte a ideia de existência de uma realidade ordenada, lógica e coerente, apontando, ao invés, para a instabilidade e a oscilação do real, para a configuração de uma atmosfera onírica, plena de mistério. Nesta narrativa, o leitor é frequentemente tomado por uma sensação de que nada é certo e tudo resulta na impossibilidade de se chegar a uma verdade única, conclusiva.

O conto é centrado na figura dúbia de Maria do Carmo, uma mulher fascinante e evasiva, morta prematuramente, personagem por quem o narrador nutre admiração intelectual e sentimental e que faz de um jogo da infância, o "jogo do revés", um modo de conceber a arte e a vida. É através deste jogo que a relação entre o narrador e a figura enigmática de Maria do Carmo vai sendo construída.

Neste conto, a representação objetiva da realidade cede espaço a uma narrativa fragmentada, entrecortada pelo sonho, pelas lembranças de um passado que continua a agir sobre o narrador. Espaço e tempo se constroem de modo subjetivo: a visão da cidade de Lisboa é permeada pelo olhar do narrador que determina seu percurso pela cidade; o tempo passado e o presente são apresentados em dois planos temporais alternados e simultâneos, mostrando ao leitor a dificuldade do narrador de se desprender do passado e se fixar no presente.

Temos, assim, uma sobreposição de dois tempos narrativos: o primeiro, o do presente do narrador, quando este recebe a notícia da morte de Maria do Carmo e decide voltar à cidade de Lisboa; o segundo tempo narrado é aquele das lembranças do narrador, que retornam enquanto este faz a viagem de volta à cidade portuguesa. Deste 
modo, enquanto o narrador percorre a Lisboa do presente, percorre também aquela do seu passado e, aos poucos, vai se dando conta de que o que passou, de certa forma, torna-se vivo a cada lembrança, e é apenas nestes fragmentos de tempo que o narrador consegue reencontrar a si mesmo.

No início do conto, o narrador está observando o quadro Las meninas de Velázquez no Museu do Prado quando recebe a notícia da morte de Maria do Carmo:

\begin{abstract}
“Quando Maria do Carmo Meneses de Sequeira morì, io stavo guardando Las meninas di Velázquez al museo del Prado. Era un mezzogiorno di luglio e io non sapevo che lei stava morendo. Restai a guardare il quadro fino alle dodici e un quarto, poi uscii lentamente cercando di trasportare nella memoria l'espressione della figura di fondo, ricordo che pensai alle parole di Maria do Carmo: la chiave del quadro sta nella figura di fondo, è un gioco del rovescio",65
\end{abstract}

Depois disso, decide retornar a Lisboa e começa uma viagem de volta à cidade, ao seu passado, às suas lembranças e é tomado pela "saudade" que circunda não só a figura de Maria do Carmo, mas também toda a cidade portuguesa. A ideia de saudade, considerada pelo poeta Fernando Pessoa uma "categoria do espírito português", um sentimento existencial, é retomada por Maria do Carmo, quando esta apresenta a cidade ao narrador:

"La saudade non è una parola, è una categoria dello spirito, solo i portoghesi riescono a sentirla, perché hanno questa parola per dire che ce l'hanno, lo ha detto un grande poeta" 66

Para Stefano Tani, esta narrativa associa à ideia de revés como "consapevolezza del risvolto segreto e inaspettato della vita", a ideia de saudade, "la struggente malinconia per un altrove al di là del mare che diviene per i portoghesi 'categoria dello spirito', pervasivo sentimento esistenziale", pois quando o narrador evoca a personagem

\footnotetext{
${ }^{65}$ Tabucchi, A. "Il gioco del rovescio". In: Racconti. cit., p.13. "Quando Maria do Carmo Meneses de Sequeira morreu, eu estava olhando Las meninas de Velázquez no museu do Prado. Era um meio-dia de julho e eu não sabia que ela estava morrendo. Fiquei olhando o quadro até meio-dia e quinze, depois saí lentamente procurando transportar na memória a expressão da figura de fundo; lembro que pensei nas palavras de Maria do Carmo: a chave do quadro está na figura de fundo, é um jogo do reverso".

${ }^{66}$ Tabucchi, A. "Il gioco del rovescio". cit., p. 14: "A saudade não é uma palavra, é uma categoria do espírito, somente os portugueses conseguem senti-la porque têm esta palavra para dizer que a têm, disse um grande poeta".
} 
de Maria do Carmo, "riaffiorano e si fondono il mistero della sua intensa personalità e la malinconia per la sua scomparsa"; revés e saudade, duas categorias que se transformam em técnicas narrativas e dois elementos essenciais da voz narrativa e da postura existencial do escritor ${ }^{67}$.

Maria do Carmo, mulher de um diplomata português, adepto do governo salazarista, ajudava escritores contrários ao regime ditatorial, presos em Portugal. O narrador a conhece quando vai a Lisboa em missão de solidariedade proposta por colaboradores de partidos democráticos italianos. No encontro com Maria do Carmo, ela lhe mostra Lisboa, conta sobre sua infância pobre em Buenos Aires, onde a família tinha sido exilada e fala também sobre o poeta Fernando Pessoa. Anos depois, com a morte de Maria do Carmo, o narrador encontra o marido dela que lhe entrega uma carta deixada pela mulher. O diplomata lhe conta que Maria do Carmo era filha de grandes proprietários portugueses e que ela, assim como ele, o marido, sempre tinha sido favorável ao regime ditatorial português, insinuando que a mulher conhecida pelo narrador era apenas uma ficção, um "revés" da verdadeira Maria do Carmo.

Desta forma, o narrador, ao mesmo tempo em que lança uma dúvida sobre qual seria a "verdadeira" personalidade de Maria do Carmo, também é atingido por essa ambiguidade. A carta recebida, na qual estava escrita apenas a palavra SEVER, reverso da palavra REVES, retoma o jogo da infância de Maria do Carmo, o juego del revés, jogo que, ao mostrar o reverso das palavras, revela também um ponto de vista novo sobre elas. Este jogo não é só o mote condutor da narrativa, como também uma importante metáfora interpretativa ligada não apenas aos nomes, ao ponto de vista sobre as coisas e as situações da vida, mas que se relaciona diretamente com o sentimento narrativo do tempo ${ }^{68}$, ou seja, instaura uma possibilidade de reversão do tempo.

E é assim que a carta com a palavra SEVER "rovesciata” lança, também, um fragmento de certeza em meio às incertezas do narrador. No final, o narrador consegue reencontrar a mulher em um sonho. Neste, o quadro de Velázquez é a peça importante que o ajuda a entender e talvez a se reconciliar com a figura dúbia de Maria do Carmo:

\footnotetext{
${ }^{67}$ Tani, S. Il romanzo di ritorno. cit., p. 155: "consciência do viés secreto e inesperado da vida"; "a pungente melancolia por um alhures do além-mar que se torna 'categoria do espírito' para os portugueses, sentimento existencial penetrante"; "ressurgem e se fundem o mistério da sua intensa personalidade e a melancolia pela sua morte".

${ }^{68}$ Palmieri, Giovanni. "Per una volatile leggerezza: il 'lato manco' di Antonio Tabucchi". In: Piccole finzioni con importanza. Valori della narrativa italiana contemporanea. Org. Nathalie Roelens e Inge Lanslots. Ravenna: Longo Editore, 1991. pp. 125-136.
} 
"Forse Maria do Carmo aveva finalmente raggiunto il suo rovescio. Le augurai che fosse come lo aveva desiderato e pensai che la parola spagnola e quella francese forse coincidevano in un punto. Mi parve che esso fosse il punto di fuga di una prospettiva, come quando si tracciano le linee prospettiche di un quadro, in quel momento la sirena fischiò un'altra volta, la nave attraccò, io scesi lentamente dalla passerella e cominciai a seguire i moli, il porto era completamente deserto, i moli erano le linee prospettiche che convergevano verso il punto di fuga di un quadro, il quadro era Las meninas di Velázquez, la figura di fondo sulla quale convergevano le linee dei moli aveva quell'espressione maliziosa e malinconica che mi ero impresso nella memoria: e che buffo, quella figura era Maria do Carmo con il suo vestito giallo, io le stavo dicendo: ho capito perché hai codesta espressione, perché tu vedi il rovescio del quadro, che cosa si vede da codesta parte? Dimmelo, aspetta che vengo anch'io, ora vengo a vedere. E mi incamminai verso quel punto. $\mathrm{E}$ in quel momento mi trovai in un altro sogno" ${ }^{99}$.

Como vemos, o autor parte da referência ao quadro Las meninas de Velázquez e a ela retorna na conclusão do conto. A referência ao quadro, feita logo no início e depois no final, fechando o conto, ou melhor, apontando para a circularidade da narrativa, funciona também como uma espécie de mise en abyme dentro da narrativa: uma referência que emoldura o conto ao mesmo tempo em que o conto contém a referência ao quadro, em um efeito de espelhamento, como se o conto espelhasse o quadro, ao mesmo tempo em que é espelhado por este. Com este trecho final, Tabucchi coloca em discussão a questão da representação dentro da representação e retoma a pergunta feita por muitos intérpretes do quadro de Velázquez: "o quê vê a figura de fundo no quadro"? E a resposta a esta pergunta é também a resposta sobre o próprio significado do conto:

\footnotetext{
${ }^{69}$ Tabucchi, A. "Il gioco del rovescio". In: Racconti. cit., p. 24: "Talvez Maria do Carmo tivesse finalmente alcançado o seu reverso. Desejei-lhe que fosse como o tinha esperado e pensei que a palavra espanhola e a francesa talvez coincidissem em um ponto. Pareceu-me que esse fosse o ponto de fuga de uma perspectiva, como quando se traçam as linhas de perspectiva de um quadro, e naquele momento a sirene tocou outra vez, o navio atracou, eu desci lentamente pela passarela e comecei a seguir as docas, o porto estava completamente deserto, as docas eram as linhas de perspectiva que convergiam em direção ao ponto de fuga de um quadro, o quadro era Las meninas de Velázquez, a figura de fundo para a qual convergiam as linhas das docas tinha aquela expressão maliciosa e melancólica que eu tinha gravado na minha memória: e que engraçado, aquela figura era Maria do Carmo, com o seu vestido amarelo, e eu lhe dizia: entendi porque tem esta expressão, porque você vê o revés do quadro, o que se vê desta parte? Diga-me, espera que vou também, vou ver agora. E me dirigi em direção àquele ponto. E naquele momento me encontrei em outro sonho".
} 
"la chiave del quadro sta nella figura di fondo, è un gioco del rovescio"70. Ou seja, a chave de leitura do texto é, no fim das contas, o que nos leva de volta ao seu início, é a palavra "revés" escrita ao contrário, um jogo de espelhos em que o início e o fim convergem para um mesmo ponto de fuga.

Michel Foucault, em As palavras e as coisas $^{71}$, afirma que aquilo que a figura de fundo, o cortesão, do quadro de Velázquez vê, na sua "clara profundidade", é o invisível. Se pensarmos de maneira análoga, também o conto tabucchiano aponta para aquilo que é invisível ou que não está aparente, assemelhando-se à pintura. No sonho do narrador, Maria do Carmo alcança o ponto de fuga das linhas de perspectiva e consegue ver aquilo que existe do outro lado do quadro: alcança o seu revés e consegue ver aquilo que é invisível aos olhos de um observador habituado à lógica de uma realidade concreta, claustrofóbica, sem pontos de fuga.

Deste modo, o conto contraria a ideia de uma interpretação única, equívoca e fechada, apontando, ao invés disso, para uma lógica do possível, da multiplicidade de perspectivas, em que a "chave" para entendimento do texto está "além-texto", e a possibilidade de compreensão da trajetória de Maria do Carmo está além dos acontecimentos da realidade visível, concreta e incongruente.

Tabucchi rompe, assim, com o pacto narrativo, pois consegue representar "l'irriducibile estraneità, la densità non assimilabile del reale",72, correndo o risco, porém, de que o leitor se perca nos vãos do processo de leitura e decodificação do texto literário:

\footnotetext{
"Quando si confezionano racconti in cui tutto, a cominciare dal sogno, sembra essere reversibile, o si esagera nell'uso degli specchi, il lettore è tentato di lasciare perdere modi e moventi del nodo di paradossi che si ritrova tra le mani, saltando immediatamente alla non inedita conclusione che la vita è sogno, e dunque tutto è inconoscibile e uguale a tutto" ${ }^{, 73}$.
}

\footnotetext{
${ }^{70}$ Tabucchi, A. "Il gioco del rovescio". cit., p. 13: "a chave do quadro está na figura de fundo, é um jogo do reverso".

${ }^{71}$ Foucault, Michel. As palavras e as coisas. Uma arqueologia das ciências humanas. Trad. Salma T. Muchail. São Paulo: Martins Fontes, 2002

${ }^{72}$ Amigoni, F. Fantasmi nel Novecento. Turim: Bollati Boringhieri Editore, 2004. p. 138: "o irreduzível estranhamento, a densidade não assimilável do real”.

${ }^{73}$ Amigoni, F. Fantasmi nel Novecento. cit, p. 135: "Quando se confeccionam contos em que tudo, a começar pelo sonho, parece ser reversível, ou se exagera no uso dos espelhos, o leitor é tentado a deixar para lá modos e motivos do nó de paradoxos que encontra entre as mãos, saltando imediatamente para a não inédita conclusão de que a vida é sonho e, portanto, tudo é incognoscível e igual a tudo".
} 
Como dissemos, o procedimento circular de construção da narrativa contraria a perspectiva de uma interpretação única e aponta para uma lógica do reversível e da multiplicidade de perspectivas. O que podemos concluir é que diante da impossibilidade de se explicar uma realidade enigmática, a narrativa se estrutura de modo fragmentário, entrecortada por elementos como o sonho, a imaginação, as reminiscências do narrador, elementos que, de acordo com Bakthin em seu estudo sobre a poética de Dostoiéviski, introduzem uma "situação de exceção" na lógica da narrativa. Esta situação excepcional destrói a unidade da vida representada e cria planos formais secundários, que são regidos por leis diferentes, postulando no fazer narrativo um "mundo às avessas". Temse, assim, a impossibilidade de uma forma orgânica e unitária, já que a matéria de que se trata é informe, múltipla, plena de nuances ${ }^{74}$.

Com "Il gioco del rovescio", Tabucchi instaura uma poética que opera com a identificação total entre "rovescio" e sonho, já que a palavra "reves", escrita na carta de Maria do Carmo, remete, duplamente, à palavra revés em espanhol e rêves, em francês, reverso e sonho(s). Assim, a tentativa de encontrar um sentido, um desfecho que traga alguma certeza ao narrador, e consequentemente ao leitor, permanece em suspenso ou é confiada ao sonho:

\footnotetext{
"All'impossibilità di una comprensione o decifrazione immediata dell'esistenza si sostituisce il dubbio, la costante interrogativa quale unica e parodossale interpretativa. La ricerca di un senso soppianta la categoria della certezza originando percorsi incongrui, labirintici, e si afferma come unica risposta possibile" 75 .
}

Desta forma, a presença do sonho subverte a ordem das coisas, instaura uma lógica da escassez de sentido, em que predominam a porosidade dos limites, a fluidez das fronteiras entre real e irreal, a alternância entre realidade e ficção, tornando frágil a distinção entre o real e o imaginado.

\footnotetext{
${ }^{74}$ Bakhtin, M. M. Problemas da poética de Dostoiéviski. 5a. ed. Trad. Paulo Bezerra. Rio de Janeiro, Forense Universitária, 2010. p. 169.

${ }^{75}$ Trentini, N. Una scrittura in partita doppia. cit., p. 38. Nota. "À impossibilidade de uma compreensão ou decifração imediata da existência se substitui a dúvida, a constante da interrogação como única e paradoxal [constante] da interpretação. A busca de um sentido suplanta a categoria da certeza originando percursos incongruentes, labirínticos, e se afirma como única resposta possível".
} 


\title{
2.3. O TEMPO REVERSÍVEL DA MEMÓRIA
}

"Per la verità io non ho ancora ben capito se siamo noi che attraversiamo il tempo o se è il tempo che ci attraversa".

Antonio Tabucchi.

Como vimos, "Il gioco del rovescio" apresenta como temática o revés, o avesso das coisas, a saudade, temas que se colocam como chave de leitura do conto e pressupõem, na forma, o jogo literário, a desconstrução do enredo, os percursos incongruentes, a fragmentação da narrativa:

\begin{abstract}
"Che cosa sono infatti i percorsi incongrui, gli equivoci, il mistero, i rebus che affollano parte della narrativa tabucchiana se non un espediente per mettere il lettore di fronte a una realtà sfuggente, labirintica, misteriosa, che metaforicamente costruisce l'immagine del mondo contemporaneo? Il mondo della pagina si fa immagine di quello reale, la perdita di certezze dei personaggi investe il lettore e lo costringe a porsi dei quesiti’ ${ }^{, 76}$.
\end{abstract}

Tabucchi possui, de acordo com Brizio-Skov, uma tendência a ver o mundo "dal rovescio", os personagens olham o mundo a partir de uma perspectiva insólita:

'Il 'rovescio' è una prospettiva che sfugge ai personaggi di questo mondo
narrativo come al lettore: nella nostra vita quotidiana e reale siamo anche noi
affliti dall'incapacità di avere risposte. Il caso, il rebus, l'equivoco, il mistero
sono diramazioni della categoria filosofica del 'rovescio'. (...) l'impossibilità
di dare chiusura definitiva al racconto letto conferma la molteplicità delle

\footnotetext{
${ }^{76}$ Brizio-Skov, F. Antonio Tabucchi: navigazioni in un arcipelago narrativo. cit., p.18: “O que são, de fato, os percursos incongruentes, os equívocos, o mistério, os rebus que povoam parte da narrativa tabucchiana se não um expediente para colocar o leitor diante de uma realidade fugidia, labiríntica, misteriosa, que constrói metaforicamente a imagem do mundo contemporâneo? O mundo da página se torna imagem daquele real, a perda das certezas dos personagens atinge o leitor e o obriga a colocar-se algumas perguntas".
} 
verità, delle risposte e ci toglie quel senso finito, concluso, sicuro, irremovibile, aumenta la perdita delle nostre certezze" 77 .

Assim, o "rovescio" e sua consequente expressão formal configuram uma poética, um fazer literário, uma categoria não só narrativa, mas, como assinala BrizioSkov, filosófica. Como categoria, o revés também introduz uma discussão da própria concepção de literatura, que não raro se desdobra em metaliteratura, englobando, por vezes, nessa discussão, o próprio leitor, no momento em que este recebe do texto literário "pistas falsas", seja sobre o sentido aparente da escrita, seja sobre o significado mais profundo do texto lido.

A narrativa tabucchiana parece empreender um "reconhecimento da literatura como forma de compreender a indefinição do mundo e do homem" ${ }^{\text {78 }}$, por meio da subversão da ideia de existência de um universo racional, ordenado, lógico e coerente, apontando, em vez disso, para a instabilidade e a oscilação do real, para a configuração do misterioso e do fantástico, para o sonho como horizonte de perspectivas, para uma poética da desconstrução e do fragmento. Na década de 1980, esta tendência da literatura tabucchiana está em processo de constituição e de afirmação, de modo que este período se caracteriza por uma "centralização do onírico e do fantástico",79 , por uma forte presença do sonho como elemento não apenas temático, mas estrutural. O sonho é:

"il mezzo atto a dare spessore al passato mescolandolo col presente e ad arricchire il presente gravandolo della consapevolezza dell'immutabile. Il sogno e l'insonnia sono quanto, nella vita cosiddetta reale, appare più libero dai freni inibitori dell'io, dalle leggi esterne della temporalità radicale" ${ }^{\prime 80}$.

\footnotetext{
${ }^{77}$ Brizio-Skov, F. Antonio Tabucchi: navigazioni in un arcipelago narrativo. cit., pp. 18-9: “O 'reverso' é uma perspectiva que escapa aos personagens deste mundo narrativo assim como ao leitor: na nossa vida quotidiana e real, nós também ficamos aflitos pela incapacidade de ter respostas. $\mathrm{O}$ caso, o rebus, o equívoco, o mistério são ramificações da categoria filosófica do 'reverso'. (...) a impossibilidade de fechar definitivamente o conto lido confirma a multiplicidade das verdades, das respostas e nos tira aquele sentido de acabado, concluído, seguro, inflexível, aumenta a perda das nossas certezas".

${ }^{78}$ Pinto, J. Pimentel. "A literatura do desassossego". In: EntreLivros, julho de 2006. Ano 2, No.15. São Paulo: Ediouro. p. 64.

${ }^{79}$ Trentini, N. Una scrittura in partita doppia. cit., p. 59.

${ }^{80}$ Dolfi, Anna. Tabucchi: la specularità, il rimorso. cit., p. 21-2: “o meio apropriado para dar espessura ao passado, misturando-o ao presente, e a enriquecer o presente onerando-o com a consciência do imutável. O sonho e a insônia são naquilo que na vida, chamada real, parece mais livre dos freios inibidores do eu, das leis externas da temporalidade radical".
} 
Para Tabucchi, o sonho se apresenta, muitas vezes, como única solução possível aos enigmas e enganos insolúveis que a vida apresenta:

\begin{abstract}
"A volte una soluzione sembra plausibile solo in questo modo: sognando. Forse perché la ragione è pavida, non riesce a riempire i vuoti fra le cose, a stabilire la completezza, che è una forma di semplicità, preferisce una complicazione piena di buchi, e allora la volontà affida la soluzione al sogno" ${ }^{\prime 1}$.
\end{abstract}

Além do sonho, o tempo e a memória também constituem uma temática importante em Il gioco del rovescio. A memória não é simplesmente um fato estático e repetitivo, mas consiste em um "ricordo [che] può venire falsato dal nostro modo di viverlo, dal nostro modo di vedere, dal nostro modo di pensare e, soprattutto, dal nostro modo di sentire" ${ }^{, 82}$. A memória aparece sempre contaminada de emoções, dilatando-se com o passar do tempo, gerando desejos que se voltam para um futuro, um futuro feito muitas vezes de passado.

No conto "Voci", como visto anteriormente, uma mulher solitária e abandonada pelo companheiro atende telefonemas de pessoas desconhecidas e desesperadas, mas quando volta para casa, precisa lidar com a própria solidão e desespero, e apega-se às recordações da vida passada com o ex-companheiro. A ilusão de que ele possa voltar a qualquer momento, representada pela mesa sempre posta, e a espera por uma realidade que possa superar a imaginação - "a volte la realtà supera l'immaginazione" 83 -, são os detalhes que dão sentido à sua vida e preenchem a monotonia do cotidiano.

Para o narrador tabucchiano, entretanto, uma realidade "melhor" existe apenas como desejo, imaginação, sonho ou memória: a realidade passada é sempre melhor do que realmente foi, porque a memória possui estatuto de "falsificadora", pois transforma os acontecimentos, dando-lhes outro significado de acordo com o tempo em que se

\footnotetext{
${ }^{81}$ Tabucchi, A. "Rebus”. In: Racconti. cit, p.149: “Às vezes uma solução parece plausível apenas deste modo: sonhando. Talvez, por ser pávida, a razão não consiga preencher os vazios entre as coisas, estabelecer a plenitude, que é uma forma de simplicidade e prefira uma complicação cheia de buracos e, então, a vontade confia a solução ao sonho".

${ }^{82}$ Tabucchi, A. Notturno Indiano. Palermo: Sellerio, 1984. p. 80. "uma lembrança que pode vir falsificada por nossa maneira de vivê-la, por nossa maneira de ver, por nossa maneira de pensar, e, sobretudo, por nossa maneira de sentir".

${ }^{83}$ Tabucchi, A. "Voci”. In: Racconti. cit., p.121: "às vezes, a realidade supera a imaginação".
} 
recorda: "La realtà passata è sempre meno peggio di quello che fu effettivamente: la memoria è una formidabile falsaria" ${ }^{, 4}$.

Nesse sentido, pode-se falar em fantasmas da memória que se multiplicam em possibilidades e desejos não realizados, que trazem para a realidade o sentido de um acontecimento vivido para então questioná-lo, interpretá-lo e reaproveitá-lo para a experiência presente. Estes fantasmas são representantes de um tempo ido, tempo que o narrador tabucchiano tenta reter, evocando-o, questionando-o, fixando-o nos pequenos detalhes, nas pequenas lembranças, mas o tempo é traiçoeiro e sempre escapa: "Il tempo è perfido, ci fa credere di non passare mai, e se guardiamo indietro è passato troppo in fretta" 85 .

Esta percepção do tempo está presente no conto "Il gioco del rovescio", em que o narrador não consegue se libertar das lembranças e da saudade da mulher amada. Cada passo que dá pela cidade de Lisboa traz para o presente narrado os cheiros, os sabores, os sons e os percursos traçados em um passado distante. Estas lembranças se apresentam na narrativa em um plano temporal paralelo, mas por vezes são tão vivas que se confundem com os acontecimentos do presente narrado. Ao relembrar o tempo passado, o narrador expressa seu desejo de retorno, de "revés". Mas este desejo projeção em relação ao futuro - o leva sempre de volta ao passado, e faz com que o acontecido nunca se feche, retornando como lembrança e sonho.

O tempo na narrativa de Tabucchi é linear, é portador do irreversível, transcorre inexoravelmente, e como não se pode deter o correr dos fatos, o narrador permanece aprisionado à memória do vivido, aos objetos passados, aos fragmentos relembrados, a um desejo de "correção do vivido". Neste sentido, Tabucchi faz notar que a literatura atua a partir da consciência da irreversibilidade do tempo passado, daquilo que existiu e existe, frequentando o lugar/tempo simbólico do irreversível, daquilo que foi condenado a não retornar e a não existir mais ${ }^{86}$ :

\footnotetext{
${ }^{84}$ Tabucchi, A. Notturno Indiano. cit, p. 80: "A realidade passada é sempre menos pior do que foi efetivamente: a memória é uma formidável falsária".

${ }^{85}$ Tabucchi, A. "Il piccolo Gatsby". In: Racconti. cit., p..81. "O tempo é pérfido, nos faz acreditar que não passa nunca, e se olhamos para trás, passou rápido demais".

${ }^{86}$ Dolfi, Anna. Gli oggetti e il tempo della saudade. cit,. p. 24.
} 
"Se la vita potesse tornare ad essere diversa da quella che è stata, annullerebbe il tempo e la successione delle cause e degli effetti che sono la vita stessa; e ciò sarebbe assurdo" ${ }^{87}$.

O efeito inexorável do tempo sobre as coisas é, de acordo com Ceserani ${ }^{88}$, uma das temáticas recorrentes na obra de Tabucchi e está relacionada com a memória que, na tentativa de manter vivo o passado, torna-se fluida, líquida. De acordo com o estudioso, na literatura tabucchiana a memória frequentemente é vista como "un getto liquido che sgorga da una sorgente nascosta in un anfratto profondo dell'essere e comincia a gocciolare" ${ }^{, 89}$. A memória, nos contos de Tabucchi, é plena de emoções, e com o passar dos anos, torna-se cada vez mais elástica e flexível. É ela que transforma os acontecimentos, dando-lhes novos significados, de acordo com o tempo em que aquele que recorda vive.

O conto "Il gatto dello Cheshire", incluído na segunda edição de Il gioco del rovescio, de 1988, pode ilustrar bem a presença deste tema. O conto dialoga com a obra de Lewis Carrol, Alice do país das maravilhas, uma vez que se utiliza dos nomes dos personagens de Carrol para carcterizar e atribuir uma personalidade às figuras ali representadas: Alice e o gato do Cheshire. O protagonista é um típico personagem tabucchiano: aprisionado ao passado, às lembranças de um passado que não se conclui, pois os fatos não "se encaixam". Como muitos personagens dos contos tabucchianos, tem a "subterrânea sensação" de estar atrasado em relação à vida, e em relação a si mesmo. É um representante daquilo que Tabucchi chama, a propósito dos personagens de Si sta facendo sempre più tardi, romance epistolar, publicado em 2001, de "vite fuori orario":

I [miei] personaggi hanno la sotterranea sensazione di essere in ritardo, anche su se stessi. Oppure a volte hanno la sensazione di essere stati in anticipo o di

\footnotetext{
${ }^{87}$ Tabucchi, A. "Passato composto. Tre lettere". In: I volatili del Beato Angelico. 10a. ed. Palermo: Sellerio Editore, 2005. p. 31. Ed. Bras. Os Voláteis do Beato Angélico. Trad. Ana Lúcia R. Belardinelli. Rio de Janeiro: Rocco, 2003: "Se a vida pudesse voltar a ser diversa daquilo que foi, anularia o tempo e a sucessão das causas e dos efeitos que são a própria vida; e isto seria absurdo".

${ }^{88}$ As referências a Ceserani são retiradas, sobretudo, de seu livro Raccontare il postmoderno. (Turim: Bollati Boringhieri Editore, 1997), entretanto algumas considerações sobre a poética tabucchiana e sua inserção na pós-modernidade literária italiana nos foram sugeridas durante curso sobre a Pósmodernidade ou Modernidade líquida na Itália, ministrado em outubro de 2010, na FFLCH/USP.

${ }^{89}$ Ceserani, R. "Qualche considerazione sulla modernità liquida". In: La modernità letteraria. Pisa/Roma: Fabrizio Serra Editore, 2010. p. 20: "um jato líquido que brota de uma nascente escondida num desfiladeiro profundo do ser e começa a gotejar".
} 
essere stati in ritardo nel senso che avevano intuito ciò che stava loro succedendo: tradimenti fatti o subiti, errori e incomprensioni, solo che se ne sono accorti in ritardo. Nel senso che sul momento intuivano ma non capivano; hanno capito dopo. Insomma, sono vite fuori orario" 90 .

Em "Il gatto dello Cheshire", assim como em "Il gioco del rovescio", temos um personagem que vai ao encontro de uma mulher (ou da imagem desta) que conhecera no passado e da qual havia tempos não tinha notícias. É a retomada de uma história não resolvida. $\mathrm{O}$ encontro no presente não acontece e se revela, no final, uma brincadeira, um jogo do acaso. O final da narrativa permanece aberto, suspenso, como em várias outras narrativas de Tabucchi. O narrador, em primeira pessoa, é protagonista e, ao retornar a casa, encontra uma estranha mensagem na secretária telefônica. Esta mensagem se revela uma espécie de assombração, uma fantasmagoria do passado, que evoca um acontecimento vivido há muito tempo, mas ainda presente na memória do narrador. Uma mulher com quem ele havia tido uma relação sentimental no passado e que, após muitos anos desaparecida, telefona e marca um encontro para o dia seguinte: "dopodomani quindici luglio alle ore quindici, stazione di Grosseto, ti aspetterò al binario" $" 91$.

O narrador, sem entender muito bem o sentido do telefonema, pega o trem em direção a Grosseto, para reencontrar a mulher do passado, identificada na narrativa com o apelido de Alice. No passado, os personagens jogavam um jogo, encenando os papéis de Alice e do gato de Cheshire, uma clara referência aos personagens de Carrol: "tutto un divertimento, come una bella storia"92, engolida, entretanto, pelo passar dos anos, pois:

\footnotetext{
${ }^{90}$ Tabucchi, A. Autobiografia altrui. cit., p. 87: “Os [meus] personagens têm a sensação subterrânea de estarem atrasados, também sobre si mesmos. Ou então, às vezes, têm a sensação de terem sido antecipados ou atrasados, no sentido que intuíram o que lhes estava acontecendo: traições cometidas ou sofridas, erros e incompreensões, só que perceberam isso com atraso. No sentido que, na hora, intuíam mas não entendiam. Entenderam depois. Resumindo, são vidas fora de horário".

${ }^{91}$ Tabucchi, A. "Il gatto dello Cheshire". In. Racconti. cit., p. 371: "depois de amanhã, quinze de julho, às quinze horas, estação de Grosseto, vou te esperar na plataforma”.
}

${ }^{92}$ Tabucchi, A. "Il gatto dello Cheshire". cit., p. 372: "tudo uma diversão, como uma bela história". 
"nel frattempo il gatto era scomparso, proprio come nel libro. Chissà che non fosse rimasto il sorriso, ma il sorriso solo, senza il volto che era padrone di quel sorriso" ${ }^{, 93}$.

O narrador reflete sobre o tempo passado, que "divora le cose" - devora as coisas - e depois as faz reaparecer na memória através de uma lembrança, um acontecimento qualquer, um sonho, um objeto, um telefonema fantasmagórico. Decide iniciar uma viagem para reencontrar este "tempo perdido", retomar uma história perdida no tempo, no escorrer do tempo, que ao passar, arrasta consigo todas as coisas. A viagem se torna, então, uma tentativa de lutar contra o esquecimento, voluntário e/ou involuntário, já que o tempo age de maneira contínua, tentando cancelar tudo o que passou, enquanto a memória se esforça para manter vivas as lembranças e assim perpetuar o passado.

Como em "Il gioco del rovescio", o narrador desliza no tempo, entre presente narrativo e passado recordado, numa alternância temporal que gera uma narrativa cheia de fissuras, saltos, retornos, divagações. O passado impede o narrador de organizar sua vida presente, pois faz com que ele permaneça aprisionado no tempo, perdido na memória de um caso não resolvido, sem solução aparente, desprovido de sentido:

\footnotetext{
"questa cosa non ha senso. Ma perché, le cose hanno un senso? Forse sì, ma un senso segreto, si capisce poi, molto più tardi, o non si capisce, ma devono avere un senso: un senso loro, certo, che a volte non ci riguarda, anche se sembra di sì" 94 .
}

Perdido nestas divagações e lembranças, sem entender o sentido do recado telefônico, o narrador deixa passar a estação de Grosseto, percebendo o ocorrido somente quando era tarde demais: tenta voltar, mas se dá conta que havia perdido o encontro e que era inútil tentar entender as coisas. O tempo se torna o único consolo:

\footnotetext{
${ }^{93}$ Tabucchi, A. "Il gatto dello Cheshire". cit., p. 372: "no meio tempo, o gato desapareceu, exatamente como no livro. Quem sabe não tivesse restado o sorriso, mas só o sorriso, sem o rosto que era dono daquele sorriso".

${ }^{94}$ Tabucchi, A. "Il gatto dello Cheshire". cit., p. 371: "isto não tem sentido. Mas porque, as coisas têm um sentido? Talvez sim, mas um sentido secreto, só se entende depois, muito depois, ou não se entende, mas devem ter um sentido: um sentido próprio, claro, que às vezes não nos diz respeito, mesmo que pareça que sim".
} 
"È impossibile ormai non solo raggiungere gli altri ma anche se stessi; è inutile tornare indietro. Non resta che il tempo (...) per la prosecuzione di un viaggio ormai senza meta" ${ }^{95}$.

O encontro perdido, "l'appuntamento mancato", é um dos jogos do acaso recorrentes na narrativa tabucchiana. $\mathrm{O}$ autor cria desencontros, acasos fortuitos, aproxima e afasta personagens, mostrando os "pequenos equívocos sem importância" que constituem o destino humano. Esta temática aparece, em muitos de seus contos, associada ao tema do fantástico, a uma presença perturbante relacionada ao passado dos personagens.

O conto "Il gatto dello Cheshire" deixa em aberto o sentido do telefonema, assim como deixa em suspenso o final da narrativa, procedimento comum a muitos contos do autor. A suspensão do final nos faz pensar que até mesmo o recado na secretária telefônica pode ter sido apenas imaginado pelo protagonista, "uma vaga projeção mental", vinda "de um mundo morto" 96 . Talvez fantasmas da memória tentando trazer para a realidade um acontecimento vivido, mas que não se concluiu no passado, deixando vivos na lembrança sentimentos de culpa e de remorso, que impedem o personagem de seguir adiante.

A evocação do passado, a presença fantasmagórica de uma mulher do passado que, no entanto, não se materializa, mas age como uma aparição, uma sombra fugidia, sugere que o conto tenta estabelecer um laço entre o real e o universo do fantástico. Como escritor acostumado a conviver com as "aporias do pensamento lógico e as epifanias do informe" ${ }^{\prime 97}$, Tabucchi se utiliza de processos e mecanismos que trazem para os seus contos a ótica do fantástico. Ceserani considera alguns destes procedimentos utilizados por Tabucchi como uma forma de revisitação do fantástico na narrativa contemporânea, já que se utiliza, por exemplo, da modalidade comunicativa da conversação à distância, valendo-se do telefone como objeto mediador entre o protagonista e um fantasma ${ }^{98}$.

\footnotetext{
${ }^{95}$ Dolfi, A. Gli oggetti e il tempo della saudade. cit., p. 34: "Agora é impossível não apenas alcançar os outros mas também a si mesmo; é inútil voltar atrás. Não resta nada mais que o tempo (...) para o prosseguir de uma viagem, por hora, sem meta".

${ }^{96}$ Dolfi, A. Gli oggetti e il tempo della saudade. cit., p. 34.

${ }^{97}$ Amigoni, F. Fantasmi nel Novecento. cit., p. 126.

${ }^{98}$ Ceserani, R. "Qualche considerazione sulla modernità liquida". In: La modernità letteraria. cit., p. 19: "un esempio di rivisitazione postmoderna del fantastico perchè utilizza la modalità comunicativa della conversazione a distanza tramite il telefono per istituire un rapporto fra il mondo naturale e quello che si
} 
E o sorriso que fica no ar, sem o gato, a essência do gato de Cheshire, proposta por Carrol, anuncia que o que permanece é a sensação causada por aquela presença, sem a presença em si. Outro indício do fantástico, evocada e sugerida, todavia, pelo intertexto narrativo.

Outro exemplo de narrativa que se aproxima do universo do fantástico em Il gioco del rovescio é o conto "I pomeriggi del sabato", no qual temos um narrador que recorda o tempo da infância, quando tentava suprimir a dor da perda do pai com o estudo do latim. A lenta sucessão e repetição dos dias cede espaço a um evento absurdo que rompe com o sentido e a percepção do real: a irmã menor do narrador, Nena, vê, numa tarde de sábado, a figura inquietante de um homem de bicicleta:

\footnotetext{
"Era in bicicletta, disse la Nena, aveva in testa un fazzoletto con i nodi, l'ho visto bene, anche lui mi ha visto, voleva qualcosa qui di casa, l'ho capito, ma è passato come se non potesse fermarsi, erano le due precise" ${ }^{\text {"99 }}$.
}

Esta aparição se repetirá nos dois sábados seguintes, sempre na mesma hora, e no quarto sábado, a presenciar a passagem da estranha figura será a mãe. O narrador não vê nunca o fantasma, mas sente a sua forte presença. No intervalo de tempo, no correr da semana, o menino estuda latim, tentando se consolar da ausência e da perda do pai, e fugir da presença perturbadora que visita a família.

O cenário e a ambientação do conto são, por sua vez, domésticos, dotados de dados realísticos que contrastam com o fato perturbante que o menino se recusa a aceitar: a presença do fantasma do pai. O estudo disciplinador do latim é utilizado como refúgio para escapar da angústia que as palavras da irmã lhe provocavam. Pode-se dizer que este tipo de ambientação realística da narrativa é, de acordo com Amigoni, necessidade do universo do fantástico, que se alimenta da concretude, da profundidade ilusória de um cenário verossímil:

presenta come sovrannaturale. Il telefono agisce da vero oggetto mediatore, che introduce il possibile rapporto fra il protagonista e un fantasma".

${ }^{99}$ Tabucchi, A. "I pomeriggi del sabato". In: Racconti. cit., p. 53: "Estava de bicicleta, disse a Nena, tinha, na cabeça, um lenço com os nós, eu o vi direito, ele também me viu, queria alguma coisa aqui de casa, isso eu entendi, mas passou como se não pudesse parar, eram duas horas exatamente". 
"Il fantastico necessita di concretezza, della profondità illusoria di uno scenario verosimile. Che si riveli poi capace di rappresentare l'atroce reale della storia con insospettata forza iconica" ${ }^{\prime 100}$.

A ausência do pai - ausência inclusive da palavra "pai”, que aparece poucas vezes no conto, sempre associada às memórias do menino - preenche todo o espaço narrativo, cria uma atmosfera de suspensão temporal, impede a continuidade da vida e a elaboração do luto:

\begin{abstract}
"Cercato, desiderato, allucinato, il padre assente è una figura centrale della scrittura di Tabucchi, reperibile in molti romanzi e racconti (...). Capita infatti, Freud lo ricorda in più di un luogo, che il padre assente si trasformi nei migliori dei casi in un Super-Io, tanto più severo, quanto più inafferrabile, mentre nel peggiore chiude al soggetto ogni via d'accesso al simbolico" ${ }^{101}$.
\end{abstract}

A presença do fantasma do pai morto - e a consequente instauração de um universo fantástico - está presente como temática em várias obras de Tabucchi. O encontro com o fantasma do pai morto é, por exemplo, um dos encontros principais do narrador protagonista do romance Requiem. Nos contos "Gli incanti", de Piccoli equivoci senza importanza e no conto "Capodanno", de L'Angelo Nero, a ausência do pai produz fantasmagorias que determinam e transformam a vida dos personagens, também crianças, ali representados. São personagens vítimas do luto, que sofrem de "afasias e psicoses", lidam com a perda e o silêncio, com a "perdita della distinzione tra linguaggio e referente"; na forma, são obras que colocam em dúvida "l'inviolabilità delle frontiere che separano i vivi dai morti"102.

Outro mecanismo interessante que remete ao universo do fantástico é, de acordo com Ceserani ${ }^{103}$, a presença de um objeto mediador entre o universo do real e o fantasmagórico: em "Il gatto dello Cheshire", como vimos, o objeto que faz a mediação

\footnotetext{
${ }^{100}$ Amigoni, F. Fantasmi nel Novecento. cit., p. 125: "O fantástico necessita de concretude, da profundidade ilusória de um cenário verossímil. Que se revele, depois, capaz de representar a atroz realidade da história com uma inimaginada força icônica".

${ }^{101}$ Amigoni, F. Fantasmi nel Novecento. cit., pp. 132-133: "Procurado, desejado, alucinado, o pai ausente é uma figura central da escritura de Tabucchi, que se pode encontrar em muitos romances e contos (...). Acontece, de fato, Freud lembra em mais de um lugar, que o pai ausente se transforme, no melhor dos casos, em um Superego, quanto mais esquivo, tanto mais severo; enquanto que, no pior dos casos, fecha, para o sujeito, todas as entradas ao simbólico".

${ }^{102}$ Amigoni, F. Fantasmi nel Novecento. cit., p. 133: "perda da distinção entre linguagem e referente” e p. 139: "a inviolabilidade das fronteiras que separam vivos e mortos".

${ }^{103}$ Ceserani, R. Il Fantastico. Bolonha: Il Mulino, 1996. pp. 141-142.
} 
entre os dois mundos é o telefone, a perturbante mensagem telefônica que faz o narrador entrar em ação e tentar encontrar a mulher de seu passado. Já em "I pomeriggi del sabato", o objeto mediador, que o fantasma de bicicleta parece reclamar é o seu “chapéu”, com o qual seria possível se reparar do sol e tirar o lenço amarrado na cabeça. Quando a mãe vai ao encontro dele, "in una mano, con delicatezza, come se portasse un oggetto prezioso, teneva un cappello da uomo" ${ }^{104}$, objeto que o menino reconhece imediatamente. E é justamente o misterioso desaparecimento deste, ao retorno da mãe, que parece confirmar o encontro desta com o fantasma. $\mathrm{O}$ protagonista, entretanto, permanece à distância, observando a cena através das persianas.

\footnotetext{
${ }^{104}$ Tabucchi, A. "I pomeriggi del sabato". cit., p. 68: "na mão, com delicadeza, como se levasse um objeto precioso, segurava um chapéu de homem".
} 


\subsection{IL NESSO FRA LE COSE: OS SUBTEXTOS NARRATIVOS}

“... la letteratura è una realtà parallela”.

Antonio Tabucchi.

A presença de textos literários como subtexto narrativo é outro procedimento estrutural do conto "Il gatto dello Cheshire" que nos interessa analisar. A referência à Alice no país das maravilhas, presente no conto desde o seu título, não só alude aos personagens de Lewis Carrol, como ajuda a construir a personalidade dos personagens tabucchianos. Aliás, as únicas referências à subjetividade destes personagens são dadas através da obra de Carrol: tanto a mulher identificada pelo apelido "Alice" como o narrador são compostos a partir das características dos personagens de Carrol, o modo de ser destes personagens aos quais se alude preenche o "vazio" de subjetividade dos personagens do conto. O narrador, por exemplo, é descrito como aquele que "sfuggisce e ci lascia il sorriso malizioso di furberia di chi prende in giro la vita"105. O texto de referência é, deste modo, responsável por preencher os vazios, as fissuras, os "buracos" da narrativa, estabelecendo "un nesso fra le cose" - um nexo entre as coisas.

Este procedimento narrativo é utilizado em outros contos de Il gioco del rovescio, em que a criação do personagem não está circunscrita à narrativa, mas ultrapassa os limites do texto literário, evocando personagens reais ou fictícios pré-existentes, como, por exemplo, Dolores Ibarruri no conto "Dolores Ibarruri versa lacrime amare" e Dino Campana, em "Vagabondaggio"; ou os personagens fitzgeraldianos presentes no conto "Il Piccolo Gastby":

"Il livello fictional di questi personaggi, che hanno subito un'immaginaria reincorporazione di dialogare nel reale, raggiunge così la seconda potenza. L'idea di dialogare con propri od altrui personaggi ha naturalmente origine in Pirandello e Pessoa; intertesto consustanziale ad Antonio Tabucchi”"106.

\footnotetext{
${ }^{105}$ Tabucchi, A. "Il gatto dello Cheshire". cit., p. 372: "foge e nos deixa o sorriso malicioso de esperteza de quem zomba da vida".

${ }^{106}$ Palmieri, G. "Per una volatile leggerezza: il 'lato manco' di Antonio Tabucchi”. In: Piccole finzioni con importanza. cit., p. 126: "O nível ficcional destes personagens, que sofreram uma imaginária
} 
Estes personagens que transitam entre o real e o ficcional são marcados pela ausência, pela incompletude de sua caracterização, não apresentam uma personalidade precisa, são fragmentários e/ou "vazios" "107, e a única possibilidade de preencher este vazio é dado ao leitor através do nome, que retoma um texto da realidade. Ocorre, assim, uma incorporação textual desses personagens extratextuais como elemento estrutural e constitutivo da ficção.

Em "Il Piccolo Gatsby", por exemplo, Tabucchi utiliza não só os textos de Fitzgerald para caracterizar seus personagens, como também cria um jogo com o título do romance The Great Gatsby. "Piccolo", neste sentido, pode ser referência à forma breve, o conto, menor que o romance. O protagonista deste conto é um escritor que se encontra preso entre duas possibilidades: a identificação total com a ficção de Fitzgerald e o desejo de escrever um livro totalmente seu.

Os personagens do conto, como se fossem atores, "representam os papéis" dos personagens de Tender is the night e de The Great Gatsby, assumindo a máscara destes e interpretando-as até o fim, marcando um jogo intertextual, assinalado pelo autor já na nota que precede a narrativa:

"Per una più immediata lettura del racconto Il Piccolo Gatsby è forse opportuno ricordare che Tom Barban, Nicole, Dick, Rosemary Hoyt, Abe North, Brady e i signori McKisco sono personaggi di Tender is the night di Fitzgerald, e Daisy un personaggio di The Great Gatsby",108.

O mesmo procedimento de "representação de papéis" ocorre com os personagens de "Teatro", um jovem português que vai trabalhar em Moçambique e encontra ali um velho ator inglês exilado. A amizade e o diálogo que se estabelecem entre os dois são marcados pela encenação de papéis e por citações de frases e trechos do Rei Lear de Shakeaspeare, recriados pelo narrador através do uso do discurso indireto livre.

reincorporação de dialogar no real, alcança assim a segunda potência. A ideia de dialogar com os personagens, próprios ou de outros, tem origem, naturalmente, em Pirandello e Pessoa; intertexto consubstancial a Antonio Tabucchi”.

${ }^{107}$ Génard, Pierre. "Rue des boutiques oscures/Il filo dell'orizonte: Vacanza del personaggio, vacanza del senso". In: I 'Notturni' di Antonio Tabucchi. cit., pp. 219-220.

${ }^{108}$ Tabucchi, A. "Il piccolo Gatsby". In: Racconti. cit., p. 71: "Para uma leitura mais imediata do conto Il piccolo Gatsby é oportuno, talvez, recordar que Tom Barban, Nicole, Dick, Rosemary Hoyt, Abe North, Brady e o casal McKisco são personagens de Tender is the night de Fitzgerald, e Daisy, um personagem de The Great Gatsby". 
O início do conto "Il piccolo Gatsby", por sua vez, consiste na citação de um trecho inicial do romance fitzgeraldiano, que depois se revela uma zombaria do narrador-protagonista que, enquanto tenta escrever um conto, escreve também para a mulher que teria abandonado, retomando lembranças da vida em conjunto e leituras da obra de Fitzgerald que fizeram juntos:

"Le sere erano lente, indugiate, insanguinate da tramonti magnifici. Seguivano notti calde e languide, punteggiate dal singhiozzo verde del faro, dall'altra parte del golfo. Ti piacerebbe che il mio racconto cominciasse così, vero?"109.

O conto mistura realidade e ficção num jogo de encenação de papéis que era característico da relação do protagonista com a mulher e os amigos do casal. O problema da identidade é posto aqui em chave intertextual ${ }^{110}$.

O narrador conhecia de cor o início dos romances de Fitzgerald, e frequentemente os recitava nos encontros festivos com os amigos, na mansão do casal. Bastava esta citação para dar início ao jogo: cada personagem do conto assumia o papel de um personagem de um romance fitzgeraldiano e o representava por toda a noite, enquanto o narrador se sentia, com o passar do tempo, cansado e pouco à vontade com os jogos superficiais e frívolos ali interpretados:

"Io sapevo solo a memoria inizi di romanzi altrui, appartenevo a una storia affine, ero un personaggio trasmigato da un altro romanzo, la sua stilizzazione in una dimensione minore, senza grandezze e senza tragedie" ${ }^{\prime 11}$.

O jogo literário toma conta da vida dos personagens e, enquanto tenta escrever seu romance, o narrador vai refletindo sobre a frivolidade da vida que leva, sente-se vivendo um "jogo dentro do jogo": "Io ero un gioco nel nostro gioco: ero il tuo caro piccolo

\footnotetext{
${ }^{109}$ Tabucchi, A. "Il piccolo Gatsby". cit., p. 73: "As tardes eram lentas, demoradas, com magníficos pores do sol avermelhados. Seguiam noites quentes e lânguidas, acentuadas pelo soluço verde do farol, do outro lado do golfo. Você gostaria que o meu conto começasse assim, não?”.

${ }^{110}$ Jansen, M. "Tabucchi: molteplicità e rovescio". In: Piccole finzioni con importanza. cit., p.138.

${ }^{111}$ Tabucchi, A. "Il piccolo Gatsby”. cit., p. 77: "Eu só sabia de cor o início de romances alheios, pertencia a uma história parecida, era um personagem migrado de outro romance, a sua estilização em uma dimensão menor, sem grandezas e sem tragédias".
} 
Gastby" "112. Até que abandona a encenação, consciente da "inadeguatezza" de sua vida, abandonando a casa e a mulher.

Esta encenação de papéis também ocorre em "Dolores Ibarruri versa lacrime amare". Desta vez, entretanto, a atmosfera frívola e superficial dos romances fitzgeraldianos cede espaço à narração desesperada de uma mãe que chora a perda do filho, morto pela polícia após ter cometido "atos atrozes". A mãe é entrevistada por um jornalista e tenta reverter ("rovesciare") a imagem de terrorista do filho contando-lhe sobre a infância alegre, os jogos que fazia junto do pai, resgatando a afetividade e a inteligência que contrastam com a imagem criada pelos jornais.

Ao contar sobre a vida do filho, a mãe também resgata a história do marido, um partigiano que tinha participado das brigadas internacionais e combatido na Guerra da Espanha, onde teria conhecido personalidades importantes, dentre elas, Dolores Ibarruri. A mãe recorda a admiração do filho pelos ideais do pai, além da amizade dos dois que se enriquecia com as leituras e os jogos literários que faziam:

\footnotetext{
"Facevano un gioco, era un gioco bellissimo, voglio dire credo che fosse una cosa molto poetica, leggevano dei libri e poi si scrivevano delle lettere come se ciascuno di loro fosse un personaggio dei libri che avevano letto, personaggi di fantasia o personaggi storici" ${ }^{\prime 13}$.
}

O título do conto faz referência a uma destas cartas que o filho teria escrito ao pai, quando este, doente, nos seus últimos dias de vida, lia nos jornais as notícias sobre a Rússia, sobre as atrocidades cometidas durante o stalinismo para a manutenção do regime comunista, e se angustiava com o que sucedia ali e no mundo:

\footnotetext{
"Rodolfo ... passò gli ultimi giorni molto agitato, ma non per la malattia, era angosciato per quello che stava succedendo nel mondo, cioè in Russia, non saprei esattamente, so che Kruscev aveva rivelato le atrocità commesse dai suoi predecessori, e lui si tormentava, non dormiva più, anche i sonniferi non gli facevano effetto, poi un giorno arrivò una lettera per lui, il mittente
}

\footnotetext{
${ }^{112}$ Tabucchi, A. "Il piccolo Gatsby". cit., p. 77: "Eu era um jogo dentro do nosso jogo, era o seu querido pequeno Gatsby".

${ }^{113}$ Tabucchi, A. "Dolores Ibarruri versa lacrime amare". In. Racconti. cit., p. 91: "Faziam um jogo, era um jogo belíssimo, quer dizer, acho que era uma coisa muito poética, liam livros e depois se escreviam cartas como se cada um deles fosse um personagem dos livros que tinham lido, personagem de fantasia ou personagem histórico".
} 
diceva: La Passionaria, Mosca. E dentro c'era scritto: Dolores Ibarruri versa lacrime amare.

Ecco, così era mio figlio" $" 114$.

Ao recontar a história da perda sofrida, a mãe entrelaça o destino de pai e filho, narrando como o heroísmo e os ideais políticos do pai teriam influenciado a vida do filho, que acaba por se aliar a grupos radicais e a cometer atos terroristas, considerados “atrozes" pelos jornais. A narração da mãe revela, entretanto, a doçura e o afeto do filho, que contrastam com as "atrocidades" noticiadas pelos jornais. Os atos terríveis e assustadores cometidos pelo filho e pelos "heróis" do pai apontam, todavia, para o caráter emblemático da história que, com sua natureza ambígua, imprevisível e devastadora, é representada por Tabucchi, não só neste como em muitos outros contos, como uma figura "bizarra", irresponsável, que não sofre o peso da culpa: "Ah, la Storia, che dama bizzarra! Mi ha detto che non ha nessuna responsabilità, lei non ha colpa di niente" $" 115$.

Esta concepção tabucchiana da história retoma, entre outras leituras, o poema de Eugenio Montale, La Storia, em que o poeta critica a interpretação da história como uma simples sucessão de acontecimentos, além de questionar o fato de que a história ensina $^{116}$. No conto tabucchiano, a história da vida do filho repete a do pai, mas sem nenhuma possibilidade de superação ou aprendizagem: as perdas, os desastres e os sofrimentos, apesar da mudança dos tempos e dos ideais, continuam a afligir a humanidade, prescindindo, todavia, de uma função transformadora e liberadora.

A imagem de Dolores Ibarruri que derrama lágrimas amargas é retomada por Tabucchi alguns anos depois, no fragmento de "Passato composto. Tre lettere", de $I$ volatili del Beato Angelico. Neste, o autor repete o jogo descrito no conto de $\mathrm{Il}$ gioco del rovescio escrevendo cartas em nome de personagens históricos ou literários para outros personagens, desta vez, personagens separados não só espacialmente como também por

\footnotetext{
${ }^{114}$ Tabucchi, A. "Dolores Ibarruri versa lacrime amare". cit., p. 91: "Rodolfo ... passou os últimos dias muito agitado, mas não pela doença, estava angustiado por aquilo que acontecia no mundo, isto é, na Rússia, não saberia exatamente, sei que Khrushchov tinha revelado as atrocidades cometidas pelos seus antecessores, e ele se atormentava, não dormia mais, nem os soníferos faziam efeito, depois um dia chegou uma carta para ele, o remetente dizia: A Pasionaria, Moscou. E dentro estava escrito: Dolores Ibarruri derrama lágrimas amargas. Pois bem, meu filho era assim".

${ }^{115}$ Tabucchi, A. Racconti con figure. Palermo: Sellerio Editore, 2011. p. 70: "Ah, a História, que dama bizarra! Disse-me que não tem nenhuma responsabilidade, ela não tem culpa de nada".

${ }^{116}$ Montale, E. Poesias. Trad. Geraldo Holanda Cavalcanti. Rio de Janeiro/São Paulo: Ed. Record, 1997. "La storia non è magistra di niente che ci riguardi. Accorgersene non serve a farla più vera e più giusta".
} 
uma distância temporal: Dom Sebastião de Aviz escreve a Goya, Mademoseille Lenormand escreve a Dolores Ibarruri e Calipso a Odisseu.

Este jogo da encenação dos papéis como procedimento narrativo resgata uma temática pirandelliana, ao mesmo tempo em que, como considera Trentini, torna o escritor "herdeiro" das suas teorias inovadoras sobre o romance e a ficção, acrescente-se também, sobre o personagem, aceitando prosseguir o caminho de quem o precedeu, mas com a consciência de fim de século de que o "personaggio esiste al di là della storia, al di là delle circostanze e al di là della vita"117.

Esse processo de estruturação da subjetividade do personagem pela mediação de obras literárias, ou de "fícção dentro da ficção", retoma não só Pirandello, como também Fernando Pessoa e o seu processo de heteronímia. De fato, os personagens tabucchianos são construídos a partir de uma "identidade fictícia" combinada com o gosto pelo "scambio dei ruoli" 118 - sobretudo entre narrador e personagem, se pensarmos, por exemplo, no jogo do revés encenado pelo narrador e Maria do Carmo, em "Il gioco del rovescio":

\begin{abstract}
"Senti, chissà cosa siamo, chissà dove siamo, chissà perché ci siamo, senti, viviamo questa vita come se fosse un revés, per esempio stanotte, tu devi pensare che sei me e che stai stringendo te fra le tue braccia, io penso di essere te che sto stringendo me fra le mie braccia" ${ }^{\prime 19}$.
\end{abstract}

De acordo com Anna Dolfi, Tabucchi parece ter a necessidade de recorrer a "imagens alteradas de uma identidade", utilizando-as como "pontos de vista deslocados" para apreender uma realidade fugidia. Identidade esta que busca não só em histórias e personagens literários precedentes, como também na arte figurativa - basta pensar no quadro de Velázquez, que aparece em "Il gioco del rovescio" como parte constituinte da personalidade de Maria do Carmo; no quadro As tentações de Santo Antão de Bosch, citado em alguns contos de L'Angelo Nero e em Requiem, e no Beato

\footnotetext{
${ }^{117}$ Trecho de Tabucchi citado por Trentini, N. In: Una scrittura in partita doppia. cit., p. 222: "o personagem existe além da história, além das circunstâncias, além da vida".

${ }^{118}$ Dolfi, A. Gli oggetti e il tempo della saudade. cit., p. 11: "troca dos papéis".

${ }^{119}$ Tabucchi, A. "Il gioco del rovescio". In: Racconti. cit., p. 18: "Escuta, quem sabe o que somos, quem sabe onde estamos, quem sabe porquê estamos aqui, escuta, vamos viver esta vida como se fosse um revés, por exemplo, esta noite, você deve pensar que sou eu e que estou te apertando nos meus braços, eu penso que sou você, que está me apertando nos seus braços".
} 
Angelico, que é personagem do conto que dá título à coletânea I volatili del Beato Angelico, - em cartas e documentos antigos que podem servir na reconstrução do passado - procedimento utilizado, por exemplo, em "Gli archivi di Macao, também da coletânea I volatili del Beato Angelico. São personagens que nascem, portanto, a partir de processos de "fabulação dialógica" ou que são retirados do silêncio dos quadros dos museus, fazendo com que os lugares do imaginário e os lugares literários correspondam uns aos outros, assim como verdade e ficção ${ }^{120}$.

Em "Il Piccolo Gatsby" e "Dolores Ibarruri versa lacrime amare", como podemos notar, personagens fictícios interagem com personagens "reais" recriados pelo autor. São personagens que possuem uma existência "de segundo grau”, já que o escritor os constrói a partir de uma vida "primeira" que eles possuíam no "texto" original. Assim, Dolores Ibarruri, no momento em que é inserida na ficção tabucchiana traz, junto com seu nome, suas referências pessoais, sua vida, seu tempo e seu espaço, pois em cada nome "c'è il tempo passato insieme, le persone che ci sono morte, cose fatte insieme, luoghi, altri nomi, la nostra vita",121.

Tabucchi trabalha, nestes contos, com um procedimento de intertextualidade característico da ficção contemporânea e pós-moderna, na medida em que procura formas de incorporar o passado no texto do presente, e o faz por meio do jogo literário, da reelaboração crítica de suas narrativas. Este processo, todavia, não se dá de maneira ingênua, e por isso o autor utiliza uma espécie de "paródia seriamente irônica" que permite uma duplicidade contraditória: os intertextos da história assumem um status paralelo na reelaboração paródica do passado textual do 'mundo' e da literatura. A paródia recupera a história e a memória, incorporando textualmente esses passados intertextuais como elemento estrutural e constitutivo da ficção. Esta intertextualidade funciona, portanto, como uma manifestação formal de um desejo de reduzir a distância entre o passado e o presente do leitor e também de reescrever o passado dentro de um novo contexto ${ }^{122}$.

Assim, a ficção tabucchiana faz com que passado e presente sejam diretamente confrontados por meio da ironia, de modo que o repensar irônico da história não seja nostálgico, mas sim um confronto crítico do passado com o presente. De acordo com

\footnotetext{
${ }^{120}$ Dolfi, A. Gli oggetti e il tempo della saudade. cit., pp. 12-14.

${ }^{121}$ Tabucchi, A. "Dolores Ibarruri versa lacrime amare". In: Racconti. cit., p. 87: "tem o tempo passado junto, os nossos mortos, as coisas feitas juntos, lugares, outros nomes, a nossa vida".

${ }^{122}$ Hutcheon, L. Poética do Pós-Modernismo. cit., p. 64 e ss.
} 
Umberto Eco, o jogo da ironia está intrinsecamente envolvido na seriedade do objetivo e do tema, sendo a ironia a única forma de ser "sério nos dias de hoje" $" 123$. Na literatura contemporânea, os discursos que precedem e contextualizam tudo aquilo que se diz e se faz não podem ser deixados de lado, e é por meio da paródia irônica que o autor de hoje indica sua percepção sobre este fato inevitável. Aquilo que "já foi dito" precisa ser reconsiderado, e só pode ser reconsiderado de forma irônica ${ }^{124}$.

\footnotetext{
${ }^{123}$ Eco, Umberto. Pós-escrito a O nome da rosa. Trad. Letizia Zini Antunes e Álvaro Lorencini. Rio de Janeiro: Nova Fronteira, 1985.

${ }^{124}$ Hutcheon, L. Poética do Pós-Modernismo. cit., p. 64.
} 


\section{PICCOLI EQUIVOCI E O ENIGMA DO REAL}

\subsection{O UNIVERSO LITERÁRIO COMO ENIGMA E/OU EQUÍVOCO.}

"O real não é o objeto da representação, mas o espaço em que se dá um mundo fantástico."

Ricardo Piglia.

Em Piccoli equivoci senza importanza, coletânea de contos de 1985, temos um jogo entre engano e desengano que, já no prefácio, é tematizado pelo próprio autor a propósito da ideia de equívoco no Barroco. Diz Tabucchi que os barrocos elevaram o equívoco a estatuto de metáfora do mundo e que, embora este seja também o tema de seu livro, os mal-entendidos, as incertezas, os lamentos inúteis, as recordações enganosas, os erros irremediáveis, são sempre coisas fora de lugar que exercem certa atração irresistível, mas que não passam de um conjunto de "pobres estimativas desprovidas de sublime":

"le cose fuori luogo esercitano su di me un'attrazione irresistibile, quase fosse una vocazione, una sorta di povera stimmate priva di sublime. Sapere che si tratta di un'attrazione ricambiata non è esattamente una consolazione. Mi potrebbe consolare la convinzione che l'esistenza sia equivoca di per sé e che elargisca equivoci a tutti noi",125.

O universo literário visto como equívoco e/ou enigma é, de acordo com Nives Trentini, um desdobramento da ideia de "rovescio", "è una delle tante declinazioni del

\footnotetext{
${ }^{125}$ Tabucchi, A. Prefazione a Piccoli equivoci senza importanza. In: Racconti. cit., p. 125: "as coisas fora de lugar exercem sobre mim uma atração irresistível, quase como se fosse uma vocação, uma espécie de pobre estigma desprovido de sublime. Saber que se trata de uma atração recíproca não é exatamente um consolo. Poderia me consolar a convicção que a existência seja equívoca em si e que distribua equívocos a todos nós".
} 
'gioco' della vita, con i suoi paradossi, a cui tutti siamo chiamati a rispondere" ${ }^{126}$; um efeito do incongruente, uma sucessão de perguntas sem respostas, resultado de escolhas paradoxais que aprisionam os personagens. Nesse livro, o azar, o equívoco, o aleatório intervém construindo uma rede de relações, na qual se agrava e se atenua de modo ambíguo e incerto a responsabilidade dos personagens que enfrentam situações em que foram envolvidos de modo inesperado. As experiências são regidas pela articulação entre a contingência e o erro. As certezas se dissipam por meio de um sofisticado jogo de contrários que revela o avesso das coisas. Ao propor tramas abertas e/ou finais imprevisíveis para suas narrativas, além da reflexão sobre o próprio processo de escrita, Tabucchi propõe uma "ontologia da dúvida" como temática, um espaço narrativo em que predomina a incerteza e a negação ${ }^{127}$.

No conto que dá título a coletânea, "Piccoli equivoci senza importanza", por exemplo, um grupo de amigos separados pelos acontecimentos da vida, reencontra-se, por ironia do destino, no julgamento de um deles. O narrador, Tonino, um jornalista, deve noticiar o julgamento, no qual dois de seus amigos dos tempos de escola e universidade ocupam posições opostas no tribunal: um é o réu e o outro o juiz. Enquanto assiste ao julgamento e tenta entender os eventos do presente, o narrador vai recordando os anos da universidade, relembrando a amizade dos jovens separados pelos acasos da vida.

Nesse conto, como em outros de Tabucchi, podemos perceber a manipulação dos dados históricos por parte do autor. As lembranças do narrador retomam o começo dos anos de 1970, anos de intensas manifestações culturais e políticas, protestos estudantis, transformações sociais e comportamentais. A narrativa alude a eventos reais ocorridos nestes anos na Itália, e também a atos terroristas que marcaram os Anos de Chumbo italianos. O narrador menciona vagamente um processo por terrorismo, atribuindo o ato ao personagem Leo, ex-colega universitário, que teria assumido, com o passar dos anos, um papel importante como militante de uma organização política de esquerda.

Como no conto "Il gioco del rovescio", a narrativa possui a mesma alternância entre passado e presente, deslizando do presente narrado, o julgamento, para o passado dos jovens amigos, na escola e depois na universidade, quando Leo, o réu, e Federico, o juiz, eram apenas rivais no amor de Maddalena. As marcas dos deslizamentos temporais

\footnotetext{
${ }^{126}$ Trentini, N. Una scrittura in partita doppia. cit., pp. 52-3: “é uma das tantas declinações do ‘jogo’ da vida, com os seus paradoxos, aos quais todos somos chamados a responder".

${ }^{127}$ Dolfi, A. Gli oggetti e il tempo della saudade. cit., p. 60.
} 
são assinaladas, no texto, por vozes fantasmáticas, longínquas e metálicas, tais como a de Federico, quando este telefona ao narrador Tonino, para saber da cirurgia que Maddalena deveria fazer. Ou ainda pela voz de Domenico Modugno, cantando Strada anfosa:

\begin{abstract}
"Quando l'usciere ha detto: in piedi, entra la corte, e nell'aula per un attimo si è fatto silenzio, proprio in quel momento, quando Federico è sbucato dalla porticina guidando il piccolo corteo, con la toga e i capelli già quasi bianchi, mi è venuta in mente Strada anfosa"128.
\end{abstract}

A música de Modugno, uma fonte intertextual do conto, é uma canção nostálgica que fala de dois amantes que se separam e seguem caminhos diferentes. No texto, é o elemento que ressurge na memória do narrador e que traz, para a narrativa do presente, a imagem de uma experiência pessoal pertencente ao passado. A lembrança dos tempos em que se reuniam na casa da avó de Leo, e os dois, Leo e Federico, apaixonados, disputavam Maddalena para uma dança, ao som da canção de Modugno. As recordações da juventude, aos poucos, impregnam o presente do narrador, fazendo com que ele não consiga entender o absurdo da situação a que assiste:

\begin{abstract}
"Li ho guardati sedersi, come assistendo a un rituale incomprensibile e lontano ma proiettato nel futuro, e l'immagine di quegli uomini gravi seduti dietro al bancone sovrastato da un crocefisso si è dissolta sotto l'immagine di un passato che era per me il presente, proprio come in un vecchio film...." ${ }^{129}$.
\end{abstract}

A canção não só evoca os tempos vividos como faz pensar no destino - o caminho que cada um seguiu na vida, além de funcionar como subtexto narrativo. Não é, todavia, a única fonte intertextual presente no conto: existe uma menção direta ao teatro de Sófocles, à peça Antígona, encenada pelos amigos na conclusão do curso de grego no último ano escolar. Simbolicamente, porém, a peça continua a "agir" na vida

\footnotetext{
${ }^{128}$ Tabucchi, A. "Piccoli equivoci senza importanza". In: Racconti. cit., p. 129: "Quando o oficial disse: em pé, entra a corte, e no recinto, por um instante, fez-se silêncio, justamente naquele momento, quando Federico saiu pela porta guiando o pequeno cortejo, com a toga e os cabelos já quase brancos, veio-me em mente Strada anfosa".

${ }^{129}$ Tabucchi, A. "Piccoli equivoci senza importanza". cit., p. 129: "Vi-os se sentar, como se assistisse a um ritual incompreensível e distante, mas projetado no futuro, e a imagem daqueles homens severos, sentados atrás da bancada, encimada por um crucifixo, dissolveu-se sob a imagem de um passado que, para mim, era presente, exatamente como em um velho filme...”.
} 
dos personagens, pois o julgamento do presente faz ecoar o processo de Creonte encenado anos atrás. Os papéis assumidos na representação teatral se tornam parte da vida real de cada um, como se as "máscaras gregas" utilizadas durante a representação se fixassem nos personagens, fazendo-os representar o seu papel em um espetáculo contínuo. Na encenação escolar, Maddalena interpretava Antígona e, após o espetáculo, todos passaram a chamá-la de "A Grande Trágica". Leo interpretava o papel do irmão morto e insepulto, enquanto Federico era Creonte. Ao narrador Tonino, coube a parte do coro, ou seja, era aquele que comentava os eventos representados, e de fato, o narrador personagem continua observador "estático" das cenas que se desenvolvem.

Os jovens são obrigados a representar seus papéis não só no espetáculo, mas também na vida, e nesta, como na tragédia grega, domina o Destino (Moros), deus da sorte e do acaso, filho do Caos e da Noite. Representado por uma entidade cega, o deus da fatalidade não vê aquele a quem distribui o seu futuro, o seu caráter é o da inevitabilidade, e todos, deuses e mortais, estão subordinados a ele.

É justamente o destino a criar, na vida de Federico ainda estudante, um "pequeno equívoco" que o transformará em outro Federico:

\begin{abstract}
“A un certo punto arrivò Federico con un'aria stravolta sventolando il suo libretto di matricola, era trafelato e quasi non riusciva a spiegarsi, era fuori di sé, per errore gli avevano dato un libretto di Giurisprudenza, non sapeva capacitarsene. Per confortarlo lo accompagnammo alle segreterie, ci attese un impiegato gentile e noncurante, era un vecchietto che aveva visto sfilare davanti a sé migliaia di studenti, esaminò il libretto di Federico e la sua aria preoccupata: è un piccolo equivoco senza rimedio, disse, è inutile preoccuparsi tanto" 130 .
\end{abstract}

Federico queria se inscrever no curso de Letras Clássicas, enquanto os amigos tinham ingressado no curso de Letras Modernas, mas devido a este engano, começa a frequentar as aulas de Filosofia do Direito e percebe que os trágicos gregos não podiam lhe explicar certos problemas do mundo que ele não conseguia entender bem. Por este motivo, decide permanecer no curso de Direito, tornando-se, anos depois, um juiz.

\footnotetext{
${ }^{130}$ Tabucchi, A. "Piccoli equivoci senza importanza". cit., p. 130: "De repente chegou Federico com ar de desespero, agitando o seu manual do ingressante, estava ofegante e quase não conseguia se explicar, estava fora de si, tinham lhe dado um manual do Direito, não conseguia entender o motivo. Para confortálo, acompanhamo-lo à secretaria, um empregado gentil e negligente nos recebeu, era um velhinho que tinha visto milhares de estudantes desfilarem diante de si, examinou o manual de Federico e o seu ar preocupado: é um pequeno equívoco sem remédio, disse, é inútil se preocupar muito”.
} 
A frase do empregado da secretaria que determina a vida do jovem consistia, na verdade, em um "lapso" do velhinho, que pretendia dizer "pequeno equívoco sem importância". Este "lapso" é transformado, pelos jovens, em um refrão "emblemático", pois, a partir de então, as mais diversas circunstâncias, os enganos, os mal-entendidos, os descuidos, tornavam-se "pequenos equívocos sem importância”, já que a frase servia como uma desculpa lúdica que se encaixava bem em qualquer contexto.

Este "pequeno equívoco" dá origem, porém, a outro Federico: ao juiz que permanece impassível diante das perguntas do Ministério Público e das respostas de Leo. O narrador, refletindo sobre a inevitabilidade do destino, tenta se consolar pensando, por um instante, que tudo não passava de uma encenação, mas depois se dá conta que era tudo real:

\footnotetext{
"ma non era una recitazione, no, era una cosa vera, stavano davvero processando il Leo, e anche le cose che il Leo aveva fatto erano vere, e lui le stava confessando candidamente, impassibile, e Federico lo ascoltava impassibile, e allora ho pensato che anche lui non poteva fare altrimenti, perché quella era la sua parte nella commedia che ci stavano giocando"131.
}

O narrador percebe, então, que às vezes o "papel" ou a "máscara" que uma pessoa é obrigada a assumir em determinada situação, pode se tornar a sua realidade, fazendo com que este assuma não só a identidade da máscara, como também a responsabilidade pelas ações a ela atribuída. Isso porque a vida, no seu fluir contínuo, enrijece e pode determinar que as coisas e as atitudes de um dado momento se tornem escolhas definitivas: "la vita è così brava a sclerotizzare le cose, e gli atteggiamenti diventano le scelte" ${ }^{, 132}$.

Tabucchi parece dialogar, neste conto, com o conceito de máscara e com a dialética "vida $\mathrm{x}$ forma", presentes na obra pirandelliana. $\mathrm{O}$ conceito de máscara ocupa papel central no teatro de Pirandello, basta lembrar o título geral que organiza sua dramaturgia: Maschere Nude. Além disso, o teatro de Pirandello postula a contradição

\footnotetext{
${ }^{131}$ Tabucchi, A. "Piccoli equivoci senza importanza". cit., p. 134: "mas não era uma encenação, não, era uma coisa séria, estavam processando o Leo de verdade, e também as coisas que o Leo tinha feito eram verdadeiras, e ele as estava confessando candidamente, impassível, e Federico o escutava impassível, então pensei que ele também não podia fazer diferente, porque aquele era o seu papel na comédia que estavam recitando".

${ }^{132}$ Tabucchi, A. "Piccoli equivoci senza importanza". cit., p. 133: "a vida é muito boa em enrijecer as coisas, e as atitudes se tornam as escolhas".
} 
entre a "forma fixa" que a máscara determina e o "fluxo vital" que corre incessantemente:

\begin{abstract}
"La vita è un flusso continuo che noi cerchiamo d'arrestare, di fissare in forme stabili e determinate, dentro e fuori di noi, perché noi già siamo forme fissate, forme che si muovono in mezzo ad altre immobili, e che però possono seguire il flusso della vita, fino a tanto che, irrigidendosi man mano, il movimento, già a poco a poco rallentato, non cessi. Le forme in cui cerchiamo d'arrestare, di fissare in noi questo flusso continuo, sono i concetti, sono gli ideali a cui vorremmo serbarci coerenti, tutte le finzioni che ci creiamo, le condizioni, lo stato in cui tendiamo a stabilirci" ${ }^{133}$.
\end{abstract}

$\mathrm{Na}$ literatura pirandelliana, a vida, como fluxo contínuo, opõe-se à necessidade social de estabelecer uma forma fixa para cada sujeito. $\mathrm{O}$ personagem pirandelliano não se conforma em usar uma máscara, não aceita ser forma fixada. A máscara é um reflexo de formas externas e leis sociais, a identidade que cada um assume. Por isto, ela aprisiona e fixa o personagem em um papel social determinado, do qual não se pode escapar. O personagem se torna, então, aquilo que os outros acreditam que ele seja, e sua identidade é construída de fora para dentro. É somente através do investimento no papel social que o eu consegue se auto-afirmar na sociedade; despojado de sua máscara, perde sua consistência, torna-se fantasma, sombra de si mesmo.

Analogamente, no conto de Tabucchi, a máscara utilizada pela encenação dos jovens estudantes no passado, determina a construção da identidade futura de cada personagem, que permanece aprisionado ao seu papel na comédia que haviam encenado:

"e anch'io che ero venuto con il mio blocchetto per gli appunti, anche il mio semplice guardare loro che recitavano la loro parte, anche questa era una

\footnotetext{
${ }^{133}$ Pirandello, L., L' umorismo. Org. Maria Argenziano. Roma: Newton, 1993. p. 93. Ed. Bras. $O$ Humorismo. Trad. J. Guinsburg. In:_ Do teatro no teatro. Org. J. Guinsburg. São Paulo: Perspectiva, 1999. p. 169: "A vida é um fluxo contínuo que nós procuramos deter, fixar em formas estáveis e determinadas, dentro e fora de nós, porque nós já somos formas fixadas, formas que se movem em meio a outras imóveis, e que por isso podem seguir o fluxo da vida, até que, enrijecendo-se sucessivamente, o movimento, já pouco a pouco relentado, não cessa. As formas, em que procuramos deter, fixar em nós esse fluxo contínuo, são os conceitos, são os ideais em relação aos quais queremos nos conservar coerentes, todas as ficções que nós criamos, as condições, o estado em que tendemos a estabelecer-nos".
} 
parte, e in questo consisteva la mia colpa, nello stare al gioco, perché non ci si sottrae a niente e si ha colpa di tutto, ognuno a modo suo" ${ }^{, 134}$.

Vê-se, neste trecho, que o narrador, assim como os personagens tabucchianos em geral, sente-se moralmente responsável pela realidade que escolheu, mesmo que esta realidade não faça nenhum sentido. Para estes personagens, a vida é prisioneira de suas representações, e nestas, a culpa - tema central da obra narrativa de Tabucchi, segundo muitos de seus críticos - está sempre presente: "perché non ci si sottrae a niente e si ha colpa di tutto" ${ }^{135}$. A culpa do narrador, neste caso, consiste na imobilidade, em estar no jogo e não poder se esquivar dele, em estar ali presente observando cada um que interpreta o seu papel. Conforme Anna Dolfi, nos contos tabucchianos, a culpa e o remorso estão sempre prontos a aflorar, enquanto a escrita, tenta racionalizá-los:

\footnotetext{
"La colpa è sempre là, sempre pronta a riemergere, legata a storie di guerra, a imprese partigiane, o al terrorismo degli anni di piombo: sonno della ragione, della volontà, del coraggio, che d'un tratto produce mostri, mentre la scrittura tenta di razionalizzarli cercando di contenere anche la colpa"136.
}

Enquanto assiste ao julgamento, o narrador retrocede e avança no tempo, vê passar os anos, como se o tempo fosse um "carrossel" que gira sem ordem, e assim relembra o fato de ter encontrado Maddalena antes de uma cirurgia, em que teve os seios amputados. Relembra também a conversa telefônica que teve neste dia com Federico, quando este estava fazendo os exames para procurador e não pôde estar ao lado dela. Recorda os anos de militância política do jovem e sarcástico Leo, os seminários aos quais participaram juntos, e também o fato que, devido a pequenos equívocos, Leo tornara-se o mais importante do grupo.

\footnotetext{
${ }^{134}$ Tabucchi, A. "Piccoli equivoci senza importanza". cit., p. 135: "e eu também, que viera com meu bloquinho de notas e até mesmo meu simples olhar voltado àqueles que encenavam seus papéis, também era um papel, e nisso consistia a minha culpa, em estar no jogo, porque não se escapa de nada e se tem culpa de tudo, cada um a seu modo".

${ }^{135}$ Tabucchi, A. "Piccoli equivoci senza importanza". cit., p. 135: "porque não se escapa de nada e se tem culpa de tudo, cada um a seu modo".

${ }^{136}$ Dolfi, A. Gli oggetti e il tempo della saudade. cit., p. 53: “A culpa está sempre lá, sempre pronta a aflorar, ligada a histórias de guerra, a empresas partigianas, ou ao terrorismo dos anos de chumbo: sono da razão, da vontade, da coragem, que de repente produz monstros, enquanto a escrita tenta racionalizálos buscando também conter a culpa".
} 
No tribunal, o processo continua e um comentário espirituoso de Leo e sua expressão maliciosa trazem para o narrador, assim como para Federico, um momento opressivo de grande tristeza. Diante deste sentimento, o narrador pensa em fazer ou dizer algo que pudesse romper a cadeia de atos desastrosos que os levaram até ali. Mas se dá conta que não se pode escapar desta "complicação" imposta pelo destino:

\begin{abstract}
"Ma cosa potevo dirgli, che si trattava di un piccolo equivoco senza rimedio? Perché mentre pensavo questo ho proprio pensato che tutto era davvero un enorme piccolo equivoco senza rimedio che la vita si stava portando via, ormai le parti erano assegnate e era impossibile non recitarle (...) E allora mi è venuta una grande stanchezza e una specie di vergogna, e insieme è arrivata un'idea che mi ha assalito e che non ho saputo decifrare, qualcosa che potrei chiamare il desiderio della Semplificazione. In un attimo, seguendo un gomitolo che si stava srotolando con la velocità di una vertigine, ho capito che noi eravamo lì a causa di una cosa che si chiama Complicazione, e che per secoli, per millenni, per milioni di anni essa ha condensato, strato su strato, circuiti sempre più complessi, sistemi sempre più complessi, fino a formare ciò che ora noi siamo e ciò che stiamo vivendo. E mi è venuta la nostalgia della Semplificazione, come se i milioni di anni che avevano prodotto gli esseri che si chiamavano Federico, il Leo, Maddalena, il Deputatino e io stesso - questi milioni di anni per sortilegio si dissolvessero in un bruscolo di tempo fatto di niente"
\end{abstract}

A partir desta reflexão, o narrador imagina todos sentados em uma folha, como se fossem seres microscópicos e mononuclerares "senza sesso, senza storia e senza ragione" 138 , mas ainda com um lampejo de consciência que permitia a todos de se reconhecer. Cabendo-lhes a simples e única função de estar ali, enquanto outra espécie tocava Strada anfosa para eles. Aqui o diálogo intertextual com a música de Modugno

\footnotetext{
${ }^{137}$ Tabucchi, A. "Piccoli equivoci senza importanza". cit., p. 135: "Mas o que poderia dizer-lhes, que se tratava de um pequeno equívoco sem remédio? Porque enquanto pensava nisso, pensei também que tudo era realmente um enorme pequeno equívoco sem remédio que a vida estava levando embora, agora os papéis estavam decididos e era impossível não representá-los (...) E então me veio um grande cansaço e uma espécie de vergonha, e junto me veio uma ideia que se apossou de mim e que eu não soube decifrar; algo que eu poderia chamar o desejo de Simplificação. Em um segundo, seguindo um novelo que estava se desenrolando com uma velocidade vertiginosa, entendi que estávamos ali devido a uma coisa que se chama Complicação, e que por séculos, por milênios, por milhões de anos ela condensou, camada sobre camada, circuitos sempre mais complexos, sistemas sempre mais complexos, até formar isto que agora somos e isto que estamos vivendo. E me veio a nostalgia da Simplificação, como se os milhões de anos que produziram os seres que se chamavam Federico, Leo, Maddalena, Deputadinho e eu mesmo - estes milhões de anos, por encanto, se dissolvessem em um cisco de tempo feito de nada".

${ }^{138}$ Tabucchi, A. "Piccoli equivoci senza importanza". cit., p. 135: "sem sexo, sem história e sem razão".
} 
se presentifica novamente, uma vez que a letra da canção alude ao fato de que o casal de amantes se conforma e aceita seu destino, separando-se e se resignando, assumindo e representando cada um seu papel.

Em meio a essas reflexões do narrador, a Corte e o público se levantam e Leo permanece sentado, fumando um cigarro. O narrador sai lentamente do tribunal, deixando em aberto o final do julgamento e o destino dos demais personagens. Lá fora, começa a caminhar pela rua que margeia o canal e imagina ver Leo e Federico, com suas expressões costumeiras, em um barco, enquanto Maddalena surge sorridente, ao fundo, com sua juventude e beleza esplêndidas. Percebe, neste momento, que os três possuíam uma "fissità immobile" - fixidez imóvel - e que sua visão não correspondia à imagem de pessoas, mas de manequins de gesso, semelhantes aos de uma vitrine. $\mathrm{O}$ narrador continua a caminhar tentando não pisar nos interstícios do piso, como fazia quando "ero bambino e con ingenuo rituale provavo a regolare sulla simmetria delle pietre la mia infantile decifrazione del mondo ancora senza scansione e senza misura" ${ }^{\prime 39}$.

O final do conto mostra que diante de uma realidade complexa, feita de mensagens difíceis de decifrar e na qual predomina a razão lógica - que, todavia, não explica as coisas, o narrador parece optar pela solução onírica e pelo desejo de retorno ao tempo da simplicidade da infância, à origem da humanidade, em uma espécie de evolução biológica ao contrário. Assim como em "Il gioco del rovescio", a narrativa termina com uma espécie de sonho. Solução comum à narrativa de Tabucchi que, frequentemente, postula a fuga ao universo do sonho e/ou da imaginação como alternativa para escapar das complicações que a vida impõe aos seus personagens. É neste universo onírico que a simplificação de todas as coisas e a participação em situações não concretizadas na vida podem ser possíveis, já que no sonho o tempo pode ser reversível.

O mecanismo do sonho permite a correção do tempo vivido. Neste universo é possível misturar e sobrepor passado e presente, transpor distâncias impensáveis em segundos, combinar personagens e lugares. É, portanto, o espaço e o momento em que o tempo tem seu início, em que a experiência noturna, paralela à da vida diurna pode se

\footnotetext{
${ }^{139}$ Tabucchi, A. "Piccoli equivoci senza importanza". cit., p. 136: "era criança e com um ritual ingênuo, tentava ajustar na simetria das pedras, a minha decifração infantil do mundo, ainda sem interpretação e sem medida".
} 
tornar "creatrice di un mondo dell'immaginario in cui i confini perdono consistenza per dar spazio ad una vita (narrativamente) concreta come quella vissuta quotidianamente" ${ }^{, 140}$.

Como o final do conto permanece em aberto, o leitor não consegue precisar o que acontece com os personagens, se Leo será condenado ou não. Ao adotar como procedimento narrativo a suspensão do final e a estrutura do sonho, Tabucchi se aproxima da literatura borgiana que, como nota Ricardo Piglia, é repleta de narrativas em que a ideia de um final aberto se mostra como um sonho. Diz Piglia que

\footnotetext{
"uma história pode ser contada de maneiras distintas, mas sempre há um duplo movimento, algo incompreensível que acontece e está oculto. O sentido de um relato tem a estrutura do segredo (...), está escondido, separado do conjunto da história, reservado para o final e em outra parte. Não é um enigma, é uma figura que se oculta”,141.
}

Em Tabucchi, como também em Borges, todavia, o sentido está aparentemente suspenso, o enigma ou a figura que se oculta não se revelam no final. $\mathrm{O}$ entendimento e a conclusão da história são subtraídos e/ou projetados para além do fim da narrativa. Piglia nota que, no conto "Sete noites", por exemplo, Borges narra, em um sonho, a subtração da "imagem secreta", da "figura oculta" que irrompe no final como revelação e possibilita o entendimento da narrativa. É uma narrativa sobre o encontro aparente de dois amigos, em que um sente como o outro parece mudado e triste, tomado pela enfermidade ou pela culpa. Até que se revele o que se escondeu, a história é apenas o relato de um encontro melancólico e trivial, mas depois, com um gesto, tudo se acelera e se torna nítido: o estranho do sonho narrado é o fato de o homem ter, desde o princípio, a mão escondida e, lentamente, enquanto vai tirando a mão para fora, deixa entrever que esta mão é, na verdade, a garra de um pássaro. Esta percepção só se dá, entretanto, perto do final, e o argumento da narrativa

\footnotetext{
${ }^{140}$ Trentini, N. Una scrittura in partita doppia. cit., p. 251: "criadora de um mundo do imaginário em que as fronteiras perdem consistência para dar espaço a uma vida (narrativamente) concreta como aquela vivida quotidianamente".

${ }^{141}$ Piglia, R. Formas breves. Trad. José M. M. de Macedo. São Paulo: Companhia das Letras, 2004. p. 106.
} 
“dá um giro e encontra sua forma, o relato está nessa mão oculta. A forma se condensa numa imagem que prefigura a história completa. Há algo no final que estava na origem, e a arte de narrar consiste em postergá-lo, mantê-lo em segredo, até revelá-lo quando ninguém o espera" ${ }^{142}$.

À maneira de Borges, a narrativa de Tabucchi procura meditar sobre a "amplitude da experiência", rompendo com o caráter fechado da forma, delegando a compreensão e o sentido para um além-texto ou revelando o oculto nos interstícios da própria narrativa. É também uma "arte da duplicação", capaz de "pressentir o inesperado" e que sabe "esperar o que vem, nítido, invisível”, pois, conforme Piglia, a "literatura permite pensar o que existe, mas também o que se anuncia e ainda não é"143.

Neste sentido, a presença do sonho e da imaginação são indispensáveis para preencher os "vuoti lasciati scoperti dall'abolizione dei nessi logici"144. É importante observar, entretanto que, se de um lado, a presença do elemento onírico

\footnotetext{
"sprigiona immediatamente richiami che permettono quell'accesso simultaneo ai testi che ne rappresenta la chiave interpretativa, dall'altro delegittima parzialmente l'operazione letteraria, che, nata nella sfera del sogno (...), si prospetta come ipotesi di alterità. La letteratura viene dunque vista allo stesso tempo come completamento e alienazione" ${ }^{, 145}$.
}

\footnotetext{
${ }^{142}$ Piglia, R. Formas breves. cit., p. 107.

${ }^{143}$ Piglia, R. Formas breves. cit., p. 114 e 118.

${ }^{144}$ Surdich, L. "Il principio della letteratura, raccontare il sogno di un altro". In: I 'notturni' di Antonio Tabucchi. cit., p. 45: "vazios deixados descobertos pela abolição dos nexos lógicos".

${ }^{145}$ Storchi, Simona. "Sogni di sogni di Antonio Tabucchi: strategie della metanarrazione tra tradizione e postmoderno". In: Rorato, Laura e ___ (Org.) Da Calvino agli ipertesti. Prospettive della postmodernità nella letteratura italiana. Florença: Franco Cesati Editore, 2002. p. 166: "liberta imediatamente as ligações que permitem o acesso simultâneo aos textos que representam a sua chave interpretativa, por outro lado, deslegitima parcialmente a operação literária, que, nascida na esfera do sonho (...), projeta-se como hipótese de alteridade. Portanto, a literatura é vista ao mesmo tempo como conclusão e alienação".
} 


\title{
3.2. IL GIALLO: A FUNÇÃO INVESTIGATIVA DA ESCRITA.
}

"O leitor de contos policiais é alguém que lê com incredulidade, com desconfiança, uma

desconfiança especial”.

Jorge Luis Borges.

A presença do sonho é também uma temática fundamental do conto metaliterário "Rebus". O sonho se apresenta como uma das "possibilidades de resolução" para o enigma proposto pelo narrador. É também uma solução possível aos equívocos da realidade, um mecanismo que ajuda a preencher "i vuoti fra le cose" e estabelecer a "completezza"146. O conto se inicia com a narração deste sonho:

\begin{abstract}
"Stanotte ho sognato Miriam. Indossava una lunga veste bianca che da lontano sembrava una camicia da notte; avanzava lungo la spiaggia, le onde erano paurosamente alte e si frangevano in silenzio, doveva essere la spiaggia di Biarritz, ma era completamente deserta, io stavo seduto su una poltrona a sdraio, la prima di un'interminabile fila di poltrone deserte, ma forse era un'altra spiaggia, perché a Biarritz non mi ricordo poltrone come quelle, era solo l'idea di una spiaggia, e le ho fatto cenno con il braccio invitandola a sedersi, ma lei ha continuato a camminare come se non si fosse accorta di me, guardando fisso in avanti, e quando mi è passata vicino mi ha investito una folata di aria gelida, come un alone che si portava dietro: e allora, con lo stupore senza sorpresa dei sogni, ho capito che era morta" ${ }^{, 147}$.
\end{abstract}

Logo após, o narrador reflete sobre o significado deste sonho, contando a sua origem, e junto com a história que conta, propõe um jogo enigmático, em que a solução

\footnotetext{
${ }^{146}$ Tabucchi, A. "Rebus". In: Racconti. cit., p. 149: "os vazios entre as coisas"; "completude".

${ }^{147}$ Tabucchi, A. "Rebus". cit., p. 149: "Esta noite sonhei com Miriam. Vestia uma longa roupa branca que, de longe, parecia uma camisola. Avançava pela praia, as ondas eram perigosamente altas e se quebravam em silêncio, devia ser a praia de Biarritz, mas estava completamente deserta, eu estava sentado em uma espreguiçadeira, a primeira de uma interminável fila de espreguiçadeiras desertas, mas talvez fosse uma outra praia, porque não me lembro de cadeiras como estas em Biarritz, era apenas a ideia de uma praia. Acenei para ela com o braço, convidando-a a sentar-se, mas ela continuou a caminhar como se não tivesse percebido minha presença, olhando fixo adiante, e quando passou perto de mim, uma rajada de ar gelado me atingiu, como um halo que trazia atrás: e então, com o assombro sem surpresa dos sonhos, entendi que estava morta".
} 
permanece em aberto ou é delegada ao leitor. Este, por sua vez, deve assumir a tarefa de resolver esta charada, ou, ao menos, de atribuir um sentido, entre os vários possíveis, ao enigma. Ao final do conto, o leitor se mantém aprisionado ao fascínio do próprio enigma e acaba por descobrir o lado "obscuro" da realidade, já que este rebus "no ha soluzione, o ha una soluzione che è inevitabilmente quella che ebbe, e che io ignoro"148.

O protagonista, em um bar, conta a um interlocutor desconhecido sobre a misteriosa aventura que teria vivido com a mulher do sonho, Miriam, durante uma corrida de automóveis em Biarritz. A trama, tecida nos moldes do conto policial, é construída a partir da tentativa de assassinato desta mulher e do roubo de uma estatueta de um elefantinho, colocado sobre o capô de uma Bugatti Royale. O gosto de Tabucchi por personagens excêntricos e vidas malogradas se adensa nesta narrativa, combinandose a uma teia policial que consiste em uma busca investigativa não por respostas, mas sim por uma mensagem, um sinal, uma presença.

A história é contada a um companheiro de bar, um interlocutor identificado como Monsieur, a quem o narrador propõe o enigma. A existência deste interlocutor pressupõe marcas de oralidade no texto. A presença da segunda pessoa, do ouvinte da história, remete, por sua vez, ao leitor, que observa /lê a vida alheia:

\footnotetext{
"Ma poi perchè a Lei interessano i rebus, ha la passione dell'enigmistica o forse è solo la curiosità sterile di chi osserva la vita altrui?";

"Ah, ma Lei mi ha fatto bere troppo, Monsieur";

"Ma a lei perchè interessano le storie altrui?" 149.
}

Enquanto entre um copo e outro, conta sua história, o narrador reflete sobre o que é a vida, o amor, e procura definí-los, em um exercício metafísico e existencialista. Esboça, assim, algumas definições, tais como: a vida é uma viagem, um encontro perdido - "un appuntamento mancato"; assemelha-se aos fios entrelaçados de uma "tessitura"; ou então é uma engrenagem, com uma espécie de correia de transmissão que liga todas as peças; ou, por fim, uma estrada, cheia de altos e baixos:

\footnotetext{
${ }^{148}$ Tabucchi, A. "Rebus". cit., p. 150: "não tem solução, ou tem uma solução que é, inevitavelmente, aquela que teve, e que eu ignoro".

${ }^{149}$ Tabucchi, A. "Rebus". cit., respectivamente nas páginas 150, 162: "Mas porque os rebus interessam ao senhor, é apaixonado por enigmísitca ou é apenas, talvez, a curiosidade estéril de quem observa a vida dos outros?"; "Ah, o senhor me fez beber demais, Monsieur"; "Mas porque lhe interessam as histórias dos outros?".
} 
"La vita è un appuntamento, lo so di dire una banalità, Monsieur, solo che noi non sappiamo mai il quando, il chi, il come, il dove";

"Un appuntamento e un viaggio, anche questa è una banalità, mi riferisco alla vita, naturalmente, chissà quante volte è stato detto";

"E poi, sa come è la vita, è come una tessitura, tutti i fili si intrecciano";

"La vita è un ingranaggio, una rotella qua, una pompa là, e poi c'è una cinghia che collega tutto e trasforma l'energia in movimento, proprio come nella vita";

"La strada dietro di me fuggiva, davanti a me si apriva e io pensavo alla mia vita" 150 .

Estas cinco definições, enunciadas em meio à narração dos acontecimentos, mostram que o narrador tem consciência de seu processo narrativo, é um narrador que manipula seu leitor, oferecendo pistas (que depois se revelam falsas, ou que não servem para a reconstrução dos fatos) sobre a história que pretende contar. Com esse processo, o narrador instaura também um jogo intertextual e literário, pois a ideia de transmitir um saber enquanto se narra uma história, de passar adiante uma experiência adquirida e comunicável, presente no conto, parece dialogar com o conceito de narrador oral benjaminiano. Diz Walter Benjamin que o narrador oral "retira da experiência o que ele conta: sua própria experiência ou a relatada pelos outros. E incorpora as coisas narradas à experiência dos seus ouvintes" "151. A "experiência comunicável", no caso da narrativa tabucchiana, resume-se, todavia, a tentativas de explicar o acontecimento vivido, a definições vagas sobre o sentido da vida, o que esvazia o caráter "épico da verdade" narrada - "a sabedoria tecida na substância viva da existência", de que fala Benjamin. Essa incomunicabilidade narrativa caracteriza o romance moderno e seu narrador, pobre de experiências exemplares.

O narrador tabucchiano não conta um fato "exemplar", e sim, comunica ao seu ouvinte/leitor uma incompreensão sobre o sentido da própria experiência. Neste sentido,

\footnotetext{
${ }^{150}$ Tabucchi, A. "Rebus". cit., respectivamente nas páginas 149, 150, 151, 153 e 157: “A vida é um encontro, sei que digo uma banalidade, Monsieur, só que nós não sabemos nunca o quando, o quem, o como, o onde"; "Um encontro e uma viagem, isto também é uma banalidade, refiro-me à vida, naturalmente, quem sabe quantas vezes isto foi dito"; "E depois, sabe como é a vida, é como uma tecedura, todos os fios se entrelaçam"; "A vida é como uma engrenagem, uma rodinha aqui, uma bomba lá, e depois uma correia que liga tudo e transforma a energia em movimento, exatamente como na vida"; "A estrada atrás de mim fugia, diante de mim se abria, e eu pensava na minha vida".

${ }^{151}$ Benjamin, Walter. "O narrador. Considerações sobre a obra de Nikolai Leskov". In: Magia e técnica. Arte e política. Ensaios sobre literatura e história da cultura. Trad. Sergio Paulo Rouanet. $7^{a}$. ed. São Paulo: Ed. Brasiliense, 1994. (Obras escolhidas, vol.1) p. 201.
} 
nega e se distancia do narrador oral e se afirma mais como um narrador "jornalista", considerado por Silviano Santiago um tipo de narrador pós-moderno ${ }^{152}$, uma vez que se situa "fora" da história. Assim como acontece em "Piccoli equivoci senza importanza", o narrador é um mero observador dos fatos, que transmite uma informação ou que narra a experiência do outro de modo distanciado, a partir da observação de uma vivência alheia, não conseguindo apreender o saber da experiência para transmiti-lo ao outro.

Já a oralidade presente no conto, as referências ao ouvinte/leitor (expressa nos termos "Monsieur" e "Lei", por exemplo, formas de tratamento que se referem a uma segunda pessoa do discurso), mais que aproximar o evento narrado de uma história "exemplar", cria um efeito de paródia no texto. Como autor que conhece criticamente as estruturas narrativas, Tabucchi cria narradores declaradamente manipulativos, problematizando a inserção da subjetividade na narrativa. Portanto, em sua narrativa existe uma formalização estética da experiência, o que, via de regra, inviabiliza a presença de um narrador oral clássico. Desta forma, os textos tabucchianos são paródicos em sua relação intertextual com as tradições e com as convenções dos gêneros envolvidos ${ }^{153}$.

O mesmo pode ser dito em relação à presença do gênero policial no conto, que é subvertido e transgredido, por meio da problematização e da ruptura com as normas do gênero. A narrativa policial é, por definição, um gênero que substitui a intuição e o acaso pela precisão e pelo rigor lógico. De acordo com Tzvetan Todorov ${ }^{154}$, o gênero policial possui algumas convenções ou estruturas fixas, tais como: o fato de a narrativa se iniciar com um crime já acontecido; a figura do detetive, que investiga e reconstrói o fato, sendo que sua inteligência racional é também um dos elementos canônicos da narrativa policial; o foco narrativo é centrado no amigo/narrador-confidente que acompanha as peripécias do detetive; além de outros personagens fixos tais como o criminoso, que encarna o mal, e a vítima. A narrativa policial se apresenta, em geral, como um problema intelectual a ser resolvido pelo detetive e pelo leitor ${ }^{155}$.

\footnotetext{
${ }^{152}$ Santiago, S. “O narrador pós-moderno”. In: Nas malhas da letra. São Paulo, Companhia das Letras, 1989. pp. 40 e ss.

${ }^{153}$ Hutcheon, L. Poética do Pós-Modernismo. cit., pp. 28 e ss.

${ }^{154}$ Todorov, T. "Tipologia do romance policial". In: Poética da prosa. Trad. Claudia Berliner. São Paulo: Martins Fontes, 2003. p. 67 e ss.

${ }^{155}$ Ângelo, A. P. “Tradição e transgressão no conto policial de Jorge Luis Borges”. Tese apresentada ao Centro de Comunicação e Expressão da Universidade Federal de Santa Catariana, 2006. pp. 6 e ss.
} 
Todorov define o policial clássico ou de enigma a partir da existência de duas histórias constantes, a do crime e a da investigação: "A primeira, a do crime, conta 'o que de fato aconteceu', ao passo que a segunda, a da investigação, explica 'como o leitor (ou o narrador) tomou conhecimento dos fatos" "156. Todorov faz distinção ainda entre o romance policial e aquele noir, criado nos Estados Unidos nos anos de 1930, pouco antes da Segunda Guerra, um tipo de romance policial que funde as duas histórias ou suprime a primeira e dá vida à segunda. Não se relata mais um crime anterior ao momento da narrativa, esta coincide com a própria ação ${ }^{157}$.

Essas definições de Todorov nos servem para pensar a questão policial na narrativa tabucchiana. Como dissemos, existe nesta narrativa um embrião da literatura policial, mas como ocorre também em obras de outros autores contemporâneos inclusive do próprio Borges, autor a quem Tabucchi se filia em termos de temática - o conto subverte a lógica do gênero policial, seja por meio da trama, seja por meio da transgressão ou ruptura com as normas do gênero.

A trama se inicia com a entrada de Miriam em uma oficina situada em um bairro menos nobre de Paris, próximo de Porte Saint-Denis. Esta oficina pertence ao narrador protagonista, um jovem mecânico, ex-estudante de Letras, e corredor de rallys, que passa o tempo procurando e consertando automóveis antigos. O protagonista tem como sócio, Albert, "un omino minuto che il bancone del bar aveva reso malinconico e rideva solo quando aveva bevuto un bicchiere in più" ${ }^{158}$. Ex-corredor de rally, Albert ajudava o narrador a procurar e restaurar automóveis antigos, chegando, inclusive, a obter o automóvel que teria pertencido a Proust, por meio de seu motorista Agostinelli - com quem Proust teria feito um giro pela Normandia, para ver as catedrais góticas, publicando suas impressões em um artigo para o Le Figaro, em 1907.

Conforme o narrador, Albert era um pouco "filósofo" - "tutti i buoni meccanici lo sono", pois, ao se estudar os automóveis, "si capiscono tante cose, la vita è un ingranaggio, una rotella qua, una pompa là, e poi c'è una cinghia che collega tutto e

\footnotetext{
${ }^{156}$ Todorov, T. "Tipologia do romance policial". cit., p. 67.

${ }^{157}$ Todorov, T. "Tipologia do romance policial". cit., p. 69.

${ }^{158}$ Tabucchi, A. "Rebus". cit., p. 150: "um homenzinho muito pequeno, o qual o balcão do bar tornara melancólico, que ria apenas quando bebia um copo a mais".
} 
trasforma l'energia in movimento, proprio come nella vita" ${ }^{159}$. Assim, os dois passam a compartilhar a mesma filosofia de vida, ou seja, encaram a existência como um motor de automóvel, uma engrenagem, mas o fluxo contínuo dos acontecimentos e a passagem do tempo os impossibilitam de encontrar a "correia" que liga tudo. São personagens nostálgicos, que veem o passar dos tempos como degradação, como perda de uma "aura" em favor da reprodução técnica e da mercadoria ${ }^{160}$ :

\begin{abstract}
"Erano altri tempi, non voglio fare il nostalgico, ma erano altri tempi davvero, provi a guardare le automobili di oggi, hanno il motore tutto compresso, rinchiuso in un fazzoletto, non c'è neppure lo spazio per smontare il carburatore" ${ }^{" 161}$.
\end{abstract}

A personagem Miriam se apresenta ao narrador como sendo a "contessa du Terrail”, que deveria chegar até a praia de Biarritz. O narrador, pensando se tratar de uma piada, responde dizendo ser o "marchese di Carabas, ma di norma non esco mai dalle mie proprietà” ${ }^{\prime 62}$. Com este epíteto, referência ao marquês de Carabás do conto de fadas $O$ Gato de Botas, de Charles Perrault, o narrador expressa sua incredulidade em relação à história da mulher. Além disso, este era o pseudônimo com o qual o narrador teria assinado dois artigos publicados em uma revista "ignóbil", sobre as "impressões de Proust em um automóvel". Estes artigos, partes de sua tese não publicada, teriam permitido o encontro entre Albert e o narrador, em "Chez Albert", o bar de Albert, em Saint-Denis.

Miriam pede ao narrador que a acompanhe a Biarritz dizendo-lhe que estava sendo perseguida e que queriam matá-la, mas ele não acredita, e prefere não se envolver na intrigante história. Poucos dias depois, aparece em seu escritório o conde, que lhe pede para recusar a proposta de Miriam, recuperar seu velho automóvel, uma Bugatti

\footnotetext{
${ }^{159}$ Tabucchi, A. "Rebus". cit., p. 153: "todos os bons mecânicos o são"; "se entendem tantas coisas, a vida é como uma engrenagem, uma rodinha aqui, uma bomba lá, e depois uma correia que liga tudo e transforma a energia em movimento, exatamente como na vida".

${ }^{160}$ Benjamin, Walter. “A obra de arte na era de sua reprodutibilidade técnica”. In: Magia e técnica. Arte e política. Ensaios sobre literatura e história da cultura. Trad. Sergio Paulo Rouanet. $7^{\text {a }}$. ed. São Paulo: Ed. Brasiliense, 1994. (Obras escolhidas, vol.1).

${ }^{161}$ Tabucchi, A. "Rebus". cit., p. 150: "Eram outros tempos, não quero dar uma de nostálgico, mas eram outros tempos de verdade, tente olhar os automóveis de hoje, têm um motor todo compacto, fechado em um peça pequena, não têm nem mesmo espaço para desmontar o carburador".

${ }^{162}$ Tabucchi, A. "Rebus". cit., p. 150: “condessa du Terrail”; "marquês de Carabás, mas via de regra, não saio nunca das minhas propriedades".
} 
Royale de 1927, e levá-la a Biarritz, para participar de um rally em San Sebastian. O narrador mente, afirmando não conhecer Miriam e não ter recebido nenhuma proposta de trabalho. Após a partida do conde, ele telefona ao hotel em que se encontravam hospedados, e deixa uma mensagem pessoal à condessa, dizendo se tratar do "marchese di Carabas".

Albert e o narrador vão buscar a Bugatti e se emocionam com a visão do automóvel, em boas condições, devendo trocar poucas peças, como as rodas e o escapamento. Notam, entretanto, que faltava ao capô o elefantinho de prata, símbolo da marca Bugatti: "un vero simbolo, misterioso da decifrare come tutti i simboli" 163. Restauram o automóvel, fazem uma réplica em madeira da escultura. E então, o narrador parte para a viagem, acompanhando Miriam. Nas curvas das estradas francesas, o narrador descobre a beleza de Miriam, e experimenta, pela primeira vez na vida, o amor verdadeiro:

"La strada dietro di me fuggiva, davanti a me si apriva e io pensavo alla mia vita, alla mia accidia, a quello che aveva detto Albert, e sentii vergogna per non aver mai conosciuto l'amore. Non quello fisico, naturalmente, quello c'era stato come in tutte le vite: ma l'amore vero, quello che brucia dentro e si propaga fuori e gira come un motore mentre le ruote fanno il cammino" 164 .

Para chegar a Biarritz, fazem um percurso diferente do habitual, "absurdo", mas necessário, segundo Miriam, desviando de algumas cidades e passando por outras, inclusive pela cidade em que teria vivido a mãe de Miriam. Em uma destas cidades desconhecidas, os dois se entregam à paixão. No sábado, chegam a Biarritz, e no dia seguinte, domingo, acontece a corrida de automóveis, que previa costumes de época, cada motorista deveria usar trajes que correspondessem à época de produção de seu carro.

\footnotetext{
${ }^{163}$ Tabucchi, A. "Rebus". cit., p. 155: "um verdadeiro símbolo, misterioso de decifrar, como todos os símbolos".

${ }^{164}$ Tabucchi, A. "Rebus". cit., p. 157: “A estrada atrás de mim fugia, diante de mim se abria, e eu pensava na minha vida, na minha inércia, naquilo que tinha dito Albert, e senti vergonha por não ter conhecido nunca o amor. Não aquele físico, naturalmente, aquele tinha existido como em todas as vidas: mas o amor verdadeiro, aquele que queima por dentro e se propaga por fora e gira como um motor enquanto as rodas fazem o caminho".
} 
Os dois partem na Bugatti por estradas sinuosas que costeam o oceano até San Sebastian. Durante a corrida, outro automóvel bate na traseira da Bugatti, tentando jogálos no precipício, mas eles conseguem escapar do acidente e chegam a San Sebastian. O automóvel sofre apenas alguns danos facilmente reparáveis.

Quando estão retornando à França, um reflexo solar sobre a escultura símbolo da Bugatti faz com que o narrador perceba que o elefantinho de madeira havia sido trocado por outro de metal ou de prata. O narrador pergunta a Miriam o que havia dentro da estatueta, mas ela empalidece e não responde. Ao invés disso, promete lhe contar tudo à noite, após a chegada do marido. Voltam para o hotel, e após despertar de um sono agitado, com sonhos confusos, o narrador, aproveitando-se do fato de Miriam estar no banho, revira sua bolsa e encontra uma pistola ali dentro. Ele desconfia que a mulher talvez estivesse com medo do marido e, com intenção de ameaçar e descobrir o motivo desta perseguição, sai para buscar o conde na estação, levando consigo a pistola. Despede-se de Miriam, que promete encontrá-lo mais tarde na praia, às nove e meia.

Na estação, o conde não aparece. Tomado pela ansiedade, o narrador segue para o hotel onde o conde deveria se hospedar e descobre não existir nenhum registro ali. Procura Miriam no hotel em que a havia deixado e também não a encontra. Descobre que ela havia partido na Bugatti, pouco depois dele. Ele segue para a praia de Biarritz, senta-se em uma cadeira de praia, das muitas que estavam ali, enfileiradas, voltadas para o mar e espera Miriam até meia-noite. A condessa não aparece e a narrativa termina com a imagem da praia deserta e a espera vã do narrador - a mesma imagem que o narrador descreve no começo do conto, a propósito de seu sonho.

$\mathrm{O}$ final da aventura permanece em suspenso. $\mathrm{O}$ encontro com Miriam não acontecerá nunca, nem mesmo em sonho, pois, neste, o narrador vê passar ao seu lado apenas o seu fantasma, o seu espectro, dirigindo-se ao mar, sem percebê-lo, como se ele não existisse, ou pertencesse a outro universo.

O episódio narrado é regido pelo acaso, uma parte da história não é conhecida pelo leitor e nem pelo narrador, que não consegue descobrir o paradeiro da mulher e seus segredos. Anos depois, ainda tomado pelo mistério, coloca um curioso anúncio no jornal Le Figaro com a mensagem: "Elefante perduto cerca Bugatti del Ventisette"165.

\footnotetext{
${ }^{165}$ Tabucchi, A. “Rebus”. cit., p. 162: "Elefante perdido procura Bugatti de 1927”. (Grifos do autor).
} 
O movimento do narrador, sua busca por respostas, não significa um encontro, mas, ao contrário, o que predomina é o desencontro - "l'appuntamento mancato". Ao ouvinte/leitor, assim como ao narrador, não é dada a possibilidade de descobrir o motivo, "o quando, o quem, o onde e o como" da aventura. Ambos são "incapazes" de preencher os vazios da narrativa: "Ma a lei perchè interessano le storie altrui? Anche lei deve essere incapace a riempire i vuoti fra le cose. Non le sono sufficienti i suoi propri sogni?" 166 . Os sonhos se colocam, aqui, como possibilidade de completude, porque possuem a capacidade de restituir um significado que escapa.

Do ponto de vista temático, a narrativa instaura uma dúvida, uma interrogação que se estende ao leitor. Do ponto de vista formal, todavia, a substituição do rigor e da precisão lógica que caracterizam a narrativa policial pelo acaso e pelo enigma cria um problema estrutural, já que as convenções e/ou normas do gênero são transgredidas. Como vimos, a proposição do enigma emoldura a trama policial. A narrativa não se inicia com um crime já acontecido. Não existe a figura do detetive, que investiga e reconstrói o fato, este papel cabe ao narrador, sendo que sua "inteligência racional" não dá conta de resolver os mistérios da aventura narrada. $\mathrm{O}$ foco narrativo é centrado no próprio narrador, que não conhece os detalhes da trama. Além disso, o crime não é concluído, pois não sabemos se Miriam será realmente assassinada e se o marido é ou não um criminoso que a persegue.

Da estrutura do "giallo", mantém-se o problema intelectual, o mistério e o enigma a ser resolvido pelo detetive-narrador e por seu ouvinte-leitor. A solução, entretanto, pertence ao universo onírico, estende-se para além da lógica racional, que não consegue explicar os acasos da vida e o sentido da aventura. $\mathrm{Na}$ embriaguez dos sentidos, quando se bebe um pouco, a realidade se simplifica e é possível estabelecer as relações entre as coisas:

\footnotetext{
"Ah, ma lei mi ha fatto bere troppo, Monsieur, però in quanto a bicchieri è una buona compagnia. Sa, a volte, quando si è bevuto un po', la realtà si
}

\footnotetext{
${ }^{166}$ Tabucchi, A. "Rebus". cit., p. 162: "Mas porque lhe interessam as histórias dos outros? O senhor também deve ser incapaz de preencher os vazios entre as coisas. Não lhe são suficientes os seus próprios sonhos?".
} 
semplifica, si saltano i vuoti fra le cose, tutto sembra combaciare e uno dice: ci sono. Come nei sogni' ${ }^{\prime 167}$.

As últimas considerações do narrador reviram do avesso toda a lógica do conto. Assim como em "Piccoli equivoci senza importanza", o desejo de simplificação da realidade prevalece. A conclusão da investigação, que no gênero policial é a coisa mais importante, não existe, é delegada ao leitor a tarefa de estabelecer os nexos entre as partes da história.

Considerando os dois romances "gialli" de Tabucchi, Notturno indiano e Il filo dell'orizzonte, publicados em 1984 e 1986, respectivamente, podemos perceber nestes um falimento do gênero policial na literatura tabucchiana, pois a mistura das formas, o jogo do avesso que desorienta o leitor, os finais abertos que suspendem a investigação, não se encaixam na ótica do romance policial, tornando estas narrativas fluidas e permeáveis. O que aqui se vê, é o predomínio de zonas fronteiriças entre um gênero e outro, o questionamento acerca da própria forma literária. Mais que romances policiais, Notturno indiano e Il filo dell'orizzonte, são romances fronteiriços, que se constroem na intersecção de outros gêneros, tais como o romance filosófico, o existencialista, o romance de formação, o policial.

O conto "Rebus" também caminha nessa direção. Mistura formas e gêneros, é construído na fronteira, no limite entre as convenções de um gênero e outro. É um conto que investiga uma aventura de suspense, de base noir ou detetivesca, mas também reflete filosoficamente sobre a condição do homem contemporâneo; que tenta definir a existência e se perde nas imprecisões do acaso e na impossibilidade de explicar o sentido da vida e da própria experiência. Em relação ao foco narrativo, o conto apresenta um narrador que tenta se assemelhar ao narrador oral clássico, mas os "bons conselhos" se resumem a charadas sem solução, apresentadas durante uma conversa de bar.

A narrativa policial tabucchiana, desta forma, afirma-se negativamente como desconstrução, como "antigiallo" construído a partir do "giallo", mas com uma trama que "viene sovvertita, insieme riproposta e trasgredita, perché a perdere il loro ruolo

\footnotetext{
${ }^{167}$ Tabucchi, A. "Rebus". cit., p. 162: "Ah, mas o senhor me fez beber demais, Monsieur, porém, de copo, é uma boa companhia. Sabe, às vezes, quando se bebe um pouco, a realidade se simplifica, os vazios entre as coisas se revelam, tudo parece corresponder e alguém diz: estou aqui. Como nos sonhos".
} 
canonico sono innanzitutto i personaggi agenti" ${ }^{168}$. Na esteira de escritores como Gadda e Sciascia, a narrativa policial em Tabucchi pertence a um filão que, segundo Giuseppe Petronio, pode ser considerado experimental e problemático ${ }^{169}$, que se distancia do modelo tradicional, inglês e norte americano.

Para Tabucchi, entretanto, sua opção pela literatura policial está associada ao caráter investigativo deste gênero literário que, conforme o escritor afirma em $L a$ gastrite di Platone, consiste no fundamento da escrita - a função interrogativa da literatura, o exercício da faculdade da dúvida, de se colocar questões que podem permanecer sem resposta. O desejo de completude, expresso pelo narrador de "Rebus" na definição de que "la vita è come una tessitura, tutti i fili si intrecciano, è questo che un giorno vorrei capire, vorrei vedere tutto il disegno" 170 é, assim, uma declaração de incompreensão do enigma. O desconhecimento da tecedura que entrelaça os fios da vida é uma afirmação do narrador de que este não é um bom “detetive", pois, ao revelar não compreender o "desenho" e não poder resolver a charada, o narrador confessa a sua incapacidade de resolução dos mistérios. Afirma, entretanto, a função investigativa da literatura. Diz Tabucchi que com a escrita de Il filo dell'orizzonte, teria se confrontado, pela primeira vez, com uma literatura interrogativa:

\begin{abstract}
"quella gialla, che io amo molto, sia nella sua forma più popolare - i gialli che escono settimanalmente - che in quella di alto livello letterario come potrebbero essere i 'gialli' scritti da Sciascia e Dürrenmatt. Ho poi utilizzato questo modello anche in Pereira, che in fondo è un romanzo giallo, con la struttura di una storia poliziesca modellata secondo un riferimento a un'autorità, secondo quel modello di ricerca e di interrogazione che è caratteristico della letteratura poliziesca"171.
\end{abstract}

\footnotetext{
${ }^{168}$ Orvieto, P. “1985-1991. Gli anni del giallo e del suo 'oscuramento'. Dal noir esistenziale a quello civile”. In: I 'notturni' di Antonio Tabucchi. cit., pp. 87 e 88: "é subvertida, ao mesmo tempo, reproposta e transgredida, porque, antes de tudo, são os personagens agentes que perdem os seus papéis canônicos". ${ }^{169}$ Petronio, Giuseppe. Sulle tracce del giallo. Roma: Gamberetti Editrice, 2000. p. 115.

${ }^{170}$ Tabucchi, A. "Rebus". cit., p. 151: “A vida é como uma tecedura, todos os fios se entrelaçam, é isso que um dia gostaria de entender, gostaria de ver todo o desenho".

${ }^{171}$ Tabucchi, A. Conversazioni con Antonio Tabucchi. Dove va il romanzo? Citado por Elisabetta Baccheretti, “Tabucchi, almost noir”. In: I 'notturni' di Antonio Tabucchi. cit., p.73: “Aquela policial, que eu amo muito, seja na sua forma mais popular - os policiais que saem semanalmente - ou naquela de alto nível literário, como poderiam ser os 'policiais' escritos por Sciascia e Dürrenmatt. Depois utilizei este modelo também em Pereira que, no fundo, é um romance policial, com a estrutura de uma história policial modelada segundo uma referência a uma autoridade, segundo aquele modelo de pesquisa e de interrogação, que é característico da literatura policial".
} 
Essas afirmações do autor sobre o uso da narrativa policial mostram que

\begin{abstract}
"La capacità di indagine [di Tabucchi] sembrava arrestarsi ad un certo punto di fronte a storie difficili da collegare in un nesso logico, dove la casualità si trasforma talvolta in destino, forse per una 'sotterranea sfiducia nella ragione, o magari per una forma di pavidità, un'incapacità di andare fino in fondo'. L'enigma del reale sembrava allora sottrarsi comunque ad ogni possibile ricostruzione logica. Ma il Tabucchi degli anni novanta (...) sembra impegnarsi soprattutto nella definizione della funzione investigativa della scrittura, del rapporto tra la letteratura e la società civile o la storia" ${ }^{, 172}$.
\end{abstract}

De fato, com os romances Sostiene Pereira e La testa perduta de Damasceno Monteiro, Tabucchi parece direcionar suas questões temáticas e estruturais para a criação de uma narrativa que se baseia, sobretudo, no empenho do escritor com a realidade, com a história e a sociedade. Sem abandonar algumas temáticas que são importantes para a sua primeira fase narrativa, entre elas a presença do sonho, mas buscando construir uma escrita que interrogue a realidade, em que a função interrogativa do intelectual esteja viva e presente em suas dimensões política, histórica e social. Nesta literatura, "il sapere è un metodo, non una certezza e, più che fondarsi sul noto, procede verso il non conosciuto, in un percorso di progressiva detection"173.

\footnotetext{
${ }^{172}$ Baccheretti, E. "Tabucchi, almost noir". cit., p.73: "A capacidade de pesquisa [de Tabucchi] parecia se deter, em certo ponto, diante de histórias difíceis de unir em um nexo lógico, onde a casualidade se transforma, às vezes, em destino, talvez devido a uma 'subterrânea desconfiança da razão, ou talvez, por uma forma de timidez, uma incapacidade de ir até o fim'. O enigma do real parecia se subtrair, de algum modo, a toda reconstrução lógica possível. Mas o Tabucchi dos anos de 1990 (...) parece se empenhar, principalmente, na definição da função investigativa da escrita, da relação entre a literatura e a sociedade civil ou a história".

${ }^{173}$ Baccheretti, E. "Tabucchi, almost noir”. cit., p.75: "o saber é um método, não uma certeza e, mais que se basear sobre o conhecido, prossegue em direção ao desconhecido, em um percurso de progressiva detection".
} 


\subsection{L'APPUNTAMENTO MANCATO}

E não está a cidade mais do que repleta de templos, praças cercadas, santuários nacionais, para poder penetrar indivisa, com cada paralelepípedo, com cada tabuleta, com cada degrau, com cada pórtico, no sonho do transeunte?

Walter Benjamin

A presença de uma figura feminina enigmática, um intrigante anúncio de jornal que permanece sem resposta e o desencontro do personagem protagonista com a mulher amada são alguns dos temas presentes em "Rebus" retomados pelo conto "Any where out of the world". Neste, como em quase todos os contos da coletânea Piccoli equivoci senza importanza, a atmosfera de mistério se mantém. O título do conto é emprestado de um poema de Charles Baudelaire, de O Spleen de Paris: pequenos poemas em prosa $^{174}$. Nesta narrativa poética, o poeta dialoga com a própria alma, sugerindo-lhe lugares exóticos e diferentes em que sua alma poderia habitar, e um destes lugares é Lisboa, cidade que possui "uma paisagem de luz e de mineral"175, onde também se passa a narrativa de Tabucchi.

O narrador e protagonista, um professor francês de um centro linguístico em Lisboa, descreve-se como um "rosto anônimo" perdido em uma "multidão de rostos anônimos": "Sono un volto anonimo in questa moltitudine di volti anonimi"176. É um caminhante solitário, que percorre as ruas da cidade, passeia pelas suas praças, cafés e restaurantes. Enquanto caminha à beira do Tejo e conversa consigo mesmo, tenta compreender um inesperado anúncio de jornal, uma frase perdida "in questo vasto mondo pieno di frasi e di oggetti e di volti" ${ }^{\prime 77}$. Quatro anos antes, ele teria trocado juras de amor com uma misteriosa mulher, Isabelle, provavelmente casada, que não teve

\footnotetext{
${ }^{174}$ Tradução brasileira de Leda Tenório da Motta, Editora Imago, 1995.

${ }^{175}$ Baudelaire, C. "Anywhere out of the world. Em algum lugar fora do mundo" In: O Spleen de Paris: pequenos poemas em prosa. Trad. Leda Tenório da Motta. Rio de Janeiro: Editora Imago, 1995. p. 143.

${ }^{176}$ Tabucchi, A. "Any where out of the world". In: Racconti. cit., p. 190: "Sou um rosto anônimo nesta multidão de rostos anônimos".

${ }^{177}$ Tabucchi, A. "Any where out of the world". cit., p. 190: "neste vasto mundo cheio de frases e de objetos e de rostos".
} 
coragem de abandonar o matrimônio para acompanhá-lo. Nas juras de amor, nunca cumpridas, os dois tinham prometido se encontrar um dia em Lisboa. O sinal para este encontro seria o anúncio com o título do poema baudelairiano.

A narrativa é repleta de citações de Baudelaire, assim como de alusões à figura do poeta Fernando Pessoa ${ }^{178}$, poetas que vagueiam pelas ruas da cidade, descrevendo as sensações experimentadas durante estes passeios. Tabucchi descreve o percurso de seu protagonista por Lisboa, em meio a seus devaneios, recordações e sonhos, mostrando a inquietação que este sente ao perambular pela cidade, exatamente como fazem os poetas que cita.

É no caminhar pela cidade, com suas praças, seus transeuntes, seu ritmo alucinante, que o narrador vivencia um grande tormento, mas também uma sensação de liberdade, "bella e superflua, come un amore rifiutato"179. É na cidade que o narrador pode vivenciar, em meio a uma multidão de desconhecidos, o "fascínio da distância"180, o encanto de ser um entre tantos, um rosto anônimo na multidão:

\footnotetext{
"In una grande città come questa, con le sue piazze, e la metropolitana, e la gente che cammina frettolosa uscendo dagli impieghi, i tram, le automobili, i giardini, e poi il fiume placido sul quale scivolano al tramonto i battelli verso la foce" ${ }^{\prime 181}$.
}

Lisboa, a cidade pessoana, torna-se, assim,

"o espaço 'out of the world' que provoca no protagonista, que não possui
nome, um grande desassossego. Sob a atmosfera do spleen baudelairiano, o
protagonista percorre a cidade, e seu deambular se confunde com o traçado
das ruas, praças, com o movimento dos carros, do metrô. A cidade se

\footnotetext{
${ }^{178}$ Una sola moltitudine é o título da coletânea de poemas de Fernando Pessoa traduzidos para o italiano por Antonio Tabucchi, título que resgata a personalidade multíplice de Pessoa. O diálogo intertextual se estabelece também pela referência ao Livro do desassossego, do heterônimo Bernado Soares; os sentimentos que o protagonista experimenta ao caminhar por Lisboa remetem àqueles de Soares, suas percepções e inquietações em relação à cidade portuguesa, como bem nota Cátia Berlini Andrade, no ensaio "Flâneurs em Lisboa: Pessoa, Saramago e Tabucchi”. In: Visões poéticas do espaço. Ensaios. Org. Patricia Peterle et alli. Assis: FLC/UNESP Publicações, 2008.

${ }^{179}$ Tabucchi, A. "Any where out of the world". cit., p. 190: "bela e supérflua, como um amor rejeitado".

${ }^{180}$ Benjamin, W. "Sobre alguns temas em Baudelaire". In: Charles Baudelaire: um lírico no auge do capitalismo. Trad. José C. M. Barbosa e Hemerson A. Baptista. São Paulo: Editora Brasiliense, 1989. (Obras escolhidas, v. 3). p. 143.

${ }^{181}$ Tabucchi, A. "Any where out of the world". cit., p. 189: "Em uma grande cidade como esta, com as suas praças, e o metrô, e a gente que caminha apressada saindo dos empregos, o bonde, os automóveis, os jardins, e então o rio plácido, sobre o qual deslizam, ao pôr-do-sol, os barcos em direção à foz".
} 
transforma em personagem cumprindo um papel fundamental no processo de busca desse flâneur tabucchiano" 182 .

Sentado em um café, como costuma fazer todos os dias, o narrador lê as notícias do jornal, o caderno de esportes e o de cultura, percorre distraidamente os classificados. Enquanto lê as notícias, vai refletindo sobre os acontecimentos ao seu redor e no mundo: o futebol, o cinema com suas estreias e reprises, o mercado de trabalho. As manchetes e anúncios são inseridos na narrativa em forma de colagem, e a referência ao universo extraliterário, aos poucos, adentra o universo literário, atribuindo-lhe uma dimensão temporal presente. Repentinamente, entre os anúncios dos classificados, depara uma frase que conhecia muito bem. Aturdido, relê a frase várias vezes. Sente um estranho sabor na boca e pensa que se trata de uma horrível coincidência, uma mensagem ou uma charada do acaso:

\footnotetext{
"non è possibile, pensi, è un'orribile coincidenza; e poi valuti la parola 'orribile' e pensi: è solo una coincidenza, é solo un caso, un piccolo caso fra i miliardi di casi che ci sono a questo mondo, una cosa che sta succedendo" ${ }^{\text {"183 }}$.
}

A frase lida no jornal, "Any where out of the world", que deixa o protagonista nervoso e agitado, é o título do poema de Baudelaire, mencionado anteriormente. É a "frase deslocada", perdida nos vãos do tempo, uma mensagem do passado, talvez publicada ali por um erro de um tipógrafo distraído, que aciona imediatamente a memória literária deste personagem-leitor:

\footnotetext{
"Ma tu non hai bisogno di sapere altro, perché la frase si trascina dietro, come un fiume in piena trascina i detriti, rottami di parole che la tua memoria va ordinando chiaramente, con una calma che ti gela" ${ }^{, 184}$.
}

\footnotetext{
${ }^{182}$ Andrade, C. "Flâneurs em Lisboa: Pessoa, Saramago e Tabucchi". In: Visões poéticas do espaço. Ensaios. cit., p. 97.

${ }^{183}$ Tabucchi, A. "Any where out of the world". cit., p. 191: "não é possível, você pensa, é uma horrível coincidência; e depois avalia a palavra 'horrível' e pensa: é apenas uma coincidência, é apenas um acaso, um pequeno acaso entre os bilhões de acasos que existem neste mundo, uma coisa que está acontecendo". ${ }^{184}$ Tabucchi, A. "Any where out of the world". cit., p. 192: "Mas você não precisa saber outra coisa, porque a frase se arrasta para trás, como a cheia de um rio arrasta os detritos, destroços de palavras que a sua memória vai ordenando claramente, com uma calma que lhe gela".
} 
Desnorteado, o narrador relembra os versos iniciais do poema, que lhe afloram vivamente à memória: "Esta vida é um hospital em que cada doente é possuído pelo desejo de mudar de leito. Este queria sofrer ao pé do fogareiro, aquele melhorar bem junto da janela"185. Esta recordação, a memória de palavras que retornam e se acendem na sua mente como "piccoli fari nella notte" ${ }^{186}$, como a força de uma ilusão ou de um "consolo desencantado", assinalam a distância espacial e temporal do caso de amor nunca resolvido no passado. O narrador observa a data do jornal -22 de setembro, e pensa que também esta data é outra coincidência: a mesma frase e a mesma data, engolidas pelo passado, mas nunca desaparecidas completamente, permaneceram ali, soterradas pelas camadas do tempo, e agora, com violência, ressurgem na memória.

A citação textual dos escritos de Baudelaire, destacada em francês, língua-mãe do personagem, é um indício, de acordo com Ceserani, da importância que Tabucchi atribui a esses textos de referência e um aviso ao leitor de que devem ser levados em consideração:

\begin{abstract}
"non solo quello che è stato concordato come eventuale messaggio fra i due protagonisti, non solo il contenuto stesso di quel testo, che contiene un preciso riferimento alla città di Lisbona e al bisogno di fuga verso luoghi esotici dei due amanti, ma anche altri testi, che vengono utilizzati per esempio per descrivere la scena dell'ultimo incontro: la camera, la finestra, le posizioni dei due corpi, tutti attraverso testi baudelairiani" ${ }^{187}$.
\end{abstract}

O conto se utiliza de uma colagem de textos do poeta francês, em especial do Spleen de Paris. É um mosaico, uma composição feita de fragmentos, em que a evocação do poema se dá internamente à narrativa, pois o protagonista é também o leitor que relembra o poema, retirando-o de sua memória literária. Esta lembrança, por

\footnotetext{
${ }^{185}$ Baudelaire, C. "Anywhere out of the world. Em algum lugar fora do mundo" In: O Spleen de Paris: pequenos poemas em prosa. cit., p. 143.

${ }^{186}$ Tabucchi, A. "Any where out of the world". cit., p. 192: "pequenos faróis na noite". Expressão presente também no livro Donna di Porto Pim, retirada, segundo o autor, da obra de Chateaubriant: "Durante muito tempo carreguei na memória uma frase de Chateaubriand: Inutile phare de la nuit. Acredito que sempre lhe atribuí um poder de consolo desencantado: como quando nos agarramos a alguma coisa que se revela um inutile phare de la nuit e no entanto nos permite fazer alguma coisa só porque acreditávamos em sua luz: a força das ilusões". In: Mulher de Porto Pim, cit., p.32

${ }^{187}$ Ceserani, R. "Qualche considerazione sulla modernità liquida”. In: La modernità letteraria. cit., p. 19: "não apenas o que foi combinado como eventual mensagem entre os dois protagonistas, não apenas o conteúdo desse texto, que contém uma referência precisa à cidade de Lisboa a à necessidade de fuga dos dois amantes para lugares exóticos, mas também outros textos, que são utilizados, por exemplo, para descrever a cena do último encontro: o quarto, a janela, as posições dos dois corpos, todos filtrados pelos textos baudelairianos".
} 
sua vez, auxilia no resgate de sua história de amor, já que se trata de leituras feitas junto da mulher amada. Após trazer para a sua memória o poema, o protagonista se põe a caminhar pela cidade feita de mármore, como "anime inquiete che portano a passeggio $\mathrm{i}$ loro corpi insonni" ${ }^{188}$, encarnando, assim, a melancolia e a flânerie do poeta caminhante. Acrescente-se ainda a esta melancolia baudelairiana, a "saudade" pessoana, uma equivalente portuguesa do "spleen" francês, alma ou "categoria do espírito"189, que deriva do confronto direto com a cidade portuguesa e expressa a experiência da solidão do personagem:

"La città di Lisbona, oltre che il luogo del desiderio e dell'attrazione esotica, è il luogo della lentezza e della saudade. Lì le storie si adattano al ritmo lento dello scorrere del Tago, sembrano a volte risalire all'indietro, entrare in uno stato di sospensione" ${ }^{\prime 190}$.

Esse confronto entre o "spleen" de Baudelaire e a saudade portuguesa é feita pelo próprio autor, em uma de suas entrevistas. Nesta, conforme nota Anna Dolfi, Tabucchi vê a França como duplo ou reverso de Portugal; Paris como um reflexo especular da capital portuguesa e o "spleen" como face complementar e idêntica da "saudade"

\begin{abstract}
“Alla 'saudade' non è estraneo lo 'spleen' baudeleriano o comunque un male esistenziale. Indica sostanzialmente la condizione di un soggetto che si trova in una situazione di mancanza. Alcuni dei miei personaggi ne sono affetti. Mi piacciono i personaggi che sono monchi, che vivono in una situazione di privazione che è per loro continuo motivo di malessere" ${ }^{\text {192 }}$.
\end{abstract}

\footnotetext{
${ }^{188}$ Tabucchi, A. "Any where out of the world". cit., p. 19 3: "Almas inquietas que levam seus corpos insones para passear". Note-se neste trecho uma possível definição da palavra flâneur, utilizada pelo autor.

${ }^{189}$ Cf. Dolfi, Anna. "Lo spleen di Parigi e il senso di colpa". In: Gli oggetti e il tempo della saudade. cit., pp. 43 e ss.

${ }^{190}$ Ceserani, R. "Qualche considerazione sulla modernità liquida". In: La modernità letteraria. cit., p. 21: "A cidade de Lisboa, além do lugar do desejo e da atração exótica, é o lugar da lentidão e da saudade. Ali, as histórias se adaptam ao ritmo lento do escorrer do Tejo, parecem, às vezes, voltar para trás, entrar em um estado de suspensão".

${ }^{191}$ Cf. Dolfi, Anna. "Lo spleen di Parigi e il senso di colpa". cit., p. 43 e ss.

${ }^{192}$ Entrevista a Tabucchi, feita por Anna Botta, em Florença, em junho de 1990. Citada por Dolfi em "Lo spleen di Parigi e il senso di colpa". In: Gli oggetti e il tempo della saudade. cit., p. 43: "À ‘saudade' não é estranho o 'spleen' baudelairiano ou até um mal existencial. Indica, substancialmente, a condição de um sujeito que se encontra em uma situação de falta. Alguns dos meus personagens sofrem disso. Gosto dos personagens que são mutilados, que vivem em uma situação de privação que é para eles motivo contínuo de mal estar".
} 
Estes personagens de que fala Tabucchi podem ser encontrado não só no conto analisado, como em toda a coletânea. São presenças fugidias, personagens que se constituem como imagens desbotadas e/ou são apenas vestígios de personagens. Possuem uma subjetividade fluida, uma fisionomia lúgubre, nebulosa, e em geral se escondem sob máscaras de tristeza, de saudade.

Esses personagens predominam em narrativas fragmentárias, cheias de "buracos", dilacerações, fissuras. A suspensão do final, assim como a incerteza do epílogo, são uma escolha poética recorrente: a história permanece aberta e pode ser completada, ao menos em parte, pelo leitor, com o auxílio de outras obras e com o conhecimento das fontes, a decodificação dos sinais - tarefa de um leitor apurado, condizente com a personalidade sofisticada de seus narradores.

Quanto ao foco narrativo, ainda segundo Ceserani, é bastante particular: o narrador passa, em determinado momento, da primeira à segunda pessoa do discurso, retomando experimentos da neo-vanguarda francesa, em particular o romance de Michel Butor, A modificação, que utliliza a segunda pessoa do plural (no original em francês). O procedimento de Tabucchi, semelhante ao de Butor, procura identificar e aproximar leitor e personagem, além de se ajustar bem à tendência do "protagonista a parlare con se stesso, a guardarsi negli specchi, a dialogare con la propria anima e a tormentare la propria memoria" ${ }^{, 193}$. Esta passagem é marcada no início da narrativa (que, aliás, possui um único parágrafo), no senguinte trecho: "E anche questo mi dà il senso di una libertà bella e superflua, come quando hai pensato a lungo di fare una certa cosa e finalmente ci sei riuscito"194. Nota-se, aqui, o uso do pronome "mi”, relativo à primeira pessoa, que cede lugar à forma verbal de segunda pessoa "hai pensato". Deste ponto em diante, a narrativa assume o foco da segunda pessoa até o seu encerramento, o que inclui o leitor e o transforma no próprio sujeito da narrativa, provocando um efeito de espelhamento entre narrador e leitor.

Michel Butor, em seu ensaio "O uso dos pronomes pessoais no romance"195, considera que na narrativa romanesca existem três pessoas do verbo que se colocam em jogo: duas pessoas reais, ou seja, o autor que conta a história, correspondente ao "eu" da

\footnotetext{
${ }^{193}$ Ceserani, R. "Qualche considerazione sulla modernità liquida”. In: La modernità letteraria. cit., p. 19: "tendência do protagonista a falar consigo mesmo, a se olhar nos espelhos, a dialogar com a própria alma e a atormentar a própria memória".

${ }^{194}$ Tabucchi, A. "Any where out of the world". cit., p. 190: "E isso também me dá uma sensação de liberdade bela e supérflua, como quando você pensou em fazer uma certa coisa e finalmente conseguiu".

${ }^{195}$ Butor, M. "O uso dos pronomes pessoais no romance". In: Repertório. Trad. Leyla Perrone-Moisés. São Paulo: Perspectiva, 1974. pp. 47-57.
} 
narrativa; o leitor, a quem a história é contada, ou o "tu" a quem se dirige o autor; e uma pessoa fictícia, o herói, aquele de quem se narra a história, o "ele". Segundo Butor, o emprego da segunda pessoa do discurso na narrativa implica em "alguém a quem se conta sua própria história, algo dele que ele não conhece, ou pelo menos não ainda no

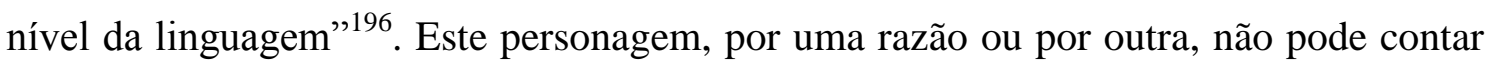
sua própria história, pois, de algum modo, a linguagem lhe foi interditada, e "é preciso

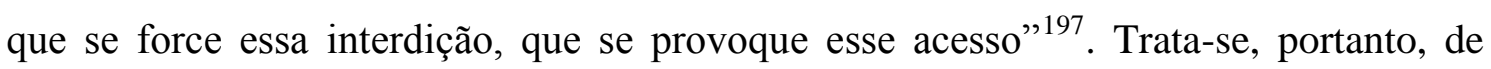
“arrancar" essa história do personagem - ou porque ele está mentindo, escondendo algo de nós ou de si mesmo, ou porque não tem acesso a todos os elementos, e se os tem, não é capaz de ligá-los de forma conveniente ${ }^{198}$.

Percebe-se que Tabucchi adota essa perspectiva em "Any where out of the world", forçando o protagonista a revelar sua história, a buscar em suas memórias mais profundas o que de alguma forma estava escondido. Para adentrar sua história, o "eu" narrativo assume um "tu" distanciado de si mesmo e, assim, consegue fazer com que esta venha à tona, aflore na consciência. O conto descreve, dessa forma, um processo de conscientização que se dá justamente por meio da linguagem, pela redescoberta do que foi suprimido pela consciência do personagem. O uso da segunda pessoa funciona, portanto, como um modo de suprir uma ausência, nesse caso específico, do próprio "eu" que, escondido nas fissuras da narrativa, deve se manifestar, tornar-se presente.

Outro tema central nesse conto e frequente na narrativa tabucchiana em geral, é o do desencontro do protagonista com uma pessoa importante de seu passado: em "Rebus", como visto, o narrador não consegue reencontrar Miriam; em "Il gatto dello Cheshire", de Il gioco del rovescio, uma mensagem na secretária telefônica marcando um encontro, faz com que o narrador se desloque no espaço e no tempo em busca de uma personagem de seu passado. O tema está presente também no romance epistolar $\mathrm{Si}$ sta facendo sempre più tardi, em que "l'appuntamento mancato" é o motor para a escrita das cartas dos amantes "fuori orario".

Nessas narrativas, o acaso é determinante para os desencontros. Assim como em "Il gatto dello Cheshire", o encontro com o passado não acontece, o personagem passa da estação, e a busca de uma resposta para a mensagem telefônica fantasmática, vinda deste passado, permanece em suspenso. Enquanto no conto de Il gioco del

\footnotetext{
${ }^{196}$ Butor, M. "O uso dos pronomes pessoais no romance”. cit., p.52.

${ }^{197}$ Butor, M. "O uso dos pronomes pessoais no romance”. cit., p. 52.

${ }^{198}$ Butor, M. "O uso dos pronomes pessoais no romance”. cit., p. 52.
} 
rovescio a mensagem chega por meio do telefone, em "Any where out of the world", a presença fantasmagórica do passado se manifesta por meio de um anúncio de jornal deslocado no tempo, com uma frase codificada que deveria ter sido publicada quatro anos antes, em uma data específica: 22 de setembro. Passados quatro anos, na mesma data emblemática o protagonista lê a misteriosa frase no jornal: tudo se repete em uma coincidência paradoxal, indecifrável. Como em "Il gatto dello Cheshire", a data - 15 de julho, às 15 horas - é simbólica e aprisiona o personagem, fazendo-o refletir sobre o tempo, que devora as coisas e depois as faz reaparecer na memória, seja na forma de uma lembrança, de um sonho, de um objeto, de um telefonema ou de um anúncio de jornal.

O narrador desliza no tempo ao passo que percorre a cidade, deslocando-se do presente narrativo ao passado recordado por meio da poesia de Baudelaire. Retoma a memória de uma história não resolvida, mas tem consciência da inexistência de uma solução possível. Como o narrador de "Rebus", este também tenta decifrar ou entender o mecanismo que determina o acaso e guia todas as coisas: "Come vanno le cose. E cosa le guida. Un niente"199. O narrador sabe que este pequeno "nada" ordena tudo no mundo, os encontros e desencontros - é a roda do destino, que distribui todos os papéis, move todas as coisas e faz com que uma história já vivida possa se repetir no tempo. A vida é aquilo que não se pode medir, simplesmente acontece, sem prazos ou datas fixadas: "la vita non si misura con un metro etico: accade"; "la vita non ha scadenze"200.

$\mathrm{Na}$ tentativa de investigar a veracidade do anúncio ou confirmar sua falta de sentido, o protagonista procura um telefone e disca o número do passado, mesmo sabendo que é um número "morto", que já não existe mais:

\footnotetext{
"Componi il numero lentamente, senti squillare una volta, due volte, tre volte, poi il ricevitore fa: crec, ma nessuna voce risponde, senti solo una presenza, non è neppure un respiro, perché non respira, dall'altra parte del filo c'è una presenza che sta lì ad ascoltare la presenza del tuo silenzio"201.
}

\footnotetext{
${ }^{199}$ Tabucchi, A. "Any where out of the world”. cit., p. 189: "Como vão as coisas. E o quê as guia. Um nada".

${ }^{200}$ Tabucchi, A. "Any where out of the world". cit., p. 196: "a vida não se mede com um metro ético: acontece"; "a vida não tem prazos".

${ }^{201}$ Tabucchi, A. "Any where out of the world". cit., p. 197: "Disca o número lentamente, ouve o toque uma vez, duas vezes, três vezes, depois o telefone faz: crec, mas nenhuma voz responde, você sente só uma presença, não é nem mesmo um respiro, porque não respira, do outro lado da linha, há uma presença que está ali, ouvindo a presença do seu silêncio".
} 
Desliga e evita voltar para casa, pois sabe que seu telefone poderia tocar, e que ele o deixaria tocar uma ou duas vezes e que, quando o atendesse, do outro lado da linha, reconheceria apenas "la densità distinguibile di una presenza che in silenzio ascolta il silenzio della tua presenza" ${ }^{, 202}$. Então, caminha de novo até o rio, e permanece ali, observando o deserto do cais, a inquietude das águas, a vastidão das horas que passam solenemente. E uma última citação de Baudelaire, desta vez do poema $O$ relógio ${ }^{203}$, conclui a narrativa: “l'ora è vasta, solenne, grande come lo spazio: un'ora immobile che non è segnata sul quadrante, e tuttavia leggera come un sospiro, rapida come un colpo d'occhio"204.

O olhar voltado para as águas que correm deixa a impressão de que "tutto scorre e niente sta fermo"205. O tempo passado e a impossibilidade de detê-lo, assim como o sentimento de culpa por uma história feita "di sotterfugi, di rimandi, e di imbrogli" 206 , são os verdadeiros temas de Tabucchi, trabalhados incessantemente nesse conto e em outros que compõem a coletânea Piccoli equivoci senza importanza. A culpa é a palavra insuportável, simples e unívoca, impronunciável, que gera fantasmas:

\footnotetext{
"La colpa. È una parola che non hai mai pronunciato, forse perché non avevi il coraggio, eppure è una parola semplice, univoca, risuona chiara nel buio e sembra entrare tutta in quel breve alone di fiato che si condensa in un attimo nell'aria e poi svanisce" 207 .
}

É a mensagem subterrânea que vêm à tona em um instante voraz, que revira tudo do avesso e depois se esvai, em um golpe de ar.

\footnotetext{
${ }^{202}$ Tabucchi, A. "Any where out of the world”. cit., p. 197: “a densidade distinguível de uma presença que, em silêncio, escuta o silêncio da sua presença".

${ }^{203}$ Baudelaire, C. "O relógio". In: O Spleen de Paris. cit., p. 53: "uma hora vasta, solene, grande como o espaço, sem repartição de minutos nem de segundos, - uma hora imóvel que os relógios não marcam e que é, no entanto, leve como um suspiro, rápida como uma olhadela".

${ }^{204}$ Tabucchi, A. "Any where out of the world". cit., p. 197: "a hora é vasta, solene, grande como o espaço: uma hora imóvel que não está marcada no quadrante do relógio e, todavia, leve como um suspiro, rápida como um piscar de olhos".

${ }^{205}$ Tabucchi, A. "Any where out of the world". cit., p. 196: "tudo passa e nada fica parado".

${ }^{206}$ Tabucchi, A. "Any where out of the world”. cit., p. 196: "de subterfúgios, de adiamentos e confusões".

${ }^{207}$ Tabucchi, A. “Any where out of the world”. cit., p. 194: “A culpa. É uma palavra que você nunca pronunciou, talvez porque não tivesse coragem e, apesar disso, é uma palavra simples, unívoca, ressoa clara na escuridão e parece caber inteira naquele breve halo de respiração que se condensa em um instante no ar e depois se esvai". Como vimos, o remorso e o sentimento de culpa perpassam várias obras do autor, é um dos temas principais de Tabucchi analisado por Anna Dolfi em Tabucchi, la specularità e il rimorso, cit., livro fundamental para compreensão desta temática na obra tabucchiana.
} 


\title{
3.4. INTERTEXTUALIDADE E AUTORREFERENCIALIDADE EM “I TRENI CHE VANNO A MADRAS"
}

\author{
“Un senso della letteratura, o uno dei suoi infiniti sensi, insomma, è fondamentalmente \\ questo: che la letteratura non è a senso unico, non è lineare e progressiva, ma funziona nei \\ due sensi: influenza il futuro ma anche il passato, è una freccia geometrica con due punte e \\ due direzioni". \\ Antonio Tabucchi.
}

Como vimos em "Any where out of the world", os personagens e narradores tabucchianos são, constantemente, profundos conhecedores de literatura. A presença e/ou a reflexão sobre a literatura é tematizada em muitas de suas narrativas, por meio de citação explícita, aludida, ou como parte da constituição do personagem, de sua formação intelectual, visto que muitos personagens de Tabucchi são também leitores.

A vasta biblioteca de Tabucchi inclui desde os clássicos aos contemporâneos, o que frequentemente dificulta a compreensão de sua obra narrativa e faz com que o leitor "real" busque na literatura os sentidos do texto. Piccoli equivoci senza importanza, assim como Il gioco del rovescio e L'Angelo Nero estão repletos de alusões, citações e homenagens a autores diversos.

O conto "I treni che vanno a Madras", por exemplo, é uma narrativa que não pode prescindir de um conhecimento extratextual: a obra de Adelbert Von Chamisso, $A$ história maravilhosa de Peter Schlemihl, publicada em 1814, referência importante que o autor dá ao leitor, e sem a qual é difícil compreender e compor a personalidade enigmática do personagem que o narrador encontra em um trem indiano. Mas Chamisso não é o único autor homenageado por esta narrativa: Tabucchi cita também o escritor alemão Thomas Mann, dá indicações precisas das obras que conhece: Tonio Kröger e Morte em Veneza, além da referência ao prefácio de Mann à obra de Chamisso, publicado em 1911, indicando ao leitor as pistas que deve seguir para interpretar o texto.

$\mathrm{O}$ conto narra o encontro de dois viajantes em um trem indiano que vai para a cidade de Madras. Durante a viagem, os dois homens conversam sobre os mistérios da 
Índia, suas religiões, sua arte e arquitetura, e também sobre literatura alemã, em particular. O narrador, em primeira pessoa, ouve de seu companheiro de viagem uma intrigante história sobre as humilhações que teria sofrido durante as visitas médicas em um campo de concentração alemão, na Segunda Guerra. E relata que o motivo para ir a Madras é o desejo de ver uma estátua, a de Shiva Dançante, que representa o ciclo da vida. Após a chegada em Madras, despedem-se e não voltam a se encontrar. No dia de sua partida, o narrador lê, em um jornal indiano, uma curiosa notícia sobre o assassinato, aparentemente sem motivos, de um senhor estrangeiro, conhecedor de arte dravídica. O narrador suspeita que o assassino, não identificado pela polícia local, possa ter sido seu companheiro de viagem, uma vez que ao lado da vítima, encontrava-se uma estátua de Shiva.

Entre as referências intertextuais que servem para compor a personalidade do viajante europeu, a mais importante, como dissemos, é a obra de Chamisso, visto que este personagem se apresenta como Peter Schlemihl. O narrador, também europeu, demonstra ter algum conhecimento sobre literatura alemã, e percebe logo que o nome adotado por seu companheiro de cabine é falso. A história fantástica do personagem que vendeu a própria sombra "preenche" os vazios de personalidade do enigmático viajante. Tabucchi procura se aproximar da atmosfera da narrativa de Chamisso, escrevendo um conto nos moldes da literatura fantástica alemã, ou pelo menos, uma paródia deste modelo. A clareza e a concisão do conto resgatam, por sua vez, a narrativa de Mann, como se houvesse uma tentativa do autor italiano de se aproximar do estilo do escritor alemão.

Peter Schlemihl é o personagem que vende sua sombra a um misterioso "homem cinzento", uma representação do diabo, em troca das riquezas que the seriam proporcionadas por uma bolsa mágica, capaz de gerar moedas de ouro. Esta troca logo se revela, porém, um problema para o personagem, pois, ao perder sua sombra, Peter perde também seu status social, e não consegue ser aceito pela sociedade.

Na sociedade burguesa do século XIX, representada na narrativa de Chamisso, a imagem social possui o mesmo prestígio que o poder econômico, visto que nesta ainda predominam os valores da nobreza e da aristocracia como centro de poder. Muitos burgueses desta época pretendiam o título de nobreza, queriam frequentar os ambientes aristocratas e fazer parte deste grupo de prestígio representado pelos nobres, condição que prevalece até o início do século XX. Sendo assim, perder a sombra, símbolo da 
aparência e do status, corresponde a perder o próprio valor social e ser excluído para sempre da possibilidade de participar desta sociedade. De acordo com Thomas Mann, no prefácio citado pelo narrador do conto tabucchiano,

\footnotetext{
“a sombra transformou-se no 'Peter Schlemihl' em símbolo de solidez burguesa e agregação humana. Ela é mencionada ao lado do dinheiro, como algo a ser respeitado caso se queira viver entre os homens e do qual só se pode desprender aquele que esteja disposto a viver exclusivamente para si e para o que há de melhor em seu interior" ${ }^{208}$.
}

Ainda de acordo com Mann, Chamisso consegue "dignificar de forma dolorosa o valor de uma sombra saudável" ${ }^{209}$, ao fazer com que seu personagem não ceda às tentações do diabo e se reconcilie consigo e com o mundo por meio do retorno à natureza. Peter se torna, então, um naturalista, abdica da vida social e passa seus dias a viajar em prol de descobertas científicas.

Assim como o personagem de Chamisso, o viajante de Tabucchi também é um homem que perdeu a sombra, um excluído do sistema social, que passa seus dias tentando se vingar do médico nazista que o humilhara e se apropriara de sua dignidade no passado:

\footnotetext{
“"Come vede non sono ancora entrato nel circolo del riciclaggio vitale, e la mia interpretazione di quella figura è un'altra. Ci ho pensato ogni giorno, è l'unica cosa a cui ho pensato in tutti questi anni'.

'Quanti anni sono passati?'

'Quaranta'.

'Si può pensare a una sola cosa per quarant'anni?'.

'Credo di sì, se si è provata su di noi la turpitudine',210.
}

Para recompor sua vida, reconciliar-se com o mundo, o viajante deve encontrar sua "sombra", mostrando ao homem que o humilhara o verdadeiro significado da

\footnotetext{
${ }^{208}$ Mann, Thomas. "Chamisso". In: Chamisso, A. A história maravilhosa de Peter Schlemihl. Trad. Marcus Vinicius Mazzari. São Paulo: Estação Liberdade, 1989, p. 110.

${ }^{209}$ Mann, Thomas. "Chamisso". cit., p. 110.

${ }^{210}$ Tabucchi, A. "I treni che vanno a Madras". In: Racconti, cit., p. 232: "Como vê ainda não entrei no círculo da reciclagem vital, e a minha interpretação daquela figura é outra. Pensei nisso todo dia, é a única coisa em que pensei em todos estes anos'. 'Quantos anos se passaram?'. 'Quarenta'. 'Pode-se pensar em uma coisa só por quarenta anos?'. 'Acredito que sim, se se instalou sobre nós a torpeza'.’
} 
estátua de Shiva Dançante. Para ele, este significado não está ligado ao ciclo da vida, à evolução que prevê que cada ser, alcance, a cada vida vivida, um degrau superior, como afirmava o médico alemão, mas representava, simplesmente, a dança da vida: "La vita è un cerchio. C'è un giorno in cui il cerchio si chiude, e noi non sappiamo quale",211.

E, aparentemente, o misterioso assassinato ao final do conto pode significar que o viajante tenha alcançado o seu objetivo e que o círculo vital do médico tenha se encerrado. Esta hipótese, entretanto, permanece em aberto: a narrativa deixa como pista ao narrador e, consequentemente, ao leitor, a aproximação entre uma estatueta de Shiva encontrada ao lado da vítima e a informação de que o homem estrangeiro assassinado era um conhecedor de arte dravídica.

Além da referência a Chamisso, outro texto importante, que aparece citado em "I treni che vanno a Madras" é um guia de viagem sobre a Índia, chamado India, a travel survival kit, publicado pela Lonely Planet Publications que, de acordo com o narrador, procura dar ao viajante um suporte diferenciado em relação aos roteiros turísticos tradicionais. Este guia, também citado em vários trechos de Notturno indiano, parece indicar que o narrador do Notturno teria feito a mesma viagem que o narrador do conto de Piccoli equivoci senza importanza, o que nos faz pensar que o conto poderia ser um capítulo não aproveitado pelo romance, utilizado por Tabucchi como texto autônomo.

Tematicamente, ambos os textos apresentam personagens que procuram por alguém que se "perdeu" na misteriosa Índia, um "outro" imprescindível, que se configura como uma espécie de fantasma ou "sombra". Além disso, as datas de publicações dos dois livros, Notturno indiano, em 1984, e Piccoli equivoci, em 1985, mostram a proximidade temporal em que foram escritas as duas narrativas. E, de fato, segundo Anna Dolfi, "I treni che vanno a Madras" foi concebido, originalmente, como parte do Notturno indiano, mas devido ao seu tom menos vago e impreciso, que diferia um pouco da atmosfera do romance, foi deslocado e isolado como conto ${ }^{212}$.

De qualquer modo, é a referência ao guia que traz para a narrativa o outro texto tabucchiano, em uma operação intertextual e autorreferencial que estabelece, de certo modo, um movimento dialógico, um jogo de espelhos ou uma sobreposição de camadas

\footnotetext{
${ }^{211}$ Tabucchi, A. "I treni che vanno a Madras". cit., p. 233: "A vida é um círculo. Um dia o círculo se fecha, e nós não sabemos qual".

${ }^{212}$ Dolfi, A. Antonio Tabucchi, la specularità, il rimorso. cit., p. 42.
} 
narrativas no texto. Essa autorreferencialidade, procedimento comum à obra de Tabucchi, assinala um desdobramento do autor, que remete, no texto, à sua própria obra.

Como assinala Michael Rifaterre, em seu ensaio "A ilusão referencial”, o texto poético, porque autônomo, não faz referências externas ao real, mas somente a outros textos; é autorreferencial porque sua unidade de significação está situada em si mesmo $^{213}$. Segundo o autor,

\footnotetext{
"a existência de uma realidade não verbal fora do universo das palavras é inegável, todavia, a crença ingênua num contato ou relação direta entre palavras e referentes é uma ilusão" ${ }^{214}$.
}

Realidade, neste contexto, quer dizer "representação literária da realidade", ou seja, a mimese, que não é mais que "o pano de fundo que torna perceptível o caráter indireto da significação",215.

Também Italo Calvino, em seu ensaio "I livelli della realtà in letteratura"216, considera que existem vários pontos de contato entre o "real" (referencial) e a representação deste real no contexto da literatura. Todavia, ressalta que a literatura não conhece "a realidade", mas somente "níveis de realidade", nada mais que aspectos parciais desta realidade:

\footnotetext{
"Se existe $a$ realidade da qual os vários níveis nada mais são que aspectos parciais, ou se só os níveis existem, é algo que a literatura não pode decidir. A literatura conhece a realidade dos níveis e essa é uma realidade que ela conhece melhor, talvez, do que já se chegou a conhecer por meio de outros procedimentos cognitivos" 217 .
}

Para Calvino, a obra literária é composta de uma sobreposição de níveis de realidade que adentram uns nos outros se confundindo e se misturando até se

\footnotetext{
${ }^{213}$ Rifaterre, "A ilusão referencial”. in: Literatura e realidade (que é o realismo?). Lisboa: Publicações Dom Quixote, 1984. p. 102.

${ }^{214}$ Rifaterre, “A ilusão referencial”. cit., p. 100.

${ }^{215}$ Rifaterre, “A ilusão referencial”. cit., p. 99.

${ }^{216}$ Calvino, Italo. "I livelli della realtà in letteratura". In: Una pietra sopra. Discorsi di letteratura e società. Turim: Einaudi, 1980. pp. 310 a 323.

${ }^{217}$ Calvino, I. "Os níveis da realidade em literatura". In: Assunto encerrado. Discursos sobre literatura e sociedade. Trad. Roberta Barni. São Paulo: Companhia das Letras, 2006. p. 384.
} 
harmonizarem em um todo que não é outra coisa senão um jogo de espelhos, reflexos inconciliáveis e, ao mesmo tempo, indissociáveis. A literatura é regida por esta distinção de níveis de realidade, sem a qual seria impensável. E esta distinção de níveis que se fundem ou se refletem uns nos outros consiste na própria função da literatura: aquela de espelho mágico ${ }^{218}$.

Em "I treni che vanno a Madras", Tabucchi procura fazer com que sua arte se englobe a si mesma, criando um jogo de espelhos, uma mise em abyme, um diálogo entre as duas narrativas, seja pela natureza e intuito da escrita dos dois textos, seja pela temática que abordam, sobretudo se considerarmos que, no breve prefácio de Notturno indiano, o autor declara:

\begin{abstract}
"Questo libro, oltre che un'insonnia, è un viaggio. L'insonnia appartiene a chi ha scritto il libro, il viaggio a chi lo fece. Tuttavia, dato che anche a me è capitato di percorrere gli stessi luoghi che il protagonista di questa vicenda ha percorso, mi è parso opportuno fornire di essi un breve indice. Non so bene se a ciò ha contribuito l'illusione che un repertorio topografico, con la forza che il reale possiede, potesse dare luce a questo Notturno in cui si cerca un'Ombra; oppure l'irragionevole congettura che un qualche amante di percorsi incongrui potesse un giorno utilizzarlo come guida"219.
\end{abstract}

Como se pode ver nesta nota, tanto o conto quanto o romance tabucchiano tratam de personagens que viajam em busca da própria sombra - ou da alma. Com sua estrutura concisa, o conto reflete toda a narrativa do Notturno indiano, podendo ser utilizado como um guia de leitura para o romance. O conto contém ao mesmo tempo em que é contido pelo romance, em um processo de intertextualidade autorreferencial, que consiste em um modo de fazer poético característico da literatura tabucchiana.

\footnotetext{
${ }^{218}$ Calvino, I. "Os níveis da realidade em literatura". In: Assunto encerrado. cit., p. 382: "O que cantam as sereias? Uma hipótese possível é que o canto delas nada mais seja que a Odisseia. A tentação do poema de englobar a si mesmo, de refletir-se como num espelho, aparece várias vezes na Odisseia, especialmente nos banquetes em que os aedos cantam. E quem melhor que as Sereias poderia dar ao próprio canto essa função de espelho mágico?".

${ }^{219}$ Tabucchi, A. Nota a Notturno indiano. In: Noturno indiano. cit., p. 9. "Este livro, mais que uma insônia, é uma viagem. A insônia pertence a quem escreveu o livro, a viagem a quem a fez. Todavia, dado que a mim também ocorreu de percorrer os mesmos lugares que o protagonista desta trama percorreu, pareceu-me oportuno fornecer um breve índice destes. Não sei bem se a isto contribuiu a ilusão de que um repertório, com a força que o real possui, pudesse dar luz a este Noturno em que se procura uma Sombra; ou então a irracional conjectura que um amante qualquer de percursos incongruentes pudesse, um dia, utilizá-lo como guia".
} 
O prefácio ou a nota introdutória atua aqui como uma declaração de poética, mais que como uma simples explicação sobre o livro. A primeira nota tabucchiana a desempenhar a função de indício precioso para o leitor, que passa, por sua vez, à condição de investigador, é justamente a nota ao Notturno indiano, embora já em Donna di Porto Pim, publicado em 1983 - antes, portanto, do Notturno - o autor apresente um prólogo que reflete sobre o livro de viagens. A partir de então, todos os seus livros contém prefácios ou notas introdutórias que são essenciais para a compreensão de suas narrativas e histórias, tornando-se, além disso, uma marca do estilo do autor.

Em sua nota à Piccoli equivoci senza importanza, por exemplo, o autor esclarece que a coletânea procura demonstrar como a ficção, em alguns casos, pode parecer mais verossímil que o próprio real. Isso se dá, sobretudo, por meio da inserção da ideia de "equívoco" como chave interpretativa de seus contos. Como recurso estilístico, inspirado na arte barroca, o equívoco consiste em um mal-entendido linguístico, uma imprecisão, um engano que estabelece a ambiguidade no discurso literário, recurso de que se utiliza o escritor para criar seus jogos narrativos, para compor a vida desencontrada de seus personagens. Como chave de leitura, a nota antecipa uma ideia, um modo de ver a literatura e de fazer com que o leitor reflita sobre o processo de escrita do autor.

Devemos ressaltar, todavia, que os prefácios e notas nem sempre correspondem a uma "realidade". Muitas vezes são parte do jogo ficcional tabucchiano, que dá pistas falsas sobre o significado de sua escrita, confundindo o leitor. Basta recordar, por exemplo, a (falsa?) correspondência entre um "leitor" de Notturno Indiano e o autor, na narrativa "La frase che segue è falsa. La frase che precede è vera", publicada na coletânea I volatili del Beato Angelico, em que o autor afirma que "os escritores mentem":

\footnotetext{
"Non creda troppo a ciò che affermano gli scrittori: essi mentono (dire menzogne) quasi sempre. (...) Ciò che lo scrittore esibisce di se stesso non sono le sue segrete grazie (...) ma i fantasmi che lo assediano, la parte più brutta di se stesso: le sue nostalgie, le sue colpe e i suoi rancori, ${ }^{220}$.
}

\footnotetext{
${ }^{220}$ Tabucchi, A. "La frase che segue è falsa. La frase che precede è vera". In: I volatili del Beato Angelico. cit., p.53. Trad. Bras. “A frase a seguir é falsa. A frase anterior é verdadeira”. In: Os voláteis do Beato Angélico. cit., p. 59: "Não acredite muito no que afirmam os escritores: eles mentem (dizem falsidades)
} 
Assim, podemos considerar que o prefácio é uma declaração de poética, um indício de leitura e um procedimento estilístico característico da ficção tabucchiana.

quase sempre. (...) $\mathrm{O}$ que o escritor mostra de si mesmo não são as suas secretas graças (...) mas os fantasmas que o perseguem, a parte mais feia de si mesmo: as suas nostalgias, as suas culpas e os seus rancores". 


\section{L'ANGELO NERO E A FICCIONALIZAÇÃO DA HISTÓRIA}

\subsection{DIÁLOGO ENTRE LITERATURA E HISTÓRIA.}

“O retorno do passado nem sempre é um momento libertador da lembrança, mas um advento, uma captura do presente".

Beatriz Sarlo.

L'Angelo Nero, publicado em 1991, é uma coletânea de contos que possuem, segundo o próprio autor, um tema único e um fio condutor que une todas as histórias: a "presença maléfica de um anjo negro". De acordo com Anna Dolfi, esta presença maléfica ou "inquietante estraneità" - inquietante estranheza - é um dos elementos comuns aos seis contos presentes na coletânea, que por meio dos lugares, dos personagens, dos objetos criados pela escrita, parecem alterar a consistência das coisas, a imagem delas, levar o personagem a se olhar surpreso, sem se reconhecer, imerso em um mundo povoado de sinais inquietantes ${ }^{221}$.

Existe também, neste volume, uma problematização da experiência histórica contemporânea por meio da expressão literária, ou seja, Tabucchi conjuga o binômio História e Literatura, voltando seu olhar para a condição do homem contemporâneo, sem perder de vista, entretanto, a formalização estética da matéria narrativa e as especificidades do gênero literário.

O final dos anos de 1960 e seus acontecimentos tumultuosos na Europa constituem não só a ambientação temporal e o pano de fundo de alguns dos contos, como também entrelaçam tematicamente algumas das narrativas. Em alguns dos contos,

${ }^{221}$ Dolfi, A. "L'Angelo Nero e gli animali inquietanti". In: Tabucchi, la specularità, il rimorso. cit., p. 214. 
traumas individuais são colocados em relação direta com momentos dramáticos da história italiana, tais como o fascismo e o terrorismo dos anos de 1970, discutindo os limites do estético na representação e na crítica do real histórico e social ${ }^{222}$.

A problemática da representação da história é uma constante na obra de Tabucchi desde a publicação de Piazza d'Italia que, como vimos, focaliza a questão histórica a partir de uma tentativa de descrever a história da perspectiva dos perdedores, nos termos benjaminianos, seria uma tentativa de escrever a história a "contrapelo", inserindo o autor numa tradição narrativa que inclui autores como Giovanni Verga, Inazio Silone, Beppe Fenoglio, Leonardo Sciascia, dentre outros.

Segundo Brizio-Skov, quase toda a produção literária de Tabucchi gira em torno destas duas constantes fundamentais: História e Literatura. A reescrita da história advém por meio de textos literários que tentam "fazer História", ou seja, textos que revelam como as coisas realmente aconteceram, textos que falam da história italiana do último século vista de uma perspectiva "rovesciata" - invertida - aquela dos rebeldes, dos perseguidos, dos perdedores que observam de "baixo" a realidade que os rodeia e se chocam tragicamente com a perspectiva "alta" daqueles que detém o poder. Textos literários que revelam aquilo que a história silenciou, e que ousam revelar os enigmas da História, ou seja, as razões que se escondem atrás de muitos eventos da vida política italiana deste século. Textos como Sostiene Pereira que falam de 1938 e da ditadura de Salazar, mas que na realidade falam da crise do intelectual de hoje, da indecisão do homem de cultura preso na armadilha "velhos valores x fim das grandes ideologias"; textos que narram sobre como a Literatura está relacionada com a História e como a História está ligada à Literatura ${ }^{223}$.

Linda Hutcheon, em seu estudo sobre a Poética do Pós-Modernismo, afirma que a arte pós-moderna contesta a separação entre Literatura e História proposta pelo cientificismo do século XX. Diz a autora que os dois gêneros sempre foram permeáveis e que a teoria e a arte pós-modernas têm se concentrado mais em suas semelhanças do que em suas diferenças. Hutcheon nota que história e ficção têm em comum a seleção, a organização, a diegese, a anedota, o ritmo temporal e a elaboração da trama, mas que não fazem parte da mesma ordem de discurso. São diferentes embora possuam os

\footnotetext{
${ }^{222}$ Francese, J. Apud Jansen, M. Il dibattito sul postmoderno in Italia. cit., p. 299.

${ }^{223}$ Brizio-Skov, "Dai racconti a Notturno Indiano: 'gioco del rovescio', rebus, equivoci, mistero, intertestualità e percorsi incongrui”. In: Antonio Tabucchi: navigazioni in un arcipelago narrativo. cit., p. 17.
} 
mesmos contextos sociais, culturais e ideológicos, além das mesmas técnicas formais. As duas formas são sistemas de significação em nossa cultura e a ficção tende a incorporar a história social e política até certo ponto. Tanto historiadores como romancistas constituem seus sujeitos como possíveis objetos de representação narrativa e o fazem por meio das próprias estruturas e da própria linguagem ${ }^{224}$.

Em algumas das narrativas de L'Angelo Nero, como veremos a seguir, a ficção cede espaço à citação, à acumulação e repetição de imagens e textos já existentes. Tabucchi utiliza o processo da colagem de trechos, seja de obras literárias, poemas, seja de trechos da história recente - os totalitarismos e as guerras do século $\mathrm{XX}$, os anos de Chumbo na Itália - combinando-os em textos fragmentados, em que predomina a instabilidade da linguagem e do discurso. A experiência do narrador se reduz, nessas narrativas, a uma colagem de fragmentos descontínuos, a uma mistura de sonho e delírio, a um mosaico de citações, em que cada elemento citado quebra a continuidade ou a linearidade do discurso.

Esse processo de colagem/montagem do texto literário é visto por alguns críticos, estudiosos e filósofos, tais como Derrida, como a modalidade primária do discurso pós-moderno, que considera que a heterogeneidade inerente a este processo nos estimula, enquanto receptores do texto, a "produzir uma significação que não poderia ser unívoca nem estável"225. O escritor criaria então "matérias-primas", fragmentos e elementos, deixando aberta aos receptores a recombinação destes elementos da maneira que eles quiserem, ou, a partir das referências que eles tiverem. $\mathrm{O}$ efeito almejado seria o de quebrar ou "descontruir" o poder do autor de impor significados ou de oferecer uma narrativa contínua. Em todo caso, a descontinuidade do discurso e o conseguinte colapso na cadeia significativa seriam modos de leitura da pós-modernidade, modos de pensar sobre textos e de ler textos. O escritor pós-moderno questiona, assim, todas as ilusões de sistemas fixos de representação ${ }^{226}$.

A narrativa passa, dessa forma, por um processo de construção que se dá por meio da acumulação de referências históricas que o leitor não ingênuo, deve possuir para decodificar e compreender o texto. A acumulação como processo de estruturação do texto literário pressupõe um tipo de experiência narrativa em que tudo é precário,

\footnotetext{
${ }^{224}$ Hutcheon, L. Poética do Pós-Modernismo. cit., pp. 141 e ss.

${ }^{225}$ Derrida apud Harvey, D. Condição pós-moderna: uma pesquisa sobre as origens da mudança cultural. Trad. Adail U. Sobral e Maria Stela Gonçalves. São Paulo: Ed. Loyola, 1992. p. 53.

${ }^{226}$ Harvey, D. Condição pós-moderna: uma pesquisa sobre as origens da mudança cultural. cit., p. 53-55.
} 
provisório e fluido, em que a experiência só se constitui como vestígio e o narrador não se estabiliza em uma subjetividade, é, antes, problematizado em sua formalização ${ }^{227}$.

Essas considerações sobre a escrita e os modos de leitura na contemporaneidade nos servem de base para a reflexão sobre as narrativas de L'Angelo Nero, já que nestes contos, Tabucchi lida com a complexidade da realidade factual que interfere na sua escrita mas, como considera o próprio autor, de maneira refletida, matizada, servindo como matéria para a invenção. E para tratar de uma "matéria fluida", de uma experiência histórica problemática que não pode ser apreendida em todas as suas dimensões, Tabucchi busca, de certo modo, uma formalização estética que consiga descrever a realidade representada, sem tentar, todavia, "dar conta" desta realidade, pois "il poeta, il narratore, il pittore non deve dar conto di nulla e a nessuno se non a un'idea di linguaggio che si propone come il luogo di ogni invenzione e scoperta",228.

\footnotetext{
${ }^{227}$ Hossne, A. Saad. "Degradação e acumulação: considerações sobre algumas obras de Luiz Ruffato". In: Harrison, M. I. (Org.) Uma cidade em camadas: ensaios sobre o romance Eles eram muitos cavalos de Luiz Ruffato. Editora Horizonte, 2007.

${ }^{228}$ Guglielmi apud Jansen. Il dibattito sul postmoderno in Italia. cit., p. 236 (nota). "o poeta, o narrador, o pintor não devem prestar contas de nada e a ninguém, a não ser a uma ideia de linguagem que se propõe como o lugar de invenção e descoberta".
} 


\subsection{OS ANOS DE CHUMBO NA ITÁLIA E AS IMPLICAÇÕES IDEOLÓGICAS DO ATO DE ESCREVER SOBRE A HISTÓRIA}

“Per arrivare alla verità bisogna sempre stravolgere l'opinione di un'opinione”.

Antonio Tabucchi.

L'Angelo Nero, segundo Tabucchi, diferencia-se muito de seus outros livros anteriormente publicados por possuir uma visão pessimista da realidade. É um livro em que se discutem as várias formas de materialização do Mal no homem e isso se dá por meio da discussão de questões históricas que são importantes para o autor, entre elas a temática do terrorismo nos anos de 1970 na Itália:

"Per uno scrittore della mia generazione, passato attraverso la visione, la constatazione di quello che stava succedendo nel nostro paese negli anni del terrorismo, certi segni degli avvenimenti che stavamo vivendo sono rimasti. Io non ho mai preso di petto il problema del terrorismo, anche perché credo che pur riuscendo a riflettere sulla storia non riuscirei a fare cronaca ed ho sempre temuto che affrontando il problema in una maniera diretta potessi fare una letteratura sostanzialmente cronachista che non mi piace. Naturalmente, questi temi affiorano nella mia narrativa, perché non si può mai chiudere gli occhi di fronte a quello che sta succedendo. Oltre tutto io sono, come tutti noi, una persona che legge i giornali, che vede la televisione e fa una constatazione del nostro presente. Dunque questi avvenimenti, in qualche modo, si possono riflettere nella mia scrittura, ma mai entrarci in maniera diretta" 229 .

\footnotetext{
${ }^{229}$ Entrevista a Antonio Tabucchi, org. Marcello Cella e Elena Pinori. In: http://www.alleo.it/content-97. Acesso em 21/06/11. "Para um escritor da minha geração, que passou pela visão, pela constatação daquilo que estava acontecendo em nosso país nos anos do terrorismo, certas marcas dos acontecimentos que estávamos vivendo permaneceram. Nunca encarei de frente o problema do terrorismo, até porque acredito que mesmo conseguindo refletir sobre a história, não conseguiria fazer um relato linear e sempre tive medo de que, enfrentando o problema de maneira direta, pudesse fazer uma literatura substancialmente jornalística, o que não me interessa. Naturalmente, estes temas afloram na minha narrativa, porque nunca se pode fechar os olhos diante do que está acontecendo. Além disso tudo, eu sou, como todos nós, uma pessoa que lê os jornais, que vê televisão e faz uma constatação do nosso presente. Portanto, esses acontecimentos, de alguma forma, podem se refletir na minha escrita, mas nunca entrar nela de maneira direta".
} 
Como podemos perceber pela entrevista, Tabucchi acredita que, para um escritor da sua geração, é difícil fugir da discussão da problemática da experiência histórica contemporânea, nesse caso específico, dos anos de terrorismo que marcam o começo dos anos de 1970 na Itália, dos sinais que estes anos deixaram impressos na memória coletiva. A sua posição, entretanto, é aquela de refletir sobre a história, de dar uma forma estética à sua matéria e não de fazer crônica.

Sendo um escritor que se propõe a aprofundar a reflexão sobre o seu tempo histórico, como afirma na entrevista acima e como bem o faz em seu livro La Gastrite di Platone, Tabucchi acredita que o intelectual e, por extensão, o escritor, possui uma função na sociedade contemporânea, uma "função interrogativa"230: isto é, aquela de colocar dúvidas e estimular a reflexão, e não confortar ou oferecer respostas fáceis “credo che l'ipotetica funzione dell'intellettuale non sia tanto 'creare' delle crisi, ma mettere in crisi" 231 . Na esteira de Maurice Blanchot, Tabucchi afirma que todo "atto di conoscenza intellettuale è anche un atto creativo" 232 .

Em La Gastrite di Platone, Tabucchi cita ainda Pier Paolo Pasolini, que em um polêmico texto de 1974, Io so, declara "saber tudo sobre os mistérios da Itália", sobre os atentados terroristas praticados no começo dos anos de 1970. Assim como Pasolini, Tabucchi acredita que esse "saber tudo" é um saber intuitivo e faz parte realmente do trabalho e do instinto do trabalho do intelectual:

\footnotetext{
Io so perché sono un intellettuale, uno scrittore, che cerca di seguire tutto ciò che succede, di conoscere tutto ciò che se ne scrive, di immaginare tutto ciò che non si sa o che si tace; che coordina fatti anche lontani, che mette insieme i pezzi disorganizzati e frammentari di un intero coerente quadro politico, che ristabilisce la logica là dove sembrano regnare l'arbitrarietà, la follia e il mistero. /Tutto ciò fa parte del mio mestiere e dell'istinto del mio mestiere. Credo che sia difficile che il mio "progetto di romanzo", sia sbagliato, che non abbia cioè attinenza con la realtà, e che i suoi riferimenti a fatti e persone reali siano inesatti. Credo inoltre che molti altri intellettuali e romanzieri sappiano ciò che so io in quanto intellettuale e romanziere" ${ }^{233}$.
}

\footnotetext{
${ }^{230}$ Tabucchi, A. La gastrite di Platone. Palermo: Sellerio Editore, 1998. p. 39

${ }^{231}$ Tabucchi, A. La gastrite di Platone. cit., p. 32. "accredito que a hipotética função do intelectual não seja tanto 'criar' as crises, mas colocar em crise".

${ }^{232}$ Tabucchi, A. La gastrite di Platone. cit., p. 36: "ato de conhecimento intelectual é também um ato criativo".

${ }^{233}$ Pasolini, Pier Paolo. "Il romanzo delle stragi”. Saggi sulla politica e sulla società. Org. Walter Siti e Silvia De Laude. Milão: Arnoldo Mondadori, 1999. pp. 362-367. Publicado originalmene no Corriere
} 
Com esta afirmação sobre a natureza instintiva do trabalho do escritor, Pasolini figura como o exemplo mais significativo para ilustrar a "função interrogativa" do intelectual/escritor a que se refere Tabucchi, e esta consiste justamente em "leggere la realtà 'al rovescio', scambiando l'asse causa-effetto",234.

Este ato de conhecimento e este modo de ler a realidade ao contrário se transformam em criatividade e servem para a escrita do conto "Il battere d'ali di una farfalla a New York può provocare un tifone a Pechino?". Este, por sua vez, estabelece um interessante diálogo com um evento polêmico da história italiana contemporânea: o caso Adriano Sofri. O conto traz para a ficção um dado histórico real, o testemunho de um ex-militante da facção revolucionária italiana Lotta Continua, Leonardo Marino, contra o jornalista e político Adriano Sofri, ex-líder desta facção - um "pentito" (arrependido) que teve uma parte muito importante como testemunha no caso Sofri. O ex-militante arrependido atribui a Sofri a responsabilidade moral pelo ato terrorista que resultou na morte de um comissário da polícia italiana, o comissário Luigi Calabresi. Calabresi tinha sido acusado por Sofri de ser o responsável pela morte do anarquista Giuseppe Pinelli, precipitado de uma janela da Delegacia de Milão durante um interrogatório sobre o ato terrorista que ficou conhecido como Atentado de Piazza Fontana, em 1969, que resultou na morte de vários civis ${ }^{235}$.

Publicado às vésperas do julgamento de Sofri, o conto de Tabucchi foi citado por um dos juízes no processo de apelação de 1991, que incluiu a narrativa (assim como também um texto de Leonardo Sciascia) nos autos do processo, pois ela teria sido concebida com a intenção de "influenciar o sucesso do processo". Tabucchi narra o fato em L'oca al passo:

della Sera, de 14/11/1974, com o título "Che cos'è questo golpe?". "Eu sei porque sou um intelectual, um escritor, que tenta seguir tudo que acontece, conhecer tudo que se escreve sobre isso, imaginar tudo que não se sabe ou que se cala, que coordena fatos mesmo distantes, que coloca lado a lado os pedaços desorganizados e fragmentários de um quadro político inteiro e coerente, que reestabelece a lógica lá onde parece reinar a arbitrariedade, a loucura e o mistério. Tudo isso faz parte do meu trabalho e do instinto do meu trabalho. Acredito que seja difícil que o meu 'projeto de romance' esteja errado, isto é, que não esteja de acordo com a realidade, e que as suas referências a fatos e pessoas reais sejam inexatas. Acredito, além disso, que muitos outros intelectuais e romancistas saibam aquilo que eu sei enquanto intelectual e romancista".

${ }^{234}$ Tabucchi, A. La gastrite di Platone. cit., p. 36: "ler a realidade 'ao contrário', invertendo o eixo causaefeito".

${ }^{235}$ Este atentado serve como argumento para a peça teatral de Dario Fo, Morte accidentale di um anarchico (Morte acidental de um anarquista), o que mostra a preocupação dos intelectuais e escritores italianos contemporâneos com os eventos históricos do período em questão. 
"Era il 1989, mi pare, era appena cominciata la sua odissea e io avevo letto sul giornale di un signore che vende frittelle il quale, vent'anni dopo, inchiodava tre persone con la 'spontanea' testimonianza resa a un sacerdote, prima di essere resa ai carabinieri e credibile perché 'aveva studiato dai salesiani' (sic, dagli atti del processo). L'incerta testimonianza mi suggerì allora un racconto intitolato Il battere d'ali di una farfalla a New York può provocare un tifone a Pechino? (...) Il mio racconto uscì nel 1990, in un volume intitolato L'Angelo Nero e fu subito oggetto di un'occhiuta magistrata, Laura Bertolé Viale, che lo inserì nella sentenza del primo processo d'appello, del 1991, in compagnia di un libro di Leonardo Sciascia, come opera atta a influenzare l'esito del processo",236.

Tabucchi nega a acusação reivindicando a autonomia de seu personagem e protesta contra a consideração da juíza dizendo que:

\begin{abstract}
"Se lei in quel poveraccio di personaggio letterario la cui falsa e contradditoria confessione fatta partorire da un maieuta di servizio, tipo il grande inquisitore o l'accusatore politico dei processi staliniani, vedeva Leonardo Marino, io revindicavo il fatto che quello era il mio personaggio, che da Marino traeva sì ispirazione, ma che era assolutamente autonomo, inventato e elaborato dalla mia fantasia. Oggi, dopo dodici anni e tanti processi subiti da Sofri e compagni, devo ricredermi. La magistrata aveva ragione in anticipo: quel personaggio è davvero Leonardo Marino. Nel senso che dai processi che sono seguiti, Marino ha fatto di tutto per assomigliare al mio personaggio. È diventato il mio personaggio. Mi ha copiato"237.
\end{abstract}

\footnotetext{
${ }^{236}$ Tabucchi, A. L'oca al passo. Notizie dal buio che stiamo attraversando. Org. Simone Verde. Milão: Feltrinelli, 2006, p. 141: "Era 1989, acho, tinha acabado de começar a sua odisseia e eu tinha lido nos jornais sobre um senhor que vende frittelle, o qual, vinte anos depois, incriminava três pessoas com o seu 'espontâneo' testemunho dado a um sacerdote, antes de ser declarado aos policiais e, acreditável porque 'tinha estudado com os salesianos' (sic, dos autos do processo). O duvidoso testemunho do vendedor de frittelle, retirado da imprensa italiana, sugeriu-me um conto intitulado: O bater de asas de uma borboleta em nova York pode provocar um tufão em Pequim? (...). O meu conto saiu em 1990, em um volume intitulado Anjo Negro e logo foi objeto de uma arguta magistrada, Laura Bertolé Viale, que o inseriu na sentença do primeiro processo de apelação, de 1991, juntamente com um livro de Leonardo Sciascia, como obra capaz de influenciar o resultado do processo".

${ }^{237}$ Tabucchi, A. L'oca al passo, cit, p. 141: "Se ela, naquele pobre personagem literário, cuja falsa e contraditória confissão, feita parir por um obstetra de plantão, como o grande inquisidor ou o acusador político dos processos de Stálin, via Leonardo Marino, eu reivindicava o fato que aquele era o meu personagem, que era inspirado sim em Marino, mas que era absolutamente autônomo, inventado e elaborado pela minha fantasia. Hoje, após doze anos e tantos processos sofridos por Sofri e companheiros, devo mudar de opinião. A magistrada tinha razão por antecipação: aquele personagem é, de fato, Leonardo Marino. No sentido que, dos processos que se seguiram, Marino fez de tudo para se assemelhar ao meu personagem. Tornou-se o meu personagem. Copiou-me”.
} 
Ao reivindicar a autonomia de seu personagem, Tabucchi retoma a tese sobre a autonomia da literatura defendida por muitos autores, em particular, por Giorgio Manganelli que afirma, em La letteratura come menzogna, um breve ensaio de 1967, que a literatura é "menzogna”, "artificio", "assenza di sincerità": "l’opera letteraria è un artificio, un artefatto di incerta e ironicamente fatale destinazione" 238 que, com as suas posições, muitas vezes desprovidas de sentido e afirmações "não verificáveis", inventa universos, ordenados de acordo com um catálogo de desenhos, sinais e esquemas, e assim nos provoca e desafia ${ }^{239}$.

Assim, a ficção tabucchiana, criada a partir de um dado da realidade, mostra um interrogatório de um misterioso funcionário da polícia feito a um igualmente misterioso senhor não nomeado, identificado pelo policial como o senhor "Farfalla". Este misterioso policial tenta convencer o depoente a narrar um homicídio político que não cometeu, mas que no passado, poderia ter cometido, quando "ainda não havia acumulado tanto rancor em relação aos seus chefes políticos", ou seja: o interrogado deveria testemunhar contra dois antigos companheiros de uma facção revolucionária, incriminando-os por um ato terrorista que poderiam ter cometido num passado recente.

$\mathrm{O}$ argumento tratado pelo autor no conto advém, portanto, de um fato da realidade histórica e de sua observação/reflexão sobre esta realidade. Por meio da narrativa, temse uma atualização do passado recente da história italiana, sua reescrita ou reapresentação de forma criativa, revelando-o ao presente e impedindo sua conclusão ${ }^{240}$.

O diálogo entre os dois personagens nos é dado por um narrador em terceira pessoa que, todavia, não se constitui como um observador direto da realidade narrada. A sua presença é reduzida a poucos verbos declarativos, que antecedem a fala dos personagens, dando apenas indicações das falas ora de um, ora de outro e distanciandose, deste modo, dos eventos enunciados. O narrador, aparentemente, não assume nenhuma responsabilidade diante do "testemunho" do depoente, tanto quanto não compactua com o interrogatório do policial, e delega, assim, a responsabilidade dos fatos narrados aos protagonistas, que são responsáveis pela veracidade ou não destes fatos. A conversa entre o policial, descrito como "o senhor vestido de azul", e o

\footnotetext{
${ }^{238}$ Manganelli, G. La letteratura come menzogna. Milão: Adelphi Edizioni, 1985. p. 222: "mentira”, "artifício", "ausência de sinceridade"; "a obra literária é um artifício, um artefato de incerta e, ironicamente, fatal destinação".

${ }^{239}$ Manganelli, G. La letteratura come menzogna. cit., p. 223.

${ }^{240}$ Hutcheon, L. Poética do Pós-Modernismo. cit., p. 147.
} 
depoente, "o homem de cabelos grisalhos", recai sobre o arrependimento do depoente pelo ato terrorista que teria resultado na morte de um cônsul estrangeiro:

\begin{abstract}
"Comunque lei lo avrebbe fatto in nome di fraintesa giustizia ispiratale da persone che per la loro cultura non avrebbero dovuto approfittare della sua semplicità. E quello che più conta è che lei ne è fermamente pentito. Dirò di più, travolto dal pentimento. Un pentimento che deve confidare non solo alle autorità, ma a un sereno confidente, a un religioso. Lei deve vivere il suo pentimento, ha voglia di spiare" 241 .
\end{abstract}

O diálogo narrado e as poucas interferências do narrador, que se parecem mais com rubricas teatrais, conferem alta densidade dramática ao texto. Como o texto é apresentado por um narrador em terceira pessoa, distanciado do evento narrado, não temos um ponto de vista subjetivo do narrador, e como este não se aproxima dos personagens, também não temos seu acordo ou desacordo com estes, de modo que sua posição ideológica não interfere na narrativa e, além disso, sua visão distanciada permite que os pontos de vista dos personagens se revelem com toda sua plenitude e autonomia. Esse procedimento narrativo pode ser considerado dialógico ${ }^{242}$, já que o narrador cede sua voz aos personagens, não dominando o discurso, deixando que este se construa a si mesmo, com suas vozes divergentes ou concordantes. O conto, aliás, inicia-se com a indicação do policial que dita a um provável escrivão o que o "depoente" deveria dizer em sua confissão durante o suposto interrogatório:

"Io sottoscritto, cognome e nome, desidero rendere piena confessione di tutte le azioni che ho comesso in nome di fraintesa giustizia ispiratami da individui

\footnotetext{
${ }^{241}$ Tabucchi, A. "Il battere d'ali di una farfalla a New York può provocare un tifone a Pechino?". In: Racconti. cit., p. 320. Trad. Bras. Mário Fondelli: "O bater das asas de uma borboleta em Nova York pode provocar um tufão em Pequim?” In: Anjo negro. Rio de Janeiro, Rocco, 1994. p. 79: “- Seja como for, o senhor teria feito aquilo em nome de uma equivocada justiça, inspirada por pessoas que pela cultura que têm não deveriam ter-se aproveitado da sua simplicidade. E o que mais importa é que o senhor está firmemente arrependido. Direi mais, destruído pelo arrependimento. Um arrependimento que deve confessar não só às autoridades, como também a um confidente sereno, um religioso. O senhor deve viver o seu arrependimento, está precisando penitenciar-se".

${ }^{242}$ Uso o termo dialógico aqui no sentido bakhtiniano. Para Bakhtin, a vida é dialógica, está repleta de diálogos, de discursos e linguagens de uma determinada sociedade, inserida em um determinado momento histórico. A palavra de cada indivíduo é perpassada pela palavra do outro, a alteridade marca o ser humano, que se constitui a partir da presença do outro. A soma de todos os discursos e vozes sociais caracteriza a vida humana e torna o discurso não individual, mas uma soma de vários discursos alheios. Cf. Bakhtin, M. M. Problemas da poética de Dostoieviski. 5a. ed. Trad. Paulo Bezerra. Rio de Janeiro, Forense Universitária, 2010. p. 121 e ss.
} 
che hanno approfittato della mia semplicità; azioni delle quali ora sono fermamente pentito" ${ }^{243}$.

Pode-se dizer que as consciências dos personagens são mostradas através do diálogo e, de certo modo, são inconclusas, pois os personagens não se constituem como subjetividade, existe apenas um diálogo entre estas "consciências inconclusas" 244. Assim, os sentimentos que cada personagem manifesta na sua fala expressa uma consciência autônoma, mas fluida e inacessível ao leitor. O narrador observador não estabelece julgamentos sobre os personagens e, por não se aproximar destes personagens, deixa que exerçam de maneira autônoma a sua parte no diálogo.

Os pontos de vista em debate são apresentados de modo a atingir força e plenitude máximas, ao limite da capacidade de convencer. De fato, o policial convence o depoente a entregar os companheiros, a testemunhar contra eles, em nome de um "arrependimento", colocado como histórico-social no plano coletivo, mas que, todavia, se traduz por ressentimento na esfera subjetiva e individual, já que, provavelmente, a posição sócioeconômica e intelectual do depoente o relegava a um mero "executor" de ordens dentro da organização revolucionária. O policial lança mão de uma ótica individualista para arrancar o depoimento, prometendo ao depoente que seu testemunho contra os ex-colegas consistiria na diminuição da sua pena em um processo futuro:

\footnotetext{
"Le posso dire che ci sono altre persone nella sua condizione, voglio dire fermamente pentite delle azioni commesse, sa, il pentimento è come la catena di Sant'Antonio, se qualcuno mi dice qualcosa di lei, lei mi dice qualcosa di un altro, e poi lei sa bene di avere agito spontaneamente, di sua iniziativa, proprio perché era un entusiasta, lei aveva un entusiasmo incontenibile, ma gli entusiasmi si pagano anche dopo trent'anni, non so se lei riesce a quantificare in termini di anni di galera il prezzo da pagare..." ${ }^{245}$.
}

\footnotetext{
${ }^{243}$ Tabucchi, A. "Il battere d'ali di una farfalla a New York può provocare un tifone a Pechino?”. cit., p. 313. Trad. bras. cit., p. 69: “- O abaixo assinado escrevente deseja dar plena confissão de todas as ações que cometeu em nome de uma equivocada justiça que lhe foi inspirada por indivíduos que se aproveitaram da sua simplicidade; ações das quais agora o declarante está firmemente arrependido". ${ }^{244}$ Cfr. Bakhtin, M. Problemas da poética de Dostoieviski. cit., p. 121 e ss.

${ }^{245}$ Tabucchi, A. "Il battere d'ali di una farfalla a New York può provocare un tifone a Pechino?". cit., p. 314. Trad. bras. cit., p. 71: "Posso dizer-lhe que há muitos outros nas suas mesmas condições, isto é, firmemente arrependidos dos atos cometidos, sabe, o arrependimento é como a corrente de Santo Antônio, se alguém me contar alguma coisa do senhor, o senhor vai contar-me alguma coisa de um outro, e aí o senhor sabe muito bem que agiu espontaneamente, por iniciativa própria, justamente porque era um entusiasta, tinha um entusiasmo incontrolável, mas os entusiasmos se pagam mesmo depois de trinta anos, não sei se o senhor consegue quantificar em termos de anos de cadeia o preço a pagar...”.
} 
É assim que no diálogo entram em choque forças contrárias, mas que depois passam a coincidir: a voz do policial se sobrepõe à voz do depoente, de modo a induzilo a narrar aquilo que o policial precisa ouvir. A violência do discurso do policial é matizada e normatizada através da "confissão" (induzida) do depoente.

O narrador tabucchiano não possui, neste conto, um campo de visão abrangente, é um mero observador, que narra os fatos com dificuldade. É uma espécie de expectador que narra a ação como se fosse um espetáculo ao qual presencia, e por este motivo, o sentido total e conclusivo da realidade narrada não pode ser apreendido pelo narrador e, consequentemente, pelo leitor. A complexidade da realidade é sentida pelos personagens e também pelo narrador, mas estes não conseguem lidar com esta experiência de forma unificadora. A posição do narrador é similar à do leitor: ele só conhece o que é dado na imanência dos discursos e das relações estabelecidas no próprio texto, é um narrador que

\begin{abstract}
"transmite uma sabedoria que é decorrência da observação de uma vivência alheia a ele, visto que a ação narrada não foi tecida na substância viva da sua existência. Nesse sentido, ele é o puro ficcionista, pois tem de dar autenticidade a uma ação que, por não ter respaldo da vivência, estaria desprovida de autenticidade. Esta autenticidade provém da verossimilhança, que é produto da lógica interna do relato" ${ }^{\text {246. }}$.
\end{abstract}

A ação narrada no conto se torna uma espécie de espetáculo encenado, em que a instância pública está posta, seja através do interrogatório "não oficial" do policial, seja através do "testemunho" do depoente que trazem para a narrativa a esfera jurídica, uma dimensão coletiva. Este coletivo, entretanto, não se constitui como cidadania, mas como fracasso, já que a solução de um problema aparentemente coletivo se dá apenas no âmbito do privado: o depoimento se dá forçosamente entre quatro paredes; o "arrependimento histórico-social” que pretende o policial é uma farsa tanto do policial quanto do depoente que busca uma diminuição de sua pena, incriminando os companheiros.

O espaço e o tempo são indicados apenas no final do conto, e ainda assim de maneira superficial: a conversa ocorre numa "sala abafada, de janelas fechadas, através das quais se percebia o zunido do trânsito". O espaço da representação é "um lugar

\footnotetext{
${ }^{246}$ Santiago, S. "O narrador pós-moderno". In: Nas malhas da letra. São Paulo, Companhia das Letras, 1989. p. 40.
} 
como qualquer outro, um prédio como qualquer outro", no qual, todavia, "não há placas nas portas", local apropriado, portanto, para encontros anônimos. O tempo também é impreciso: "um relógio, em algum lugar, bate as horas". A carência de uma perspectiva temporal parece resultar da destruição do espaço que, entendido na literatura moderna como espaço da reflexão ${ }^{247}$, atua, nesta narrativa, entretanto, como não-lugar.

Como visto, a representação da realidade se dá de maneira fluida e fragmentada: o narrador não vivencia os fatos, só os observa, sem se comprometer com eles; tempo e espaço são imprecisos. Existe a presença do fato histórico, que vai sendo questionado e modificado pelo narrador. Tabucchi tenta representar a complexidade labiríntica da experiência contemporânea, e quando o faz, percebe a impossibilidade de narrar os fatos de forma objetiva. Assim, a narrativa transita entre uma tentativa de representação realística de um fato histórico e a visão da realidade como parte de um mosaico, o qual é impossível recompor.

A linguagem também se caracteriza por essa fluidez narrativa: ora se aproxima de uma objetividade realística, ora desliza em direção a uma subjetividade problemática. Esta multiplicidade de formas de narrar, ou de se representar o real, mostra que na literatura de Tabucchi existe uma preocupação com esta complexidade do mundo, com a instabilidade das estruturas que sustentam as nossas sociedades. Existe ainda uma necessidade de se colocar a certa distância desta realidade para procurar entender fenômenos complexos, e tentar traduzi-los em um discurso compreensível, forjando, quando necessário, instrumentos narrativos para narrá-10 ${ }^{248}$.

A temática do terrorismo como forma de resgate e atualização da história italiana recente é frequente na produção narrativa tabucchiana. Podemos notar a presença deste tema também nas outras duas coletâneas analisadas por este trabalho: no conto "Dolores Ibarruri versa lacrime amare", de Il gioco de rovescio, analisado anteriormente, temos uma narrativa que é igualmente ambientada durante os Anos de Chumbo italianos - a mãe que chora a perda do filho, morto pela polícia por ter cometido "atos atrozes", tenta reverter a imagem de terrorista do filho contando ao jornalista que a entrevista sobre sua infância alegre, os jogos que fazia junto do pai. A

\footnotetext{
${ }^{247}$ Pontieri, R. "Onde foi parar o sujeito? - Experiências da subjetividade na ficção do século XX." In: Revista Literatura e Sociedade. São Paulo: USP/FFLCH/DTLLC, n. 14, 2012. p 147. (Disponível em: http://dtllc.fflch.usp.br/node/157).
}

${ }^{248}$ Ceserani, R. Raccontare il postmoderno. cit., p. 173. 
mãe tenta, deste modo, resgatar a afetividade e a inteligência do filho como forma de desconstruir a imagem criada pelos jornais.

Em Piccoli equivoci senza importanza, o conto homônimo mostra que os adversários principais de um processo por terrorismo, o juiz e o réu, são, na verdade velhos companheiros de universidade que, devido a uma série de pequenos equívocos e mal-entendidos do acaso, a vida coloca em situação de oposição. Neste conto, o réu é culpado pelo ato terrorista que cometeu, mas também vítima do acaso. São personagens que encarnam "vite andate male non per una decisione o un atto preciso ma per via di 'piccoli equivoci' che inaspettatamente hanno avuto un'importanza decisiva"249.

Ao tematizar o terrorismo dos Anos de Chumbo na Itália, Tabucchi procura recontextualizar os processos históricos dentro de uma situação discursiva que inclui os contextos social, ideológico, histórico e estético. O autor incorpora, assim, o passado recente dentro de sua narrativa e procura registrar sua crítica com relação a este passado. Não entra necessariamente em acordo ou desacordo com a "ordem" ou com a "desordem" deste período, mas questiona as duas, cada uma em relação à outra. Sua narrativa se constitui, assim, como autoconsciência e reflexão metadiscursiva sobre as catástrofes e as mudanças históricas, pois, como afirma Linda Hutcheon, "reescrever ou reapresentar o passado na fícção e na história é revelá-lo ao presente, impedi-lo de ser conclusivo" $^{250}$.

Cabe ressaltar ainda a postura de Tabucchi em relação a uma literatura "engajada", visto que o autor conhece bem as implicações ideológicas de se escrever sobre a história e, frequentemente, declara sua posição política em entrevistas e artigos de jornais. Tabucchi acredita que escrever sobre a história é uma forma de problematizar e refletir sobre esta e, portanto, um "gesto social". Contraria, assim, a perspectiva crítica de Manganelli, que em La letteratura come menzogna, afirma:

\footnotetext{
"Scrivere letteratura non è un gesto sociale. (...) lo scrittore fatica a tenere il passo con gli eventi; (...) i suoi gesti sono goffi e clandestinamente esatti.
}

\footnotetext{
${ }^{249}$ KLOPP, Charles. "Terrorismo e anni di piombo nella narrativa di Antonio Tabucchi". Atas do Colóquio Littérature et "temps des révoltes" (Italie, 1967-1980): 27 a 29 de novembro de 2008. Disponível em: http://colloque-temps-revoltes.ens-lyon.fr/IMG/pdf/LTR 16_Klopp.pdf. Acesso em 09/09/2013. "vidas arruinadas não por uma decisão ou um ato preciso, mas por causa de 'pequenos equívocos' que inesperadamente tiveram uma importância decisiva”.
}

${ }^{250}$ Hutcheon, L. Poética do Pós-Modernismo. cit., p. 147. 
Assai imperfetto è il suo colloquio con i contemporanei. È un fulmine tardivo, i suoi discorsi sono inintelligibili a molti, a lui stesso" ${ }^{251}$.

$\mathrm{O}$ autor reconhece a dificuldade em interagir de modo coerente com seus contemporâneos, prefere fugir à imediatez dos fatos e esperar pela "memória" deles, o que confirma, em parte, a visão de Manganelli de que o diálogo com a contemporaneidade é imperfeito e ambíguo. Todavia, Tabucchi acredita que identificarse com o ponto de vista dos outros é um gesto de consciência social, um modo de explorar as diversidades e de olhar a realidade com os olhos dos outros:

\footnotetext{
"Quel che non ho mai fatto, nei miei libri, è stato parlare di me: mi ritengo del tutto incapace di scrivere un journal intime, preferisco identificarmi nel punto di vista altrui e forse è questa la mia maniera di impegnarmi. Mettermi nei panni di un bambino, di un vecchio, di un moribondo, di un vedovo come Pereira mi permette di allontanarmi dal mio ombelico, mi permette di osservare il mondo attraverso altri occhi. Ritengo che sia proprio questa diversità l'elemento che caratterizza meglio il romanziere: la moltiplicazione dei punti di vista. Il mio 'impegno' consiste nell'esplorare le diversità rispetto a me stesso, nell'indagare la realtà con gli occhi altruiı"252.
}

\footnotetext{
${ }^{251}$ Manganelli, G. La letteratura come menzogna. cit., p. 219: "Escrever literatura não é um gesto social. (...) o escritor se esforça para seguir o passo dos eventos; (...) os seus gestos são desajeitados e clandestinamente exatos. O diálogo com os seus contemporâneos é muito imperfeito. É um relâmpago tardio, os seus discursos são ininteligíveis a muitos, inclusive a si mesmo".

${ }^{252}$ Tabucchi, A. "Catullo e il cardellino". In: MicroMega. Antonio Tabucchi la scrittura e l'impegno. Roma: Gruppo Editoriale L’Espresso. n. 5, 2012. p. 94: “O que nunca fiz, nos meus livros, foi falar de mim: considero-me totalmente incapaz de escrever um journal intime, prefiro me identificar com o ponto de vista dos outros e talvez esta seja a minha maneira de me empenhar. Colocar-me na pele de uma criança, de um velho, de um moribundo, de um viúvo como Pereira, permite me afastar do meu umbigo e observar o mundo por meio de outros olhos. Considero que esta diversidade é justamente o elemento que melhor caracteriza o romancista: a multiplicação dos pontos de vista. O meu 'empenho' consiste em explorar as diversidades em relação a mim mesmo, em indagar a realidade com os olhos dos outros".
} 


\title{
4.3. NATUREZA INTERTEXTUAL DO PASSADO E PROBLEMATIZAÇÃO DO CONHECIMENTO HISTÓRICO: O SALAZARISMO EM PORTUGAL
}

\author{
"Nenhum pensamento de infância,/ nem saudade nem vão propósito./Somente a contemplação/ \\ de um mundo enorme e parado. \\ A soma da vida é nula./Mas a vida tem tal poder:/na escuridão absoluta,/ como líquido, circula. \\ Suicídio, riqueza, ciência.../A alma severa se interroga/ e logo se cala. E não sabe/ \\ se é noite, mar ou distância”. \\ Carlos Drummond de Andrade.
}

Outro conto de L'Angelo Nero ligado à temática histórica, desta vez sobre o salazarismo em Portugal, no final dos anos 1960, é "Notte, mare o distanza". Neste conto, temos quatro jovens e um poeta que, às vésperas da queda da ditadura salazarista, encontram um policial que os assusta e ameaça contando-lhes terríveis ações que teria cometido em Angola, durante a luta anticolonial.

A narrativa é ambientada na cidade de Lisboa e o narrador se esforça por relembrar os fatos ocorridos, ou melhor, imaginar como os fatos ocorreram, nesta "noite fria de um ano distante, novembro de 1969". A data, marcada no texto, remete ao momento histórico que antecede as eleições legislativas que colocaram no poder Marcello Caetano, chefe ministerial que substituiu Salazar e manteve a política do Estado Novo português até sua queda, em 1974. Trata-se de um período em que existe uma esperança de abertura política no país, que será frustrada, entretanto, com o resultado das eleições.

Os quatro jovens de vinte e poucos anos se reúnem na casa do "célebre poeta" Tadeus para jantar, ler poesia e homenageá-lo, visto que ele acabara de publicar um novo volume de poemas. Nesta noite, a conversa parece girar em torno de literatura e política, e os jovens entusiasmados e aflitos se esforçam por acreditar que um período de mudança e abertura política está chegando.

Os fatos não são narrados de modo linear e objetivo. $O$ foco narrativo é particular neste conto, pois o narrador não se constitui como um observador distanciado dos fatos e também não assume a perspectiva de um narrador subjetivo. Ao invés disso, 
temos um "narrador testemunha" 253 , que não se constitui como um "eu", mas que adota o ponto de vista de um "ele", uma terceira pessoa misteriosa, que, conhecendo os fatos ou parte deles, tenta relembrar ou imaginar o que teria acontecido naquela noite distante no tempo. Não conseguimos precisar em nenhum momento do conto a ligação deste "ele" "que imaginava como ocorreram os fatos" com os acontecimentos narrados e sua relação com os personagens da história. Sabemos, todavia, que este mantém alguma relação íntima com o personagem do poeta Tadeus, a ponto de estabelecer julgamentos e questionar sua postura diante dos acontecimentos. A narrativa é construída a partir das reminiscências deste "narrador" problemático - que se autonomeia "imaginação" -, flashes do passado, invenção e sonho que este insere propositalmente na história contada.

Assim, a história começa após o jantar, quando os personagens estão ensaiando uma despedida, mas para a "imaginação daquele que retoma os fatos", a cena se constrói como se os personagens estivessem em um filme e fossem observados por um telespectador com um controle remoto, que avança e recua a cena, tentando captar seus detalhes e compreender em que posição se encontrava exatamente cada um dos personagens, quais gestos fizeram e o que disseram com todas as palavras.

Então, de improviso, uma frase dita por Tadeus retorna na "imaginação daquele que retomava os fatos": "perché è un buon viatico" ("porque é um bom viático"). O contexto da frase não é claro: Tadeus se referia à poesia sobre a qual haviam discutido? Na linguagem eclesiástica, o viático é a comunhão (a hóstia) dada aos fiéis enfermos após a extrema unção, e serve como alimento espiritual para enfrentar a viagem para a outra vida. A poesia é vista, assim, como uma espécie de viático, um alimento que dá força aos jovens para enfrentar a noite lá fora. De qualquer modo, a frase permanece suspensa e aprisiona momentaneamente os personagens, enquanto aquele que retoma os fatos "pausa" a narrativa e tenta reconstruir o sentido da conversa, por meio de digressões, saltos, condensando o passado retomado e o presente em que se relembra.

Percebemos aqui que o narrador é testemunha dos fatos e se encontra, de alguma forma, envolvido neles, e como não detém o controle da narrativa, narra com certa dificuldade já que, como testemunha, não teria acesso à consciência dos outros personagens. Entretanto, o narrador se permite pausar a cena e fazer conjecturas sobre o passado narrado e os sentimentos dos personagens que ali se encontravam, seus anseios

${ }^{253}$ Uso aqui o termo conforme a tipologia de Norman Friedman. 
e medos em relação ao que viveriam naquela noite, como se a história que se está contando já tivesse ocorrido, como de fato já ocorrera. Temos, assim, uma mescla de um narrador "testemunha" com uma consciência onisciente, uma consciência que conhece os fatos narrados de vários ângulos, porque já os retomara várias vezes na memória, que conhece os estados mentais das personagens, porque já os investigara várias vezes. O narrador, entretanto, não se afirma nem como testemunha, nem como onisciente, mas como uma mistura dos dois, uma "consciência estruturante", que tenta consolidar-se como um "eu", mas que encontra limites para a sua formação e afirmação. Todavia, a não constituição de uma subjetividade narrativa como procedimento narrativo implica na desestabilização da própria forma, visto que desafia as convenções realistas tradicionais, que tomam por coerente e contínuo o registro do sujeito ${ }^{254}$.

Quando a cena continua, e a partir daqui sabemos que a cena continua na "imaginação" daquele que retoma os fatos, vemos os jovens colocando os casacos e se preparando para sair, mas um dos jovens, Tiago, provavelmente, aproveita a frase de Tadeus e faz uma saudação: "ao mar, à noite e à lonjura", e Tadeus então os chama para "mais um trago" e retoma o poema, afirmando que o verso diz "distância" e não lonjura, que seriam coisas diferentes. A reabertura do livro para confrontar o que teria dito o poeta lido naquela noite é apenas um pretexto para não enfrentar a noite que preanunciava um desfecho angustiante lá fora:

\begin{abstract}
"Ma non fu per questo che restarono, per riaprire il libro di uno dei poeti che avevano letto quella sera e un verso che difatti diceva: se è notte, mare o distanza. No, lo sapevano tutti che restavano per altro, próprio perché fuori era notte, mare o distanza, e la frase di Tiago aveva manifestato un sentimento che era di tutti e che nessuno aveva il coraggio di rendere esplicito: un disagio, come una tenue malattia"255.
\end{abstract}

O poema lido no conto pertence, na realidade, a Carlos Drummond de Andrade, poeta modernista brasileiro conhecido e admirado por Antonio Tabucchi, que o traduziu

\footnotetext{
${ }^{254}$ Cfr. Hutcheon, L. Poética do Pós-Modernismo. cit., p.116.

${ }^{255}$ Tabucchi, A. "Notte, mare o distanza". In: Racconti, cit. p. 286. Trad. Bras. Mário Fondelli. "Noite, mar ou distância". In: Anjo negro. cit, p. 31."Mas não foi por isso que ficaram, para abrir mais uma vez o livro de um poeta que tinham lido naquela noite e um verso que de fato dizia: se for noite, mar ou distância. Não, todos eles sabiam que ficavam por outro motivo, justamente porque lá fora era noite, mar ou distância, e a frase de Tiago manifestara um sentimento que era de todos e que ninguém tinha a coragem de tornar explícito: um mal-estar, como que uma tênue doença"
} 
do português para o italiano ${ }^{256}$. O verso citado, que também dá nome ao conto, pertence ao poema "Noturno à janela do apartamento", incluído na coletânea $O$ Sentimento do Mundo, de 1940. A referência implícita e o diálogo que se estabelece no conto a partir dela é outro indício de intertextualidade presente na obra tabucchiana que, como já dito, faz uso constante de textos de referência para preencher "lacunas" e estabelecer um significado ou um nexo na narrativa. Várias citações do Sentimento do Mundo estão presentes neste conto, todas em forma implícita e/ou alusiva. A temática histórico-social a que se refere o livro - os anos da Segunda Guerra, e o sentimento de desilusão do poeta em relação à época retratada, ajudam a criar no conto uma atmosfera sombria, de opressão, causada pelo momento histórico vivido pelos personagens, um tempo “desprovido de qualquer ilusão":

“... c'era bisogno di ridere, quella notte. Passavano rare macchine, i lampioni si erano spenti, una trovata della polizia affinché non si formassero per strada gruppetti sovversivi (...) Tiago andò alla finestra e disse che sembrava il coprifuoco, e poi si mise una mano sul petto, come se facesse uno strano giuramento, o come se qualcosa lo opprimesse, e disse: questa volta non riusciranno a vincere, non riusciranno a truccare anche queste elezioni. Ma subito si girò verso i vetri e sussurrò: perché dovrebbero lasciarci vincere?, sono quarant'anni che comandano,"257.

Os jovens se demoram mais um pouco, leem alguns poemas ainda e alguém, talvez Joana ou Luísa, propõe um brinde "à poesia". Tadeus então repete a frase "porque é um bom viático" e quem "estava pensando em como as coisas poderiam ter acontecido naquela noite" percebe que a frase de Tadeus criava um círculo vicioso, já que os amigos novamente colocavam os casacos, despediam-se e avançavam em direção à porta. Mas não saíam. A "imaginação" os detinha ali, ou os fazia recuar, "da porta às poltronas", e avançar de novo, "das poltronas à porta", como se fossem "povere creature stregate e condannate a una ripetizione insensata, forzate a mimare e a ripercorrere il

\footnotetext{
${ }^{256}$ Drummond de Andrade, C. Sentimento del mondo. Trad. Antonio Tabucchi. Turim: Einaudi, 1987.

${ }^{257}$ Tabucchi, A."Notte, mare o distanza”. cit. p. 287. Trad. bras. cit., p. 32. “... era preciso rir naquela noite. Passavam poucos carros, os lampiões estavam apagados, uma ideia da polícia para que não se formassem grupos subversivos na rua (...) Tiago foi até a janela e disse que parecia um Estado de sítio, e aí botou uma mão no peito, como fazendo um estranho juramento, ou como se algo o oprimisse e disse: desta vez não vão conseguir vencer, não vão conseguir roubar nestas eleições. Mas logo virou-se para os vidros e murmurou: por que deveriam nos deixar ganhar?, já estão no comando há quarenta anos".
} 
preludio all'avventura atroce che le aspettava nella notte"258. A "imaginação" não tinha coragem de deixar os personagens viverem a aventura como deveriam vivê-la.

Finalmente eles saem, descem as escadas e escapam finalmente do "círculo vicioso da imaginação" e, envolvidos pela noite, enfrentam o destino que lhes cabe: já na rua, chega um carro de faróis apagados, silencioso, a janela entreaberta, e de lá de dentro um ocupante indistinguível aponta-lhes uma pistola, obrigando-os a parar e estender as mãos: “fermi così, signorini, ora restate per un po' fermi così, ma girate le spalle e alzate le manine" ${ }^{\text {259 }}$. O uso do diminutivo é sentido pelos jovens como parte de uma "violência compacta", ou assim julga a "imaginação que narra os fatos".

O homem armado obriga todos a se manterem de costas, virados para o muro e pede aos jovens que entreguem os casacos para serem revistados. Às moças, pede as bolsas. Da janela do carro, vê-se uma mão estendida, "era una mano grassa, con il dorso leggermente gonfio e le dita robuste e corte" ${ }^{260}$, que revista os casacos, depois a bolsa, e depois os atira no chão, entre a calçada e o carro. A partir deste momento, a "imaginação" de quem estava pensando os fatos gera, conscientemente, um bagre - da janela do automóvel, os jovens veem o focinho de um bagre oleoso e arquejante:

"E fu a quel punto che arrivò la cernia. Era una cernia pingue, lustra, oleosa, che guizzava su dei fondali oscuri come l'oscurità dell'automobile che minacciava le vittime di quella notte: dal finestrino, assieme a una mano gonfia delle dita tozze si affacciò il muso di una cernia che boccheggiava. Che cosa inspiegabile, una mano e un muso di cernia dal finestrino di un'automobile nera nella Rua Dom Pedro Quinto in una notte di novembre del millenovecentosessantanove",261.

A “imaginação que retoma os fatos" tem consciência da estranheza da cena, mas julga mais absurdo o fato de parecer perfeitamente natural aos jovens que da janela do

\footnotetext{
${ }^{258}$ Tabucchi, A."Notte, mare o distanza". cit. pp. 288-9. Trad. bras. cit., p. 34: "criaturas enfeitiçadas e condenadas a uma repetição insensata, forçadas a recitar e a percorrer mais uma vez o prelúdio da aventura atroz que esperava por eles na noite".

${ }^{259}$ Tabucchi, A."Notte, mare o distanza". cit., p. 289. Trad. bras. cit., p. 35: "paradinhos aí, os meninos vão ficar assim mesmo, mas virem-se lentamente e podem ir levantando as mãozinhas".

${ }^{260}$ Tabucchi, A."Notte, mare o distanza". cit., p. 290. Trad. bras. cit., p. 36: "era uma mão gorda, com o dorso ligeiramente abaulado e os dedos robustos e curtos".

${ }^{261}$ Tabucchi, A."Notte, mare o distanza". cit., p. 290. Trad. bras. cit., p. 36: "E foi aí que entrou em cena o bagre. Era um bagre gordo, lustroso, oleoso, que chispava sobre fundos tão escuros quanto a escuridão do carro que ameaçava as vitimas daquela noite: na janela, junto com uma mão inchada, de dedos atarracados apareceu o focinho de um bagre que arquejava. Que coisa absurda, uma mão e um focinho de bagre na janela de um carro preto na rua Dom Pedro V numa noite de novembro de 1969”.
} 
carro ameaçador aparecesse um bagre. A cena da violência sofrida pelos jovens adquire, assim, um caráter de naturalidade, a violência da polícia daquele regime se torna tão natural quanto o fato de um bagre surgir na janela de um carro escuro. Em um conto aparentemente realista, o bagre, conforme o próprio autor declara, aparece como alegoria de um regime totalitário que consegue produzir somente seres monstruosos:

\begin{abstract}
"In un racconto (...) ho fatto uscire una cernia dal finestrino di un' automobile guidata da un losco figuro della polizia politica di un regime totalitario. Ebbene, le assicuro che quella cernia non c'era, esce dalla mia immaginazione. Sa, in un racconto realistico, di quella realta' che lei venderebbe volentieri nei suoi almanacchi, io ho introdotto una cernia che scivola fuori dal finestrino di una Mercedes nera. (...)È il racconto che ha prodotto quella cernia, sono il poliziotto e la ferocia della dittatura che lui difendeva. Perche' quella cernia, oleosa, puzzolente, moribonda, mi sembrava l'allegoria di un regime totalitario che ormai produceva solo esseri mostruosi" ${ }^{262}$.
\end{abstract}

O bagre escorrega para fora do carro e cai no mesmo lugar em que a "mão" metonímica tinha jogado os casacos dos jovens e as bolsas das moças.

\begin{abstract}
"E lì, nel rigagnolo sudicio, la cernia giacque immobile, appena con qualche debole guizzo di coda, boccheggiando. Stava morendo. Era una grassa cernia boccheggiante che stava morendo" 263 .
\end{abstract}

Joana se aproxima do animal, mas Tiago a detém dizendo para não tocar nele, porque era um peixe imundo. E exige uma identificação do homem do carro.

Quem está relembrando os fatos tem consciência de que o bagre só existia em sua imaginação. É um "narrador" que sabe estar misturando à realidade narrada uma fantasia grotesca, mas que julga legítimo o procedimento, pois sabe que é uma tentativa

\footnotetext{
${ }^{262}$ Tabucchi, A. "Dialogo fra un romanziere e un venditore di almanacchi". In: Corriere della sera, 24/07/1994. "Em um conto (...) fiz um bagre sair da janela de um automóvel guiado por uma figura sombria da polícia política de um regime totalitário. Pois bem, asseguro-lhe que aquele bagre não existia, sai da minha imaginação. Sabe, em um conto realista, desta realidade que o senhor venderia de bom grado nos seus almanaques, eu introduzi um bagre que desliza para fora de uma Mercedes preta. (...) foi o conto que produziu aquele bagre, foram o policial e a ferocidade da ditadura que ele defendia. Porque aquele bagre, oleoso, fedido, moribundo, parecia-me a alegoria de um regime totalitário que produzia agora apenas seres monstruosos".

${ }^{263}$ Tabucchi, A."Notte, mare o distanza". cit., p. 290. Trad. bras. cit., p. 37: "E ali, no sujo regato, o bagre ficou imóvel, somente com alguns fracos pulos do rabo, arquejando. Estava morrendo. Era um pesado bagre arquejante que estava morrendo".
} 
da fantasia de traduzir a irracionalidade e o absurdo do evento descrito. O "narrador" se mostra, neste momento da narrativa, consciente de seu processo "imaginativo-criativo", e o conto se apresenta como metaliterário: o fazer poético é refletido e o processo criativo é colocado em cena, misturado à narrativa, mostrando ao leitor que a literatura se constrói de várias coisas, e que a realidade é apenas mais uma matéria para a invenção.

Assim, a "imaginação que retoma os fatos" faz Joana se abaixar para pegar o peixe e segurá-lo no colo, parecendo niná-lo. Isto se dá, conscientemente, na cena inventada. Na cena relembrada, que o "narrador" coloca ao lado da inventada, Joana apanha a bolsa que a "mão" deixara cair da janela, a mesma mão que segura uma carta que havia sido retirada da bolsa e lida em tom irônico pelo policial. Tiago intervém dizendo que a carta era de seu noivo e que o homem não tinha o direito de lê-la, e por isto, recebe um golpe de pistola na boca, que lhe faz cuspir sangue. É nesse momento que o homem desce do carro, com um chapéu de abas largas que lhe cobre o rosto e se apresenta como polícia política, pedindo a Tiago que lhe mostre seus documentos. Também é nesse momento que Tadeus aparece no portão.

Ao mesmo tempo, a "imaginação que narra os fatos" faz Tadeus surgir no portão e o imagina atrás das cortinas da janela, lá do segundo andar, e se pergunta por que só agora Tadeus resolvia descer e intervir nos acontecimentos, a favor dos jovens. A "imaginação", a partir daqui, torna-se mais vacilante, sofre "una specie di paralisi, o di sonno: una sospensione degli atti o degli eventi che era anche una sospensione e un'immobilità di tutti i personaggi di quella scena"264 . E congelando a cena, afasta-se dela para focalizar o narrador, "aquele que estava imaginando os fatos", sentado em um banco do jardim do Príncipe Real, de onde era impossível precisar os detalhes da cena principal.

O "narrador" volta a "testemunhar" os fatos e se questiona sobre a precariedade de seu "testemunho", pois da posição em que se encontra, a "imaginação que retoma os fatos" não consegue perceber com exatidão quem entra no carro com Tiago para buscar os documentos que havia deixado dentro do carro estacionado em frente da casa de Joana. Primeiro julga que Tadeus havia permanecido em sua casa, Luísa teria sido dispensada pelo policial, e no carro entravam Joana, Michel e Tiago. Então, "aquele que

\footnotetext{
${ }^{264}$ Tabucchi, A."Notte, mare o distanza". cit., p. 292. Trad. bras. cit., p. 39: "uma espécie de paralisia ou de sono: uma interrupção dos atos ou dos acontecimentos que também era uma interrupção e uma imobilidade de todos os personagens daquela cena".
} 
estava imaginando os fatos", do banco do jardim, vê o carro, que agora percebe ser uma Mercedes, partir a toda velocidade.

Depois, num movimento de aproximação, se desloca para dentro do carro, e se coloca entre Michel e Joana, enquanto Tiago senta no banco da frente e pressiona um lenço sobre a boca. Quando o policial, após dirigir com muita velocidade e frear violentamente, começa a dar "lições políticas" aos jovens, Tadeus interfere dizendo que conhece bem a lição política que o policial pretende expor. Então aquele que imagina os fatos percebe que obviamente Tadeus jamais teria permitido que os jovens entrassem sozinhos no carro. A cena é refeita, e desta vez Tadeus entra no carro com os jovens, e aquele que imagina a cena é transportado de volta ao banco do jardim, de onde tem a visão dos fatos prejudicada.

Na outra versão retomada pela "imaginação" vacilante, após a averiguação dos documentos feita pelo policial, Tadeus teria se despedido dos jovens e voltado a pé para casa, e quando já estava longe, o homem teria voltado a sacar a pistola e exigido que os jovens entrassem novamente no carro e de pé, do lado de fora, começado a colocar a primeira regra de sua "lição política": amar o próprio país, sendo que, para fazê-lo, era necessário ódio, "odio per difendere la nostra civiltà e la nostra razza" ${ }^{265}$, e teria iniciado um discurso sobre a dominação das raças consideradas inferiores através da violência, do assassinato dos homens e do estupro das mulheres.

Joana sai do carro cambaleando, e "aquele que imagina os fatos" a vê, de longe, curvada, como se estivesse vomitando, e enquanto os dois jovens saem para ampará-la, a Mercedes dá a partida e se afasta com fúria. Joana recusa a ajuda dos amigos e diz querer voltar só para casa. Os dois vão embora de cabeça baixa, sentindo-se culpados sem saber exatamente do quê. Então, "aquele que estava imaginando os fatos", pensa que a história precisa "concludersi, sciogliersi, o trovare una piega nella quale nascondere se stessa e ciò che aveva provocato nell'animo di qualcuno"266.

Aqui temos novamente um momento metaliterário na narrativa, além da afirmação de um modo de fazer literário: Tabucchi coloca o tema da invenção e do sonho como formas de simplificação, de estabelecimento da completude. Ou seja, quando a realidade narrada se mostra inverossímil e não oferece uma possibilidade de

\footnotetext{
${ }^{265}$ Tabucchi, A."Notte, mare o distanza". cit., p. 294. Trad. bras. cit., p. 43: "ódio para defender a nossa civilização e nossa raça".

${ }^{266}$ Tabucchi, A."Notte, mare o distanza". cit., p. 295. Trad. bras. cit., p. 44: "concluir-se, resolver-se, ou encontrar uma prega na qual esconder a si mesma e aquilo que provocara na alma de alguém".
} 
compreensão dos fatos que se apresentam desprovidos de sentido, a escrita se ocupa, por meio do sonho e da fantasia, de dar uma explicação "plausível" ou, ao menos, de oferecer uma possibilidade de refúgio:

"A volte una soluzione sembra plausibile solo in questo modo: sognando. Forse perché la ragione è pavida, non riesce a riempire i vuoti fra le cose, a stabilire la completezza, che è una forma di semplicità, preferisce una complicazione piena di buchi, e allora la volontà affida la soluzione al sogno",267.

A narrativa afirma, assim, a possibilidade de simplificação da realidade através da imaginação, do sonho, apontando para uma solução "irracional”, que é sentida, entretanto, como a única possível, já que a realidade perde sua "razão" de ser. Consciente do absurdo da realidade, a "imaginação daquele que retoma os fatos" opta por um final admissível, razoável, mas no âmbito da fantasia: começa a seguir Joana pelas ruas da cidade até chegar diante do portão de Tadeus, onde este já a esperava, com o seu sorriso habitual, uma espécie de riso liberatório, que caracteriza a personalidade sarcástica de Tadeus, como se este sorriso quisesse dizer: "ti aspettavo, lo sapevo che saresti venuta, che non avresti resistito alla tentazione"268. E Joana concorda, admitindo que não se pode resistir às coisas que devem ser feitas. E depois se curva para pegar o bagre arquejante, dizendo que não podiam deixar ali o animal. E "aquele que imaginava os fatos" imagina "bizarramente" que os dois sobem as escadas montados no bagre moribundo:

“... e curioso, che la cernia, guizzando con i suoi esausti colpi di coda, salisse la spirale delle scale una volta, due volte, tre volte, fino a entrare in un vortice che evadeva da quella casa e attraversava pareti e tempo; caparbia, oleosa, moribonda ma instancabile: avanti, anno dopo anno, mentre la vita passava,

\footnotetext{
${ }^{267}$ Tabucchi, A. "Rebus” In: Racconti. cit., p. 149: “Às vezes uma solução parece plausível apenas deste modo: sonhando. Talvez por ser pávida, a razão não consiga preencher os vazios entre as coisas, estabelecer a completude, que é uma forma de simplicidade, e prefira uma complicação cheia de buracos e, então, a vontade confia a solução ao sonho".

${ }^{268}$ Tabucchi, A."Notte, mare o distanza". cit., p. 296. Trad. bras. cit., p. 45: "estava esperando por você, eu sabia que você voltaria, que não conseguiria resistir à tentação".
} 
anni e anni, per approdare un giorno fino a lui, la cernia; lui che ora stava imaginando quella notte di tanti anni prima. Fino a lui e fino a dove?”269.

A cena final dos dois montados no bagre parece sugerir que o narrador está recordando fatos que vivera, de alguma forma. O final remete ao "despertar" de um sonho, de uma lembrança. A imagem final "criada" pela imaginação retoma um quadro muito caro a Tabucchi, citado também em Requiem: As tentações de Santo Antão, de Hieronymus $\operatorname{Bosch}^{270}$. A alusão ao quadro é uma espécie de intertexto pictórico, numa forma de intertextualidade que tenta "incorporar o passado textualizado no texto do presente", pois, de acordo com Linda Hutcheon,

“A intertextualidade é, na narrativa contemporânea, uma manifestação formal de um desejo de reduzir a distância entre o passado e o presente do leitor e também de um desejo de reescrever o passado dentro de um novo contexto (...). Não é uma tentativa de esvaziar ou evitar a história"271.

É um confronto direto com o passado, pelo "uso e abuso de ecos intertextuais" e pela inserção de "poderosas alusões" que subvertem a ordem narrativa por meio da ironia e da paródia destas mesmas formas narrativas.

N'As tentações de Santo Antão, as visões de fim do mundo são materializadas em um painel que mostra a fustigação do homem por demônios e monstros imaginários, incêndios, traduzindo o pessimismo e as ansiedades do pintor em relação a uma época de revoltas políticas e conflitos sociais, além de mostrar uma formação religiosa rígida, baseada nos moldes da Igreja Medieval. O mundo retratado no painel é grotesco e fantástico, e evoca o bizarro numa época em que predomina o belo renascentista. Em um dos detalhes do quadro vemos um homem e uma mulher, talvez uma bruxa e seu servo, montados em um enorme peixe que voa por sobre a cidade incendiada, afastandose do Mal que lá predomina. É um detalhe curioso, visto que os dois escapam do horror do pecado e do caos retratado, possibilidade delegada só à figura de Santo Antão, que

\footnotetext{
${ }^{269}$ Tabucchi, A."Notte, mare o distanza”. cit., p. 296. Trad. bras. cit., p. 45: “... e, curioso, que o bagre, pulando com os seus exaustos estalos do rabo, subia a espiral da escada uma vez, duas vezes, três vezes, até entrar num redemoinho que escapava daquela casa e atravessava as paredes e o tempo; cabeçudo, oleoso, moribundo, mas incansável: para frente, um ano depois do outro, enquanto a vida passava, anos e mais anos, para um dia chegar até ele o bagre; ele que agora estava imaginando aquela noite de tantos anos atrás. Até ele e até onde?".

${ }^{270} \mathrm{O}$ quadro de Bosch se encontra no Museu de Arte Antiga de Lisboa.

${ }^{271}$ Hutcheon, L. Poética do Pós-Modernismo. cit., p. 157.
} 
permanece sentada serena diante do caos e da perdição dos homens ao seu redor, mergulhado na sua espiritualidade e fé, que o fazem escapar da presença dos demônios e dos sofrimentos infligidos aos demais seres.

O final de "Notte, mare o distanza" remete a estas figuras que escapam do Mal, fazendo notar o papel de destaque da fantasia na fuga de uma realidade monstruosa e terrificante. O "narrador", como vimos, é um narrador que demonstra ter consciência da impossibilidade de representar esta realidade de forma realista, tanto quanto de resgatar e representar o passado tal como foi, pois sabe que só se pode conhecer o passado por meio de seus "vestígios textualizados". Ele se utiliza, desta forma, de procedimentos como a intertextualidade, a paródia, a subversao dos gêneros na formalização da matéria histórica. Seria possível dizer, por exemplo, que o conto se apropria e depois subverte a forma da narrativa de testemunho, pois de acordo com Ricoeur, os relatos testemunhais são discursos que implicam, em sua enunciação, o narrador em sua história: a condição do "testemunho" é um narrador implicado nos fatos, que não persegue uma verdade externa no momento em que ela é enunciada ${ }^{272}$.

Percebemos, todavia que, no conto, a "testemunha" deste passado não é confiável, primeiro porque não se inscreve no texto como um "eu" que presenciou os fatos, colocando-se, antes, como um "ele" que tenta imaginar como teriam acontecido estes fatos. Em segundo lugar, não sabemos que relação aquele que observa/imagina a história estabelece com os fatos narrados; de que ponto de vista narra; como tem consciência dos anseios, dos sentimentos dos outros personagens, visto que a cena descrita é narrada de modo indireto, falsificada pela memória e pela imaginação.

Desta forma, o "narrador" ao se identificar na narrativa como "aquele que imaginava os fatos", não se inscreve como sujeito de uma experiência vivida, que tenta comunicá-la construindo, a partir disso, o sentido de sua experiência. Ao invés disso, temos um narrador que se coloca como testemunha problemática da cena descrita, que lida com a história factual a partir de um jogo de desconstrução dos próprios fatos narrados. O narrador percebe que o passado tal como foi é inacessível, que e a memória deste passado se apresenta corrompida seja pelo tempo, seja pela fantasia (que agrega um "bagre" à história).

\footnotetext{
${ }^{272}$ Ricouer apud Sarlo, Tempo passado: cultura da memória e guinada subjetiva. Trad. Rosa Freire d'Aguiar. São Paulo: Companhia das Letras/ Belo Horizonte: UFMG, 2007. p. 49.
} 
Outra questão ligada à problemática do narrador é o movimento de aproximação e distanciamento que este empreende durante a narrativa, mudando de perspectiva e de voz verbal, o que acaba por desestabilizar as bases da narrativa. Ao se aproximar e depois se distanciar dos fatos narrados, o narrador sofre um processo de fragmentação de sua identidade, obrigando o leitor a se perguntar várias vezes "quem está narrando? e de qual ponto de vista?". Como dissemos, ele passa de "testemunha" que observa os fatos à "testemunha" que teria vivenciado de alguma forma os fatos. Além disso, essa fragmentação do narrador reverbera no leitor, que primeiramente é colocado distante e depois próximo dos fatos, penetrando na narrativa, e depois é jogado para fora dela. Esta frequente alternância do ponto de vista narrativo complica a implantação da subjetividade na linguagem, já que a insere e a desestabiliza ao mesmo tempo. Também mostra a complexidade da enunciação na narrativa contemporânea por meio da problematização da noção geral de subjetividade, fazendo com que a percepção do sujeito narrativo se dê não em termos de uma noção humanista, mas como resultado de processos que parecem ser exteriores ao próprio sujeito (a política, a história, etc) ${ }^{273}$.

A narrativa lida, assim, com a subversão da estabilidade do ponto de vista - o ponto de vista é o que, no romance, estabelece a garantia da subjetividade na narrativa $^{274}$. No contexto da narrativa contemporânea e pós-moderna, de acordo com Linda Hutcheon, a problematização da inserção da subjetividade se dá de duas formas: mediante narradores declarados, deliberadamente manipulativos ou por meio de inúmeras vozes que não são inteiramente localizáveis no universo textual, como nos romances sem uma perspectiva única. $\mathrm{O}$ uso de uma subjetividade múltipla não nega a subjetividade em si, mas desafia a noção tradicional no que se refere a sua unidade e a sua função. Assim, o poder totalizante da narrativa, da história e das noções que temos sobre o sujeito é subvertido. Ainda, temos uma perturbação e/ou dispersão da noção de sujeito individual e coerente e sua relação com a história, com a formação social e com seu próprio inconsciente. O sujeito linguístico se torna descontínuo ou sofre uma hipertrofia $^{275}$ - passa a ser estruturado pela linguagem como diferença, e não como uma consciência autônoma unificada. Desta forma, podemos perceber que os múltiplos pontos de vista na narrativa pós-moderna impedem qualquer conceito totalizante da

\footnotetext{
${ }^{273}$ Hutcheon, L. Poética do Pós-Modernismo. cit., p.116.

${ }^{274}$ Hutcheon, L. Poética do Pós-Modernismo. cit., pp.116 e ss.

${ }^{275}$ Pontieri, Regina. "Onde foi parar o sujeito? - Experiências da subjetividade na ficção do século XX." cit.
} 
subjetividade do narrador, e ao mesmo tempo, impedem que o leitor encontre qualquer posição de sujeito a partir da qual possa se identificar e dar coerência à narrativa.

Pode-se dizer que Tabucchi adota este procedimento formal na construção dessa e de outras narrativas, ou seja, vale-se de uma subjetividade múltipla, manipuladora e vacilante, fazendo com que a visão do leitor em relação ao narrador e aos personagens seja constantemente colocada em xeque: em determinado momento Tadeus é visto como um poeta desiludido e covarde, que abandona os jovens à própria sorte, para em seguida ser o redentor que, se não os salva de um evento terrível, ao menos evita consequências mais trágicas.

Partindo dessas considerações, podemos inferir que Tabucchi é um escritor consciente dos procedimentos narrativos de que dispõe para narrar e que, justamente por perceber a complexidade dos fatos que pretende apresentar ao leitor, sabe que a narrativa, em seus moldes tradicionais, não dá conta de lidar com as questões de seu tempo. Daí a opção pela paródia e pela intertextualidade, pela desconstrução das formas tradicionais e pela metaliteratura, procedimentos formais que, como podemos observar, estão presentes neste e em outros de seus contos analisados anteriormente. 


\title{
4.4. PRESENÇAS MALÉFICAS EM L'ANGELO NERO
}

\author{
"O grande angelo nero \\ fuligginoso riparami \\ sotto le tue ali" \\ Eugenio Montale.
}

L’Angelo Nero e Requiem são escritos e publicados praticamente juntos, em 1991 e 1992, respectivamente, e não só citam o quadro de Bosch, como também se aproximam da técnica de composição do pintor medieval:

\begin{abstract}
"Con una tecnica che lo avvicina al maestro dell'ultima demonologia medievale, anche Tabucchi costruisce storie dentro storie (quadri dentro quadri) fa sfilare personaggi, individuandone uno centrale, passa dalla bellezza della forma alla simbologia del male, trasforma le cose, pone intorno a una catastrofe personaggi enigmatici, figure inquietanti. In una struttura narrativa non obbligata, proprio come nelle Tentazioni di Sant'Antonio, la sua sequenza narrativa, in sintonia con il nuovo spirito dei tempi, non procede però verso la salvezza ma verso la perdizione",276.
\end{abstract}

Os dois livros apresentam também outro ponto comum: a figura recorrente do personagem Tadeus, presente em dois contos de L'Angelo Nero, além de ser um dos "mortos" que o narrador visita em Requiem.

O personagem do poeta Tadeus, que aparece em "Notte, mare o distanza", é também a voz irônica e maléfica que impulsiona o narrador a quase cometer um suicídio em "Voci portate da qualcosa, impossibile dire cosa", conto que abre o livro L'Angelo Nero. Nesta metanarrativa, temos um narrador personagem interessado nas "fissuras do real", no acaso que o destino pode lhe trazer. O conto se inicia com a descrição de um

\footnotetext{
${ }^{276}$ Dolfi, A. Tabucchi, la specularità, il rimorso. cit., p. 206. "Com uma técnica que o aproxima do mestre da última demonologia medieval, Tabucchi também constrói histórias dentro de histórias (quadros dentro de quadros); faz desfilar personagens, individuando, entre eles, um central; passa da beleza da forma à simbologia do mal; transforma as coisas; dispõe ao redor de uma catástrofe, personagens enigmáticos, figuras inquietantes. Em uma estrutura narrativa não forçada, assim como nas Tentações de Sant'Antão, a sua sequência narrativa, em sintonia como o novo espírito dos tempos, não se dirige, porém, para a salvação, mas rumo à perdição".
} 
processo criativo muito utilizado por Tabucchi em suas narrativas: o jogo. "A volte può prendere il via con un gioco, un piccolo gioco segreto e quasi infantile che solo tu conosci"$^{277}$.

A narrativa é concebida como jogo, um jogo aparentemente inofensivo, e para dar início a este jogo, basta, de acordo com a voz narrativa, "dar umas voltas" pela cidade num domingo qualquer e ficar atento às vozes que falam e contam histórias: "basta una frase e tu decidi che è quella, la estrai dal discorso come un chirurgo che con le pinze prende un brandello di tessuto e lo isola" ${ }^{278}$. Partindo desta frase, nasce a história que será contada:

\begin{abstract}
"una storia del tutto diversa dalle storie che hanno raccontato tutti quelli ai quali hai rubato questa storia e che invece appartiene solo a te (...) ognuno ha fornito un piccolo tassello, una pietruzza che tu hai raccolto, scelto, sistemato al posto che le competeva, quello e solo quello, per formare il mosaico che stasera guarderai con occhi avidi, stupito di vedere come le cose si svolgono, come una parola si incastra nell'altra, un fatto nell'altro, un particolare nell'altro fino a creare una faccenda che non esisteva e che ora esiste: la tua storia, 279 .
\end{abstract}

Os emissores das vozes e frases não conhecem o significado, ao menos não aquele último, que será dado pelo escritor, único capaz de agrupar, em um quadro compacto, tantos elementos aparentemente aleatórios, conferindo um sentido a uma história que a partir de um incipit colhido ao acaso, poderá se desenvolver sozinha, de acordo com uma regra combinatória ${ }^{280}$.

O conto se inicia com o narrador explicando ao seu leitor como criar uma narrativa a partir do uso de vozes fragmentárias, ouvidas ao acaso pela cidade, como

\footnotetext{
${ }^{277}$ Tabucchi, A. "Voci portate da qualcosa, impossibile dire cosa". In: Racconti. cit., p. 273. Trad. Bras. Mário Fondelli."Vozes trazidas por alguma coisa, impossível dizer o quê". In: Anjo negro. cit., p. 11: "Às vezes pode começar com uma brincadeira, uma pequena brincadeira secreta e quase infantil que só você conhece".

${ }^{278}$ Tabucchi, A. "Voci portate da qualcosa, impossibile dire cosa". cit., p. 273. Trad. bras. cit., p. 11: "basta uma frase e você decide que é aquela mesma, tira-a do contexto como um cirurgião que com todo o cuidado tira um frangalho de tecido e o isola".

${ }^{279}$ Tabucchi, A. "Voci portate da qualcosa, impossibile dire cosa". cit., p. 274. Trad. bras. cit., p. 12: "algo inteiramente diferente das histórias que contaram todos aqueles dos quais você roubou a história e que portanto só a você pertence, nem mesmo poderiam reconhecê-la, cada um forneceu uma pequena peça, um pedacinho que você apanhou, escolheu, ajeitou no lugar mais apropriado, aquele e somente aquele, para formar o mosaico que à noite irá examinar com os olhos ávidos, surpreso ao ver como as coisas se desenvolvem, como uma palavra se engata na outra, um fato no outro, um detalhe no outro até criar um negócio que não existia e que agora existe: a sua história".
}

${ }^{280}$ Dolfi, A. Tabucchi, la specularità, il rimorso. cit., p. 184. 
combiná-las numa história, quando, de improviso, se manifesta uma voz inconfundível: “nasale, un po' strascicata, con qualcosa di ironico nel timbro, è una voce che hai conosciuto troppo bene" ${ }^{\text {281 }}$. A voz é de Tadeus, um amigo já morto, portanto, uma voz fantasmática, que se exprime com palavras incoerentes, com frases truncadas, enigmáticas, incompletas, criando abismos de significados inesperados, fazendo emergir fragmentos de um passado até então esquecido ou recalcado pelo narrador: "Non sono mai riuscito a dirtelo prima, ma ora è necessario che tu lo sappia"282.

O narrador é, assim, surpreendido pelo próprio jogo. O narrador que descreve metaliterariamente um jogo combinatório, um procedimento de escrita criativa a partir do acaso, torna-se personagem que sofre a força do acaso, sem poder compreender a brincadeira do destino: "Tadeus, ti prego, ti ho sentito; che cosa vuoi dirmi, da dove mi parli, non è possibile, tu non ci sei più, non puoi esserci con la voce"283.

$\mathrm{O}$ acaso e a coincidência se impõem neste conto como valor. As frases que o narrador ouve casualmente o atordoam, pois percebe fazer parte de uma brincadeira do destino, ser presa do próprio jogo. Ele entende que a vida é feita de "estranhas combinações desprovidas de sentido", e esta percepção coloca em dúvida o valor da razão e a veracidade das coisas.

O escritor se utiliza, nesse e em outros contos, de procedimentos combinatórios já utilizados por Manganelli, Calvino, Georges Perec e outros expoentes da neovanguarda francesa, além de se valer, como em "Any where out of the world", do uso de uma segunda pessoa como voz narrativa, mostrando a tendência do protagonista a falar consigo mesmo, a dialogar com a própria alma e com os próprios fantasmas interiores $^{284}$. Esse processo é descrito por Calvino da seguinte forma:

“(...) a pessoa eu, explícita ou implícita, fragmenta-se em diferentes figuras, num eu que está escrevendo e em outro eu que é escrito, num eu empírico

\footnotetext{
${ }^{281}$ Tabucchi, A. "Voci portate da qualcosa, impossibile dire cosa". cit., p. 276. Trad. bras. cit., p.16: "fanhosa, um tanto arrastada, com algo irônico no timbre, é uma voz que você já conheceu até bem demais".

${ }^{282}$ Tabucchi, A. "Voci portate da qualcosa, impossibile dire cosa". cit., p. 276. Trad. bras. cit., p.16: "Nunca consegui dizer-lhe antes, mas agora é preciso que você saiba". (Grifos do autor)

${ }^{283}$ Tabucchi, A. "Voci portate da qualcosa, impossibile dire cosa". cit., p. 277. Trad. bras. cit., p. 17: "Tadeus, lhe peço, ouvi você; o que quer contar-me de onde fala comigo, não é possível, você já não existe, não pode estar aqui com sua voz".

${ }^{284}$ Sobre o uso destes procedimentos por Tabucchi, cfr. Ceserani, R. "Qualche considerazione sulla modernità liquida". cit., p. 19. Sobre Calvino e a arte combinatória, cfr. Berardinelli, A. "Calvino moralista ou como permanecer são depois do fim do mundo". Trad. Maria Betânia Amoroso. In: Revista Novos Estudos CEBRAP, n.54, jul. 1999. pp. 97-113.
} 
que está atrás do eu que escreve e num eu mítico que serve de modelo ao eu que é escrito. $\mathrm{O}$ eu do autor que escreve se dissolve: a chamada 'personalidade' do escritor é interna ao ato de escrever, é um produto e um modo da escritura"285.

Tabucchi se utiliza também da inversão sistemática dos significados e das verdades estabelecidas como técnica narrativa, obrigando o leitor a pensar na relatividade, na provisoriedade e na precariedade de cada perspectiva. Desta inversão deriva a sensação de desorientamento espaço-temporal do narrador, comum a muitos de seus personagens. A percepção do tempo e do espaço é sentida como vastidão: “l'ora è vasta siccome lo spazio in cui domina la legge del radicalmente discontinuo, del giustapposto e dell'incompatibile"286.

O espaço geográfico se submete à lógica do acaso e é deste "além" espacial que provém a voz inquietante de Tadeus, que traz consigo as recordações do narrador, de acontecimentos passados que nunca foram realmente compreendidos. $\mathrm{O}$ narrador então se esforça para reconstruir estes eventos, colocar ordem no caos, mas todo esforço para organizar estes pensamentos se revela inútl:

\begin{abstract}
"È impossibile pensare a tutto assieme, bisogna prendere le cose per ordine, ma le cose hanno un ordine? E a quale ordine si riferisce una frase come questa: a quale tempo, a quale momento, a quale circostanza? A tutto, può riferirsi a tutto, dunque è inutile pensare le cose per ordine, lasciale pure venire così come vengono" ${ }^{287}$.
\end{abstract}

Na tentativa de contar uma história - ou "revelar" a história, visto que ela já existe nos subterrâneos da memória e da própria consciência - o narrador começa a perseguir a voz fantasmagórica pela cidade, pelos espaços públicos da cidade, nos quais pode ouvir pessoas que falam. Na praça, senta-se diante de uma estátua de "feições

\footnotetext{
${ }^{285}$ Calvino, I. "Cibernética e fantasmas. Notas sobre a narrativa como processo combinatório". In: Assunto encerrado. cit., p. 205.

${ }^{286}$ Ceserani, R. Raccontare il postmoderno. cit., p. 171: “a hora é vasta, assim como o espaço, no qual predomina a lei do radicalmente descontínuo, do justaposto e do incompatível".

${ }^{287}$ Tabucchi, A. "Voci portate da qualcosa, impossibile dire cosa". In: Racconti. cit., p. 277. Trad. bras. cit., p. 18: "é impossível pensar em tudo ao mesmo tempo, é preciso analisar as coisas com ordem, mas será que as coisas têm uma ordem? E a que tipo de ordem se refere uma frase como esta: a que tempo, a que momento, a que circunstância? A tudo, pode referir-se a tudo, portanto não adianta pensar nas coisas com ordem, deixe-as vir à sua cabeça do jeito que elas quiserem”.
} 
realistas", pensando que ela talvez possa lhe trazer a voz fugidia, e começa a pensar naquele verão, quando tudo tinha começado:

\begin{abstract}
"Tadeus, ti prego, che cosa devi dirmi? E intanto ripensi a quell'estate, che avevi così accuratamente dimenticato riponendola in una cantina sulla quale avevi posato un pesante coperchio. E ora quel coperchio, come per magia, si è mosso, è slittato aprendo una fessura" ${ }^{288}$.
\end{abstract}

O narrador começa a penetrar nas lembranças do passado e nos dá indícios de um romance que tinha escrito e que provavelmente estava lendo para Isabel, a companheira de Tadeus. Esse romance, após os estranhos acontecimentos daquele verão, é destruído pelo próprio autor. O fato narrado é aparentemente autobiográfico e autorreferencial, pois na nota introdutória ao livro L'Angelo Nero, Tabucchi faz referência a um romance que teria escrito anos atrás e jogado fora e que, por coincidência do acaso, duas páginas desta história teriam "reaparecido" misteriosamente numa gaveta - fato não aleatório, em se tratando de um escritor como Tabucchi, que frequentemente nos dá notícias de seu processo criativo, seja nos próprios contos, como vemos em "Voci portare da qualcosa...", seja nos seus prefácios e notas introdutórias. Importante ressaltar, todavia, que este fato pode ser parte da ficção tabucchiana, pois, como notamos no capítulo anterior, os prefácios e notas do autor constantemente dão indícios falsos sobre a criação de uma narrativa.

Ainda na nota de L'Angelo Nero, Tabucchi menciona o fato de que o "anjo" presente no último conto do livro, "Capodanno", fazia parte dessa história descartada. Este “anjo" reaparece em "Capodanno", encarnado na figura do Capitão Nemo, de Verne, outro intertexto presente na coletânea. A figura do anjo reaparece como uma das imagens maléficas de L'Angelo Nero, já que é ele quem guia o menino em suas descobertas pelos subterrâneos da casa e o ajuda a planejar a vingança contra a família. Assim, a "história de uma história que não existe mais"289 contém e está contida nas

\footnotetext{
${ }^{288}$ Tabucchi, A. "Voci portate da qualcosa, impossibile dire cosa". cit., p. 278. Trad. bras. cit., p. 19: "Tadeus, por favor, o que quer dizer-me? E enquanto isso volta a pensar naquele verão, que tinha tão cuidadosamente esquecido, guardando-o num porão sobre o qual colocara uma pesada tampa. E agora aquela tampa, como que por magia, mexera-se, escorregara, abrindo uma fenda".

${ }^{289} \mathrm{O}$ episódio do romance "não-escrito" é narrado também em um dos fragmentos de I volatili del Beato Angelico, no texto "Storia di una storia che non c'è", em que o autor persegue os rastros dessa história.
} 
histórias da coletânea. É citada na nota introdutória, está presente no conto inicial e retorna no conto final, por meio da figura do "anjo", emoldurando as narrativas do livro.

A presença desse romance "não-escrito" dentro da narrativa e sua relação com os fatos narrados, de qualquer modo, não ficam muito claras ao leitor, que não consegue precisar qual era a relação do narrador com Isabel ${ }^{290}$. O narrador insinua apenas o medo que Isabel tinha de permanecer sozinha na casa sobre o penhasco, onde passava o verão, o que teria feito com que os dois se aproximassem. A narrativa é fragmentada, cheia de fissuras, as partes não se encaixam, como em um quebra-cabeça em que faltam peças.

O narrador tenta preencher essas lacunas por meio das vozes fantasmáticas, trazidas do além. Continua a percorrer a cidade, na expectativa de reencontrar esta voz e a encontra em meio a um grupo de rapazes de um time de futebol, e desta vez, a voz marca um encontro para "il giorno 10 maggio alle ore sei pomeridiane" - dia 10 de maio, às seis horas da tarde - no lugar mais alto da cidade. O narrador se dá conta de que são quase seis horas do dia marcado e se dirige para a torre mais alta da cidade. Quando chega ali, encontra apenas um casal de anciãos, e a única coisa que consegue ouvir da conversa deles são pedaços de frases que não lhe explicam coisa alguma: "è una malattia che oggi si può controllare, è un virus simile all'herpes zoster"291. Depois se calam e descem as escadas, deixando o narrador sozinho e surpreso. Nesse momento começa uma forte chuva e o narrador é tomado por uma vertigem que prende seu olhar e se transforma numa comichão, descendo pelas costas e alcançando suas mãos, que se agarram forte no ferro do parapeito:

\footnotetext{
"Senti la vertigine che ti cattura lo sguardo e che si trasforma in un pizzicore che ti scende lungo la schiena e ti raggiunge le mani che ora si aprono e si chiudono da sole sul ferro del parapetto: ora sai perché Tadeus ti ha chiamato fin lì, non poteva essere che lui a darti un simile appuntamento"292.
}

\footnotetext{
${ }^{290}$ Recentemente, após a morte do escritor, a editora Feltrinelli publicou o romance inédito, Per Isabel, romance em que o protagonista busca encontrar a personagem Isabel, desaparecida em circunstâncias misteriosas. O texto dialoga com os episódios narrados nesse conto de L'Angelo Nero e em Requiem, evidenciando, mais uma vez, a autorreferencialidade e a circularidade da narrativa tabucchiana e de seus personagens.

${ }^{291}$ Tabucchi, A. "Voci portate da qualcosa, impossibile dire cosa". cit., p. 282. Trad. bras. cit., p. 25: "é uma doença que hoje em dia já se pode controlar, é um vírus parecido com o herpes-zoster".

${ }^{292}$ Tabucchi, A. "Voci portate da qualcosa, impossibile dire cosa". cit., p. 282. Trad. bras. cit., p. 25: "Sente a vertigem que prende o seu olhar e que se transforma numa comichão que desce pelas suas costas e alcança suas mãos que agora se abrem e fecham sozinhas no ferro do parapeito: agora você sabe por que Tadeus o chamou ali, só ele poderia marcar um encontro como este".
} 
O narrador é tomado por uma força maligna que o puxa para baixo, e entende porque Tadeus o tinha trazido até ali. Compreensão que, todavia, não se estende ao leitor, que permanece em suspense, sem conseguir precisar exatamente o significado da mensagem, o desnorteamento do narrador, o que o fantasma de Tadeus desejava realmente dizer e que relação tinha com os acontecimentos do passado. A história permanece sem conclusão, como muitas das histórias tabucchianas, e ao invés disso temos a zombaria do fantasma de Tadeus, que parece rir do narrador.

Outra zombaria de Tadeus, semelhante a essa, é narrada em Requiem, quando o narrador-protagonista encontra o fantasma do amigo e lhe pergunta o significado de um bilhete que ele tinha lhe deixado pouco antes de morrer. No bilhete estava escrito: "foi tudo culpa do herpes zoster" ${ }^{\text {293 }}$. Tadeus, quando é visitado pelo protagonista, diz que passou a vida toda fazendo brincadeiras com as pessoas, e que esta teria sido a sua última piada. Analogamente, o narrador do conto de L'Angelo Nero é vítima da mesma brincadeira sarcástica, feita pelo fantasma de Tadeus.

A explicação da misteriosa frase de Tadeus, expressa no bilhete tanto quanto por intermédio do casal de velhos nos é dada, entretanto, por outro personagem de Requiem: o Pintor Copiador que copia um detalhe do quadro de Bosch, As tentações de Santo Antão, justamente o detalhe em que se vê um homem gordo e uma velha que viajam no céu cavalgando um peixe - detalhe que está presente, ainda que de modo alusivo, na conclusão de "Notte, mare o distanza". Diz o copista que o quadro de Santo Antão, antigamente, ficava exposto em um hospital em Lisboa e atraía muitos doentes peregrinos, em busca de cura para seus sofrimentos, em especial, doentes portadores de doenças venéreas e de uma espécie de erisipela epidêmica e cíclica, chamada popularmente de fogo de Santo Antão, uma doença provocada por um vírus, cujo nome cientifico é herpes zoster:

"É um vírus muito estranho, disse o Pintor Copiador, parece que todos o albergamos dentro de nós em estado larvar, mas ele manifesta-se quando as defesas do organismo estão mais fracas, então ataca com virulência, e depois adormece e volta a atacar ciclicamente, olhe, digo-lhe uma coisa, eu acho que o herpes é um pouco como o remorso, fica adormecido dentro de nós e um belo dia acorda e ataca-nos, e depois volta a adormecer porque nós

\footnotetext{
${ }^{293}$ Tabucchi, A. Requiem. cit., p .34. (Grifos do autor).
} 
conseguimos amansá-lo, mas fica sempre dentro de nós, não há nada a fazer contra o remorso" ${ }^{, 294}$.

O vírus é associado, em Requiem, ao remorso, ao sentimento de culpa do protagonista. $\mathrm{O}$ vírus é cíclico, assim como o remorso (e como as referências a Tadeus e Isabel, presentes nas narrativas tabucchianas), evidenciando, assim, que algo em relação ao passado do narrador deve ser revisitado, para poder ser entendido e, finalmente esquecido. A escrita tem o papel, portanto, de retomar estes fatos para tentar dar-lhes uma conclusão.

Todavia, em "Voci portate da qualcosa...", assim como em Requiem, o narrador busca compreender a frase ou o bilhete de Tadeus, mas não encontra nenhuma explicação possível, o encontro com o fantasma do amigo também não revela a história, que permanece incompleta, suspensa. A voz sarcástica de Tadeus deixa subentendida a necessidade de revelar uma verdade que permaneceu muito tempo escondida, e "l'appuntamento falso", o falso encontro, não oferece nenhuma possibilidade de explicação:

\footnotetext{
"Il nesso creato sulla malattia, sul contagio del virus (herpes/Inconscio), nel racconto evidenzia l'impossibilità di dare un senso al messaggio di Tadeus, al passato e/o alla scrittura"295.
}

A obsessão do personagem de "Voci portate da qualcosa..." pela frase incompleta de Tadeus se deve ao sentimento de culpa que carrega em relação ao passado. O remorso está presente não só neste conto, como também em Requiem e em outras narrativas, evidenciando a circularidade dos temas tabucchianos, além da presença de personagens recorrentes, que marcam a inquietude de sua literatura. $\mathrm{O}$ universo tabucchiano é construído, assim, de modo complexo, com mensagens difíceis de decifrar, com personagens à espreita de uma frase ou uma palavra que possam tornar os acontecimentos mais claros; personagens à deriva, que tentam escapar a todo custo do naufrágio eminente.

\footnotetext{
${ }^{294}$ Tabucchi, A. Requiem. cit., p. 68.

${ }^{295}$ Trentini, N. Una scrittura in partita doppia. cit., p. 183: "O nexo criado sobre a doença, sobre o contágio do vírus (herpes/Inconsciente), evidencia, no conto, a impossibilidade de dar um sentido à mensagem de Tadeus, ao passado e/ou à escrita".
} 
O final de "Voci portate da qualcosa..." e a busca pelo significado da frase de Tadeus são marcados pela presença do mal, que por sua vez, configura-se no remorso, no sentimento de culpa, que impelem o narrador a se defrontar com a morte, por meio da presença do fantasma de Tadeus e do aparente desejo - reprimido? - de suicídio.

O jogo combinatório estabelecido no início do conto e a zombaria do final mostram, de acordo com Anna Dolfi, a passagem de uma "positividade lúdica a uma ludicidade inquietante" ${ }^{296}$ - marcada, no texto, pelo uso ambíguo dos sinônimos gioco/scherzo, utilizados pelo autor.

O final do conto e a zombaria do fantasma de Tadeus nos remetem também ao episódio final de Il filo dell'orizzonte, ao riso de Spino, quando este percebe que é impossível descobrir qualquer resposta para a sua investigação. Diante da impossibilidade de conhecer a verdade, Spino se precipita "nel buio" - no escuro - e ri, e o romance se conclui desta forma enigmática.

Tabucchi, ao refletir sobre sua poética, em Autobiografia altrui, pergunta-se, como o faz boa parte da crítica, sobre o significado desta risada, e apresenta duas hipóteses como resposta: a primeira ligada ao humorismo pirandelliano, ao sentimento de contrários que alimenta o drama: "il comico (in realtà per Pirandello l'umorismo) è il rovescio del dramma. Le due cose, opposte e complementari sono le due facce della stessa medaglia" ${ }^{\text {297 }}$. A outra hipótese é de matriz bergsoniana, ligada à ideia do riso como negação.

A propósito do riso como "humor biliar" - a melancolia, de acordo com Pirandello, é um "umore che molti chiamano collera nera" 298 - Tabucchi cita o poema Rir, roer do poeta português Alexandre O'Neill, poeta e amigo pessoal do autor e que, pelo seu humor satírico, provocatório e reflexivo, serve de fonte de inspiração para a criação do personagem Tadeus. O poema se refere justamente a esta passagem do riso ao seu contrário, o pranto, fazendo com que "o homem se veja disforme":

\footnotetext{
"E se fôssemos rir

Rir de tudo, tanto,

Que à força de rir,
}

\footnotetext{
${ }^{296}$ Dolfi, A. Tabucchi, la specularità, il rimorso. cit., p. 183.

${ }^{297}$ Tabucchi, A. Autobiografia altrui. cit., p. 53: "o cômico (na realidade, para Pirandello, o humorismo) é o reverso do drama. As duas coisas, opostas e complementares, são as duas faces da mesma moeda".

${ }^{298}$ Pirandello apud Tabucchi, A. Autobiografia altrui. cit., p. 59, nota: "humor, que muitos chamam cólera negra".
} 
Nos tornássemos pranto,

Pranto colector,

Do que em nós sobeja?

No riso, na dor,

Que o homem se veja.

Se veja disforme,

Se disforme for. (...),299

Alexandre O’Neil inicia sua carreira poética como surrealista e se rebela contra toda forma que aprisiona, desprendendo-se de toda regra e convenção. Sua poesia transita entre a euforia e o desengano, passando por várias fases humorísticas, desde uma ironia sutil até chegar ao humor negro: "o humor, nos seus diversos graus de acidez e nas suas modulações, é a forma de denúncia mais comum em Alexandre O’Neill”300. Na sua poesia é recorrente o prefixo des- com valor de negação, o que parece indicar, muitas vezes, uma ideia de desconstrução da própria poesia, um "des-escrever", uma "des-conversa", como que uma autocrítica que produz a "antipoesia da sua poesia, deixando cada vez mais vir à tona a dor que o riso escondia" ${ }^{, 301}$.

No que se refere à criação do personagem Tadeus, esses traços do humor de O’Neill parecem preservados, seja o humor negro que exala de suas piadas, seja a inquietude de sua figura, o constante vacilar em relação ao engajamento da poesia e do próprio artista. Quanto à escrita propriamente dita, tanto O’Neill na poesia, quanto Tabucchi na narrativa, utilizam procedimentos como o jogo, o trocadilho, a colagem, o recurso ao sonho. Além disso, ambos parecem se valer da ideia pirandelliana do “homem que se vê disforme", presente no poema de O’Neill (citado por Tabucchi) e no humor inquietante do personagem Tadeus.

Como podemos perceber, em L'Angelo Nero, Tabucchi não só estabelece diálogos intertextuais com poemas e poetas que admira, como também se utiliza de dados e características biográficas destes poetas para a escrita narrativa, para a composição da personagem e de seu caráter: Alexandre O'Neill, na criação de Tadeus, e

\footnotetext{
${ }^{299}$ O’Neill apud Tabucchi, A. Autobiografia altrui. cit., pp. 54-55.

${ }^{300}$ Rocha, Clara. Prefácio a Poesias completas1951-1986 de Alexandre O’Neill. In: O’Neill, A. Poesias completas1951-1986. $3^{\mathrm{a}}$. ed. Lisboa: Imprensa Nacona/Casa da Moeda. p. 25.

${ }^{301}$ Rocha, Clara. Prefácio a Poesias completas1951-1986 de Alexandre O’Neil. cit., pp.14-15.
} 
o velho poeta do conto "La trota che guizza fra le pietra mi ricorda la tua vita", que pelas referências e alusões presentes na narrativa nos remetem a Eugenio Montale.

O diálogo intertextual se faz presente mediante as citações alusivas ou explícitas de versos de poetas conhecidos e, em alguns casos, traduzidos por Tabucchi, como Drummond de Andrade e O’Neill, poetas de língua portuguesa. No que toca à língua e à literatura italiana, o poeta homenageado, já por meio do título da coletânea, L'Angelo Nero, é também Eugenio Montale que, segundo o próprio Tabucchi, antes dele, "si è imbattuto in un angelo con le ali nere" ${ }^{\text {302 }}$. O título do livro tabucchiano não corresponde ao título de um dos contos, mas alude ao poema montaliano, como se este fosse uma espécie de moldura, que engloba todos os contos:

"O grande angelo nero
fuligginoso riparami
sotto le tue ali ${ }^{303 "}$,

O "piccolo angelo nero" que resplandece e muda de cor, "difforme e multiforme" ${ }^{304}$, possui, em germe, a dimensão do Mal transubstanciada em formas diversas e é uma das presenças maléficas constantes em L'Angelo Nero. O diálogo que se estabelece com a obra de Montale se dá, também, por meio do tom e da intenção adotados pela coletânea que se aproxima do tom do livro La Bufera, de Montale. Na coletânea de poemas de Montale a guerra é observada em sua dimensão privada, histórica e ontológica de cumprimento do mal cósmico e manifestação do absurdo ${ }^{305}$. Como vimos anteriormente, a guerra também é um dos temas de Sentimento do Mundo, de Drummond. No livro de Tabucchi, esse tema aparece no último conto, "Capodanno" - uma narrativa sobre um garoto que tenta entender um obscuro acontecimento que se relaciona com o massacre de alguns "partigiani" durante a segunda guerra, sendo que seu pai, oficial do exército fascista, talvez estivesse envolvido. No final, o menino opta por envenenar toda a família e os convidados durante um jantar. Neste conto, aliás,

\footnotetext{
${ }^{302}$ Tabucchi, A. Nota a L'Angelo Nero. In. Racconti. cit., p. 269. Trad. bras. cit., p.8: "deparou com um anjo de asas negras".

${ }^{303}$ Montale, E. L'Angelo Nero. In: Tutte le poesie. Org. Giorgio Zampa. Milão: Arnoldo Mondadori Ed., 2012. pp. 378-379: "Oh grande anjo negro/fuliginoso protege-me/sob as suas asas".

${ }^{304}$ Montale, E. L'Angelo Nero. cit., p. 379: "pequeno anjo negro"; "disforme e multiforme".

${ }^{305}$ Romolini, M. "I notturni della coscienza: il montalismo degli angeli neri". In: I "Notturni" di Antonio Tabucchi. cit., p. 127.
} 
temos o anjo da guarda "Duccio", encarnado na figura do Capitão Nemo, que acompanha e guia o menino pelos subterrâneos da casa, em seus sonhos e descobertas.

Assim, o diálogo com Montale se estabelece ao longo de todo o livro por meio da figura do anjo negro, presente no título da coletânea e em alguns dos contos. É interessante citar o conto "La trota che guizza fra le pietre mi ricorda la tua vita" - título que, aliás, alude a outro poema de Montale, La trota nera, presente também em La Bufera - que escapa um pouco do jugo do Mal ao narrar a história de um poeta que vive a sua velhice entre a exaltação dos críticos e uma tendência à reserva ${ }^{306}$, embora este poeta planeje uma vingança póstuma por meio de sua poesia. Neste conto, conseguimos identificar a presença de Montale seja pelas "semelhanças" da biografia do personagem com a do poeta, seja por meio da concentração de alusões e/ou citações de versos montalianos: "la poesia è menzogna, ho mentito per tutta la vita, tutta la scrittura è menzogna, anche le cose più vere" ${ }^{, 307}$.

Alguns dos procedimentos formais adotados por Tabucchi, tais como o "citacionismo" e a "propensão à metaliteratura", conforme Romolini, fazem ecoar a poética inaugurada por Montale em Satura, numa clara alusão à tendência a autocitação paródica da última poesia montaliana, que "rovescia dal recto al verso la sua poesia"308. O uso constante de intertextos literários e pictóricos que perpassa a narrativa tabucchiana consiste também em estruturas que evidenciam o intenso diálogo com a tradição italiana, com a poesia e também com outras culturas, como a brasileira e a portuguesa. O autorreferencialismo de L'Angelo Nero, por fim, faz pensar na função de espelho mágico de que fala Calvino em relação à escrita literária ${ }^{309}$, que estabelece um jogo ou uma sobreposição de camadas narrativas no próprio texto, assinalando um desdobramento do autor e uma tentativa de fazer com que sua arte se englobe a si mesma, refletindo-se como num espelho.

\footnotetext{
${ }^{306}$ Romolini, M. "I notturni della coscienza: il montalismo degli angeli neri". In: I "Notturni” di Antonio Tabucchi. cit., p. 124.

${ }^{307}$ Tabucchi, A. "La trota che guizza fra le pietre mi ricorda la tua vita". In: Racconti. cit., p. 333. Trad. Bras. Mário Fondelli. "A truta que pula entre as pedras lembra-me da sua vida". In: Anjo negro. cit., p. 98: "a poesia é mentira, menti por toda a minha vida, toda escrita é mentira, até as coisas mais verdadeiras".

${ }^{308}$ Romolini, M. "I notturni della coscienza: il montalismo degli angeli neri”. cit., p. 124, nota 44: "vira do direito ao avesso a sua poesia".
}

${ }^{309}$ Vide nota 218. 


\subsection{DILEMAS SOBRE O INCIPT}

"De que se formam os nossos poemas? Onde? / Que sonho envenenado lhes responde / se o poeta é um ressentido / e o mais são nuvens?". Carlos Drummond de Andrade.

Como vimos, em alguns dos contos de L'Angelo Nero encontramos procedimentos criativos que são refletidos e tematizados na própria narrativa: "Voci portate da qualcosa...", por exemplo, procura mostrar um mecanismo de criação artística baseado na "arte combinatória", criando uma história a partir de fragmentos de outras histórias, ouvidas por acaso, enquanto o narrador passeia pela cidade. Em "Notte, mare o distanza", temos um narrador consciente das dificuldades de se narrar o passado, que tenta resgatar um acontecimento vivido, mas se dá conta da árdua tarefa que é reconstruir uma história e do quanto a memória pode "falsear" uma lembrança. Ao final, o narrador mostra como a ficção pode "modificar" uma realidade que parece inverossímil e incoerente.

Esses dois contos são, conforme Anna Dolfi, estruturalmente opostos, pois, enquanto no primeiro a ficção nasce a partir de um fragmento do real, no segundo, temos a tentativa de reverter o real através da ficção - a disponibilidade ao possível, própria da literatura, em modificar a irreversibilidade dos fatos ${ }^{310}$. Em maior ou menor medida, todos os contos deste livro lidam com a mistura entre realidade e ficção - o conto "Il batere d'ali..." é uma narrativa ficcional construída a partir de dados da realidade objetiva. "La trota che guizza fra le pietre..." e "Capodanno" são contos que misturam realidade e ficção seja através do fabular poético, seja no universo infantil, mostrando o mundo misturado e inquietante do poeta e da criança.

Já no conto "Staccia buratta", o problema estrutural que se coloca é "por onde começar uma história?" Dilema narrativo não apenas da protagonista do conto, como de tantos outros narradores tabucchianos, que sempre procuram mostrar a dificuldade de

\footnotetext{
${ }^{310}$ Dolfi, A. Tabucchi, la specularità, il rimorso. cit., p. 211 e ss.
} 
iniciar suas histórias ou como elas podem iniciar a partir do nada, de um jogo, de um fragmento de frase.

Para Tabucchi, um incipit é decisivo, porque significa que algo, na cabeça do escritor, chegou a um ponto de maturação e pode se tornar "mineral" ou mesmo "físico". Para o autor, um início é como a primeira pincelada de um quadro, é uma série de imagens, de detalhes e cores que o pintor cultivou durante muito tempo em sua mente ou, ainda, uma "lápide a priori":

\begin{abstract}
"Ogni incipit - rendendo minerale il pensiero di un inizio, potremmo dire la sua essenza platonica - potrebbe essere pensato come una lapide a priori. Di solito, le lapidi sono 'a posteriori'. In letteratura è possibile invertire anche questo ordine e far diventare una lapide un punto di partenza anziché di arrivo" $" 311$.
\end{abstract}

O narrador de "Voci portate da qualcosa...", por exemplo, começa o conto anunciando as regras do jogo ficcional que pretende utilizar para criar sua história - "A volte può prendere il via con un gioco, un piccolo gioco segreto e quasi infantile che solo tu conosci" 312 . O narrador de "Notte, mare o distanza" começa mostrando as dificuldades do processo de retomada da memória de um fato passado:

\begin{abstract}
“Ogni volta, quando immaginava come avrebbero potuto essersi svolti i fatti quella notte, gli arrivava la voce nasale e ironica di Tadeus che scandiva una di quelle sue frasi che volevano dire tutto e niente: perché è un buon viatico. E subito tutto cominciava a prendere corpo e a delinearsi nei contorni..."313.
\end{abstract}

Já a narradora de "Staccia buratta" se vê diante do momento crucial de retomar a história de sua vida, mas não sabe por onde começar a narrá-la:

\footnotetext{
${ }^{311}$ Tabucchi, A. "Gli incipit di Antonio Tabucchi”. Entrevista concedida a Paolo Di Paolo. In: Mosaico Italiano. Inserto della Rivista Comunità Italiana. Ano VIII, n. 99. Rio de Janeiro: Editora Comunità. Abril 2012. pp. 28-29. "Cada incipit - tornando mineral o pensamento de um início, poderíamos dizer, a sua essência platônica - poderia ser pensado como uma lápide a priori. Em geral, as lápides são 'a posteriori'. Na literatura também é possível inverter esta ordem e fazer uma lápide se tornar um ponto de partida ao invés de um ponto de chegada".

${ }^{312}$ Tabucchi, A. "Voci portate da qualcosa, impossibile dire cosa". cit., p. 273. Trad. bras. cit., p. 11: "Às vezes pode começar com uma brincadeira, uma pequena brincadeira secreta e quase infantil que só você conhece".

${ }^{313}$ Tabucchi, A."Notte, mare o distanza". cit. p. 285. Trad. bras. cit., p. 29: "Toda vez que imaginava como poderiam ter ocorrido os fatos naquela noite, chegava até ele a voz fanhosa e irônica de Tadeus, que escandia uma daquelas suas frases que queriam dizer tudo e nada: porque é um bom viático. E logo tudo começava a tomar a forma e a esboçar-se em seus contornos...".
} 


\begin{abstract}
"Era il momento di pensarci, era proprio il momento di pensarci, del resto non aveva altro da fare se non pensarci [...] pensare alla sua storia. Che cosa avrebbe scritto se avesse dovuto scrivere la sua storia? [...] Pensò sei una donna con una storia. Ma come era questa storia? Che cosa avrebbe scritto se avesse dovuto scrivere la sua storia? Il problema era da dove cominciare. Dove comincia una storia? $?^{314,}$
\end{abstract}

No trecho acima, podemos perceber que a problemática da criação e estruturação da narrativa está intimamente ligada ao problema de como começar a história. A história que deve ser narrada é a de uma estudiosa famosa e madura, que após ter passado a vida jogando com os homens que amara, vê-se sozinha e desesperada em um quarto de hotel, diante de um anjo da guarda de aspecto infernal. A narrativa se configura a partir das reflexões da protagonista em relação às escolhas que a conduziram ao momento narrado. Sabendo-se responsável pelo próprio percurso, pelo seu falso sucesso e pela própria solidão, a protagonista sente que o passado bate à sua porta, em forma de rancor e ressentimento, e narrar sua história é um meio de retomar esses sentimentos que a atordoam e, quem sabe assim, conseguir superá-los.

As narrativas de L'Angelo Nero, de acordo com Anna Dolfi, mostram os percursos incongruentes e incertos de vozes narrativas que revelam as inquietações da atordoante busca de uma identidade fragmentada, desdobrada, enquanto parecem oferecer, por meio da própria escrita, uma "resposta, um ressarcimento a uma culpabilidade persecutória". Segundo a estudiosa, a "persistência do senso de culpa", constante não apenas neste livro, mas em vários outros, nasce, por um lado, da "durabilidade do remorso", e, por outro, sobretudo no caso dos fantasmas e figuras maléficas que povoam L'Angelo Nero, da "implacabilidade dos mortos que retornam e pretendem um esclarecimento ou uma conclusão para a sua história"315:

"Tale persistenza del senso di colpa, se da un lato pare nascere dalla duratività del rimorso, dall'altro è legato a una sorta di implacabilità dei

\footnotetext{
${ }^{314}$ Tabucchi, A."Staccia buratta". In: Racconti, cit. p. 299. Trad. Bras. Mário Fondelli."Boi, boi, boi, boi da cara preta...". In: Anjo negro. cit., p. 49: "Era hora de pensar no assunto, já era hora mesmo, por outro lado nada mais tinha a fazer a não ser pensar naquilo [...] pensar na sua história. $\mathrm{O}$ que iria escrever se fosse escrever a sua história? [...] Pensou: você é uma mulher com uma história. O que iria escrever se tivesse que escrever a sua história? O problema era de onde começar. Onde é que uma história começa?". ${ }^{315}$ Dolfi, A. Tabucchi, la specularità, il rimorso. cit., p. 179.
} 
morti che (sub specie femminile e paterna) ritornano, quali/quasi revenants, a pretendere un chiarimento o scioglimento della loro storia”, ${ }^{\text {316. }}$.

Em "Voci portate da qualcosa..." é o ressentimento que guia o protagonista na (re)construção de sua história, mas enquanto neste conto o narrador procura uma "frase ottima per cominciare" - "uma frase ótima para começar" -, em "Staccia buratta", a narradora sabe que as histórias não começam, mas acontecem:

\begin{abstract}
"Pensò che le storie non cominciano, le storie accadono e non hanno un principio. $\mathrm{O}$ almeno quel principio non si vede, sfugge, perché era già iscritto in un altro principio, in un'altra storia, il principio è solo la continuazione di un altro principio ${ }^{317,}$.
\end{abstract}

A escrita funciona como tentativa de libertar esses personagens inquietos, atormentados e aprisionados dos sentimentos que os angustiam. Como prevê o autor em sua nota a L'Angelo Nero, o passado não deixa de agir sobre o presente, mas retorna em forma de "rimpianto", uma espécie de mistura entre saudade e sofrimento:

\begin{abstract}
"Quello che è stato torna, bussa alla nostra porta, petulante, questuante, insinuante. Spesso reca un sorriso sulle labbra, ma non bisogna fidarsi, è un sorriso ingannatore. E intanto noi viviamo, o scriviamo, il che è lo stesso in questa illusione che ci conduce" ${ }^{318}$.
\end{abstract}

A escrita tenta lidar com esses sentimentos, mas nem sempre o ato de escrever e retomar o passado consegue suprimir o "vazio" deixado pelo tempo passado, pelas escolhas (erradas?) feitas e pelos jogos jogados. Assim, a questão de como se começa uma história se resolve, também nesse conto, com um jogo combinatório, com a possibilidade infinita de combinações ditadas pelo acaso, ou pela astúcia de um hábil

\footnotetext{
${ }^{316}$ Dolfi, A. Tabucchi, la specularità, il rimorso. cit., p. 179: "Tal persistência do sentimento de culpa, se de um lado parece nascer da durabilidade do remorso, de outro, está ligado a uma espécie de implacabilidade dos mortos que (sub specie feminino e paterno) retornam, como/ou quase como fantasmas, pretendendo um esclarecimento ou uma conclusão para a sua história".

${ }^{317}$ Tabucchi, A."Staccia buratta". cit. p. 299. Trad. bras. cit., p. 49: "Achou que as histórias não começam, as histórias acontecem e não têm um início. Ou pelo menos não dá para ver aquele início, escapa, porque já estava escrito num outro início, numa outra história, o início não passa da continuação de outro início". ${ }_{318}$ Tabucchi, Nota a L'Angelo Nero. In: Racconti, cit. p. 269. Trad. bras. cit., p. 8: "O que já foi está de volta, bate à nossa porta, petulante, pedinte, insinuante. Às vezes traz um sorriso nos lábios, mas é melhor tomar cuidado, trata-se de um sorriso enganador. E enquanto isto nós vivemos ou escrevemos, o que dá na mesma, nesta ilusão que nos governa".
} 
narrador, que finge não saber por onde começar, mas se diverte combinando possibilidades. Pois, nas palavras de outro narrador, desta vez de Piccoli equivoci senza importanza, para se começar um história basta um "niente": "a volte può cominciare con un niente, una frase perduta in questo vasto mondo pieno di frasi e di oggeti e di volti, 319 .

Esse "niente" pode ser traduzido também pela associação de um "rumor imperceptível" a uma "cor", como mostra o narrador de "Vagabondaggio", conto de 1988, incluído na segunda edição de Il gioco del rovescio:

\begin{abstract}
"A volte cominciava così, con un rumore impercettibile, come una piccola musica; e anche con un colore, una macchia che nasceva dentro gli occhi e si allargava sul paesaggio, e poi invadeva di nuovo gli occhi e da essi passava all'anima: l'indaco, per esempio. L'indaco aveva un suono di oboe, a volte di clarino, nei giorni più felici. Il giallo invece aveva suono di organo" ${ }^{320}$.
\end{abstract}

No trecho acima, o narrador explica não apenas seu processo criativo, mas remete ao processo de escrita que associa cores e sons na poesia do jovem Dino Campana. Tabucchi recorre aqui ao processo anteriormente citado de utilizar a biografia de um autor para a criação narrativa, e tematiza seu próprio processo de escrita ao mostrar o processo de composição poética de Campana. O que se sobressai é, de novo, o constante diálogo intertextual da literatura com sua tradição. O conto também mostra que a literatura é uma arte que engloba a si mesma, procedimento já discutido anteriormente a propósito da "arte combinatória" e das pesquisas de experimentações literárias de Italo Calvino, que servem de modelo e inspiração a Tabucchi.

O dilema do incipit ou de como se começa uma história se revela, ao final, como um "falso" problema, um artifício da escrita, pois como revela Tabucchi na entrevista concedida a Di Paolo citada acima - também publicada no livro Viaggi e altri viaggi, de $2010^{321}$-, cada incipit esconde "secretas magias" e cabe a cada autor encontrar o "ponto de maturação" do qual fazer nascer sua história. O narrador tabucchiano procura

\footnotetext{
${ }^{319}$ Tabucchi, A."Any where out of the world”. In: Racconti, cit. p. 189. "Às vezes pode começar com um nada, uma frase perdida neste vasto mundo cheio de frases e de objetos e de rostos..."

${ }^{320}$ Tabucchi, A."Vagabondaggio". In: Racconti, cit. p. 379. “Às vezes começava assim, com um rumor imperceptível, como uma pequena música; e também com uma cor, uma mancha que nascia dentro dos olhos e se estendia sobre a paisagem, e depois invadia de novo os olhos e deles passava à alma: o índigo, por exemplo. O índigo tinha um som de oboé, às vezes de clarinete, nos dias mais felizes. $\mathrm{O}$ amarelo, ao contrário, tinha som de órgão".

${ }^{321}$ Tabucchi, A. Viaggi e altri viaggi. Org. Paolo Di Paolo. Milão: Feltrinelli, 2010.
} 
mostrar a dificuldade de se contar uma história, de se começar uma narrativa, mas, na verdade, faz deste expediente um processo de escrita, um dos muitos procedimentos literários que constituem sua literatura e que configuram a sua poética.

Assim, o problema de como começar uma história, tanto quanto o jogo ficcional, o "scherzo", a mentira, o acaso, o equívoco - temas que, como vimos, estão constantemente representados na literatura tabucchiana - consiste também em um procedimento criativo que serve à estruturação do conto e à problematização da forma narrativa. 


\section{CONSIDERAÇÕES FINAIS}

Como podemos perceber, com Il gioco del rovescio, Tabucchi dá início à sua poética "dei buchi” e apresenta sua concepção do universo literário como “jogo do reverso". Nesta primeira coletânea de contos, o autor italiano evidencia algumas das questões temáticas e formais que perpassam grande parte de sua obra de ficção. É o caso, por exemplo, da presença perturbante do sonho e a sua consequente evasão da realidade, um dos temas do conto que dá título ao livro, "Il gioco del rovescio". Neste, a presença de tempos simultâneos na narrativa e a percepção do tempo como ruptura das barreiras entre presente, passado e futuro, constituem procedimentos estruturais que acompanharão todo o percurso do escritor.

A frágil distinção entre realidade e ficção também é um dos temas que configuram a poética instaurada por Il gioco del rovescio: os contos "Il gatto dello Cheshire" e "I pomeriggi del sabato", assim como "Il gioco del rovescio" são narrativas em que a presença de fantasmas do passado se impõem aos personagens como realidade, mudando sua percepção do mundo e seu modo de enfrentar a vida. Nesses contos, a presença do tempo da memória se opõe à concepção de um tempo linear e irreversível, que "devora todas as coisas". Os personagens se mostram prisioneiros da saudade e do desejo de revés que os assola e que não lhes permite continuar suas próprias vidas.

Outros temas e estruturas focalizados pela nossa análise estão presentes em "Dolores Ibarruri versa lacrime amare" e "Il Piccolo Gastby", que tratam da convivência de personagens reais e ficcionais na narrativa. A concepção de personagem é particular nestes contos, pois eles são construídos a partir de uma "identidade fictícia" combinada ao gosto pela "troca de papéis", ou seja: Tabucchi lida com um processo de estruturação da subjetividade do personagem que passa pela mediação de outras obras literárias, retomando a "ficção dentro da ficção" de Pirandello assim como a heteronímia de Fernando Pessoa. A intertextualidade se afirma como chave 
interpretativa e como jogo ficcional que estabelece os nexos de sentido e preenche os vazios deixados em aberto pela narrativa.

Já em Piccoli equivoci senza importanza, Tabucchi parodia gêneros literários e se utiliza de modelos de escrita inspirados em grandes escritores da literatura universal - Jorge Luis Borges em "Rebus", Thomas Mann em "I treni che vanno a Madras" para dar forma à sua obra. Reelabora textos pré-existentes, utiliza-se consciente e reflexivamente da montagem e da colagem de outros textos literários, inserindo-os propositalmente em sua narrativa, valendo-se, também, da referência à música e ao cinema para compor estes textos-mosaicos.

Também experimenta uma forma de revisitação pós-moderna da literatura fantástica nos contos "Any where out of the world", "I treni che vanno a Madras", e em "Gli incanti”, que mostra como um ato de vodu e feitiçaria de uma pequena órfã leva a um homicídio involuntário, causado, talvez, por uma trágica brincadeira do destino. A revisitação do universo fantástico está presente também nos contos "Il gatto dello Cheshire" e "I pomeriggi del sabato", de Il gioco del rovescio.

O gênero policial é reelaborado e discutido, por sua vez, em contos como "Rebus" e "Cambio di mano". Neste último, o personagem protagonista trabalha para uma misteriosa causa de um país latino. O leitor sabe que quando o protagonista abrir a porta será morto, mas não consegue saber o motivo. Também L'Angelo Nero possui ecos do "giallo", expresso pela presença da violência policial em "Notte, mare o distanza" e "Il battere d'ali di una farfalla a New York può provocare un tifone a Pechino?".

Como verificamos durante o estudo, esses procedimentos paródicos não são os únicos elementos da pós-modernidade literária presentes na obra tabucchiana. Em relação à técnica narrativa, por exemplo, foi possível verificar que a presença de tempos simultâneos, justapostos, condensados ou coexistentes e a decorrente ruptura das barreiras entre presente, passado e futuro - que se dá em "Any where out ofthe world" e em "Il gioco del rovescio" - faz com que a forma narrativa se desestabilize, postulando, assim, uma literatura da crise das formas convencionais.

Em Piccoli equivoci senza importanza, alguns contos procuram retratar a experiência fugidia da urbanidade. Em "Any where out ofthe world", vimos que a noção 
de sujeito e de identidade não se consolida, uma vez que não existe um narrador unívoco, mas apenas um reflexo de uma consciência estruturante, desdobrada entre um "eu" e um "tu". A variação do foco narrativo complica a percepção do ponto de vista por parte do leitor. Este procedimento é retomado em L'Angelo Nero, no conto "Voci portate da qualcosa, impossibile dire cosa", e de maneira mais complicada em "Notte, mare o distanza".

No que se refere à problemática da criação e estruturação do conto e à descrição de seus processos criativos, Tabucchi se utiliza declaradamente do jogo ficcional, da charada, da brincadeira do acaso ou do destino: "Rebus", "Any where out of the world" e "Piccoli equivoci senza importanza", como vimos, representam bem estas modalidades e escolhas literárias.

Quanto à temática, Piccoli equivoci senza importanza estabelece um diálogo entre a realidade inverossímil e os limites da imaginação, procurando demonstrar como a ficção, em alguns casos, pode parecer mais verossímil que o próprio real. Ao colocar o equívoco como chave interpretativa, Tabucchi trabalha em uma perspectiva metaliterária que incentiva o leitor a refletir sobre sua escrita. Como recurso estilístico, conforme dito anteriormente, o equívoco consiste em um mal-entendido linguístico, um engano que estabelece a ambiguidade no discurso literário, recurso que o escritor utiliza para criar seus jogos narrativos, para compor a vida desencontrada de seus personagens.

É o caso dos personagens de "Piccoli equivoci senza importanza", que devido a um pequeno engano no registro de matrícula para a universidade, são colocados em posições opostas em um tribunal, durante um processo jurídico. O desejo nostálgico do narrador de que tudo pudesse ser simplificado, de retorno a uma condição anterior ao irremediável equívoco, faz com que a poética do revés, instaurada com Il gioco del rovescio, se atualize em novas nuances. Basta pensar no prefácio da segunda edição em que o autor afirma que $I l$ gioco del rovescio nasceu de uma descoberta: "l'essermi accorto un giorno, per le imprevedibili circostanze della vita, che una certa cosa che era 'così', era invece anche in un altro modo" ${ }^{322}$. Esta percepção, ditada pela maravilha e pelo acaso, pelas "imprevisíveis circunstâncias da vida", não deixam de causar certo temor que o impedem de acreditar na ilusão de poder "domesticar" a vida com a escrita.

\footnotetext{
${ }^{322}$ Tabucchi, A. Prefazione alla seconda edizione de Il gioco del rovescio. In: Racconti. cit, p. 9. "ter percebido, um dia, pelas imprevisíveis circunstâncias da vida, que uma certa coisa que era assim, era também de um outro modo".
} 
Já em L’Angelo Nero, Tabucchi evoca alguns períodos da história recente italiana de forma paródica e irônica, trabalhando com a multiplicação das perspectivas e problematizando a experiência histórica contemporânea por meio da expressão literária. O autor procura voltar seu olhar para a condição do homem contemporâneo, sem perder de vista a formalização estética da matéria narrativa e as especificidades do gênero literário. Como vimos, esta problemática é uma constante na obra de Tabucchi desde 1975, quando o autor inicia sua carreira literária, publicando Piazza d'Italia. A reescrita da História se dá por meio de textos literários que tentam falar da História italiana do último século vista de uma perspectiva invertida: a dos rebeldes, dos perseguidos, dos perdedores que observam de "baixo" a realidade que os rodeia e se chocam tragicamente com a perspectiva "alta" daqueles que detém o poder.

L'Angelo Nero é um livro que se destaca dos demais porque discute as várias formas de materialização do Mal no homem e isso se dá através da discussão de questões históricas que são importantes para não só para o autor, como também para os demais escritores de sua geração. Entre estas questões está a do terrorismo no final dos anos 60 na Itália. Por este motivo, quase todos os contos deste livro possuem a violência em estágio embrionário ou latente. É justamente este o diferencial entre L'Angelo Nero e os livros anteriores, Il gioco del rovescio e Piccoli equivoci senza importanza: o acréscimo do "negro" à ideia de mistério. De acordo com Brizio-Skov, à equação tabucchiana "rebus-equívoco-reverso-mistério" que marca os contos do decênio 19811991, período com o qual trabalhamos, acrescentam-se "fantasmas maléficos, consciências ruins, presenças alarmantes" que povoam contos em que os eventos continuam a ser apenas sugeridos, sendo que os motivos e as causas destes eventos permanecem obscuros ou inacessíveis ${ }^{323}$. Assim, a figura do "anjo negro" que perpassa as várias narrativas, estabelece um fio condutor, ao mesmo tempo em que dialoga com outros textos, italianos ou não. É um livro em que a intertextualidade com a poesia é muito fecunda, representada pela poesia de Eugenio Montale, Carlos Drummond de Andrade, Alexandre O’Neill.

No que se refere aos personagens tabucchianos, sobretudo dos contos publicados no período em questão, ainda segundo Flavia Brizio-Skov, eles são obrigados a refletir

\footnotetext{
${ }^{323}$ Brizio-Skov. "Dai racconti a Notturno Indiano: 'gioco del rovescio', rebus, equivoci, mistero, intertestualità e percorsi incongrui”. In: Antonio Tabucchi: navigazioni in un arcipelago narrativo. cit., pp. 85-89.
} 
sobre a impossibilidade de compreender a realidade e a se perguntar "que mundo é este em que vivemos?". Estes personagens frequentemente vacilam entre a incerteza do sentido dos acontecimentos e os equívocos da experiência vivida, pois os fatos narrados os obrigam a questionar e refletir sobre um mundo em que as verdades são variáveis que se combinam infinitamente, impossibilitando o estabelecimento de uma lógica única e coerente.

A narrativa apresenta, assim, uma realidade adversa, que não é possível representar realisticamente, é uma espécie de jogo de contrários, com múltiplas possibilidades de solução. O universo literário é criado como enigma ou equívoco, ou seja, o mundo criado pela narrativa é aquele em que não existe uma ordem, mas sim, tantas ordens possíveis. Consequentemente, o leitor é colocado diante das reticências do narrador, perdendo-se nas várias interpretações possíveis e se sente prisioneiro de uma armadilha tanto quanto os protagonistas. As histórias narradas aparecem como "restos de um naufrágio" e não permitem ao leitor dar uma ordem ao universo criado, ao contrário, desestabilizam qualquer tipo de certeza e obrigam o leitor a refletir sobre um mundo em que os significados e as verdades são múltiplos.

O que podemos perceber a partir destas considerações é que a literatura tabucchiana se pauta sobre a reflexão de si mesma, de suas temáticas e técnicas, é metaliterária e autorreferencial. Como dito anteriormente, Tabucchi é um escritor consciente das estruturas e procedimentos narrativos que utiliza em sua literatura. Além disso, é um autor que percebe a complexidade da realidade que pretende apresentar ao seu leitor. Por esses motivos, sua literatura parece estar em sintonia com as questões colocadas pela contemporaneidade. 


\section{BIBLIOGRAFIA}

\section{OBRAS DE ANTONIOTABUCCHI:}

Piazza d'Italia. Milão: Bompiani, 1975.

Il piccolo naviglio. Milão: Mondadori, 1978.

Il gioco del rovescio. Milão: Il Saggiatore, 1981. (2. ed. acrescida, Feltrinelli, 1988).

Donna di Porto Pim e altre storie. Palermo: Sellerio Editore, 1983.

Notturno Indiano. Palermo: Sellerio, 1984.

Piccoli equivoci senza importanza. Milão: Feltrinelli, 1985.

Il filo dell'orizonte. Milão: Feltrinelli, 1986.

I volatili del Beato Angelico. Palermo: Sellerio, 1987.

I dialoghi mancati. Milão: Feltrinelli, 1988.

Un baule pieno di gente. Milão: Feltrinelli, 1990.

L'angelo nero. Milão: Feltrinelli, 1991.

Requiem. Uma alucinação. Lisboa: Quetzal Editores, 1991.

Requiem. Trad. it. Sergio Vecchio. Milão: Feltrinelli, 1992.

Sogni di sogni. Palermo: Sellerio, 1992.

Sostiene Pereira. Una testimonianza. Milão: Feltrinelli, 1994.

Gli ultimi tre giorni di Fernando Pessoa: un delirio. Palermo: Sellerio, 1994.

La testa perduta di Damasceno Monteiro. Milão: Fertrinelli, 1997.

La gastrite di Platone. Palermo: Sellerio, 1998.

Si sta facendo sempre più tardi. Milão: Feltrinelli, 2001.

Autobiografia altrui. Poetiche a posteriori. Milão: Feltrinelli, 2003.

Tristano Muore. Una vita. Milão: Feltrinelli Editore, 2004.

Racconti. Milão: Feltrinelli, 2005.

L'oca al passo. Milão: Feltrinelli, 2006.

Il tempo invecchia in fretta. Nove storie. Milão: Feltrinelli, 2009.

Viaggi e altri viaggi. Org. Paolo Di Paolo. Milão: Feltrinelli, 2010.

Racconti con figure. Org. Thea Rimini. Palermo: Sellerio, 2011. 
Di tutto resta un poco. Letteratura e cinema. Org. Anna Dolfi. Milão: Feltrinelli, 2013. Per Isabel. Un mandala. Milão: Feltrinelli, 2013.

OBRAS DE ANTONIO TABUCCHI TRADUZIDAS E/OU PUBLICADAS NO BRASIL:

A cabeça perdida de Damasceno Monteiro. Trad. Roberta Barni. Rio de Janeiro: Rocco, 1998.

Afirma Pereira: um testemunho.Trad. Roberta Barni. Rio de Janeiro: Rocco, 1995.

Anjo negro. Trad. Mário Fondelli. Rio de Janeiro: Rocco, 1994.

Está ficando tarde demais: romance em forma de cartas. Trad. Ana Lúcia R. Belardinelli. Rio de Janeiro: Rocco, 2004.

Mulher de Porto Pim. Trad. Rachel Gutiérrez. Rio de Janeiro: Rocco, 1999.

Noturno indiano. Trad. Wander Mello Miranda. Rio de Janeiro: Rocco, 1991.

Requiem. Rio de Janeiro: Rocco, 2001.

Sonhos de sonhos. Trad. Rachel Gutiérrez. Rio de Janeiro: Rocco, 1996.

O tempo envelhece depressa: nove histórias. Trad. Nilson Moulin. São Paulo: Cosac Naify, 2010.

Os três últimos dias de Fernando Pessoa: um delírio. Trad. Roberta Barni. Rio de Janeiro: Rocco, 1996.

Os Voláteis do Beato Angélico. Trad. Ana Lúcia R. Belardinelli. Rio de Janeiro: Rocco, 2003.

Tristano morre. Trad. Gaëtan Martins de Oliveira. Rio de Janeiro: Rocco, 2007.

\section{ENTREVISTAS:}

Entrevista a Antonio Tabucchi, org. Marcello Cella e Elena Pinori. In: http://www.alleo.it/content-97. Acesso em 21/06/2011.

Entrevista a Antonio Tabucchi, org. Elena Torre. In: http://www.mangialibri.com/node/5454 . Acesso em 02/06/2014. 
"Lo zio di Lucca a Singapore". Intervista di Paolo Di Paolo ad Antonio Tabucchi. In: TABUCCHI, A. Viaggi e altri viaggi. Org. Paolo Di Paolo. Milão: Feltrinelli, 2010.

Dietro l'arazzo. Conversazione sulla scrittura. Antonio Tabucchi con Luca Cherici. Roma: Giulio Perrone Editore, 2013.

“Gli incipit di Antonio Tabucchi”. Entrevista concedida a Paolo Di Paolo. In: Mosaico Italiano. Inserto della Rivista Comunità Italiana. Ano VIII, n. 99. Rio de Janeiro: Editora Comunità, abril/2012.

\section{BIBLIOGRAFIA GERAL:}

ADORNO, T. W. "Posição do narrador no romance contemporâneo". In: Notas de Literatura I. Trad. Jorge de Almeida. São Paulo: Duas Cidades/ Editora 34, 2003.

AGAMBEM, G. O que é o contemporâneo e outros ensaios. Trad. Vinicius N. Honesko. Chapecó: Argos, 2009.

AMIGONI, F. Fantasmi nel Novecento. Turim: Bollati Boringhieri Editore, 2004.

AMMIRATTI, M. P., Il vizio di scrivere. Letture su Busi, De Carlo, Del Giudice, Pazzi, Tabucchi e Tondelli. Soveria Mannelli: Rubbettino Editore, 1991.

ANDRADE, C. I. N. B. "Em busca da individualidade perdida". In: Revista Insieme. Revista da APIESP. Associação de Professores de Italiano do Estado de São Paulo. São Paulo, 2002, n. 9. pp. 89-96.

“Flâneurs em Lisboa: Pessoa, Saramago e Tabucchi”. In: Visões poéticas do espaço. Ensaios. Org. Patricia Peterle et alli. Assis: FLC/UNESP Publicações, 2008. pp. 87-100.

"Releituras da história em $O$ ano da morte de Ricardo Reis, de José Saramago e Sostiene Pereira, de Antonio Tabucchi”. In: Revista de Literatura, História e Memória. Literatura e Cultura na América Latina. Cascavel: UNIOESTE, vol.5, n. 5, 2009. pp. 291-299.

"Sostiene Pereira: a denúncia de um herói sem qualidades". In: TriceVersa.

Revista do Centro Ítalo-Luso-Brasileiro de Estudos Linguísticos e Culturais. Assis, v.3, n.1, maio-out. 2009. (Disponível em: www.assis.unesp.br/cilbelc/triceversa). 
"Um passeio pelos bosques ficcionais de Antonio Tabucchi”. In: Revista Rascunhos Culturais. Coxim: UFMS. v.3, n.6. jul/dez. 2012. pp.13-28. (Disponível em: http://revistarascunhos.sites.ufms.br/files/2013/04/6ed_artigo_1.pdf).

ÂNGELO, A. P. “Tradição e transgressão no conto policial de Jorge Luis Borges”. Tese apresentada ao Centro de Comunicação e Expressão da Universidade Federal de Santa Catariana, 2006.

ARÊAS, Vilma. "Dois romances da experiência”. In: Revista Via Atlântica. São Paulo: USP/FFLCH/DLCV, n. 3, dez, 1999. pp. 193-202. (Disponível em: http://www.revistas.usp.br/viaatlantica/issue/view/4172).

ASOR ROSA, Alberto. “Il 'dritto' e il 'rovescio' della vita (Antonio Tabucchi)”. In: Novecento primo, secondo e terzo. Milão: Sansoni, 2004.

AUERBACH, Erich. Mimesis. A representação da realidade na literatura ocidental. $5^{\mathrm{a}}$. ed. São Paulo: Perspectiva, 2004.

BARNI, Roberta et alli. "Traduções de textos de Antonio Tabucchi”. In: Revista de Italianística. Departamento de Letras Modernas. Faculdade de Filosofia, Letras e Ciências Humanas da Universidade de São Paulo, v.2, n. 2, jul/1994.

BAKHTIN, M. M. Problemas da poética de Dostoiéviski. 5a. ed. Trad. Paulo Bezerra. Rio de Janeiro: Forense Universitária, 2010.

BAUMAN, Z. Modernidade Líquida. Trad. Plínio Dentzien. Rio de Janeiro: Jorge Zahar Ed., 2001. O mal-estar da pós-modernidade. Rio de Janeiro: Jorge Zahar, 1998.

BENJAMIN, Walter. "O narrador. Considerações sobre a obra de Nikolai Leskov". In: Magia e técnica. Arte e politica. Ensaios sobre literatura e história da cultura. Trad. Sergio Paulo Rouanet. 7ª ed. São Paulo: Ed. Brasiliense, 1994. (Obras escolhidas, vol.1).

“Sobre alguns temas em Baudelaire". In: Charles Baudelaire: um lírico no auge do capitalismo. Trad. José C. M. Barbosa e Hemerson A. Baptista. São Paulo: Editora Brasiliense, 1989. (Obras escolhidas, v. 3).

BERNARDINI, A. F. "Um baú cheio de Pessoas. Escritos sobre Fernando Pessoa de Antonio Tabucchi". In: Revista Via Atlântica. São Paulo: USP/FFLCH/DLCV, n. 5, 2002. (Disponível em: http://www.revistas.usp.br/viaatlantica/issue/view/4172).

BERARDINELLI, Alfonso. “L'incontro con la realtà”. In: Il romanzo, vol.II, Le forme, Org. F. Moretti. Turim: Einaudi, 2002. 
"Classici del romazo europeo: da Stendhal a Kafka." In: Serafino. Cadernos de Pós. Programa de Pós Graduação em Língua e Literatura Italiana do Departamento de Letras Modernas. São Paulo, FFLCH /USP, 2006, n.1.

"Trasformazioni dell'idea di letteratura nel corso del decennio '70". In: Il critico senza mestiere. Scritti sulla letteratura oggi. Milão: Il Saggiatore, 1983.

"La fine del postmoderno". In: Revista de Italianística. X-XI. Departamento

de Letras Modernas. Faculdade de Filosofia, Letras e Ciências Humanas da Universidade de São Paulo, 2005.

Da poesia à prosa. Org. M. Betânia Amoroso. Trad. Mauricio Santana Dias. São Paulo: Cosac Naify, 2007.

Não incentivem o romance e outros ensaios. Trad. Doris N. Cavallari, Francisco Degani, Patricia de Cia. São Paulo: Nova Alexandria/Humanitas, 2007.

"Calvino moralista ou como permanecer são depois do fim do mundo". Trad.

Maria Betânia Amoroso. In: Revista Novos Estudos CEBRAP, n.54, jul. 1999. pp. 97113.

BIASIN, G. P. "Altri cibi, altre istanze”. In: Le periferie della letteratura. Da Verga a Tabucchi. Ravenna: Longo Ediitore, 1997. pp.131-146.

BRIZIO-SKOV, Flavia. 'Dai racconti a Notturno Indiano: 'gioco del rovescio', rebus, equivoci, mistero, intertestualità e percorsi incongrui". "Requiem: fantastico o postmoderno?" In: Antonio Tabucchi: navigazioni in un arcipelago narrativo. Cosenza: Pellegrini Editore, 2002. pp. 81-98/99-126.

BORGES, J. L. Cinco visões pessoais. $3^{\mathrm{a}}$. ed. Trad. Maria Rosinda R. da Silva. Brasília: Editora UnB, 1996.

Ficções (1944).Trad. Davi Arrigucci Jr. São Paulo: Companhia das Letras, 2007.

BUTOR, Michel. "O uso dos pronomes pessoais no romance". In: Repertório. Trad. Leyla Perrone- Moisés. São Paulo: Perspectiva, 1974.

CALVINO, Italo. Lezioni americane. Sei proposte per il nuovo millennio. Milão: Arnoldo Mondadori Editore, 1993.

Una pietra sopra. Discorsi di letteratura e società. Turim: Einaudi, 1980. Assunto encerrado. Discursos sobre literatura e sociedade. Trad. Roberta Barni. São Paulo: Companhia das Letras, 2009.

CANDIDO, Antonio et alli. A personagem de ficção. São Paulo: Perspectiva, 1987. 
CESERANI, Remo. Raccontare il postmoderno. Turim: Bollati Boringhieri, 1997.

"Qualche considerazione sulla modernità liquida". In: La modernità letteraria. Pisa/Roma: Fabrizio Serra Editore, 2010.

Il Fantastico. Bolonha: Il Mulino, 1996.

e De Federicis, L. Il materiale e l'immaginario. Laboratorio di analisi dei testi e di lavoro critico. Vol. 9. Turim: Loesher Editore, 1990.

CHAMISSO, A. A história maravilhosa de Peter Schlemihl. Trad. Marcus Vinicius Mazzari. São Paulo: Estação Liberdade, 1989.

CORTI, Maria. "Reale e realismi”. In. Letteratura italiana del novecento. Bilancio di un secolo. Org. Alberto Asor Rosa. Turim: Einaudi, 2000.

DI PAOLO, Paolo. “Gli incipit di Antonio Tabucchi”. In: Mosaico Italiano. Inserto della Rivista Comunità Italiana. Rio de Janeiro: Editora Comunità. Ano VIII. n. 99, abril, 2012.

DOLFI, Anna. Gli oggetti e il tempo della saudade. Le storie inafferrabili di Antonio Tabucchi. Firenze: Le Lettere, 2010.

Tabucchi: la specularità, il rimorso. Roma: Bulzoni Editore, 2006.

ECO, Umberto. Pós-escrito a $\mathrm{O}$ nome da rosa. Trad. Letizia Zini Antunes e Álvaro Lorencini. Rio de Janeiro: Nova Fronteira, 1985.

Seis passeios pelos bosques da ficção. Trad. Hildegard Feist. São Paulo: Companhia das Letras, 1994.

FERRARO, Bruno. Introduzione e analise di Sostiene Pereira. In: TABUCCHI, A. Sostiene Pereira.Turim: Loescher Editore,1995.

FOUCAULT, Michel. As palavras e as coisas. Uma arqueologia das ciências humanas. Trad. Salma T. Muchail. São Paulo: Martins Fontes, 2002.

FRIEDMAN, Norman. "O ponto de vista na ficção. O desenvolvimento de um conceito crítico". Trad. Fabio Fonseca de Melo. In: Revista Usp. São Paulo, n. 53. pp. 166-182. Mar/mai 2002. (Disponível em: http://www.usp.br/revistausp/53/15-norman-2.pdf)

GUINZBURG, Carlo. Olhos de madeira. Nove reflexões sobre a distância. Trad. Eduardo Brandão. São Paulo: Companhia das Letras, 2001.

HARVEY, David. Condição pós-moderna: uma pesquisa sobre as origens da mudança cultural. Trad. Adail U. Sobral e Maria Stela Gonçalves. São Paulo: Ed. Loyola, 1992. 
HOSSNE, A. Saad. "Degradação e acumulação: considerações sobre algumas obras de Luiz Ruffato". In: HARRISON, M. I. (Org.) Uma cidade em camadas: ensaios sobre o romance Eles eram muitos cavalos de Luiz Ruffato. Editora Horizonte, 2007.

HUTCHEON, Linda. Poética do Pós-Modernismo: história, teoria, ficção. Trad. Ricardo Cruz. Rio de Janeiro: Imago Ed. 1991.

JANSEN, Monica. Il dibattito sul postmoderno in Italia. In bilico tra dialettica e ambiguità. Firenze: Franco Cesati Editore, 2002.

"Tabucchi: molteplicità e rovescio". In: Piccole finzioni con importanza.

Valori della narrativa italiana contemporanea. Org. Nathalie Roelens e Inge Lanslots. Ravenna: Longo Editore, 1991.

KLOPP, Charles. "Terrorismo e anni di piombo nella narrativa di Antonio Tabucchi”. Atas do Colóquio Littérature et "temps des révoltes" (Italie, 1967-1980) : 27 a 29 de novembro de 2008. (Disponível em: http://colloque-temps-revoltes.enslyon.fr/IMG/pdf/LTR_16_Klopp.pdf)

LA PORTA, Filippo. “Gli ultimi vent'anni: nuovi romanzi per nuovi lettori”. In: Manuale di letteratura italiana: Storia per generi e problemi. Dall'Unità d'Italia alla fine del Novecento. Vol. 4. Turim: Bollati-Boringhieri, 1996.

La nuova narrativa italiana. Travestimenti e stili di fine secolo. Turim: Bollati Boringhieri, 1999.

LEOPARDI, Giacomo. "Diálogo de um vendedor de almanaques e de um passante". Trad. Sebastião Uchoa Leite. In: "Leopardi: Diálogos sobre a morte e a vida". Revista Remate de Males. Território da Tradução. IEL/Unicamp. V. 4. 1984. (Disponível em: http://www.iel.unicamp.br/revista/index.php/remate/article/view/2799)

LUPERINI, Romano. La fine del postmoderno. Nápoles: Guida Editore, 2005. MACHADO, A. e FRITOLI, L. "Crime e autoria: Poe e Tabucchi”. In: Fragmentos. n. 33. Florianópolis, jul-dez. 2007. pp. 355-369. (Disponível em: https://periodicos.ufsc.br/index.php/fragmentos/article/download/8691/8020).

MANACORDA, Giuliano. La letteratura italiana d'oggi. 1965-1985. Roma: Editori Riuniti, 1987.

MANGANELLI, Giorgio. La letteratura come menzogna. Milão: Adelphi Ed., 1985.

MANN, Thomas. "Chamisso". In: CHAMISSO, A. A história maravilhosa de Peter Schlemihl. Trad. Marcus Vinicius Mazzari. São Paulo: Estação Liberdade, 1989. 
MAURI, Paolo. “I fantasmi di Tabucchi”. In: L'opera imminente. Turim: Einaudi, 1998. pp.167-175.

MCLAUGHLIN, Martin. "Intertestualità e struttura in Tabucchi: da Il gioco del rovescio a Sostiene Pereira". In: PELLEGRINI, F. e TARANTINO, E. (Org.) Il romanzo contemporaneo: voci italiane. Leicester: Troubador Publishing Ltd., 2006. pp. $29-42$.

MONTALE, Eugenio. Poesias. Trad. Geraldo Holanda Cavalcanti. Rio de Janeiro/São Paulo: Ed. Record. 1997. La bufera e altro. $5^{\text {a }}$. ed. Milão: Arnoldo Mondadori Ed., 1970. Tutte le poesie. Org. Giorgio Zampa. Milão: Arnoldo Mondadori Ed., 2012. NUNES, Benedito. O tempo na narrativa. São Paulo: Ática, 1988.

OLIVEIRA, V. L. "Requiem de Antonio Tabucchi: a voz, o canto, a língua da memória e do luto". In: Revista Insieme. Revista da APIESP. Associação de Professores de Italiano do Estado de São Paulo. São Paulo, 2002, n. 9. pp.77-87.

O’NEILL, Alexandre. Poesias completas 1951/1986. $3^{\circ}$. ed. Lisboa: Imprensa Nacional/Casa da Moeda.

PALMIERI, Giovanni. "Per una volatile leggerezza: il 'lato manco' di Antonio Tabucchi”. In: Piccole finzioni con importanza. Valori della narrativa italiana contemporanea. Org. Nathalie Roelens e Inge Lanslots. Ravenna: Longo Editore, 1991. pp. 125-136.

PARISI, Anna e FALIERE, Elena T. “Antonio Tabucchi: progettualità e dissoluzione delle tracce". Revista Insieme. Revista da APIESP. Associação de Professores de Italiano do Estado de São Paulo. São Paulo, 2001, n. 8. Pp. 21-26.

PASOLINI, Pier Paolo. "Il romanzo delle stragi”. Saggi sulla politica e sulla società. Org. Walter Siti e Silvia De Laude. Milão: Arnoldo Mondadori, 1999.

PAZ, Octavio. Os filhos do barro. Do romantismo à vanguarda. Trad. Olga Savary. Rio de Janeiro: Nova Fronteira, 1982.

PESSOA, Fernando. O livro do desassossego. São Paulo: Brasiliense, 1995.

Il libro dell'inquietudine. Di Bernardo Soares. $17^{\circ}$. ed. Trad. it. Antonio Tabucchi e Maria J. Lancastre. Milão: Feltrinelli, 2013.

Il poeta è un fingitore. Duecento citazioni scelte da Antonio Tabucchi. $17^{\circ}$. ed. Trad. it. Antonio Tabucchi. Milão: Feltrinelli, 2013. 
PETERLE, Patricia. "I viaggi di carta tabucchiani”. In: Mosaico Italiano. Inserto della Rivista Comunità Italiana. Rio de Janeiro: Editora Comunità. Ano VII, n. 84, dezembro, 2010.

PETRONIO, Giuseppe. Sulle tracce del giallo. Roma: Gamberetti Editrice, 2000.

PIAZZA, Isotta. "Play within the play. Alcuni esempi di personaggi-lettori nella narrativa di Antonio Tabucchi”. In: Revista Campi Immaginabili. Il personaggio-lettore e l'arte narrativa. Soveria Mannelli: Rubbettino. n. 30/31, dez. 2004.

PIGLIA, Ricardo. “Teses sobre o conto”. In: Formas breves. Trad. José Marcos Mariani de Macedo. São Paulo: Companhia das Letras, 2004.

O laboratório do escritor. Trad. Josely V. Baptista. São Paulo: Iluminuras, 1994.

O último leitor. Trad. Heloisa Jahn. São Paulo: Companhia das Letras, 2006.

PINTO, Julio Pimentel. Uma memória do mundo: ficção, memória e história em J. L. Borges. São Paulo: Estação Liberdade/Fapesp, 1998.

“A literatura do desassossego". In: EntreLivros. Ano 2, No.15. São Paulo: Ediouro, julho de 2006.

PIRANDELLO L., L' umorismo. Org. Maria Argenziano. Roma: Newton, 1993.

O Humorismo. In: Do teatro no teatro. Org. J. Guinsburg. São Paulo: Perspectiva, 1999.

PONTIERI, Regina. "Onde foi parar o sujeito? - Experiências da subjetividade na ficção do século XX." In: Revista Literatura e Sociedade. São Paulo: USP/FFLCH/DTLLC, n. 14, 2012. (Disponível em: http://dtllc.fflch.usp.br/node/157). RIFATERRE, Michel. "A ilusão referencial”. In: Literatura e realidade (que é o realismo?). Lisboa: Publicações Dom Quixote, 1984.

ROMOLINI, Marica. "I notturni della coscienza: il montalismo degli angeli neri”. In: I "Notturni" di Antonio Tabucchi. Atti di seminario. Firenze, 12-13 maggio 2008. Roma: Bulzoni Editore, 2008. pp.119-130.

RORATO, Laura e STORCHI, Simona. (Org.) Da Calvino agli ipertesti. Prospettive della postmodernità nella letteratura italiana. Firenze: Franco Cesati Editore, 2002.

SANTIAGO, Santiago. “O narrador pós-moderno”. In: Nas malhas da letra. São Paulo: Companhia das Letras, 1989.

SARLO, Beatriz. Tempo passado: cultura da memória e guinada subjetiva. Trad. Rosa Freire d'Aguiar. São Paulo: Companhia das Letras/Belo Horizonte: UFMG. 2007. 
SCARPATI, Claudio. Invito alla lettura di Montale. $5^{\circ}$. ed. Milão: Mursia Ed., 1988.

SPAGNOLETTI, Giacinto. Storia della Letteratura Italiana del Novecento. Roma: Newton, 1994.

SPUNTA, Marina. "Voci senza corpo: postmoderno e oralità in Tabucchi, Magris, Duranti e De Luca”. In: RORATO, Laura e STORCHI, Simona .(Org.) Da Calvino agli ipertesti. Prospettive della postmodernità nella letteratura italiana. Firenze: Franco Cesati Editore, 2002.

SEGRE, Cesare. "Per un bilancio del Novecento". "La congiura degli onesti nel Portogallo di Monteiro”. In: Tempo di bilanci. La fine del Novecento. Turim: Einaudi, 2005. pp. 3-56; 148-150.

STORCHI, Simona. "Sogni di sogni di Antonio Tabucchi: strategie della metanarrazione tra tradizione e postmoderno". In: RORATO, Laura e (Org.) Da Calvino agli ipertesti. Prospettive della postmodernità nella letteratura italiana. Firenze: Franco Cesati Editore, 2002. pp. 157-167.

TABUCCHI, A. Pessoana mínima: escritos sobre Fernando Pessoa. Lisboa: Imprensa Nacional/Casa da Moeda, 1984.

As tentações. Um pintor: Hieronymus Bosch. Um escritor: Antonio Tabucchi.

Org. José Luís Porfírio. Trad. Maria da Piedade Ferreira. Lisboa: Quetzal Editores, 1989.

"Uma conversa no Outono de 1935". In: Brito, J. J. Uma conversa no outono de 1935. Lisboa: Imprensa Nacional/Casa da Moeda, 1985.

"Bernardo Soares, uomo inquieto e insonne". In: Un baule pieno di gente. Milão: Feltrinelli, 1990.

“Catullo e il Cardellino". In: MicroMega. Roma: Gruppo Editoriale L'Espresso, n.5-2012.

"Dialogo fra un romanziere e un venditore di almanacchi". In: Corriere della sera, 24/07/1994.

"I cambi di stagione della letteratura". In: Corriere della sera, 15/01/1998.

"Il mio segreto è fissare il muro". In: La Repubblica, 01/04/2012.

"Il monolocale del racconto". In: Supplemento Alfabeta. n.84. maio/1986. p.

XII.

“Incubi”. In: L'Unità, 08/12/2001. 
“O fio do desassossego". Trad. Sergio Molina. In: Caderno Mais! Folha de São Paulo, 9/9/2001.

“Osservando il Novecento". In: MicroMega. Roma: Gruppo Editoriale L'Espresso, n.1-1999.

"Un fiammifero minerva". In: MicroMega. Roma: Gruppo Editoriale L'Espresso, n.2-1997.

TANI, Stefano. Il romanzo di ritorno. Dal romanzo medio degli anni sessanta alla giovane narrativa degli anni ottanta. Milão: Gruppo Ugo Mursia Editore, 1990.

TRENTINI, Nives. Una scrittura in partita doppia. Tabucchi fra romanzo e racconto. Roma: Bulzoni Editore, 2003.

TODOROV, Tzvetan. "Tipologia do romance policial”. In: Poética da prosa. Trad. Claudia Berliner. São Paulo: Martins Fontes, 2003

VARGAS LLOSA, Mario. "Herói sem qualidades". In: A verdade das mentiras. $3^{\mathrm{a}}$. ed. Trad. Cordelia Magalhães. São Paulo: Arx, 2007.

V.V.A.A. Antonio Tabucchi, la scrittura e l'impegno. In: MicroMega. Roma: Gruppo Editoriale L'Espresso, n.5-2012.

V.V.A.A. I "Notturni" di Antonio Tabucchi. Atti di seminario. Firenze, 12-13 maggio 2008. Roma: Bulzoni Editore, 2008.

V.V.A.A. L'ultimo viaggio di Antonio Tabucchi. Mosaico Italiano. Inserto della Rivista Comunità Italiana. Rio de Janeiro: Editora Comunità. Ano VIII, n. 102, julho, 2012. 